\title{
Oddziaływanie ekstraktów roślinnych na drobnoustroje
}

\section{Anna Krzepitko Monika Kordowska-Wiater Bożena Sosnowska Monika Pytka}

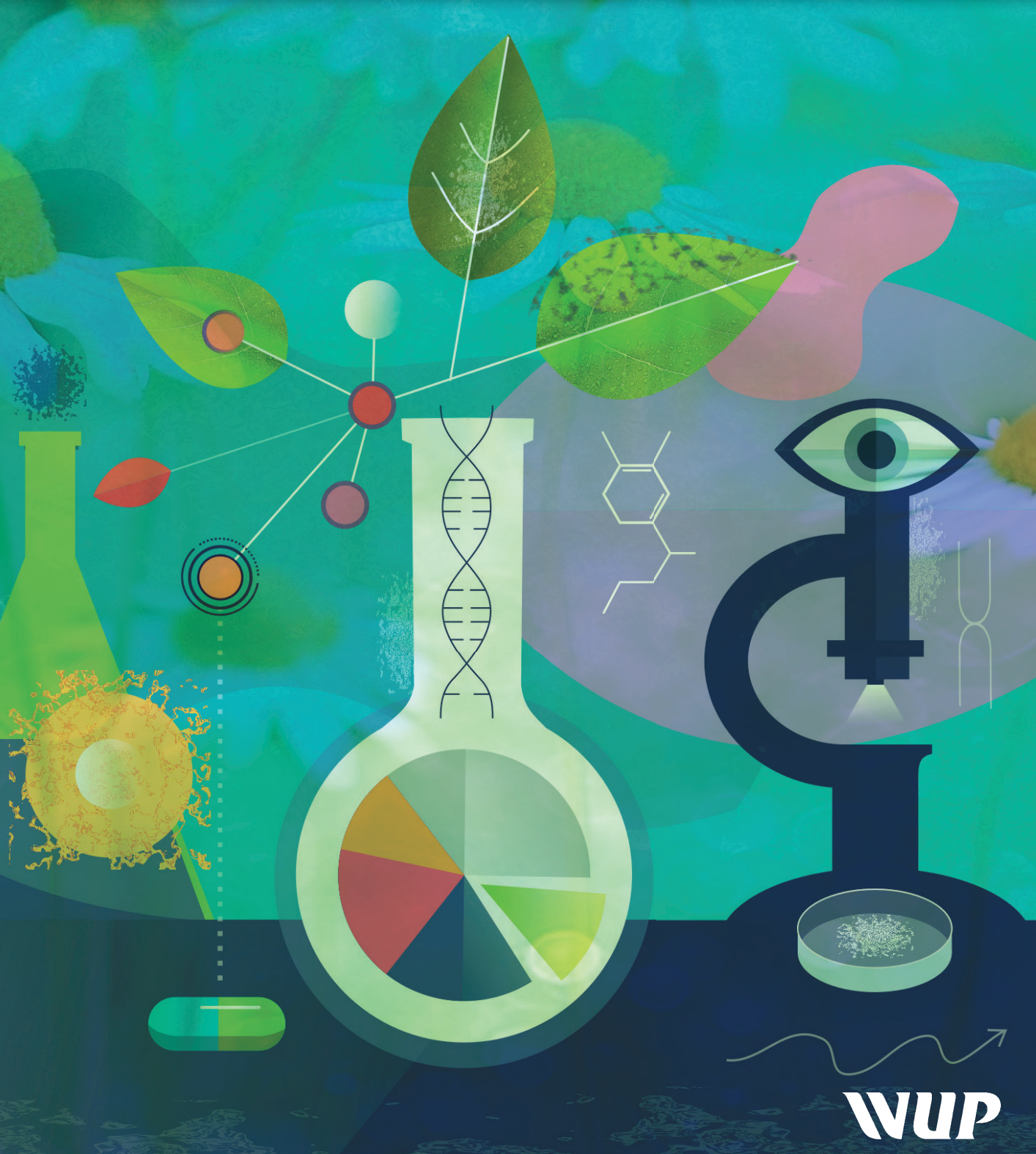




\section{Oddziaływanie ekstraktów roślinnych na drobnoustroje}





\title{
Oddziaływanie ekstraktów roślinnych na drobnoustroje
}

\author{
Anna Krzepiłko \\ Monika Kordowska-Wiater \\ Bożena Sosnowska \\ Monika Pytka
}

Wydawnictwo Uniwersytetu Przyrodniczego w Lublinie 


\title{
Recenzenci
}

prof. dr hab. Bogdan Kędzia

prof. dr hab. Teresa Urbanik-Sypniewska

\author{
Opracowanie redakcyjne \\ Renata Zelik
}

\author{
Skład i łamanie \\ Jacek Pałyszka \\ Projekt okładki \\ Anna Kowalczyk
}

\begin{abstract}
prawolubni
Książka, którą nabyłeś, jest dziełem twórcy i wydawcy. Prosimy, abyś przestrzegał praw, jakie im przysługują. Jej zawartość możesz udostępnić nieodpłatnie osobom bliskim lub osobiście znanym. Ale nie publikuj jej w internecie. Jeśli cytujesz jej fragmenty, nie zmieniaj ich treści i koniecznie zaznacz, czyje to dzieło. A kopiując jej część, rób to jedynie na użytek osobisty. Szanujmy cudzą własność i prawo. Więcej na www.legalnakultura.pl.
\end{abstract}

Polska Izba Książki

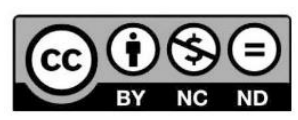

Ten utwór jest dostępny na licencji Creative Commons Uznanie autorstwa -

Użycie niekomercyjne - Bez utworów zależnych 4.0 Międzynarodowe.

\section{ISBN 978-83-7259-325-2 on-line}

DOI: $10.24326 /$ mon.2020.4

\author{
Wydawnictwo Uniwersytetu Przyrodniczego w Lublinie \\ ul. Akademicka 15, 20-950 Lublin \\ www.wydawnictwo.up.lublin.pl
}

Ark. wyd. 8,9 


\section{Spis treści}

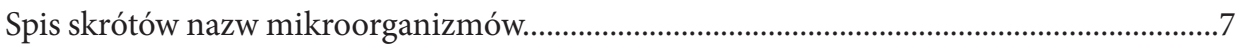

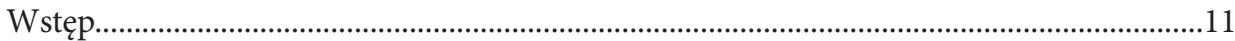

Najczęściej stosowane metody do oceny aktywności przeciwdrobnoustrojowej

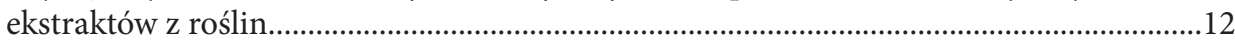

Metody dyfuzyjne..............................................................................................................

Metoda krążkowo-dyfuzyjna.........................................................................................12

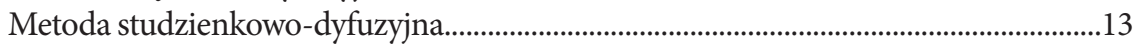

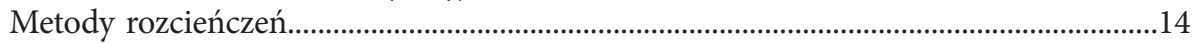

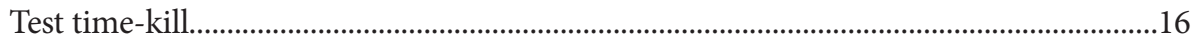

Oznaczanie kiełkowania zarodników grzybów............................................................16

Hodowla na podłożu z dodatkiem substancji przeciwdrobnoustrojowej.......................17

Bioautografia połączona $\mathrm{z}$ chromatografią cienkowarstwową.......................................18

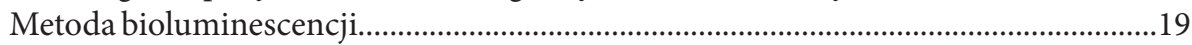

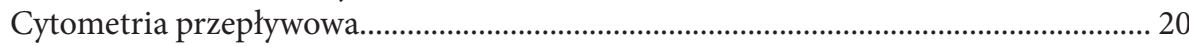

Przygotowanie materiału roślinnego do badań właściwości

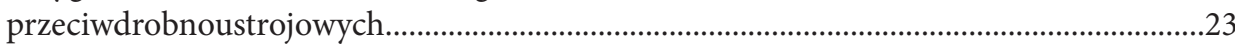

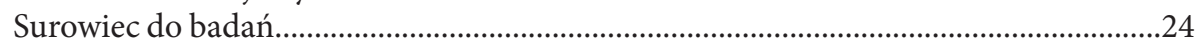

Wstępne przygotowanie surowca roślinnego........................................................25

Metody wyodrębniania związków bioaktywnych z roślin w badaniach

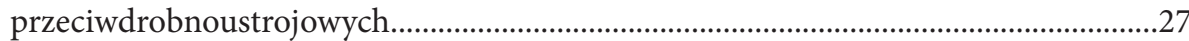

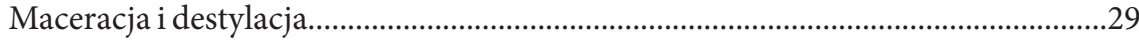

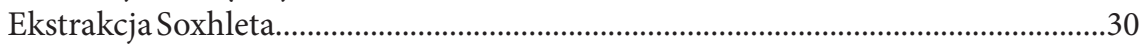

Nowoczesne techniki ekstrakcji substancji z roślin...........................................................33

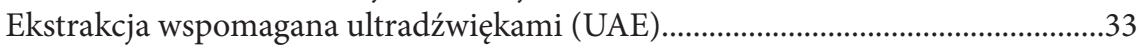

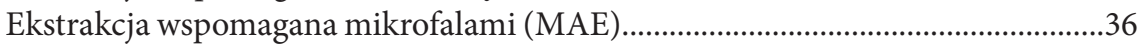

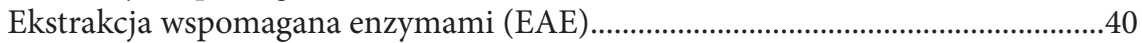

Ekstrakcja cieczą pod ciśnieniem (PLE - pressurized liquid extraction)..................40

Ekstrakcja płynem w stanie nadkrytycznym

(SFE - supercritical fluid extraction) ............................................................................42

Metody standaryzacji ekstraktów roślinnych stosowane w badaniach

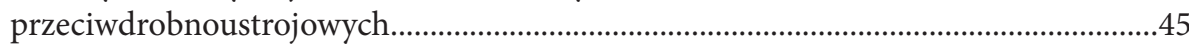

Substancje aktywne ekstraktów roślinnych i ich wpływ na drobnoustroje..........................50 
Grupy metabolitów wtórnych o działaniu przeciwdrobnoustrojowym

Funkcje w roślinach oraz działanie przeciwdrobnoustrojowe wybranych

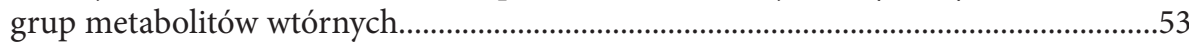

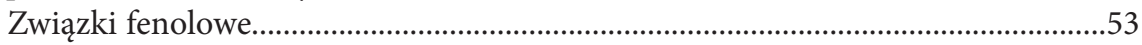

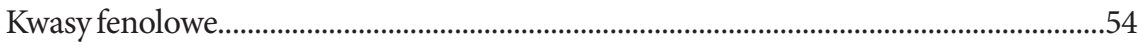

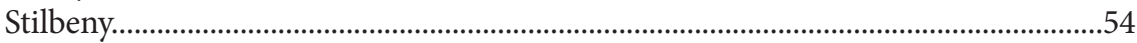

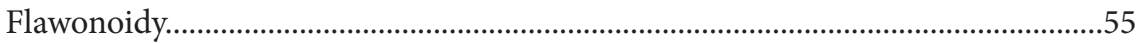

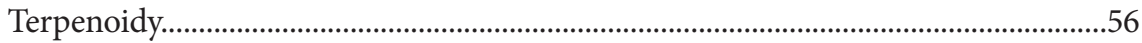

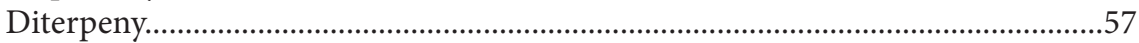

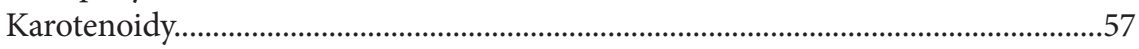

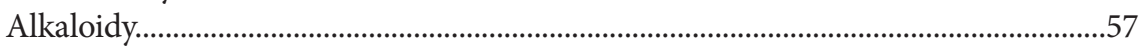

Związki zawierające siarkę..........................................................................................5

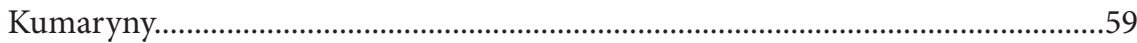

Fitosterole

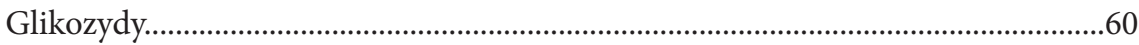

Wpływ ekstraktów roślinnych na chorobotwórcze grzyby drożdżoidalne...............................61

Wpływ ekstraktów roślinnych na chorobotwórcze grzyby pleśniowe...................................65

Przykłady działania ekstraktów roślinnych i olejków eterycznych na grzyby

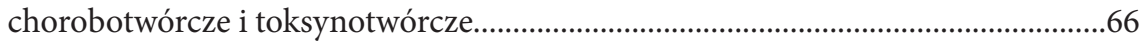

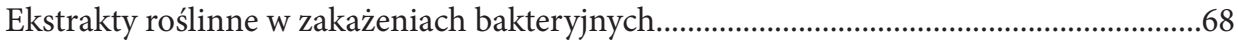

Oddziaływania ekstraktów roślinnych na drobnoustroje probiotyczne................................76

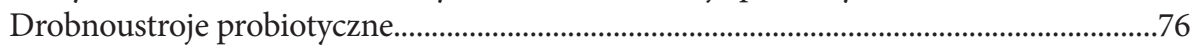

Działanie preparatów roślinnych na probiotyczne kultury bakterii

fermentacji mlekowej....................................................................................................79

Działanie preparatów roślinnych na probiotyczne drożdże

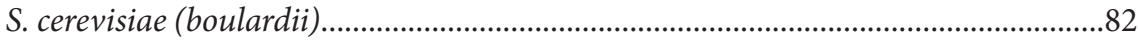

Zastosowanie ekstraktów roślinnych w ochronie roślin przed chorobotwórczymi

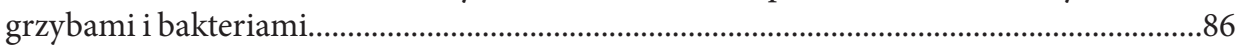

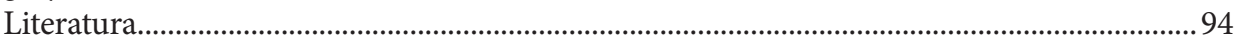

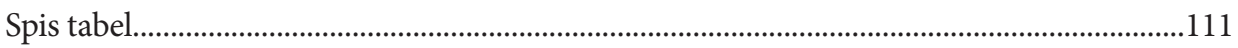




\section{Spis skrótów nazw mikroorganizmów}

A. absinthium - Artemisia absinthium
E. aerogenes - Enterobacter aerogenes

A. alternata - Alternaria alternata

A. baumannii - Actinetobacter baumannii

A. carbonarius - Aspergillus carbonarius

A. clavatus - Aspergillus clavatus

A. flavus - Aspergillus flavus

A. fumigatus - Aspergillus fumigatus

A. nidulans - Aspergillus nidulans

A. niger - Aspergillus niger

A. nomius - Aspergillus nomius

A. ochraceus - Aspergillus ochraceus

A. oryzae - Aspergillus oryzae

A. parasiticus - Aspergillus parasiticus

A. pullulans - Aureobasidium pullulans

A. solani - Alternaria solani

A. terreus - Aspergillus terreus

A. versicolor - Aspergillus versicolor

A. westerdijkiae - Aspergillus westerdijkiae

B. adolescentis - Bifidobacterium adolescentis

B. animalis - Bifidobacterium animalis

B. bifidum - Bifidobacterium bifidum

B. breve - Bifidobacterium breve

B. cereus - Bacillus cereus

B. cinerea - Botrytis cinerea

B. lactis - Bifidobacterium lactis

B. longum - Bifidobacterium longum

B. megaterium - Bacillus megaterium

B. sorokiniana - Bipolaris sorokiniana

B. subtilis - Bacillus subtilis

C. albicans - Candida albicans

C. difficile - Clostridioides difficile

C. dubliniensis - Candida dubliniensis 
C. glabrata - Candida glabrata

C. gloeosporioides - Colletotrichum gloeosporioides

C. guilliermondii - Candida guilliermondii

C. jejuni-Campylobacter jejuni

C. kefyr-Candida kefyr

C. krusei - Candida krusei

C. neoformans - Cryptococcus neoformans

C. parapsilosis - Candida parapsilosis

C. perfringens - Clostridium perfringens

C. sakazakii - Cronobacter sakazakii

C. sphaerospermum - Cladosporium sphaerospermum

C. sporogenes - Clostridium sporogenes

C. tropicalis - Candida tropicalis

C. violaceum - Chromobacterium violaceum

D. hansenii - Debaryomyces hansenii

E. aerogenes - Enterobacter aerogenes

E. cloacae - Enterobacter cloacae

E. coli-Escherichia coli

E. faecalis - Enterococcus faecalis

F. culmorum - Fusarium culmorum

F. graminearum - Fusarium graminearum

F. moniliforme - Fusarium moniliforme

F. oxysporum - Fusarium oxysporum

F. poae - Fusarium poae

F. proliferatum - Fusarium proliferatum

F. sambucinum - Fusarium sambucinum

F. solani-Fusarium solani

F. sulphureum - Fusarium sulphureum

F. verticillioides - Fusarium verticillioides

G. graminis - Gaeumannomyces graminis

G. lucidum - Ganoderma lucidum

H. ducreyi - Haemophilus ducreyi

H. pylori - Helicobacter pylori

H. simplex - Herpes simplex

K. apiculata - Kloeckera apiculata

K. pneumoniae - Klebsiella pneumoniae

L. acidophilus - Lactobacillus acidophilus

L. amylovorus - Lactobacillus amylovorus

L. casei - Lactobacillus casei

L. fermentum - Lactobacillus fermentum

L. gasseri - Lactobacillus gasseri

L. ivanovii - Listeria ivanovii

L. johnsonii - Lactobacillus johnsonii

L. lactis - Lactococcus lactis

L. maculans - Leptosphaeria maculans

L. monocytogenes - Listeria monocytogenes

L. paracasei - Lactobacillus paracasei 
L. plantarum - Lactobacillus plantarum

L. pseudotheobromae - Lasiodiplodia pseudotheobromae

L. reuteri - Lactobacillus reuteri

L. rhamnosus - Lactobacillus rhamnosus

L. salivarius - Lactobacillus salivarius

L. theobromae - Lasiodiplodia theobromae

M. flavus - Micrococcus flavus

M. hominis - Mycoplasma hominis

M. indicus - Mucor indicus

M. luteus - Micrococcus luteus

M. tuberculosis - Mycobacterium tuberculosis

MRSA - methicyllin-resistant (oporny na metycylinę) Staphylococcus aureus

N. gonorrhoeae - Neisseria gonorrhoeae

P. aeruginosa - Pseudomonas aeruginosa

P. cryptogea - Phytophthora cryptogea

P. decumbens - Penicillium decumbens

P. fischeri-Photobacterium fischeri

P. fluorescens - Pseudomonas fluorescens

P. funiculosum - Penicillium funiculosum

P. giseofulvum - Penicillium griseofulvum

P. infestans - Phytophthora infestans

P. irregulare - Pythium irregulare

P. italicum - Penicillium italicum

P. luminescens - Photorhabdus luminescens

P. membranifaciens - Pichia membranifaciens

P. mirabilis - Proteus mirabilis

P. nordicum - Penicillium nordicum

P. notatum - Penicillium notatum

P. ochrochloron - Penicillium ochrochloron

$P$. verrucosum - Penicillium verrucosum

P. vulgaris - Proteus vulgaris

R. solani - Rhizoctonia solani

S. aureus - Staphylococcus aureus

S. boydii - Shigella boydii

S. cerevisiae - Saccharomyces cerevisiae

S. cerevisiae (boulardii) - Saccharomyces cerevisiae boulardii

$S$. Choleraesuis - Salmonella enterica subsp. enterica ser. Choleraesuis

S. dysenteriae - Shigella dysenteriae

S. enterica - Salmonella enterica

S. Enteritidis - Salmonella enterica subsp. enterica ser. Enteritidis

S. flexneri - Shigella flexneri

S. fuliginea - Sphaerotheca fuliginea

$S$. Infantis - Salmonella enterica subsp. enterica ser. Infantis

S. marcescens - Serratia marcescens

S. nodorum - Septoria nodorum

S. Paratyphi - Salmonella enterica subsp. enterica ser. Paratyphi

S. pyogenes - Streptococcus pyogenes 
S. rolfsii - Sclerotium rolfsii

S. sclerotiorum - Sclerotinia sclerotiorum

S. salivarius ssp. thermophilus - Streptococus salivarius ssp. thermophilus

S. Typhi - Salmonella enterica subsp. enterica ser. Typhi

$S$. Typhimurium - Salmonella enterica subsp. enterica ser. Typhimurium

S. vesicarium - Stemphylium vesicarium

T. mentagrophytes - Trichophyton mentagrophytes

T. viride - Trichoderma viride

U. urealyticum - Ureaplasma urealyticum

V. parahaemolyticus - Vibrio parahaemolyticus

$X$. axonopodis pv. citri - Xanthomonas axonopodis pv. citri

$X$. campestris pv. campestris - Xanthomonas campestris pv. campestris

Y. enterocolitica - Yersinia enterocolitica 


\section{Wstęp}

Od zarania dziejów człowiek wykorzystywał rośliny do leczenia chorób infekcyjnych. Niektóre z tych preparatów są nadal stosowane w tradycyjnej medycynie. Odkrycie i zastosowanie antybiotyków oraz innych leków przeciwdrobnoustrojowych umożliwiło skuteczne leczenie infekcji. Jednak wraz z rozpowszechnieniem się tych chemioterapeutyków drobnoustroje wykształciły mechanizmy oporności i zmniejszyła się skuteczność działania tych środków. Coraz większym wyzwaniem dla współczesnej medycyny staje się oporność drobnoustrojów na leki, paradoksalnie spowodowana upowszechnieniem antybiotyków i innych leków o szerokim spektrum antydrobnoustrojowego działania. Wzrastające zagrożenie kliniczne, zwiększone ryzyko zachorowalności i śmiertelności związane z opornością chorobotwórczych drobnoustrojów na większość stosowanych leków skłania do podejmowania nowych działań. Jednym z nich jest poszukiwanie substancji o aktywności przeciwdrobnoustrojowej w materiale roślinnym. Rośliny są bogate w związki bioaktywne o szerokim spektrum działania. Niejednokrotnie wykazano doświadczalnie, że ekstrakty i substancje pozyskiwane $\mathrm{z}$ roślin są równie skuteczne w przeciwdrobnoustrojowym działaniu co tradycyjne leki syntetyczne. Badania antydrobnoustrojowe in vitro ekstraktów z roślin są ważne dla współczesnej medycyny, jednak ich przydatność nie może być przeceniana, jeśli metody nie są standaryzowane w celu uzyskania porównywalnych i powtarzalnych wyników. Wiele ze współcześnie prowadzonych badań koncentruje się na określeniu działania przeciwdrobnoustrojowego ekstraktów roślinnych lub wyizolowanych z nich związków. Przegląd danych zaczerpniętych $\mathrm{z}$ literatury, zaprezentowany $\mathrm{w}$ tej monografii, przybliży czytelnikowi metody i techniki stosowane do pozyskiwania substancji bioaktywnych z roślin i testowania ich antydrobnoustrojowego oddziaływania, a także zapozna go z głównymi kierunkami badań nad wykorzystaniem roślinnych ekstraktów. 


\section{Najczęściej stosowane metody do oceny aktywności przeciwdrobnoustrojowej ekstraktów z roślin}

W ostatnich latach prowadzone są intensywne badania nad właściwościami przeciwdrobnoustrojowymi ekstraktów pochodzenia roślinnego. Wynika to z faktu, iż poszukuje się nowych, skutecznych środków leczniczych, które mogłyby wzbogacić rynek związków terapeutycznych niszczących drobnoustroje chorobotwórcze dla człowieka i zwierząt. Preparaty pochodzenia roślinnego wykazują potencjał bójczy w stosunku do patogenów roślin i stanowią realny substytut pestycydów chemicznych, szczególnie w ramach rolnictwa zintegrowanego i ekologicznego. Dlatego ważnym zagadnieniem są dostępne metody laboratoryjne, stosowane do badań właściwości przeciwdrobnoustrojowych in vitro, które są łatwe do porównania między sobą oraz charakteryzują się powtarzalnością i odtwarzalnością. Najbardziej znane i proste do zastosowania metody opierają się na zjawisku dyfuzji oraz wykonaniu rozcieńczeń zarówno w pożywkach płynnych, jak i stałych. W dalszej kolejności rekomendowane są test time-kill oraz metoda cytometrii przepływowej, dostarczające informacji o naturze efektu inhibicji (bójczym lub statycznym, zależnym od czasu lub stężenia substancji aktywnej). Inna coraz częściej stosowana metoda bazuje na zjawisku bioluminescencji [Balouiri i in. 2016]. Wszystkie metody służą do określenia charakteru badanej substancji przeciwdrobnoustrojowej na poziomie podstawowym lub zaawansowanym, w laboratoriach o różnym stopniu wyposażenia, wykwalifikowania pracowników laboratoryjnych oraz dostępności środków finansowych na badania.

\section{Metody dyfuzyjne}

\section{Metoda krążkowo-dyfuzyjna}

Jest to metoda znana od 1940 r. i oficjalnie stosowana w wielu laboratoriach mikrobiologii klinicznej. Metoda jest wystandaryzowana dla wielu bakterii 
o przeciętnych wymaganiach odżywczych oraz dla niektórych, bardziej wymagających jak Streptokoki, Haemophilus spp., Neisseria spp. [Clinical and Laboratory Standards Institute 2012]. Jest to metoda referencyjna Europejskiego Komitetu Badań Wrażliwości na Antybiotyki (European Comittee on Antimicrobial Susceptibility Testing, EUCAST) oraz polskiego Krajowego Ośrodka Referencyjnego ds. Lekowrażliwości Drobnoustrojów (KORLD). Test wykonuje się na sterylnych płytkach Petriego z pożywką agarową (np. Mueller-Hintona), którą na początku zaszczepia się określoną objętością wystandaryzowanego inokulum szczepu testowanego np. 0,5 stopnia McFarlanda, co odpowiada $1-2 \cdot 10^{8} \mathrm{jtk} \cdot \mathrm{cm}^{-3}$ bakterii E. coli (jtk - jednostek tworzących kolonie), tak aby otrzymać jednolity wzrost na powierzchni podłoża. Po czasie potrzebnym do wchłonięcia hodowli drobnoustrojów do podłoża, na powierzchnię nanosi się krążki bibułowe (o średnicy $6 \mathrm{~mm}$ ) zawierające określoną substancję czynną w pożądanym stężeniu. Następnie płytki inkubuje się w określonych warunkach. Na przykład, dla wielu bakterii stosuje się temperaturę $35 \pm 2{ }^{\circ} \mathrm{C}$ i czas inkubacji ok. $18 \mathrm{~h}$. W tym czasie czynnik przeciwdrobnoustrojowy dyfunduje do podłoża i hamuje podziały komórek oraz wzrost mikroorganizmu wokół naniesionego krążka. Ostatnią czynnością jest pomiar średnicy strefy zahamowania wzrostu mikroorganizmu wrażliwego i ocena stopnia jego wrażliwości, a tym samym skuteczności działania substancji aktywnej. Im strefa inhibicji wzrostu jest większa, tym większa jest też skuteczność preparatu. Metoda ta jest rutynowo wykorzystywana do sporządzania antybiogramów podczas doboru skutecznego antybiotyku do terapii pacjentów, ale może być także stosowana we wstępnych badaniach aktywności przeciwdrobnoustrojowej różnych związków chemicznych i mieszanin, w tym ekstraktów i olejków roślinnych. Metoda ta jednak nie daje informacji o tym, czy badana substancja działa bójczo, czy tylko hamuje wzrost. Ponadto metoda nie określa minimalnego stężenia hamującego wzrost, gdyż nie można dokładnie oznaczyć stężenia substancji dyfundującej do podłoża w określonej odległości od krążka. Ma jednak wiele zalet, takich jak prostota, niski koszt, możliwość testowania dużej ilości mikroorganizmów i związków aktywnych oraz łatwość interpretacji otrzymanych wyników [Balouiri i in. 2016, Saibabu i in. 2018]. Hsieh i in. [2001] zastosowali metodę krążkowo-dyfuzyjną do oznaczenia działania kombinacji ekstraktów roślinnych z cynamonu, owoców gatunku derenia Cornus officinalis oraz czosnku chińskiego Allium tuberosum na bakterie: E. coli, B. subtilis, Flavobacterium sp., L. monocytogenes, P. aeruginosa, S. Typhimurium, S. aureus, V. parahaemolyticus; grzyby: A. flavus, A. niger, P. italicum i A. pullulans oraz drożdże: K. apiculata, P. membranefaciens i D. hansenii. More i Kharat [2016] tą metodą skuteczne określili działanie ekstraktów z korzeni i łodyg kolczastego maku - Argemone mexicana - na grzyby chorobotwórcze takie jak: A. flavus, A. niger, $P$. notatum i $M$. indicus.

\section{Metoda studzienkowo-dyfuzyjna}

Metoda studzienkowo-dyfuzyjna jest podobna do metody krążkowej. Przygotowaną płytkę Petriego z pożywką agarową zaszczepia się powierzchniowo inokulum 
o określonej gęstości komórek. Po wchłonięciu hodowli drobnoustrojów należy sterylnie wyciąć otworki w agarze o średnicy $6-8 \mathrm{~mm}$ za pomocą korkoboru lub końcówki do pipety i wprowadzić do nich substancję badaną o określonym stężeniu w objętości 20-100 $\mu \mathrm{l}$, w zależności od wielkości studzienki. Zazwyczaj na dno studzienki nanosi się $10 \mu \mathrm{l}$ agaru miękkiego, aby badana ciecz nie dostawała się pod warstwę pożywki. Płytki z naniesioną substancją bójczą poddaje się inkubacji w odpowiedniej temperaturze. Po inkubacji należy dokonać pomiaru średnicy strefy zahamowania wzrostu testowego mikroorganizmu i ocenić stopień jego wrażliwości, a tym samym skuteczność bójczą ekstraktu lub innego czynnika przeciwdrobnoustrojowego [Balouiri i in. 2016]. Metoda jest często stosowana podczas analizy ekstraktów roślinnych lub oczyszczonych składników wyciągów roślin. Puupponen-Pimiä i in. [2001] tą metodą badali właściwości przeciwdrobnoustrojowe ekstraktów oraz związków fenolowych otrzymanych z owoców jagodowych wobec bakterii z rodzaju Lactobacillus spp., E. coli, S. Typhimurium, E. faecalis i B. lactis.

\section{Metody rozcieńczeń}

Metody rozcieńczeń służą do ilościowego pomiaru in vitro aktywności przeciwdrobnoustrojowej substancji badanych wobec bakterii i grzybów. Stosowane są do określenia wartości MIC - minimalnego stężenia hamującego wzrost. Wartość MIC definiowana jest jako najmniejsze stężenie czynnika przeciwdrobnoustrojowego, które hamuje wizualny wzrost testowanego mikroorganizmu i wyrażana jest w jednostkach stężenia $\mu \mathrm{g} \cdot \mathrm{cm}^{-3} \mathrm{lub} \mathrm{mg} \cdot \mathrm{cm}^{-3}$ [Balouiri i in. 2016, Saibabu $i$ in. 2018]. Należy stosować odpowiednie procedury dla bakterii wymagających i niewymagających, drożdży oraz grzybów pleśniowych. Większość procedur ustalana jest przez Instytut Norm Klinicznych i Laboratoryjnych (The Clinical and Laboratory Standards Institute, CLSI) w USA i Europejski Komitet Badań Wrażliwości na Antybiotyki (EUCAST). W praktyce stosuje się metodę agarową lub bulionową (makro- lub mikrorozcieńczeń).

Metoda bulionowa (zawiesinowa) polega na przygotowaniu szeregu rozcieńczeń badanego preparatu przeciwdrobnoustrojowego (np. rozcieńczeń dwukrotnych) w probówkach (makrorozcieńczenia) lub dołkach mikropłytek (mikrorozcieńczenia) w pożywce hodowlanej. Następnie do probówek lub dołków wprowadza się zawiesinę szczepu testowego w tym samym podłożu. Inokulum najczęściej ma gęstość komórek odpowiadającą 0,5 stopnia McFarlanda. Zaszczepione probówki lub mikropłytki po wymieszaniu poddaje się inkubacji w optymalnej temperaturze przez określony czas, po czym sprawdza się obecność wzrostu komórek wizualnie lub poprzez pomiar zmętnienia lub gęstości optycznej, szczególnie w metodzie mikrorozcieńczeń [Balouiri i in. 2016]. Wiadomo, że wartość MIC zależy od wielkości i metody przygotowania inokulum, typu 
podłoża wzrostowego oraz czasu inkubacji [Gomez-Lopez i in. 2005]. Metoda makrorozcieńczeń wykonywana jest manualnie, zawiera duże ryzyko popełnienia błędu podczas przygotowywania rozcieńczeń i wymaga stosunkowo dużych ilości reagentów [Jorgensen i Ferraro 2009]. Natomiast metoda mikrorozcieńczeń jako zminiaturyzowana wymaga mniej odczynników, generuje niższe koszty analizy i zapewnia większą powtarzalność dzięki stosowaniu zautomatyzowanego odczytu mikropłytek. W przypadku analizy dotyczącej grzybów pleśniowych standaryzacja zawiesiny zarodników lub konidiów polega na pomiarze spektrofotometrycznym lub liczeniu $\mathrm{w}$ hemocytometrze, a ich liczba powinna mieścić się w przedziale $10^{4}-10^{5} \cdot \mathrm{cm}^{-3}$. Określenie minimalnego stężenia bakteriobójczego (MBC - minimal bactericidal concentration) lub grzybobójczego (MFC - minimal fungicidal concentration) badanej substancji aktywnej bywa też określane minimalnym stężeniem letalnym (MLC - minimal lethal concentration) i jest definiowane jako najmniejsze stężenie czynnika przeciwdrobnoustrojowego potrzebne do zabicia $99,9 \%$ początkowego inokulum po inkubacji przez $24 \mathrm{~h}$ w warunkach wystandaryzowanych, opisanych w odpowiednim dokumencie. Do tego oznaczenia należy pobrać próbkę hodowli z probówki lub dołka mikropłytki wykazującą brak wzrostu drobnoustroju testowanego i posiać ją na nieselektywną pożywkę agarową, aby określić liczbę komórek, które przeżyły po $24 \mathrm{~h}$ inkubacji. W ten sposób można określić stopień przeżywalności bakterii. Natomiast analiza MFC oznacza najmniejsze stężenie substancji powodujące zabicie $98-99,9 \%$ początkowego inokulum badanego grzyba [Balouiri i in. 2016]. Metoda mikrorozcieńczeń była wykorzystywana do badań nad wpływem składników olejku sezamowego lub olejku eterycznego z lawendy na C. albicans [Ansari i in. 2016a, 2016b]. Sharma $\mathrm{i}$ in. [2016] badali tą metodą aktywność przeciwdrobnoustrojową ekstraktów z Grewia asiatica L. wobec C. albicans i A. fumigatus.

Metoda agarowa polega na dodaniu czynnika przeciwdrobnoustrojowego w odpowiednich stężeniach (najczęściej wielokrotności dwukrotnych rozcieńczeń) do płynnej pożywki agarowej o temp. $50^{\circ} \mathrm{C}$, wylaniu pożywek z różnymi stężeniami badanej substancji na płytki Petriego i zaszczepieniu powierzchniowym inokulum drobnoustrojów o odpowiedniej gęstości komórek $\left(1-2 \cdot 10^{8} \mathrm{jtk} \cdot \mathrm{cm}^{-3}\right)$. W metodzie tej wartość MIC jest definiowana jako najmniejsze stężenie czynnika aktywnego, które hamuje wzrost w określonych warunkach inkubacji, np. dla bakterii w temp. $35 \pm 2^{\circ} \mathrm{C}$ w ciągu $16-20 \mathrm{~h}$. Technika ta jest odpowiednia zarówno do oznaczania działania antybakteryjnego, jak i antygrzybowego. Metoda agarowa może być wykorzystana zamiast bulionowej w przypadku jednoczesnego oznaczania wrażliwości wielu drobnoustrojów na daną substancję lub w trudności w użyciu podłoża płynnego do oceny wzrostu drobnoustroju [Balouiri i in. 2016]. Metoda ta była stosowana do oceny przeciwdrobnoustrojowych właściwości indyjskich roślin leczniczych takich jak: Azadirachta indica, Acacia nilotica, Curcuma longa i Withania simnifera wobec A. flavus [Alavijeh i in. 2012] oraz roślin Cassia occidentalis, Lawsonia inermis, Cassia tora, Caesalpinia bonducella i Xanthium strumarium wobec różnych grzybów dermatofitycznych [Sagar i Vidyasagar 2013]. 


\section{Test time-kill}

Test time-kill (czasu potrzebnego do zabicia drobnoustrojów) należy do testów zawiesinowych i jest przeprowadzany w celu oceny redukcji liczby mikroorganizmów przez badaną substancję o działaniu przeciwdrobnoustrojowym w czasie oraz służy do określenia jej aktywności bakteriobójczej lub bakteriostatycznej. Test pokazuje efekt przeciwdrobnoustrojowy w zależności od czasu działania i od stężenia substancji aktywnej [Saibabu i in. 2018]. O aktywności bójczej świadczy spadek liczby drobnoustrojów o co najmniej 3 logarytmy dziesiętne, co odpowiada śmiertelności na poziomie $99,9 \%$. Analiza czasu zabijania może monitorować wpływ różnych stężeń środka przeciwdrobnoustrojowego w czasie w stosunku do etapów wzrostu bakterii (faza spoczynkowa, faza wykładnicza, faza stacjonarna). Analizie można poddawać różne drobnoustroje w zależności od badanego środka bójczego i jego dalszego planowanego przeznaczenia. Najczęściej przeprowadza się ją z użyciem popularnych mikroorganizmów potencjalnie chorobotwórczych: $S$. aureus, $S$. Choleraesuis, P. aeruginosa, E. coli, A. niger i T. mentagrophytes.

Badaną substancję lub jej roztwór dodaje się do przygotowanej płynnej hodowli drobnoustrojów o liczbie około $10^{6} \mathrm{jtk} \cdot \mathrm{cm}^{-3} \mathrm{i}$ inkubuje przez określony czas $\mathrm{w}$ optymalnej temperaturze. $\mathrm{W}$ wybranych punktach czasowych, w tym w czasie zerowym, pobiera się próbki, które poddane są najpierw neutralizacji środka bójczego. Następnie należy wykonać szereg dziesięciokrotnych rozcieńczeń badanej próby i posiać je na płytki Petriego z odpowiednią pożywką agarową. Po inkubacji $\mathrm{w}$ warunkach optymalnych dla mikroorganizmu liczy się wyrosłe kolonie i określa liczbę drobnoustrojów przypadającą na $1 \mathrm{~cm}^{3}$ próby. Znając liczbę początkową populacji badanych mikroorganizmów i ich liczbę, po określonym czasie kontaktu z substancją bójczą należy wyliczyć stopień redukcji ilości drobnoustrojów w procentach lub logarytmach. Ponadto metoda może być użyta do badania synergizmu lub antagonizmu pomiędzy substancjami stosowanymi w kombinacjach [Balouiri i in. 2016, Saibabu i in. 2018]. Jest to najbardziej odpowiednia metoda do oznaczania aktywności bójczej produktów naturalnych. Była używana do badania synergistycznych właściwości ekstraktów roślin: Terminalia catappa, Terminalia mantyla i Monodora teniufolia przeciwko C. albicans, C. glabrata, C. parapsilosis i $C$. neoformans. Wykazała pozytywny efekt grzybobójczy [Ngouana i in. 2015]. W innych badaniach zastosowano test time-kill do sprawdzenia efektu synergistycznego glabridyny izolowanej z rośliny Glycyrrhiza gabra w kombinacji z flukonazolem na drożdżaki chorobotwórcze C. albicans, C. tropicalis i C. neoformans, w którym uzyskano prawie całkowity efekt bójczy w jednej z użytych kombinacji [Liu i in. 2014].

\section{Oznaczanie kiełkowania zarodników grzybów}

Jest to technika mikroskopowa przeznaczona do oznaczania aktywności przeciwgrzybowej ekstraktów roślinnych. Polega na naniesieniu na powierzchnię 
suchego szkiełka mikroskopowego ekstraktu roślinnego o pożądanym stężeniu i objętości w postaci cienkiej warstwy (filmu) lub kropli - w przypadku użycia szkiełka z wgłębieniem. Następnie nanosi się na szkiełko określoną objętość zawiesiny zarodników grzyba. Przygotowany preparat inkubuje się w płytkach Petriego, umieszczonych na szklanych bagietkach w warunkach wilgotnych, w określonej temperaturze przez $24 \mathrm{~h}$. Po inkubacji preparaty są utrwalane błękitem laktofenolowym i poddane obserwacji mikroskopowej pod kątem kiełkowania zarodników. Należy policzyć ilość zarodników kiełkujących w stosunku do całkowitej liczby zarodników w preparacie i obliczyć stopień procentowy kiełkowania. Metoda jest stosowana do badania właściwości przeciwgrzybowych produktów naturalnych wobec patogenów roślin, zwierząt oraz pochodzących z żywności, np. w badaniach nad grzybami z rodzaju Aspergillus [Gemeda i in. 2014]. Natomiast Vediyappan i in. [2013] użyli tej metody do określenia działania hamującego kwasów gymnemowych, wyizolowanych z liści rośliny leczniczej Gymnea sylvestre na konwersję komórek drożdżowych C. albicans do postaci mycelium oraz na kiełkowanie i wzrost strzępek A. fumigatus [Vediyappan i in. 2013].

\section{Hodowla na podłożu z dodatkiem substancji przeciwdrobnoustrojowej}

Metoda jest głównie stosowana do badania aktywności antygrzybowej. Czynnik bójczy jest najpierw dodawany do upłynnionej pożywki agarowej w pożądanym stężeniu końcowym. Następnie pożywka jest rozlewana na płytki Petriego i po zastygnięciu szczepiona centralnie fragmentem grzybni o średnicy $2-5 \mathrm{~mm}$, po czym podlega inkubacji w odpowiednich warunkach. Po inkubacji należy zmierzyć średnicę wzrostu grzybni szczepu testowanego oraz średnicę wzrostu kontrolnego na pożywce bez dodatku substancji przeciwdrobnoustrojowej. Kolejnym krokiem jest obliczenie aktywności przeciwgrzybowej według następującego wzoru:

Aktywność przeciwgrzybowa $(\%)=[(\mathrm{Dc}-\mathrm{Ds}) / \mathrm{Dc}] \cdot 100$

gdzie Dc to średnica wzrostu grzybni kontrolnej, Ds - średnica wzrostu grzybni testowanej. W przypadku, gdy standaryzacja metody kończy się niepowodzeniem, należy wykonać kontrolę pozytywną ze znanym związkiem przeciwdrobnoustrojowym i porównać wyniki, aby stwierdzić poprawność eksperymentu [Balouiri i in. 2016]. Kumar i Tyagi [2013] powyższą metodą badali działanie rośliny Bergenia stracheyi na grzyby: A. niger, A. alternata, C. gleosporioides, F. oxysporum, $R$. solani i G. lucidum. Technika ta była również używana do określenia wpływu olejku i ekstraktu z czosnku na C. albicans [Li i in. 2016]. 


\section{Bioautografia połączona z chromatografią cienkowarstwową}

Procedura bioautografii zbliżona jest do metody agarowej dyfuzyjnej. Różnica polega na tym, że związek aktywny dyfunduje z warstwy płytki chromatograficznej do agaru [Choma i Grzelak 2011]. Metoda została opracowana w latach 40. XX w. do badań nad działaniem penicylin i wówczas łączyła chromatografię bibułową (PC - paper chromatography) z posiewem na pożywkę agarową drobnoustroju testowanego. W latach 60. XX w. Fischer i Lautner [1961] zmodyfikowali ją, zastępując chromatografię bibułową chromatografią cienkowarstwową (thin-layer chromatography - TLC). Metoda łączy detekcję chemiczną z biologiczną i obecnie jest stosowana do skriningu ekstraktów roślinnych pod kątem ich aktywności przeciwdrobnoustrojowej. Wyróżnia się trzy techniki bioautograficzne stosowane do tego celu: metodę dyfuzyjną-kontaktową, bezpośrednią bioautografię i test nakładki agarowej.

Metoda dyfuzyjna-kontaktowa obejmuje transfer czynnika przeciwdrobnoustrojowego z chromatogramu PC lub TLC na zasadzie dyfuzji do płytki Petriego z odpowiednim podłożem agarowym uprzednio zaszczepionym testowanym mikroorganizmem. Po określonym czasie niezbędnym do dyfuzji (minuty lub godziny), chromatogram jest usuwany, a płytka poddana inkubacji w warunkach odpowiednich do wzrostu mikroorganizmu. Jeżeli badana substancja aktywna działała hamująco na drobnoustroje, wówczas w miejscu kontaktu chromatogramu z agarem nie pojawi się wzrost mikroorganizmu [Choma i Grzelak 2011, Marston 2013].

Bezpośrednia bioautografia polega na zanurzeniu rozwiniętej płytki TLC w bulionowej zawiesinie mikroorganizmów testowanych lub spryskaniu płytki taką zawiesiną. Następnie bioautogram poddaje się inkubacji w $25^{\circ} \mathrm{C}$ przez $48 \mathrm{~h}$ w warunkach wilgotnych, podczas której drobnoustroje korzystają ze składników odżywczych i rozwijają się bezpośrednio na płytce TLC [Dewanjee i in. 2015]. Kolejnym krokiem jest wizualizacja wzrostu drobnoustrojów za pomocą soli tetrazoliowych, które ulegają konwersji do formazanu dzięki dehydrogenazom obecnym w żywych komórkach [Choma i Grzelak 2011]. Solami tymi spryskuje się bioautogram, a następnie prowadzi się dalszą inkubację $\mathrm{w} 25^{\circ} \mathrm{C}$ przez $24 \mathrm{~h}$ lub w $37^{\circ} \mathrm{C}$ przez $3-4 \mathrm{~h}$. Wzrost mikroorganizmów widoczny jest w postaci purpurowego tła, a w miejscu działania substancji przeciwdrobnoustrojowej powstają biało-kremowe plamki. Podłoże, które można zastosować na płytkę TLC to bulion Mueller-Hintona [Shahat i in. 2008]. Metoda ta może być stosowana zarówno do bakterii, jak i grzybów. Technika była stosowana do badań wrażliwości $B$. subtilis, E. coli i S. aureus na olejki roślinne [Horvath i in. 2010]. Wykorzystano ją do badań nad antygrzybowym działaniem olejków roślinnych na Aspergillus sp., Penicillium sp. i Cladosporium sp. [Suleiman i in. 2010].

Test nakładki agarowej znany jest również pod nazwą bioautografia immersyjna. Jest to połączenie dwóch poprzednich metod. Płytka TLC jest pokrywana upłynnionym, zaszczepionym drobnoustrojami podłożem agarowym. Najpierw jest umieszczona w niskiej temperaturze na kilka godzin, aby umożliwić dyfuzję 
związków aktywnych z płytki TLC do pożywki agarowej. Następnie płytki są inkubowane w warunkach optymalnych dla mikroorganizmu testowego, w kolejnym etapie następuje barwienie barwnikiem tetrazoliowym w celu wizualizacji wzrostu [Balouiri in. 2016]. Metoda ta może być stosowana do wszystkich mikroorganizmów, daje dobrze zdefiniowane strefy zahamowania wzrostu i słabo ulega zanieczyszczeniu [Choma i Grzelak 2011, Marston 2013].

Wszystkie rodzaje bioautografii połączonej z TLC są technikami prostymi, efektywnymi i tanimi służącymi do jednoczesnej separacji związków i wykazania ich aktywności przeciwdrobnoustrojowej. Mogą być stosowane zarówno w laboratoriach bardzo dobrze wyposażonych, jak i skromniejszych do szybkiego skriningu bioaktywności i analizy dużej ilości prób różnego pochodzenia [Dewanjee i in. 2015].

\section{Metoda bioluminescencji}

Zjawisko luminescencji, czyli emisji fal świetlnych przez ciała zwane luminoforami, zachodzi pod wpływem różnych rodzajów energii z wyjątkiem energii cieplnej, natomiast bioluminescencja to emisja promieniowania świetlnego w zakresie światła widzialnego przez organizmy żywe [Szosland-Fałtyn i Królasik 2014, Pajor i in. 2017]. W metodzie tej związek chemiczny - lucyferyna w obecności adenozynotrifosforanu (ATP) komórkowego ulega konwersji do oksylucyferyny z udziałem kompleksu enzymatycznego lucyferazy, syntetyzowanego w komórkach pod kontrolą operonu luxCDABE i w obecności tlenu. Sygnał luminescencji jest generowany po uwolnieniu komórkowego ATP, który jest wykrywalny po 10 min inkubacji. Analiza bioluminescencji jest stosowana do pomiaru stężenia ATP produkowanego przez żywe komórki. Jej natężenie jest wprost proporcjonalne do stężenia ATP. Zatem ilość ATP może służyć do oceny ilościowej populacji mikroorganizmów w próbce [Saibabu i in. 2018]. Ilość emitowanego światła mierzona jest luminometrem i wyrażana we względnych jednostkach światła (RLU - relative light unit), konwertowanych do RLU/mol ATP. Liczba tych jednostek jest wprost proporcjonalna do żywotności komórek. Komercyjnie dostępne luminometry wykrywają mniej niż 0,1 pg ATP $\left(10^{-13} \mathrm{~g}\right)$, co odpowiada 100 komórkom bakterii. Zawartość ATP w komórkach organizmów testowanych zależy od rodzaju drobnoustrojów, wielkości komórki, fazy wzrostu, stanu fizjologicznego i uszkodzeń subletalnych. Komórki drożdży, zarodników pleśni i alg zawierają średnio 100 razy więcej ATP niż komórki bakterii, a w endosporach bakterii występuje on w minimalnych stężeniach. Dokładne stężenia ATP w różnych komórkach zostały opisane w literaturze, natomiast średnia zawartość ATP w komórce bakterii jest szacowana na $10^{-18}$ mola ATP [Shama i Malik 2013, Szosland-Fałtyn i Królasik 2014]. W metodzie bioluminescencji można wykorzystać drobnoustroje naturalnie wyposażone w operon $\operatorname{lux} C D A B E G$, którego ekspresja umożliwia powstanie 
wszystkich produktów niezbędnych do emisji promieniowania świetlnego, bez potrzeby pobierania substratów z zewnątrz (np. z rodzaju Photobacterium) lub drobnoustroje modyfikowane genetycznie, zawierające wprowadzone geny niezbędne do zajścia procesu bioluminescencji. Cechą wspólną jest interakcja między lucyferazą a lucyferyną, która generuje sygnał wykrywany przez luminometr [Pajor i in. 2017].

Odmianą tej metody jest podawanie z zewnątrz enzymu lucyferazy i substratu lucyferyny do hodowli dowolnych mikroorganizmów i pomiar stężenia ATP komórkowego. Zaletą metody jest jej szybkość, nieinwazyjność, czułość, możliwość stosowania in vivo i in situ oraz to, że niepotrzebni są wysoko wykwalifikowani pracownicy laboratoryjni. Jednak jej wadą jest niedokładność wyników ilościowych. Metoda oznaczania ATP z wykorzystaniem gotowych zestawów ma zastosowanie przede wszystkim w określaniu czystości mikrobiologicznej powierzchni produkcyjnych w przemyśle spożywczym i farmaceutycznym oraz w ocenie skuteczności procesów mycia i dezynfekcji [Gutarowska i in. 2012, Szosland-Fałtyn i Królasik 2014].

Obecnie technika bioluminescencji może być wykorzystywana również w badaniach nad właściwościami przeciwdrobnoustrojowymi różnych substancji, w tym ekstraktów roślinnych i związków pochodzenia roślinnego [Balouiri i in. 2016]. Nybond i in. [2015] wykorzystali do badania właściwości przeciwdrobnoustrojowych 136 naturalnych ekstraktów roślinnych rekombinowane bakterie E. coli $\mathrm{K} 12 \mathrm{z}$ plazmidem pCGLS11 zawierającym geny stałej ekspresji lucyferazy. Do hodowli bakterii w bulionie LB z ampicyliną w mikropłytkach dodawano odpowiednio rozcieńczone ekstrakty, a pomiar prowadzono przy użyciu specjalnego czytnika luminescencji, następnie wyliczano procent zahamowania bioluminescencji z uwzględnieniem odpowiednich próbek kontrolnych. Wyniki wykazały użyteczność stosowania bakterii rekombinowanych do skriningu dużej liczby ekstraktów [Nybond i in. 2015]. Podobną analizę wpływu chińskich roślin zielarskich prowadzili Chong i in. [2018], m.in. wykorzystując rekombinanta $E$. coli $\mathrm{pSB} 401$ zawierającego geny lux z $P$. fischeri i $P$. luminescens oraz $E$. coli pSB1075 niosącego geny lux z P. luminescens i gen lasR z P. aeruginosa. Badacze stwierdzili znaczną inhibicję bioluminescencji (spadek liczby RLU w czasie) podczas stosowania ekstraktów z Radix pini, Angelica dauhurica oraz Rhizoma cibotii już po $2 \mathrm{~h}$ inkubacji z bakteriami sensorowymi [Chong i in. 2018].

\section{Cytometria przepływowa}

Cytometria jest metodą pomiaru właściwości fizycznych i/lub chemicznych pojedynczych komórek lub składników komórkowych. Pomiarów dokonuje się w cytometrach przepływowych w trakcie przepływu komórek lub cząstek w stru- 
mieniu cieczy. Ta dziedzina analityki miała swoje początki w latach 40 . XX w., natomiast obecnie rozwija się bardzo szybko wraz z wieloma obszarami techniki i fizyki oraz rozwojem programów komputerowych wykorzystywanych do analizy danych [Baran 2008]. Metoda jest wykorzystywana w diagnostyce medycznej [Skotny i Pucińska 2013], a także w różnych badaniach podstawowych, w tym nad związkami przeciwdrobnoustrojowymi.

Cytometria pozwala w sposób zautomatyzowany analizować stan pojedynczych komórek w bardzo krótkim czasie. Do tego celu stosuje się barwniki fluorescencyjne, dzięki którym można zbadać różne parametry komórkowe drobnoustrojów, $\mathrm{m}$.in. związane z powierzchnią, rozmiarem, budową wewnątrzkomórkową, oddziaływaniami między cząsteczkami oraz stanem błon biologicznych, potencjałem błonowym i aktywnością metaboliczną [Olszewska i in. 2016]. Metoda służy również do rozróżnienia komórek martwych, żywych i uszkodzonych. Jest używana do oceny wielkości komórek i ich granulacji, co jest wskaźnikiem śmierci po działaniu produktów naturalnych [Cho i in. 2013]. Szybka detekcja uszkodzonych komórek zależy od użytych barwników, np. dobre efekty można uzyskać, stosując fluorescencyjny barwnik - jodek propidyny, który interkaluje do DNA komórek $\mathrm{z}$ uszkodzoną błoną komórkową. Inne barwniki stosowane w metodzie to Syto-9 i dioctan fluoresceiny [Chang i in. 2015]. Metoda może być również stosowana do określenia sposobu działania badanych związków aktywnych: uszkodzeń DNA, powstawania reaktywnych form tlenu, apoptozy, właściwości powierzchniowych komórek czy dysfunkcji mitochondrialnych [Saibabu i in. 2018].

W cytometrii przepływowej komórki mikroorganizmów pozostają w zawiesinie, do której dodaje się odpowiedni barwnik fluorescencyjny, czasami też stosuje się utrwalanie próbek. Następnie zawiesinę wprowadza się do aparatu, w którym w komorze pomiarowej strumień pojedynczych komórek przepływa ze stałą prędkością $10^{3} \cdot \mathrm{s}^{-1}$. Przepływające komórki przecinają promień lasera, który emituje światło, a emitowana wiązka światła ulega rozproszeniu. Pomiaru rozproszenia dokonują dwa detektory: przedni i boczny. Pierwszy zbiera wiązkę nierozproszoną lub mało rozproszoną i niesie informacje o rozmiarach komórek, a drugi zbiera sygnały pochodzące $\mathrm{z}$ rozproszenia prostopadłego do padającej wiązki laserowej, co pozwala na wewnątrzkomórkową analizę obiektów. Następuje też pomiar natężenia fluorescencji emitowanej przez próbkę. Następnie światło przechodzi przez układy optyczne, które rozdzielają widma fluorescencji i są one przekształcane na sygnał cyfrowy. Wyniki uzyskuje się w postaci jedno- lub dwuwymiarowych histogramów przedstawiających częstość występowania danej cechy w badanej populacji albo wykresów kropkowych, gdzie każda kropka reprezentuje pojedynczą komórkę. W zależności od mikroorganizmu próg detekcji wynosi około 100 komórek na centymetr sześcienny, natomiast automatyzacja analizy umożliwia wykonanie kilkudziesięciu analiz w ciągu godziny [Skotny i Pucińska 2013, Olszewska i in. 2016].

Metoda może być z powodzeniem stosowana do badań nad działaniem przeciwdrobnoustrojowym wielu substancji, w tym roślinnych olejków eterycznych. 
Na przykład była stosowana podczas określania wpływu olejków eterycznych $\mathrm{z}$ cynamonu, oregano i tymianku na $L$. monocytogenes $\mathrm{z}$ użyciem łączonego barwienia jodkiem propidyny z dioctanem karboksyfluoresceiny do wykrycia aktywności esterazy i integralności błon komórkowych [Paparella i in. 2008]. Prowadzono również badania nad antygrzybowym działaniem olejku z kopru Anethum graveolens L. przeciwko A. flavus, stosując barwienie jodkiem propidyny do wykazania uszkodzeń błony cytoplazmatycznej [Tian i in. 2012]. Z kolei badania nad wpływem kurkuminy wykazały funkcję uszkodzenia błony (wyciek jonów potasowych) w komórkach drożdży C. albicans, co badacze wykazali, stosując bis(1,3-dibutylobarbiturowy kwas) trimetino oksonol w cytometrii przepływowej [Lee i Lee 2014]. Inne badania cytometryczne wykazały, że berberyna - alkaloid pochodzenia roślinnego - powodowała zmiany w integralności plazmy i błonach mitochondrialnych oraz uszkodzenia DNA prowadzące do śmierci komórek drożdżaków odpornych na flukonazol [A.R. da Silva i in. 2016].

Zaletą metody jest jej szybkość w porównaniu z metodą mikrorozcieńczeń (2-6h w porównaniu z 24-72 h) oraz powtarzalność [Ramani i Chaturvedi 2000]. Cytometria przepływowa pozwala na uzyskanie ogromnej ilości informacji z pojedynczego eksperymentu, w tym danych ilościowych [Skotny i Pucińska 2013]. Jednak szerokie wykorzystywanie tej metody do testowania związków przeciwdrobnoustrojowych jest mało prawdopodobne z powodu niedostępności wymaganego sprzętu w wielu laboratoriach [Balouiri i in. 2016]. Ponadto obsługa aparatu wymaga wysoko wykwalifikowanych specjalistów, także do analizy danych niezbędna jest wiedza i doświadczenie [Skotny i Pucińska 2013]. 


\section{Przygotowanie materiału roślinnego do badań jego właściwości przeciwdrobnoustrojowych}

Liczne rośliny lecznicze i przyprawowe zawierają związki biologicznie aktywne o właściwościach przeciwdrobnoustrojowych. Zdolność preparatów roślinnych do zahamowania wzrostu mikroorganizmów lub ich zabicia zależy od wielu czynników, głównie od składu chemicznego, stężenia i rodzaju ekstrakcji, a także od wrażliwości mikroorganizmów. Prowadzone badania dotyczą zarówno przeciwdrobnoustrojowej aktywności wyciągów lub ich frakcji, lub wyizolowanych substancji biologicznie czynnych. Specyfiką badań nad przeciwdrobnoustrojowymi właściwościami eskstraktów jest takie ich przygotowanie, aby zawierały substancje aktywne w stężeniu efektywnym i aby rozpuszczalnik nie wpływał na aktywność biologiczną preparatu.

Naukowcy badają produkty roślinne o właściwościach przeciwdrobnoustrojowych w bardzo zróżnicowany sposób. Badania działania antydrobnoustrojowego ekstraktów roślin są ważne dla współczesnej medycyny, ale ich przydatność jest ograniczona, jeśli metody nie są standaryzowane. Korzystne byłoby ujednolicenie metod ekstrakcji i badań skuteczności antybakteryjnej, tak aby poszukiwanie nowych biologicznie aktywnych produktów roślinnych było bardziej systematyczne i powtarzalne, a interpretacja wyników łatwiejsza.

Biorąc pod uwagę duże zróżnicowanie związków bioaktywnych i ogromną liczbę gatunków roślin, konieczne jest opracowanie usystematyzowanego i zintegrowanego podejścia do ekstrakcji tych związków. W jednym z pierwszych standardów postępowania z roślinami leczniczymi opracowano sekwencję czynności podczas badań właściwości leczniczych roślin [Farnsworth i in. 1985]. 
Tabela 1. Schemat kolejności badań nad roślinami leczniczymi [opracowano na podstawie: Farnsworth i in. 1985]

\begin{tabular}{|c|c|}
\hline Wybór roślin do badań & $\begin{array}{l}\text { Badania przesiewowe roślin leczniczych i roślin tradycyjnie } \\
\text { używanych. } \\
\text { Przegląd publikacji naukowych na temat wybranej rośliny. } \\
\text { Uwierzytelnianie danych pod kątem ich ważności } \\
\text { i kompletności. } \\
\text { Decyzja dotycząca przeprowadzenia badań. }\end{array}$ \\
\hline Ocena toksyczności & $\begin{array}{l}\text { Zebranie danych dotyczących toksyczności wybranej } \\
\text { rośliny. } \\
\text { Jeśli roślina nie wykazuje toksyczności, kontynuować } \\
\text { badania. } \\
\text { Jeżeli dane dotyczące toksyczności nie istnieją, należy } \\
\text { wybrać odpowiednie oznaczenia do celów analizy } \\
\text { toksyczności. } \\
\text { Opracowanie i przygotowanie protokołu w zakresie } \\
\text { bezpieczeństwa i toksyczności. }\end{array}$ \\
\hline $\begin{array}{l}\text { Przygotowanie materiału } \\
\text { roślinnego }\end{array}$ & $\begin{array}{l}\text { Pobieranie próbek. } \\
\text { Ekstrakcja z użyciem różnych technik i oceną selektywności } \\
\text { wyodrębniania związków i wydajności procesu. } \\
\text { Analiza składu chemicznego pod kątem zawartości } \\
\text { substancji bioaktywnych. }\end{array}$ \\
\hline Badania biologiczne & $\begin{array}{l}\text { Wybór odpowiedniego badania biologicznego. } \\
\text { Opracowanie protokołu badań biologicznych. } \\
\text { Analiza aktywności biologicznej in vitro. } \\
\text { Wykrywanie typu i poziomu aktywności biologicznej. }\end{array}$ \\
\hline Izolacja związków bioaktywnych & $\begin{array}{l}\text { Izolacja i charakterystyka związków odpowiedzialnych za } \\
\text { obserwowaną aktywność biologiczną. } \\
\text { Ocena związków bioaktywnych w celu zbadania } \\
\text { wzajemnych interakcji (synergia) podczas wywoływanego } \\
\text { efektu biologicznego. }\end{array}$ \\
\hline Analizy in vivo & $\begin{array}{l}\text { Wykorzystanie modelu zwierzęcego do analizy aktywności } \\
\text { biologicznej związków czynnych. } \\
\text { Analiza bezpieczeństwa i toksyczności w badaniach in vivo. } \\
\text { Przeprowadzenie badań z udziałem ludzi. }\end{array}$ \\
\hline Komercjalizacja produktu & $\begin{array}{l}\text { Opracowanie sposobu dawkowania preparatu. } \\
\text { Analiza kosztów produkcji. } \\
\text { Wdrożenie do produkcji przemysłowej. }\end{array}$ \\
\hline
\end{tabular}

\section{Surowiec do badań}

Skład chemiczny rośliny zależy od wielu czynników, głównie od glebowo-klimatycznych warunków wzrostu, dostępności składników odżywczych, dojrzałości części roślin użytych do badań. Warunkiem stosowania ekstraktów roślinnych, 
podobnie jak i innych fitofarmaceutyków, jest stabilność składu chemicznego. Sposobem na uzyskanie powtarzalnej jakości surowca wydaje się być kontrolowana uprawa danej rośliny. Tak pozyskane rośliny rozmarynu zastosowano $\mathrm{w}$ badaniach Moreno i in. [2006], kłącza bergenii grubolistnej zebrano z plantacji na polu doświadczalnym [Kraśniewska i in. 2011].

Rozwiązanie to jest jednak rzadko stosowane w badaniach nad antybakteryjnymi właściwościami roślin. Źródłem surowca są najczęściej rośliny zbierane w środowisku naturalnym. W badaniach nad roślinami stosowanymi tradycyjnie w medycynie ludowej świeże części roślin zbierane są z naturalnych stanowisk np.: terenów wiosek plemiennych [Duraipandiyan i in. 2006], w różnych obszarach Palestyny, Libanu [Barbour i in. 2004], liście borówki czernicy ze stanowiska naturalnego w lesie mieszanym [Synowiec i in. 2011]. Zebrane rośliny były poddane klasyfikacji taksonomicznej przez botaników. Inni badacze [Mostafa i in. 2018] zakupili badane rośliny na lokalnym rynku. Często wykorzystywane są produkty handlowe w postaci soków, olejków, suszonych i zmielonych ziół. Nawet gotowe, handlowe soki z owoców żurawiny wielkoowocowej (Vaccinium macrocarpon), z owoców goji (Lycium barbarum), noni (Morinda citrifolia), rokitnika (Hippophae rhamnoides) wykazywały działanie antybakteryjne [Stobnicka i in. 2011], jednak sami autorzy zauważyli, że sposób przygotowania i różna kwasowość soków mogła przyczynić się do zróżnicowanego hamowania wzrostu drobnoustrojów. Stosowanie przetworzonego surowca stwarza ryzyko zafałszowania składu ekstraktu obcymi składnikami, utrudnia też porównywanie wyników badań uzyskanych przez różnych autorów.

\section{Wstępne przygotowanie surowca roślinnego}

Badania nad roślinami leczniczymi rozpoczynają się od czynności pre-ekstrakcji, czyli wstępnego przygotowania surowca, które jest ważnym etapem w procesie przetwarzania materiałów roślinnych. Celem tego etapu powinno być takie przygotowanie próbek, aby ograniczyć straty składników bioaktywnych zawartych w roślinach. Do badań przeciwdrobnoustrojowych wykorzystywany jest zarówno świeży, jak i suszony materiał rośliny. Wstępne etapy przygotowana surowca takie jak mielenie i suszenie także mogą wpływać na zawartość fitochemikaliów w końcowych ekstraktach. Wielu autorów, zwłaszcza wykorzystujących rośliny stosowane w etnomedycynie, przygotowywuje ekstrakty ze świeżych tkanek [Tiwari $i$ in. 2005]. Częściej jednak stosowane są suszone rośliny. Warunki suszenia oraz gatunek rośliny mają wpływ na zawartość substancji bioaktywnych. Zarówno temperatura, jak i czas suszenia mają duże znaczenie dla związków bioaktywnych, co wskazuje, że w każdym opisie metodyki należy precyzyjnie określić warunki doświadczenia. Na przykład, zawartość witaminy $\mathrm{C}$ w suszonych liściach stewii (Stevia rebaudiana) zmniejszyła się wraz ze wzrostem temperatury suszenia, chociaż nadal pozostała stosunkowo duża. Proces suszenia w temperaturach od 30 do $50^{\circ} \mathrm{C}$ spowodował istotny wzrost całkowitej zawartości związków fenolowych i flawonoidów ogółem, osiągając najwyższą wartość w obu przypadkach w liściach 
suszonych w temperaturze $40^{\circ} \mathrm{C}$, ale stężenie kwasu chlorogenowego zmieniało się pod wpływem temperatury suszenia. Aktywność przeciwutleniaczy mierzona metodą ORAC (oxygen radicae absorbance capacity - zdolność pochłaniania rodników tlenowych) wykazała również najwyższą wartość w temperaturze $40^{\circ} \mathrm{C}$, wskazując na korzystne warunki suszenia [Lemus-Mondaca i in. 2016]. Po procesie suszenia, w czosnku i pomidorach stwierdzono spadek zawartości związków fenolowych i antyoksydantów [Gumusay i in. 2015]. Leng i in. [2017] porównali całkowitą zawartość związków fenolowych, zdolność antyoksydacyjną świeżych, suszonych w temperaturze $60^{\circ} \mathrm{C}$ przez $3 \mathrm{~h}$ lub suszonych w temperaturze $180^{\circ} \mathrm{C}$ przez 10 min liści tamaryndowca (Tamarindus indica L.). Całkowita zdolność antyoksydacyjna i zawartość związków fenolowych ogółem w ekstrakcie była największa w przypadku liści suszonych w temperaturze $180^{\circ} \mathrm{C}$ [Leng $\mathrm{i}$ in. 2017]. Podobnie, porównując świeże i suszone liście Moringa oliefera, stwierdzono, że suszenie nie wpływa na zawartość związków fenolowych ogółem, ale podwyższa stężenie flawonoidów [Vongsak i in. 2013].

Wstępna obróbka materiału roślinnego (suchego lub świeżego) polega na jego rozdrobnieniu, co zwiększa szybkość i efektywność ekstrakcji. Jednak w opisach metodyki przygotowywania ekstraktów parametry techniczne tego etapu są zazwyczaj pomijane. Stopień rozdrobnienia materiału ma wpływ na wydajność ekstrakcji. Rozdrobnienie liści Anthocleista grandiflora zwiększało aktywność przeciwdrobnoustrojową ekstraktu, lepsze biostatyczne właściwości uzyskano po 5 min ekstrakcji bardzo drobno zmielonych liści o średnicy cząstek $10 \mu \mathrm{m}$ niż po $24 \mathrm{~h}$ wstrząsania wstępnie rozdrobnionego materiału [Eloff 1998]. Rozdrobnienie i mała wielkość cząsteczek zwiększają kontakt powierzchniowy pomiędzy próbkami i rozpuszczalnikami do ekstrakcji. Sproszkowanie i przesianie przez sito zwiększa homogenność próbki i powtarzalność ekstrakcji. Całkowita zawartość antyoksydantów w wodnych ekstraktach roślin leczniczych zależy od wielkości cząstek i czasu ekstrakcji. Wpływ czasu ekstrakcji zależał od gatunku rośliny, jednak ok. 5 min wystarczało do zapewnienia akceptowalnego stopnia, mniejsza wielkość cząsteczek zaś zwiększała zawartość antyoksydantów w ekstrakcie, w związku z czym autorzy zalecają stosowanie rozdrobnionego materiału o średnicy cząstek $0,2 \mathrm{~mm}$ [Gião i in. 2009]. Z wysuszonej rośliny Centellia azjatica przy pomocy młynu kulowego Planetary (PBM) uzyskano nanocząsteczki o średniej wielkości $501 \mathrm{~nm}$. Ekstrakcja substancji czynnej z nanoproszków była wydajniejsza o 82\% w porównaniu z techniką maceracji w 90-procentowym metanolu przez 3 dni [Borhan i in. 2013]. Rozmiar cząsteczek jest szczególnie ważny, gdy stosuje się ekstrakcję wspomaganą enzymatycznie. Również podczas ekstrakcji nadkrytycznej olejków zapachowych z nasion pietruszki wielkość cząstek (293 do $495 \mathrm{~nm}$ ) była jednym z istotnych parametrów wpływających na przebieg procesu [Louli i in. 2004].

Suszenie na powietrzu zwykle trwa długo - od kilku dni do kilku miesięcy, w zależności od rodzaju suszonych części roślin (np. liście lub nasiona). Próbki roślin, zwykle liście i łodygi, są pozostawiane w zacienionym, przewiewnym miejscu w temperaturze otoczenia. Podczas suszenia rośliny mogą ulec skażeniu 
i są narażone na niestabilne warunki temperaturowe. Suszenie w kontrolowanej temperaturze $\mathrm{w}$ piecu może być przydatne przy suszeniu roślin bogatych $\mathrm{w}$ olejki eteryczne. Najwyższą zawartość olejku eterycznego w werbenie cytrynowej (Lippia citriodora) otrzymano w wyniku suszenia w piecu w temperaturze $30^{\circ} \mathrm{C}$ [Shahhoseini i in. 2013]. Również inni autorzy stwierdzili, że rosnąca temperatura ogrzewania w piecu z 30 do $50^{\circ} \mathrm{C}$ obniżyła zawartość olejków eterycznych w liściach Laurus nobilis L. i Artemisia annua [Khangholi i Rezaeinodehi 2008, Sellami i in. 2011]. Liofilizacja ze względu na koszt procesu jest stosowana głównie do delikatnych, wrażliwych na temperaturę materiałów roślinnych. Sulfozwiązki aktywne mikrobiologicznie z cebuli i czosnku są termolabilne. Stężenie tych substancji w czosnku liofilizowanym było wyższe niż w suszonym na powietrzu lub w kuchence mikrofalowej [Farag i in. 2017].

\section{Metody wyodrębniania związków bioaktywnych z roślin w badaniach przeciwdrobnoustrojowych}

Podstawowym zjawiskiem zachodzącym podczas pozyskiwania substancji bioaktywnych z roślin jest proces ekstrakcji, czyli proces przeprowadzenia substancji z jednej fazy stałej lub ciekłej, w której substancja ta jest zawieszona lub rozpuszczona, do innej fazy ciekłej.

Skuteczny proces ekstrakcji biologicznie aktywnego związku z materiału roślinnego zależy w dużej mierze od rodzaju użytego rozpuszczalnika.

Tabela 2. Rozpuszczalniki stosowane do procesu ekstrakcji związków bioaktywnych [opracowano na podstawie: Azmir i in. 2013]

\begin{tabular}{|c|c|c|c|c|c|c|}
\hline Woda & Etanol & Metanol & Chloroform & Dichlorometanol & Eter & Aceton \\
\hline taniny & alkaloidy & terpenoidy & terpenoidy & terpenoidy & alkaloidy & $\begin{array}{c}\text { związki } \\
\text { fenolowe }\end{array}$ \\
\hline saponiny & taniny & saponiny & flawonoidy & & terpenoidy & \\
\hline terpenoidy & terpenoidy & taniny & & & kumaryny & \\
\hline & $\begin{array}{c}\text { związki } \\
\text { fenolowe }\end{array}$ & $\begin{array}{c}\text { związki } \\
\text { fenolowe }\end{array}$ & & & & \\
\hline
\end{tabular}

Prawidłowo dobrany rozpuszczalnik do ekstrakcji związków bioaktywnych z roślin powinien charakteryzować się niską toksycznością, niską temperaturą parowania, ułatwiać szybkie fizjologiczne wchłanianie ekstraktu, działać konserwująco i nie wchodzić w reakcje chemiczne ze składnikami. Produkt końcowy ekstrakcji może zawierać pozostałość rozpuszczalnika, dlatego rozpuszczalnik powinien być nietoksyczny i nie powinien wpływać na przebieg oznaczeń biologicznych [Ncube $i$ in. 2008]. We wstępnych badaniach nad właściwościami przeciwdrobnoustrojowymi roślin zazwyczaj stosuje się ekstrakcję wodą lub alkoholem, w dalszej kolejności - 
inne metody ekstrakcji. Woda jest uniwersalnym rozpuszczalnikiem, stosowanym do ekstrakcji produktów roślinnych o działaniu przeciwdrobnoustrojowym. Wybór rozpuszczalników w dużej mierze zależy od specyfiki docelowego związku bioaktywnego. Podczas ekstrakcji związków hydrofilowych stosuje się rozpuszczalniki polarne, takie jak metanol, etanol lub octan etylu. Do ekstrakcji związków lipofilowych wykorzystuje się najczęściej mieszaninę dichlorometanu i metanolu w stosunku 1 : 1 [Sasidharan i in. 2011]. W niektórych przypadkach ekstrakcja heksanem jest używana do usuwania chlorofilu [Cosa i in. 2006]. Ekstrakty roślinne przygotowane z zastosowaniem rozpuszczalników organicznych zazwyczaj mają wyższą aktywność przeciwdrobnoustrojową niż ekstrakty wodne [Parekh i in. 2005]. Substancje o właściwościach przeciwdrobnoustrojowych uzyskiwane z roślin najczęściej są związkami aromatycznymi lub nasyconymi związkami organicznymi, dlatego do wstępnej ekstrakcji stosuje się etanol lub metanol. Inne rozpuszczalniki stosowane do ekstrakcji to dichlorometan, aceton i heksan. Niektórzy autorzy używają kombinacji tych rozpuszczalników w celu uzyskania większej wydajności ekstrakcji [Sasidharan i in. 2011].

Stosunek objętości rozpuszczalnika do ilości próby również wpływa na wydajność ekstrakcji. W analizowanych pracach badacze stosowali bardzo różne proporcje rozpuszczalnika i próby. Za najlepszy uznano wariant ekstrakcji, w którym rozpuszczalnik został użyty w stosunku $10: 1$ (v/w) do masy suchej próbki [Green 2004]. Innym sposobem na lepszy dostęp rozpuszczalnika do tkanek jest homogenizacja tkanek roślinnych w rozpuszczalniku [Parekh i in. 2005]. Suszone lub mokre świeże części roślin są homogenizowane wraz z określoną objętością rozpuszczalnika i energicznie wstrząsane lub pozostawione na kilka godzin lub dłużej, po czym ekstrakt jest filtrowany. Niektórzy badacze stosują wirowanie w celu uzyskania ekstraktu [Vieitez i in. 2018]. Następnie filtrat może być suszony pod obniżonym ciśnieniem i ponownie rozpuszczony w rozpuszczalniku w celu określenia stężenia analitu lub wydajności ekstrakcji. Rodzaj rozpuszczalnika decyduje o wydajności ekstrakcji związków polarnych. Powszechnie stosowaną metodą jest seryjna ekstrakcja, polegająca na działaniu rozpuszczalnikami o zwiększającej się polarności. Do pierwszej ekstrakcji stosuje się heksan, a do kolejnej bardziej polarny rozpuszczalnik - metanol [Azmir i in. 2013].

Spośród licznych metod analitycznych, w badaniach nad właściwościami przeciwdrobnoustrojowymi wyciągów roślinnych najczęściej stosowana jest metoda ekstrakcji w układzie ciało stałe - ciecz (solid-liquid extraction - SLE), polegająca na przeniesieniu analitu z próbki stałej do fazy ciekłej. Możemy wyróżnić dwie grupy technik SLE: klasyczne i nowoczesne. Związki bioaktywne z materiałów roślinnych mogą być wyodrębniane przy zastosowaniu klasycznych metod, najczęściej stosowane są: maceracja, destylacja, ekstrakcja Soxhleta. Spośród technik nowoczesnych w badaniach przeciwdrobnoustrojowych właściwości ekstraktów roślinnych powszechnie stosuje się: ekstrakcję wspomaganą ultradźwiękami, ekstrakcję wspomaganą energią mikrofal, ekstrakcję za pomocą rozpuszczalnika pod zwiększonym ciśnieniem, przyśpieszoną ekstrakcję za pomocą rozpuszczalnika, 
ekstrakcję płynem w stanie nadkrytycznym, ekstrakcję enzymatyczną. Różnice w metodach otrzymywania wyciągów technikami klasycznymi zależą zazwyczaj od czasu ekstrakcji, użytego rozpuszczalnika, $\mathrm{pH}$, temperatury, wielkości cząstek tkanek roślinnych oraz stosunku objętości rozpuszczalnika do masy próbki.

\section{Maceracja i destylacja}

Macerację przeprowadza się w temperaturze pokojowej. Odpowiednio rozdrobnioną substancję roślinną zalewa się rozpuszczalnikiem i pozostawia do momentu wyrównania stężeń pomiędzy surowcem a rozpuszczalnikiem [Vieitez i in. 2018]. Czas maceracji jest zróżnicowany - od kilku godzin do kilku dni. Tradycyjna maceracja pozwala na skuteczną ekstrakcję związków bioaktywnych. Stwierdzono, że ekstrakty otrzymane w wyniku tradycyjnej maceracji z 75-procentowym roztworem etanolu charakteryzowały się wyższą zawartością związków antyoksydacyjnych, w tym związków fenolowych, niż po ekstrakcji nadkrytycznej dwutlenkiem węgla [Vieitez i in. 2018]. Jednak aktywność przeciwdrobnoustrojowa tych ekstraktów zależała od rodzaju użytych ziół i specyficznej wrażliwości bakterii. Podobny wynik porównania maceracji i nadkrytycznej ekstrakcji $\mathrm{CO}_{2}$ uzyskali inni badacze [Melo i in. 2014], wydajność ekstrakcji wzrastała wraz ze zwiększającą się polarnością rozpuszczalnika użytego do uzyskania ekstraktów.

Destylację stosuje się w celu oddzielenia substancji lotnych od mniej lotnych zanieczyszczeń lub do rozdzielenia mieszaniny kilku cieczy różniących się temperaturami wrzenia. Ciecz przeprowadzona jest w stan pary, a następnie po przejściu przez aparaturę chłodzącą skroplona [Wrzeciono i Zapruto 2001]. Do materiału roślinnego w celu uzyskania substancji niskocząsteczkowych, których temperatura wrzenia nie przekracza na ogół $200^{\circ} \mathrm{C}$ często stosuje się destylację prostą pod ciśnieniem atmosferycznym. Do substancji, które w temperaturach wrzenia ulegają rozkładowi stosuje się destylację próżniową - pod obniżonym ciśnieniem. W procesie destylacji z parą wodną (hydrodestylacji) można oczyścić substancje stałe lub ciekłe niemieszające się i niereagujące $\mathrm{z}$ wodą, ale lotne z parą wodną. W przypadku badań właściwości przeciwdrobnoustrojowych ekstraktów $\mathrm{z}$ roślin to częsta metoda referencyjna pozyskiwania olejków eterycznych [Lucchesi $\mathrm{i}$ in. 2004]. Z wodnej zawiesiny rozdrobnionej bazylii (Ocimum basilicum) metodą destylacji z parą wodną otrzymuje się olejek eteryczny z wydajnością od $1 \%$ do $1,5 \%$ masy surowca [Nurzyńska-Wierdak i in. 2012]. Z ziela hyzopu lekarskiego (Hyssopi officinalis) także tą metodą otrzymuje się olejek hyzopowy. Ma on działanie aseptyczne, przeciwwirusowe i antybakteryjne, jednak wydajność ekstrakcji wynosi $0,1-0,2 \%$, [Chouhan i in. 2017]. Otrzymywany z kwiatów lawendy lekarskiej (Lavandula officinalis) olejek ceniony jest w przemyśle kosmetycznym i ma także właściwości aseptyczne [Martucci i in. 2015]. Wydajność ekstrakcji w procesie destylacji z parą wodną wynosi około $0,8-1,8 \%$ masy surowca. Wadą tej metody jest długi czas procesu. Na przykład podczas otrzymywania olejku eterycznego z tymianku, aby osiągnąć temperaturę ekstrakcji $\left(100^{\circ} \mathrm{C}\right) \mathrm{i}$ tym samym uzyskać pierwszą kroplę olejku eterycznego, konieczne jest ogrzewanie 90 min dla 
hydrodestylacji, podczas gdy dla suchej ekstrakcji wspomaganej mikrofalami tylko przez 5 min. Jednak dłuższy czas ekstrakcji - 4,5 h - za pomocą hydrodestylacji daje porównywalną wydajność do uzyskiwanej w czasie 30 min suchej ekstrakcji mikrofalowej. Wydajność otrzymywania olejków eterycznych uzyskanych przez hydrodestylację wyniosła $0,028 \%$ dla bazylii, $0,095 \%$ dla mięty kruchej i $0,161 \%$ dla tymianku, a drugą wspomnianą metodą $0,029 \%$ dla bazylii, $0,095 \%$ dla mięty kruchej i $0,160 \%$ dla tymianku. Profil chemiczny ekstraktów uzyskanych tymi metodami różnił się. Znacznie mniejsze ilości związków utlenionych i większe ilości węglowodorów monoterpenowych stwierdzono w olejkach eterycznych roślin aromatycznych ekstrahowanych przez hydrodestylację [Lucchesi i in. 2004]. Podobnie zbliżona jest wydajność procesu nadkrytycznej ekstrakcji $\mathrm{CO}_{2}$ i hydrodestylacji podczas otrzymywania olejku eterycznego z rozmarynu, w pierwszej zastosowanej metodzie maksymalna wydajność wynosiła 2,53\% olejku eterycznego, a przy hydrodestylacji 2,35\% [Conde-Hernández 2016].

\section{Ekstrakcja Soxhleta}

Ekstraktor Soxhleta został zaprojektowany do izolacji lipidów, ale stosowany jest do pozyskiwania różnych związków bioaktywnych, które są termostabilne. Tą metodą nie pozyskuje się olejków eterycznych, gdyż odparowują one wraz z rozpuszczalnikiem. Ekstrakcja w aparacie Soxhleta jest także stosowana $\mathrm{w}$ badaniach porównawczych jako punkt odniesienia dla nowych alternatywnych metod ekstrakcji.

Skuteczność ekstrakcji w aparacie Soxhleta gwarantuje dokładne rozdrobnienie próbki, tak aby powierzchnia jej kontaktu z rozpuszczalnikiem była jak największa, co umożliwia szybką dyfuzję z tkanek roślinnych do rozpuszczalnika. Jeżeli wielkość cząsteczek wynosiła $0,4 \mathrm{~mm}$, to ekstrakcja tłuszczu z nasion oleistych trwała $2 \mathrm{~h}$ i przebiegała z 99-procentową wydajnością. Podobny efekt uzyskano dopiero po 12-godzinnej ekstrakcji, gdy wielkość cząstek wynosiła 2,0 mm [Luque de Castro i Garcia-Ayuso 1998]. Próbka poddawana jest ekstrakcji ciągłej, czas ekstrakcji wynosi zwykle kilka lub kilkanaście godzin. Zaletą tego typu ekstrakcji jest niewielka objętość zużywanego rozpuszczalnika, zatem ekstrakt zazwyczaj zawiera wysokie stężenie substancji czynnej. Otrzymany ekstrakt poddaje się dalszym procesom oczyszczania i wyodrębniania substancji aktywnej. Kluczowy dla ekstrakcji w aparacie Soxhleta jest dobór odpowiedniego rozpuszczalnika. Różne rozpuszczalniki pozwolą uzyskać z tej samej próbki różne składniki aktywne lub ich mieszaniny [Zarnowski i Suzuki 2004].

Najczęściej stosowany rozpuszczalnik do ekstrakcji olejów roślinnych to heksan. Ma wąski zakres temperatury wrzenia wynoszący około $63-69^{\circ} \mathrm{C}$ i doskonale rozpuszcza związki hydrofobowe. Wykorzystywane są także rozpuszczalniki takie jak izopropanol, etanol, węglowodory, $d$-limonen, a nawet woda [Hanmoungjai i in. 2000, Mamidipally i Liu 2004], a także mieszaniny rozpuszczalników, np. izopropanol i heksan [Li i in. 2004a]. Wyciągi uzyskane metodą ekstrakcji $\mathrm{z}$ heksanem miały silniejsze i szersze spektrum działania przeciwbakteryjnego niż ekstrakty metanolowe $i$ etanolowe [Adiguzel i in. 2005]. 


\begin{tabular}{|c|c|c|c|c|c|c|}
\hline 䒿 & 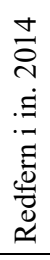 & 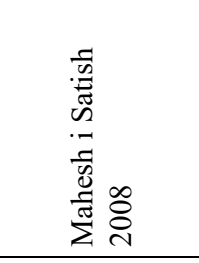 & 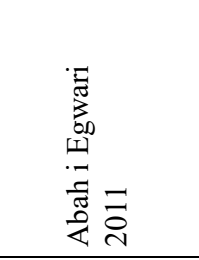 & 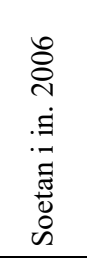 & 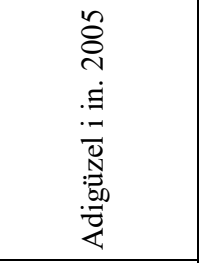 & $\begin{array}{l}n \\
\stackrel{n}{0} \\
\dot{\Xi} \\
\vdots \\
0 \\
0\end{array}$ \\
\hline 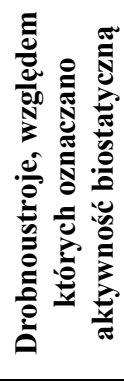 & 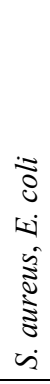 & 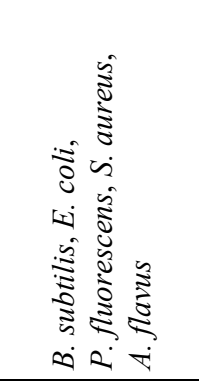 & 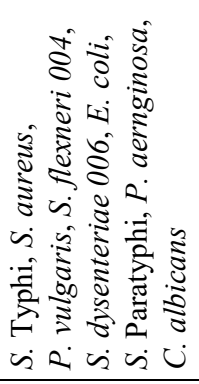 & 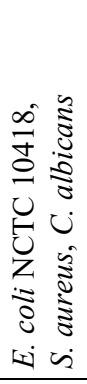 & 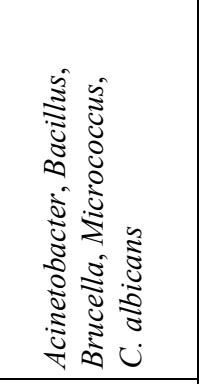 & 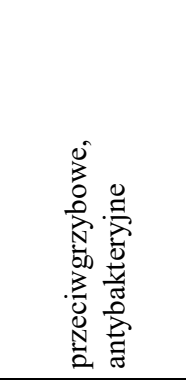 \\
\hline 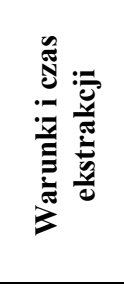 & $\stackrel{1}{0}$ & $\begin{array}{l}\frac{1}{\infty} \\
\stackrel{\infty}{+}\end{array}$ & $\begin{array}{l}1 \\
\infty \\
N \\
0 \\
N \\
0 \\
0 \\
0 \\
0 \\
0\end{array}$ & $\begin{array}{l}\text { a } \\
0 \\
N \\
N \\
N \\
0 \\
0 \\
0 \\
0 \\
0 \\
0 \\
0\end{array}$ & 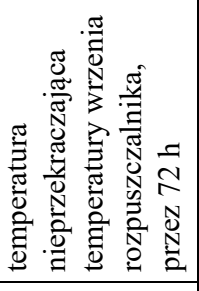 & 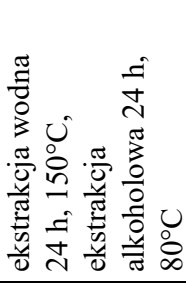 \\
\hline 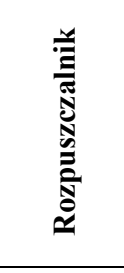 & $\begin{array}{l}\overrightarrow{0} \\
\text { J } \\
\text { J }\end{array}$ & $\begin{array}{l}\bar{\circlearrowright} \\
\text { 荧 } \\
\stackrel{\Xi}{\Xi} \\
\end{array}$ & 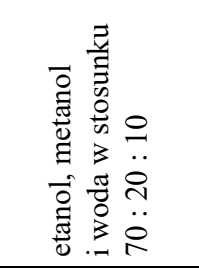 & 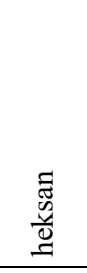 & 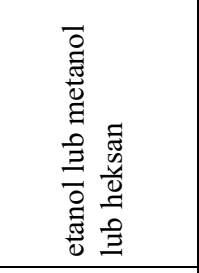 & 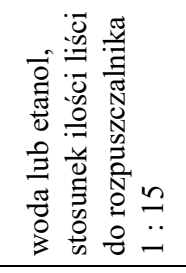 \\
\hline 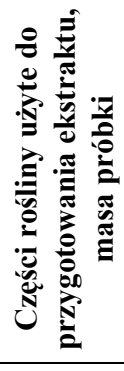 & 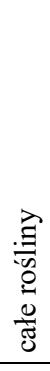 & 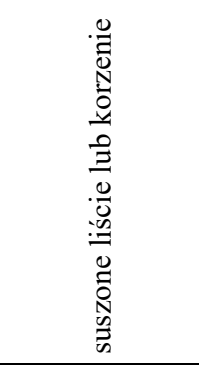 & 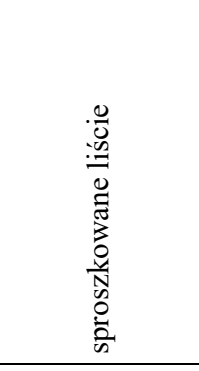 & 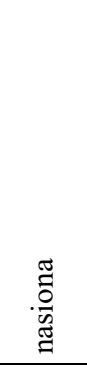 & 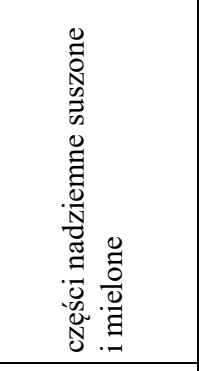 & 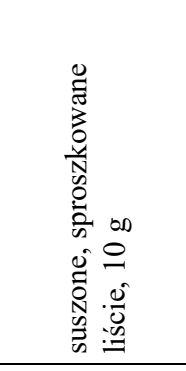 \\
\hline 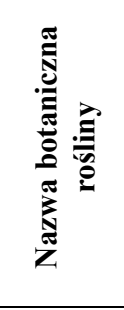 & 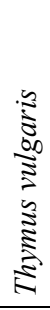 & 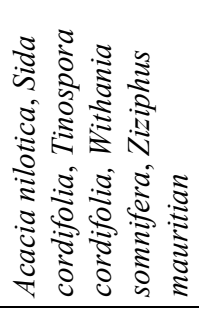 & 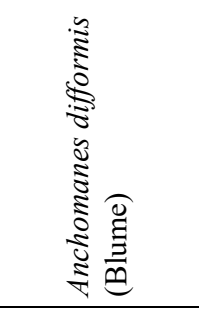 & 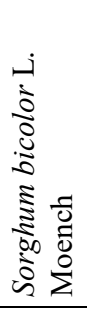 & 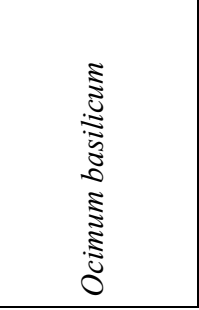 & 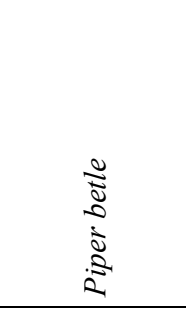 \\
\hline
\end{tabular}




\begin{tabular}{|c|c|c|c|}
\hline 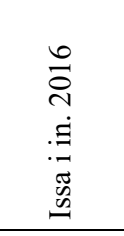 & 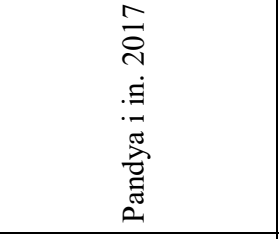 & 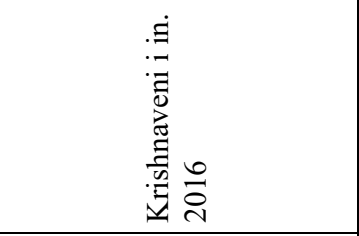 & 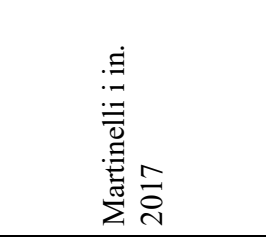 \\
\hline 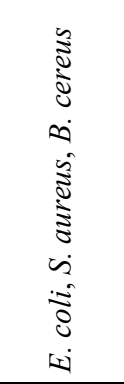 & 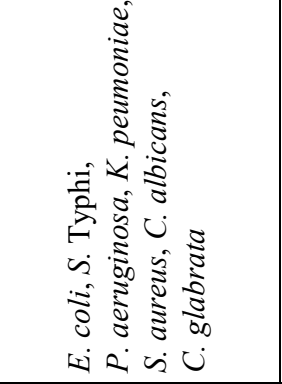 & 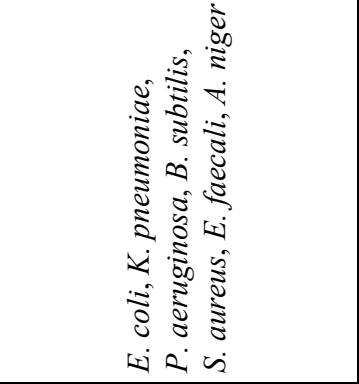 & 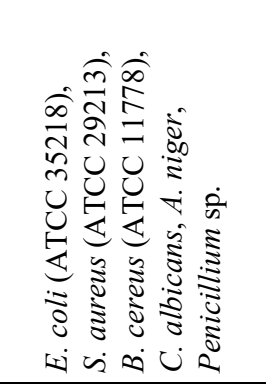 \\
\hline 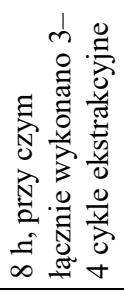 & 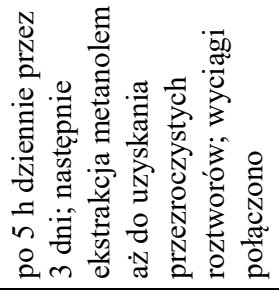 & 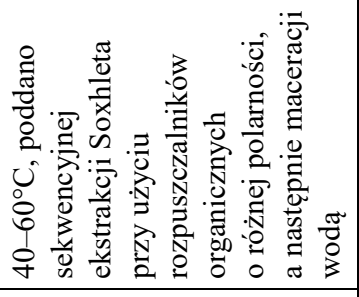 & \\
\hline 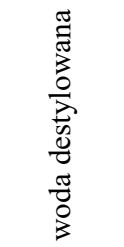 & 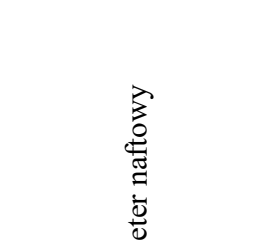 & 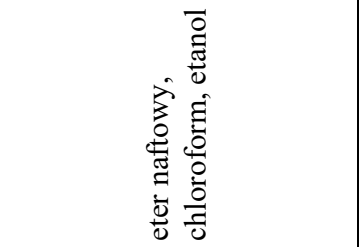 & 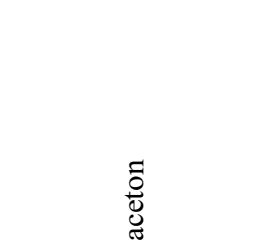 \\
\hline 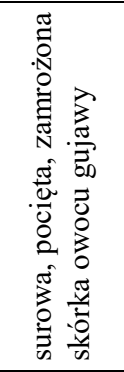 & 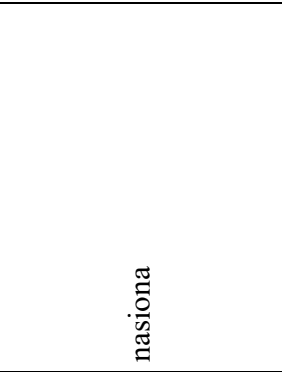 & 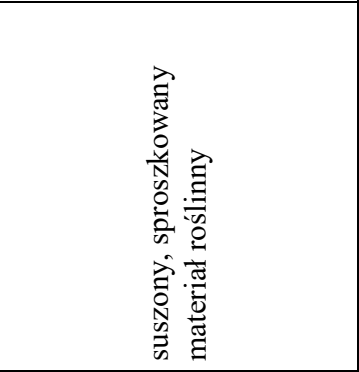 & 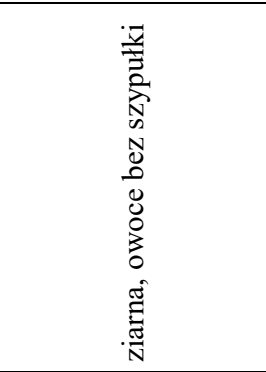 \\
\hline 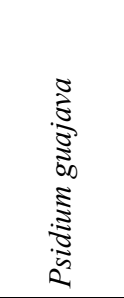 & 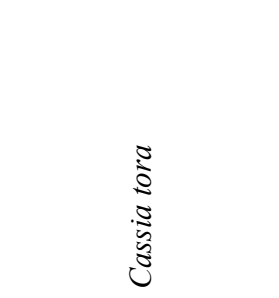 & 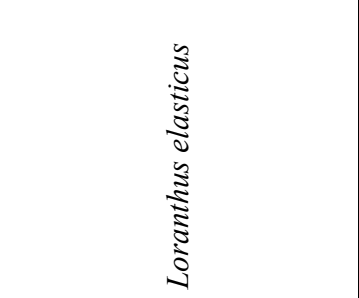 & 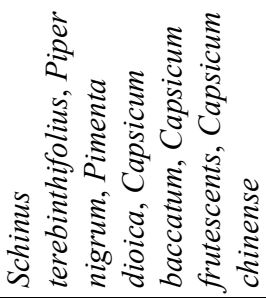 \\
\hline
\end{tabular}


Podczas ekstrakcji Soxhleta rozpuszczalnik jest zazwyczaj odzyskiwany przez odparowanie. Temperatura ekstrakcji i odparowania rozpuszczalnika również wpływa na jakość produktu końcowego. Mamidipally i Liu [2004] stwierdzili, że olej z otrębów ryżowych wyekstrahowany przy użyciu $d$-limonenu był ciemniejszy niż olej uzyskany z wykorzystaniem heksanu z powodu wyższej temperatury ekstrakcji i odparowywania $d$-limonenu. Temperaturę parowania rozpuszczalnika można zmniejszyć, stosując próżnię [Soetan i in. 2006, Mahesh i Satish 2008, Redfern $\mathrm{i}$ in. 2014].

\section{Nowoczesne techniki ekstrakcji substancji z roślin}

Konwencjonalne techniki ekstrakcji mają szereg ograniczeń, głównie czas ekstrakcji, zapotrzebowanie na kosztowny i wysokiej czystości rozpuszczalnik, odparowanie rozpuszczalnika, niska selektywność ekstrakcji i rozkład termiczny związków termolabilnych [Luque de Castro i Garcia-Ayuso 1998]. Dlatego też stosuje się techniki ekstrakcji wspomaganej ultradźwiękami (UAE - ultrasound-assisted extraction), z wykorzystaniem mikrofal (MAE - microwave-assisted extraction), ekstrakcję wspomaganą enzymatycznie, ekstrakcję wspomaganą impulsowym polem elektrycznym, ekstrakcję płynami nadkrytycznymi i ekstrakcję płynami pod ciśnieniem. Niektóre z tych technik uważa się za techniki przyjazne dla środowiska, ponieważ są one zgodne z normami ustalonymi przez Agencję Ochrony Środowiska USA [http://www. epa. gov/greenchemistry/; pubs/about_gc. html]. Wykorzystują one substancje chemiczne bezpieczniejsze dla środowiska, zużywają mniejsze ilości rozpuszczalników, są efektywniejsze energetycznie.

\section{Ekstrakcja wspomagana ultradźwiękami (UAE)}

Ultradźwięki to szczególny rodzaj fali dźwiękowej niesłyszalnej przez ludzi. Zazwyczaj są to drgania akustyczne o częstotliwości $20 \mathrm{kHz}$ do $100 \mathrm{MHz}$. Fala ultradźwiękowa, podobnie jak pozostałe fale, przechodzi przez medium i ulega kompresji i ekspansji, co przejawia się zmianami ciśnienia. Proces ten powoduje w cieczy zjawisko kawitacji polegające na powstawaniu, powiększaniu się i zapadaniu pęcherzyków parowo-gazowych. Może w nich powstać duża ilość energii w wyniku konwersji energii kinetycznej do termicznej. Mają one temperaturę około $500^{\circ} \mathrm{C}$, ciśnienie $1000 \mathrm{~atm}$, a szybkość ich ogrzewania i chłodzenia sięga powyżej $1010 \mathrm{~K} \cdot \mathrm{s}^{-1}$ [Stepnowski i in. 2010]. Zjawisko kawitacji zachodzi tylko w cieczach i matrycach zawierających ciecz. Energia ultradźwięków ułatwia ekstrakcję różnych substancji z matrycy roślinnej poprzez intensyfikację transferu mas. Podczas zapadania się pęcherzyków parowo-gazowych powstają wtórne fale akustyczne, które powodują uszkodzenie struktury tkanki roślinnej i zwiększają dostęp rozpuszczalnika do wydzielanych substancji. Na wydajność procesu UAE wpływają zawartość wilgoci w próbce, stopień zmielenia, rodzaj rozpuszczalnika, temperatura, ciśnienie, częstotliwość fali ultradźwiękowej. 


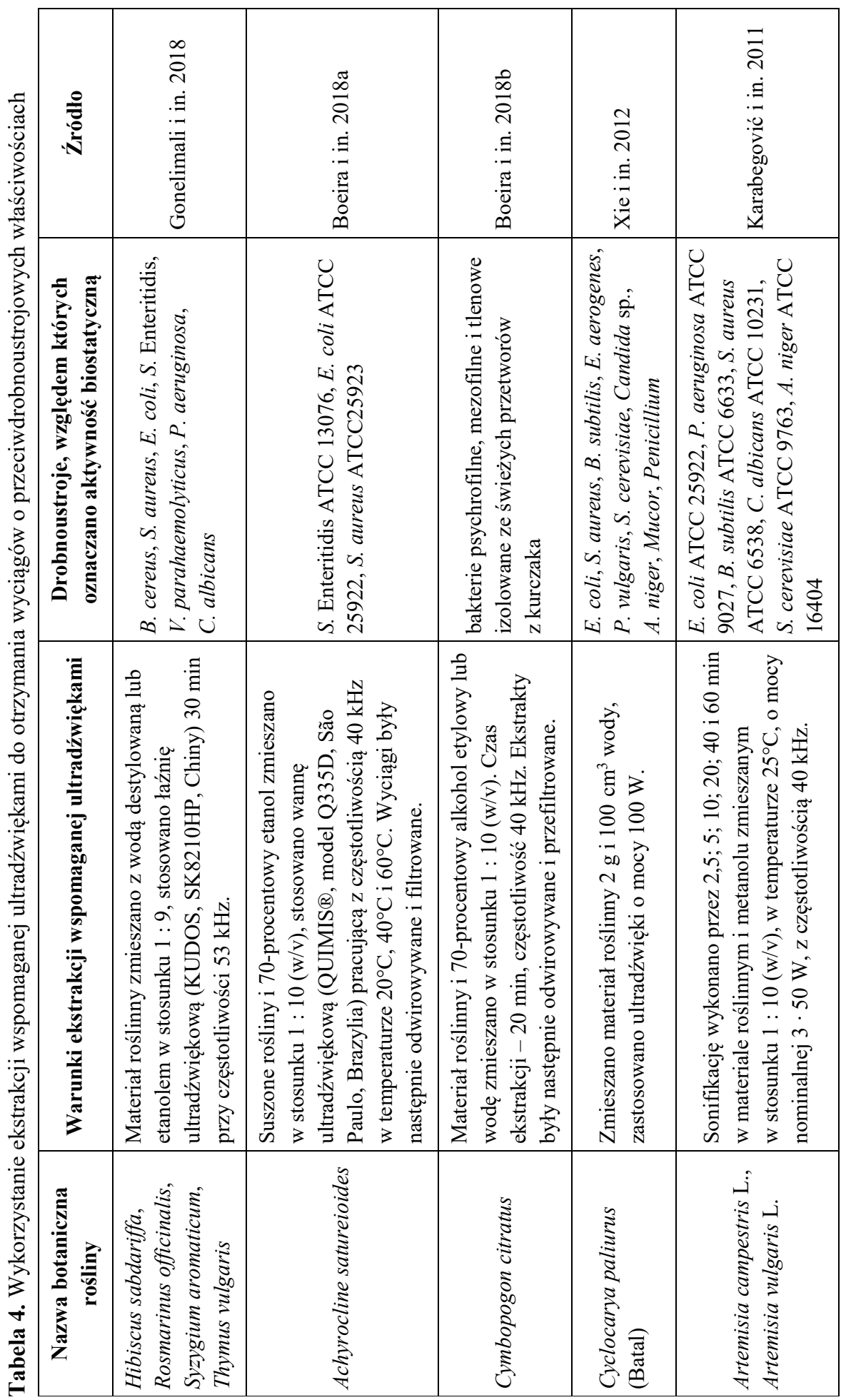




\begin{tabular}{|c|c|c|c|}
\hline 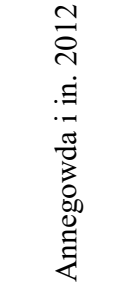 & 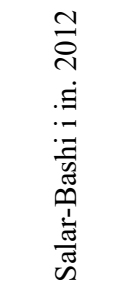 & 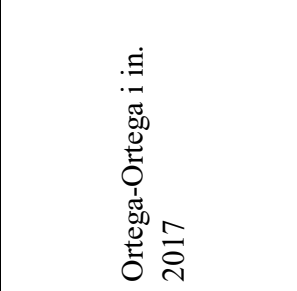 & 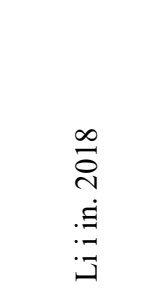 \\
\hline 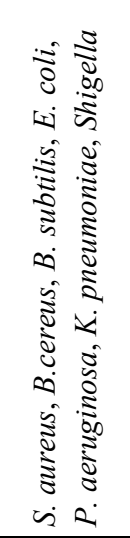 & 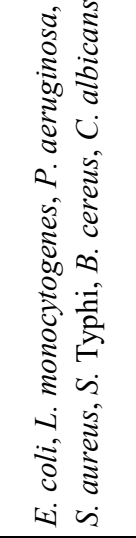 & 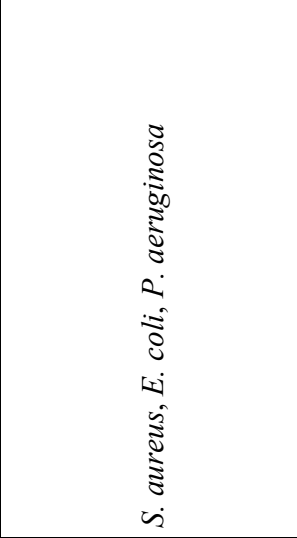 & 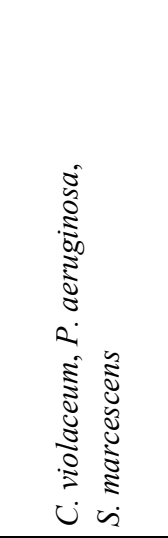 \\
\hline 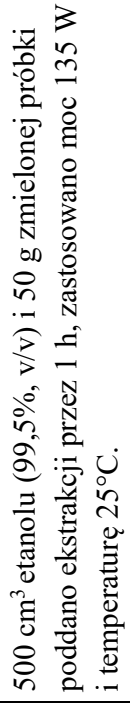 & 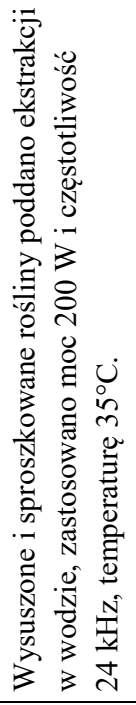 & 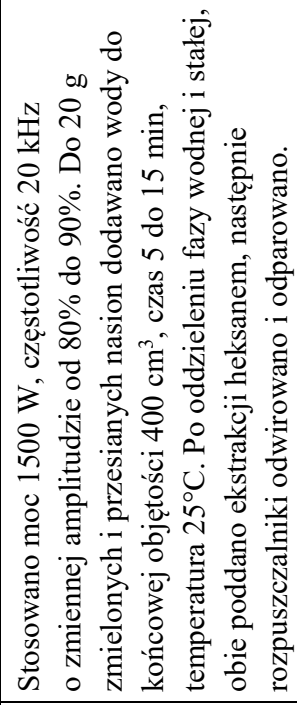 & 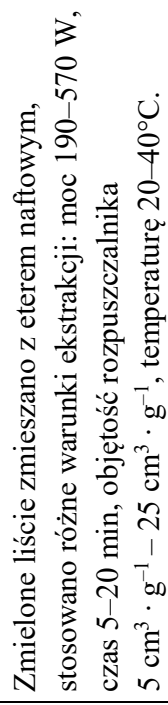 \\
\hline 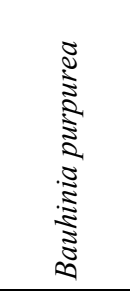 & 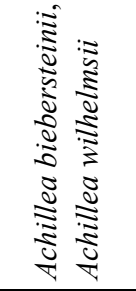 & 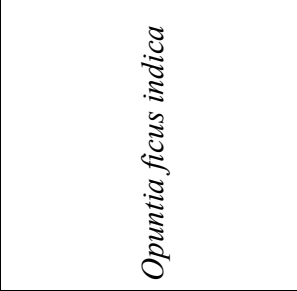 & 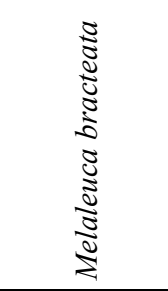 \\
\hline
\end{tabular}


Zalety UAE to m.in. skrócenie czasu ekstrakcji, oszczędność ilości rozpuszczalnika, obniżenie temperatury ekstrakcji nawet do temperatury pokojowej [Soria i Villamiel 2010]. Zastosowanie łaźni ultradźwiękowej umożliwia równoczesną ekstrakcję wielu próbek [Pingret i in. 2012]. Metoda ekstrakcji wspomaganej ultradźwiękami stosowana jest do otrzymywania: związków polifenolowych, tłuszczy, białka, związków aromatycznych, olejków eterycznych [Chemat i in. 2011]. Tę metodę można stosować do uzyskiwania termolabilnych substancji, a przy wykorzystaniu zestawu z chłodnicą zwrotną - do otrzymywania substancji lotnych [Pingret i in. 2014].

\section{Ekstrakcja wspomagana mikrofalami (MAE)}

Technikę MAE również uważa się za nowatorską, przyjazną dla środowiska naturalnego i korzystną ekonomicznie, gdyż może skrócić zarówno czas ekstrakcji, jak i zmniejszyć zużycie rozpuszczalnika [Bilgin i Sahin 2013, Chemat i in. 2015]. Ponadto MAE daje możliwość uzyskania produktów zgodnych z wymogami „zielonej chemii” o parametrach mieszczących się w normach środowiskowych, o wysokiej jakości i niskich kosztach wytworzenia [Putnik i in. 2016]. Na wydajność ekstrakcji MAE wpływa wiele czynników, np.: moc mikrofal, czas ekstrakcji, rodzaj i skład rozpuszczalnika, wielkość próbki, czas i liczba cykli ekstrakcji [Hayat i in. 2009, Li i in. 2011, 2013, Périno i in. 2016]. MAE sprzyja dyfuzji termolabilnych związków chemicznych z matrycy roślinnej. Skuteczność wspomagania ekstrakcji promieniowaniem mikrofalowym wynika ze sposobu przekazywania energii cieplnej. Energia promieniowania mikrofalowego dostarczana jest bezpośrednio cząsteczce związku chemicznego. Promieniowanie elektromagnetyczne w zakresie częstotliwości od $300 \mathrm{MHz}$ do $300 \mathrm{GHz}$ pochłaniane jest przez cząsteczki substancji polarnych budujących tkanki roślinne [Azmir i in. 2013]. Energia promieniowania mikrofalowego powoduje ruch jonów i polaryzację cząsteczek dipoli. Oscylujące pole elektryczne wymusza ruch drgający dipoli, co powoduje zderzenia z sąsiadującymi cząsteczkami i przekazanie energii. Jony w roztworze tkanek roślinnych umieszczonych w polu elektromagnetycznym przemieszczają się. Ciepło powstaje na skutek tarcia między poruszającymi się jonami a roztworem i rozchodzi się równomiernie w całej próbce, powodując jej dezintegrację. Mechanizm ekstrakcji MAE przebiega w trzech etapach [Alupului $i$ in. 2009]: oddzielenie rozpuszczalników od matrycy w podwyższonej temperaturze i ciśnieniu, dyfuzja rozpuszczalnika, uwalnianie substancji rozpuszczonych z matrycy do rozpuszczalnika [Azmir i in. 2013]. Również suszone rośliny zawierają molekuły wody pochłaniające promieniowanie mikrofalowe. Powstająca pod wpływem mikrofal wysoka temperatura powoduje odwodnienie celulozy, co prowadzi do obniżenia wytrzymałości mechanicznej tkanek [Delazar i in. 2012]. Energia elektromagnetyczna powoduje odparowanie wilgoci z matrycy roślinnej, powstające ciśnienie par wywiera znaczny nacisk na struktury komórkowe i dezintegruje tkanki. To z kolei ułatwia przenoszenie substancji rozpuszczonych z matrycy roślinnej do ekstraktu [Delazar i in. 2012]. 
Wybór rozpuszczalnika jest kluczowy dla tego typu ekstrakcji. Substancja ekstrahowana powinna dobrze rozpuszczać się w rozpuszczalniku. Rozpuszczalnik powinien być polarny tak jak np. woda, metanol, etanol, octan etylu, aceton. Ekstrakcję MAE z roślin często przeprowadza się w wodzie, gdyż jest ona podstawowym składnikiem tkanek wraz z zawartymi w niej polarnymi substancjami. Ekstrakcję $\mathrm{z}$ wodą przeprowadza się w układzie otwartym, przy ciśnieniu atmosferycznym, a temperatura procesu nie jest wysoka. W ekstrakcji MAE masa próbki waha się zazwyczaj od 2 do $20 \mathrm{~g}$, a objętość rozpuszczalnika do $30 \mathrm{~cm}^{3}$. Czas trwania ekstrakcji zwykle nie przekracza 30 min [Stepnowski i in. 2010].

W przeciwieństwie do konwencjonalnej metody Soxhleta wymagającej względnie dhugiego czasu (zazwyczaj 3-48 h), zastosowanie energii mikrofalowej do ogrzewania roztworu powoduje znaczne skrócenie czasu ekstrakcji (zazwyczaj do mniej niż $30 \mathrm{~min}$ ). MAE umożliwia również zmniejszenie ilości użytego rozpuszczalnika organicznego (zazwyczaj do poniżej $40 \mathrm{~cm}^{3}$ ) w porównaniu z objętością wymaganą w ekstrakcji Soxhleta [Eskilsson i Björklund 2000]. W badaniach nad optymalizacją procesu MAE najważniejsze dla materiałów roślinnych są: skład i objętość rozpuszczalnika, temperatura ekstrakcji i cechy matrycy. Badania kinetyczne wpływu tych warunków na ekstrakcję substancji leczniczych z liści rozmarynu i mięty pieprzowej wskazały, że w przypadku matrycy roślinnej zawierającej wodę jako składnik dielektryczny zastosowanie niepolarnego heksanu sprzyja szybkiej ekstrakcji olejków eterycznych. Zwiększenie wagi liści w stosunku do objętości heksanu w tym przypadku zwiększa efektywność konwersji energii mikrofalowej na ciepło. Natomiast gdy stosuje się rozpuszczalnik organiczny, który silniej absorbuje mikrofale (etanol i liście), bardziej efektywne ogrzewanie próbek można osiągnąć poprzez zwiększenie mocy mikrofal, ponieważ polarne cząsteczki etanolu a nie wody w liściach absorbują większość energii mikrofal [Chen i Spiro 1994]. Ekstrakcja z Radix puerariae metodą MAE zajęła tylko jedną minutę przy użyciu wody jako rozpuszczalnika, gdyż ta ciecz absorbuje energię mikrofal i przede wszystkim doskonale rozpuszcza wyodrębniany analit [Guo i in. 2001].

W przypadku ekstrakcji wodą można zwiększyć wydajność procesu, dodając odpowiednie związki zwiększające rozpuszczalność wydzielanej substancji. Wydajność ekstrakcji kwasu lukrecjowego z wodą lub wodą i etanolem zwiększono poprzez dodanie amoniaku lub soli potasowej w celu otrzymania lepiej rozpuszczalnych w wodzie związków: amonianu lukrecji i soli potasowej kwasu lukrecjowego [Pan i in. 2000]. Wysoka zawartość wilgoci w matrycach roślinnych sprzyja ekstrakcji MAE [Azmir i in. 2013]. W przypadku próbek roślin poddanych suszeniu, wstępne nawilżenie wodą poprawia efekt cieplny wywoływany przez mikrofale i poprawia wydajność ekstrakcji związków fenolowych [Alfaro $i$ in. 2003]. Ekstrakcja polifenoli i kofeiny z liści zielonej herbaty metodą MAE charakteryzowała się najwyższą wydajnością ekstrakcji po 4 min w porównaniu $\mathrm{z}$ ekstrakcją rozpuszczalnikiem $\mathrm{w}$ temperaturze pokojowej przez $20 \mathrm{~h} \mathrm{i} \mathrm{ekstrakcją}$ ultradźwiękami przez $90 \mathrm{~min}$ [Pan i in. 2003]. Zwiększanie mocy mikrofal może prowadzić do degradacji składników termolabilnych, potwierdzono to w przypadku ekstrakcji związków fenolowych [Chan i in. 2011]. 
Optymalne połączenie mocy mikrofal i temperatury sprzyja wysokiej wydajności ekstrakcji. W przypadku związków fenolowych z herbaty oolong ich całkowita zawartość zwiększała się wraz ze wzrostem temperatury ekstrakcji i mocy aż do $230 \mathrm{~W}$ [Tsubaki i in. 2010]. Wyższa temperatura podczas MAE wspomaga odwodnienie celulozy ściany komórkowej roślin i zmniejsza jej wytrzymałość mechaniczną, a to z kolei ułatwia dostęp rozpuszczalnika do związków chemicznych wewnątrz komórki. Uszkodzenia komórek podczas MAE potwierdzono w próbkach liści tytoniu przy pomocy skaningowego mikroskopu elektronowego [Zhou i Liu 2006]. Podobne zmiany w tkance roślinnej świeżej skórki pomarańczowej obserwowano również podczas ekstrakcji pektyn tą techniką [Kratchanova i in. 2004]. Matryca roślinna powinna być w całości zanurzona w rozpuszczalniku. W przypadku ekstrakcji konwencjonalnych wyższy stosunek objętości rozpuszczalnika do próbki może zwiększyć wydajność ekstrakcji. Objętość rozpuszczalnika w ekstrakcji MAE jest również czynnikiem krytycznym. Dane z literatury nie są jednak jednoznaczne, co do zwiększenia wydajności ekstrakcji w zależności od większej objętości rozpuszczalnika. W ekstrakcji MAE z Aretimisia annua L. uzyskano większą wydajność artemidyny dzięki większej ilości rozpuszczalnika [Hao i in. 2002]. Ekstrakcję flawonoidów z Saussurea medusa zwiększono przez zwiększenie objętości cieczy w stosunku do próbki - z $25: 1\left(\mathrm{~cm}^{3} \cdot \mathrm{g}^{-1}\right)$ na $100: 1\left(\mathrm{~cm}^{3} \cdot \mathrm{g}^{-1}\right)$ [Gao i in. 2006]. Zastosowanie dużej objętości rozpuszczalnika zwiększa koszty późniejszych etapów odparowywania i przygotowania próbki. Jednak w przypadku MAE nadmiar rozpuszczalnika w stosunku do próbki może spowodować niższe stężenie pozyskiwanego analitu. Podczas ekstrakcji pektyny ustalono, że mniejsza objętość rozpuszczalnika prowadziła do zwiększenia ilości uzyskanej pektyny przy $\mathrm{pH}=1$ [Wang $\mathrm{i}$ in. 2007]. W wielu doświadczeniach optymalny stosunek rozpuszczalnika i próbki wynosił jak $10: 1$ lub $20: 1$ [Pan i in. 2001, 2003, Li $\mathrm{i}$ in. 2004b, Talebi i in. 2004].

Podobnie jak w innych technikach ekstrakcyjnych czas jest parametrem, którego wpływ także musi być wzięty pod uwagę. Niezbędne jest przeprowadzenie odpowiednich badań nad optymalizacją czasu ekstrakcji w zależności od rośliny, wydzielanego analitu i używanego rozpuszczalnika. Dzięki wydłużeniu czasu ekstrakcji zwiększa się ilość analitów chociaż może też nastąpić ich rozkład. MAE jest szybką metodą ekstrakcji, wystarczy kilka lub kilkanaście minut. Stężenie polifenoli i kofeiny w ekstrakcie wzrastało aż do czwartej minuty procesu, a następnie zmniejszało się wraz z upływem czasu [Pan i in. 2003]. Największą, 92-procentową wydajność ekstrakcji artemizynin z Artemisia annua L. osiągnięto w ciągu 12 minut, natomiast przy wydłużaniu czasu procesu wydajność spadała [Hao $\mathrm{i}$ in. 2002], ponieważ nastąpiła degradacja termiczna tego związku. Rozpuszczalniki takie jak woda, etanol i metanol mogą osiągać wysokie temperatury pod wpływem długotrwałego oddziaływania mikrofal, co stwarza ryzyko rozkładu związków termolabilnych. Moc mikrofal i czas to dwa czynniki, które wpływają na proces ekstrakcji. Kombinacja niskiej lub umiarkowanej mocy mikrofal przy dłuższej 


\begin{tabular}{|c|c|c|c|c|c|}
\hline$\frac{O}{\overline{0}}$ & 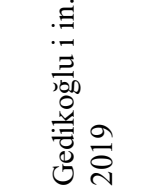 & 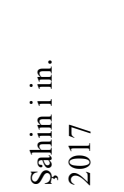 & 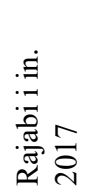 & $\begin{array}{l}: \Xi \\
: \overline{1} \\
: 0 \\
20 \\
\frac{0}{200} \\
\sum \frac{0}{2}\end{array}$ & 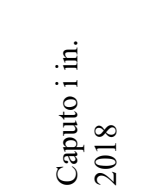 \\
\hline 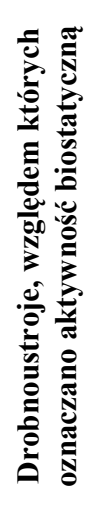 & 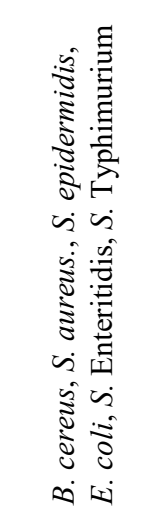 & 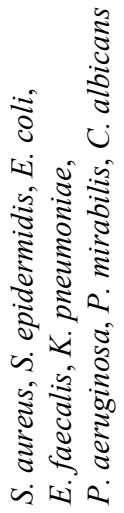 & 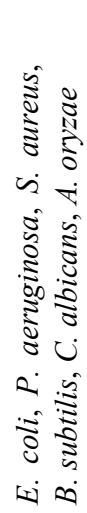 & 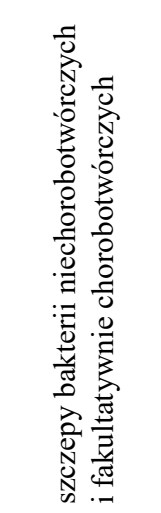 & 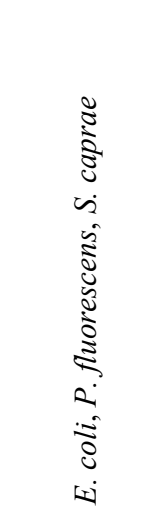 \\
\hline 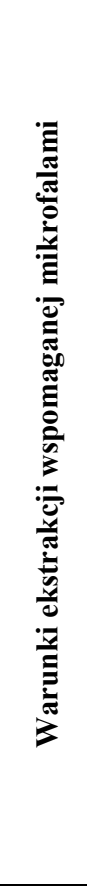 & 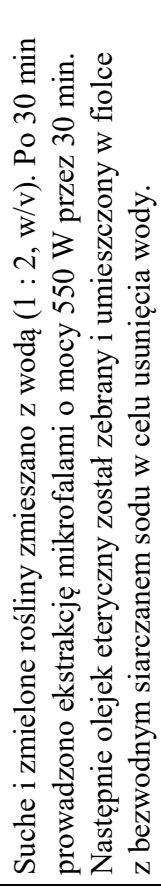 & 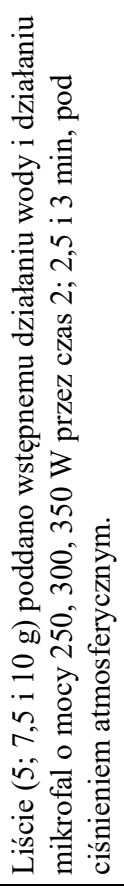 & 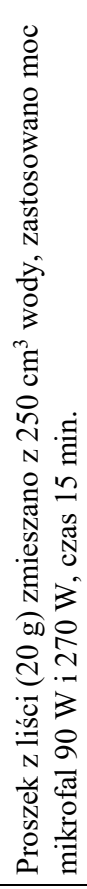 & 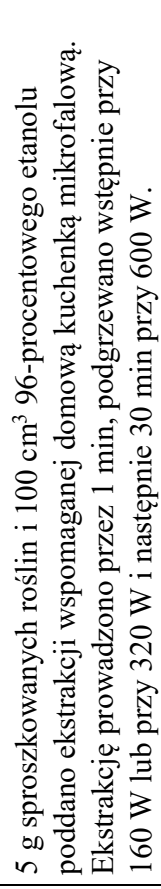 & 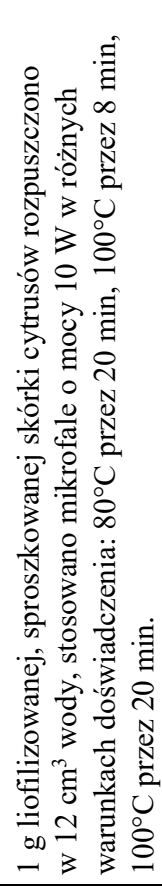 \\
\hline 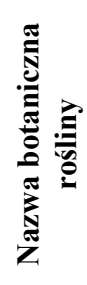 & 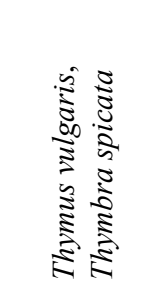 & $\begin{array}{l}\tilde{3} \\
\vdots \\
0 \\
\vdots \\
\vdots \\
\vdots \\
\vdots \\
0\end{array}$ & 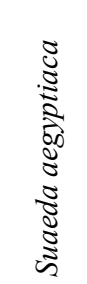 & 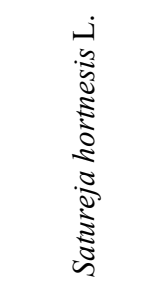 & 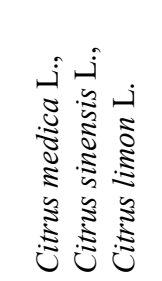 \\
\hline
\end{tabular}


ekspozycji na nie może zwiększyć wydajność procesu, co potwierdzono podczas ekstrakcji ginsenozydów metodą MAE w różnych warunkach mikrofalowych [Shu i in. 2003].

\section{Ekstrakcja wspomagana enzymami (EAE)}

Niektóre związki bioaktywne związane są w matrycach roślinnych wiązaniami chemicznymi i trudno je pozyskać w rutynowym procesie ekstrakcji przy użyciu rozpuszczalników. Zaproponowano wstępną obróbkę enzymatyczną materiału roślinnego w celu poprawienia wydajności ekstrakcji związków bioaktywnych. Stosowane enzymy rozkładają polisacharydową strukturę ściany komórkowej [Rosenthal i in. 1996]. Stosuje się dwa typy ekstrakcji wspomaganej enzymami (EAE - enzyme assisted extraction): ekstrakcja wodna wspomagana enzymami (EAAE - enzyme assisted aqueous extraction) i ekstrakcja enzymatyczna wspomagana tłoczeniem na zimno (EACP - enzyme assisted cold pressing) [Latif i Anwar 2009]. Do hydrolizy enzymatycznej stosuje się celulazy, amylazy i pektynazy. Poprawę wydajności ekstrakcji można osiągnąć, dodając mieszaninę enzymów pektynolitycznych i celulolitycznych w stosunku $2: 1$ do związków bioaktywnych [Maier i in. 2008] lub stosując do ekstrakcji rozpuszczalnik wodno-alkoholowy [Laroze $\mathrm{i}$ in. 2010]. EAAE jest uznawana za technologię przyjazną dla środowiska, ponieważ wykorzystuje wodę jako rozpuszczalnik zamiast organicznych substancji chemicznych. Na wydajność procesu wpływają różne czynniki: rodzaj i właściwości katalityczne enzymu, skład i stężenie mieszaniny reakcyjnej, wielkość cząstek materiałów roślinnych, czas hydrolizy [Niranjan i Hanmoungjai 2004]. Metody te stosuje się najczęściej w celu ekstrakcji olejów z nasion [Hanmoungjai i in. 2000, Sharma i in. 2002]. Olej ekstrahowany enzymatycznie zawiera większą ilość wolnych kwasów thuszczowych niż tradycyjnie ekstrahowany heksanem [Puri i in. 2012]. Metoda ta jest także stosowana do pozyskiwania związków fenolowych. Wykorzystano ją do otrzymywania tych związków z wytłoczyn z czarnuszki [Landbo i Meyer 2001], ze skórek owoców cytrusowych [Li i in. 2006], z odpadów winogronowych [Gómez-García i in. 2012]. Chandini i inni [2011] użyli enzymów taninazy i pektynazy niezależnie od siebie, aby uzyskać polifenole z czarnej herbaty. Maksymalny poziom ekstrakcji zaobserwowano, gdy użyto tylko taninazy. W innym doświadczeniu pozyskano flawonoidy z Ginkgo biloba, stosując celulazę z P. decumbens, która nie tylko degradowała ścianę komórkową, ale także zwiększyła rozpuszczalność ekstrahowanych związków w wodzie [Chen i in. 2010]. Ekstrakcja enzymatyczna znalazła też zastosowanie do ekstrakcji związków chemicznych z glonów, w przypadku których struktura i sztywność ściany komórkowej utrudnia pozyskiwanie wewnątrzkomórkowych związków bioaktywnych [Wang i in. 2010].

\section{Ekstrakcja cieczą pod ciśnieniem (PLE - pressurized liquid extraction)}

Inne stosowane nazwy dla tej metody to: przyspieszona ekstrakcja płynów, przyspieszona ekstrakcja rozpuszczalnikiem (ASE - accelerated solvent extraction) 


\begin{tabular}{|c|c|c|c|c|c|c|c|}
\hline 总 & 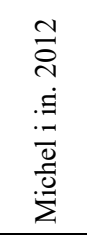 & 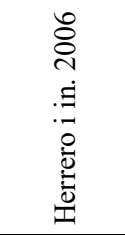 & 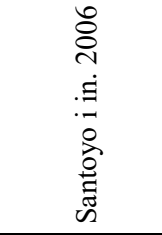 & 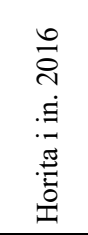 & 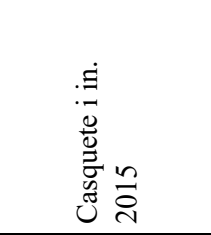 & 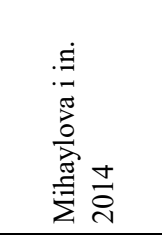 & 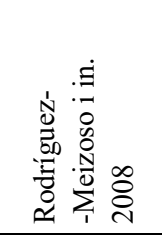 \\
\hline 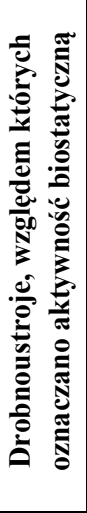 & 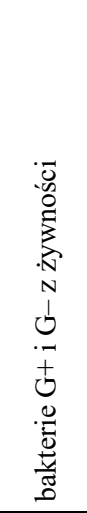 & 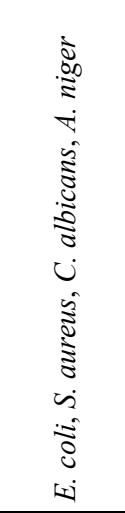 & 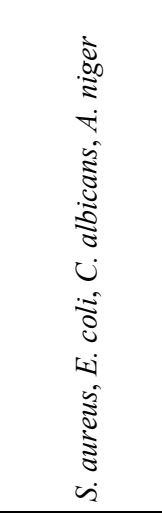 & 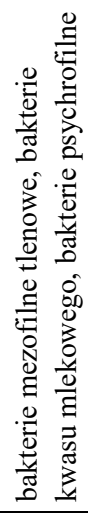 & 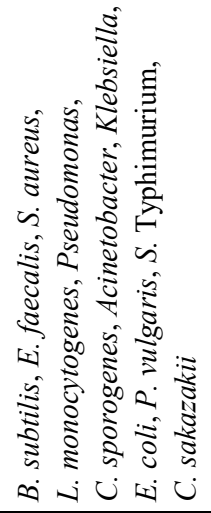 & 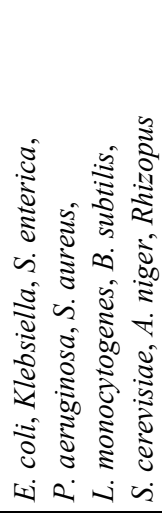 & 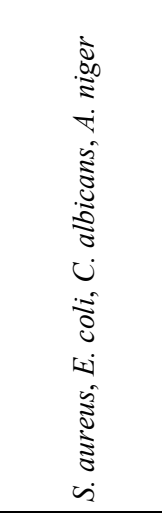 \\
\hline 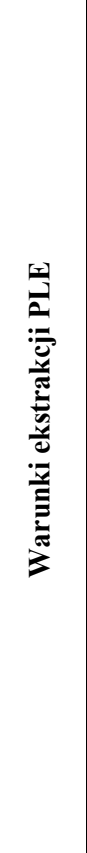 & 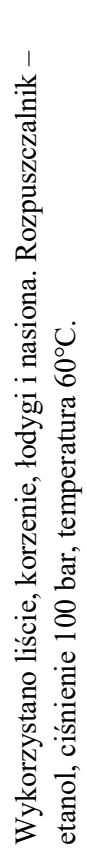 & 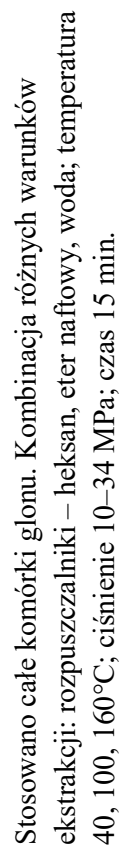 & 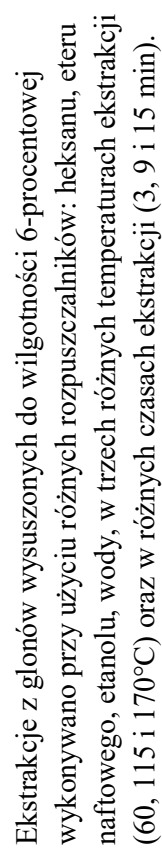 & 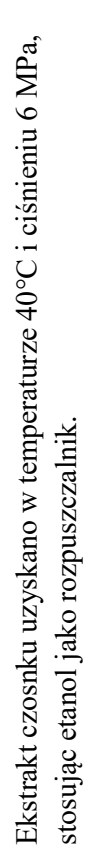 & 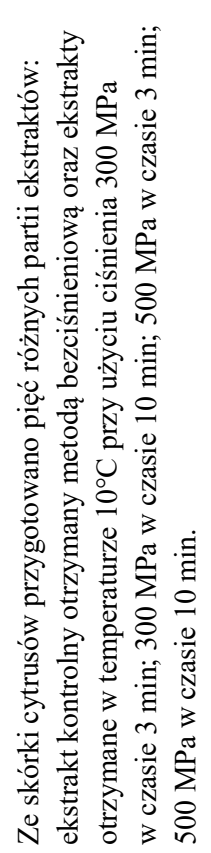 & 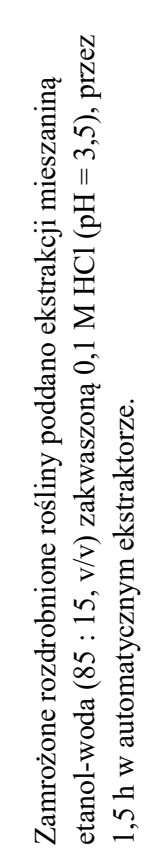 & 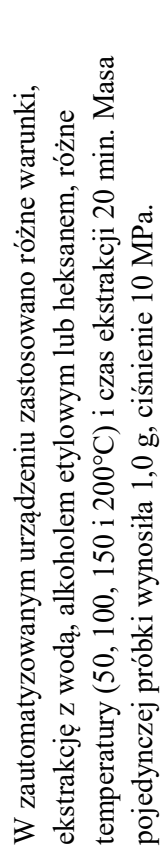 \\
\hline 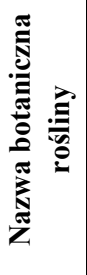 & 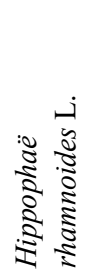 & 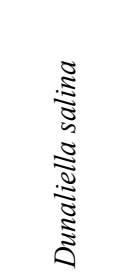 & 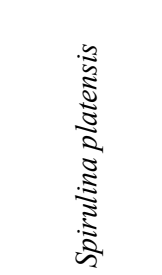 & 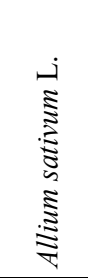 & 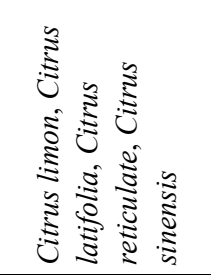 & 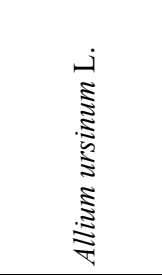 & 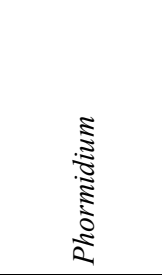 \\
\hline
\end{tabular}


[Nieto i in. 2010]. Metoda PLE polega na zastosowaniu wysokiego ciśnienia, tak aby utrzymać rozpuszczalnik w fazie ciekłej w temperaturze wyższej niż jego normalna temperatura wrzenia. Proces wymaga użycia specjalnie dostosowanych i odpornych na wysokie ciśnienie i temperaturę ekstraktorów. Stosuje się konwencjonalne rozpuszczalniki, proces przebiega $\mathrm{w}$ temperaturze $100-200^{\circ} \mathrm{C}$ przy ciśnieniu nawet do $20 \mathrm{MPa}$ [Carabias-Martinez i in. 2005].

Technika PLE wymaga niewielkich ilości rozpuszczalników, ponieważ kombinacja warunków - wysokiego ciśnienia i temperatury - zmienia właściwość cieczy, co sprzyja wydajności ekstrakcji [Mustafa i Turner 2011]. Powoduje również zerwanie słabych wiązań chemicznych (dipol-dipol, siły van der Waalsa i wiązań wodorowych), co zwiększa zdolność cieczy do rozpuszczania analitów, zwiększa szybkość dyfuzji i kinetykę przenoszenia masy analitów, a także zmniejsza lepkość i napięcie powierzchniowe rozpuszczalników [Wang i Weller 2006].

W metodzie tej stosowane są różne rozpuszczalniki, w tym woda. Dzięki możliwości zastosowania wody metoda ta jest przyjazna dla środowiska. Woda umożliwia wyodrębnianie z materiału roślinnego związków polarnych w niższej temperaturze ekstrakcji, a w wyższej temperaturze - związków niepolarnych, które w normalnych warunkach ciśnienia są nierozpuszczalne w wodzie [Liu i in. 2013]. Można także stosować do ekstrakcji rozpuszczalniki dwuskładnikowe jak woda-metanol lub etanol-woda, które są bardziej efektywne w mieszaninie niż czyste rozpuszczalniki organiczne [Mustafa i Turner 2011].

PLE z powodzeniem stosuje się do ekstrakcji związków bioaktywnych z różnych materiałów roślinnych, sprzyja temu automatyzacja procesu, krótki czas, mała zawartość rozpuszczalnika i minimalna wstępna obróbka próbki. Jest to często stosowana metoda do izolacji związków flawonowych [Ju i Howard 2003, Liu i in. 2013].

\section{Ekstrakcja płynem w stanie nadkrytycznym (SFE - supercritical fluid extraction)}

Metoda SFE ma wiele zalet. Jest selektywna i daje możliwość regulacji efektywności procesu przez zmianę parametrów, przyjazna dla środowiska ze względu na niewielkie zużycie rozpuszczalnika nadkrytycznego, a także szybka dzięki zastosowaniu zautomatyzowanej aparatury.

W metodzie SFE do ekstrakcji stosuje się rozpuszczalnik lub gaz w stanie nadkrytycznym (płyn nadkrytyczny), w warunkach ciśnienia i temperatury wyższych od jego parametrów krytycznych [Sharif i in. 2014]. Płyn w stanie nadkrytycznym wykazuje cechy zarówno cieczy, jak i gazu, cechuje go gęstość i zdolność rozpuszczania charakterystyczna dla rozpuszczalników ciekłych oraz ściśliwość, szybkość dyfuzji, lepkość i zdolność penetracji typowa dla gazów. Połączenie tych cech jest zaletą procesu ekstrakcji nadkrytycznej w stosunku do tradycyjnej ekstrakcji rozpuszczalnikami. Na przebieg SFE wpływa rodzaj użytego płynu nadkrytycznego, temperatura, ciśnienie, czas ekstrakcji, sposób kontaktowania ekstrahowanego materiału z płynem nadkrytycznym [Lang i Wai 2001]. Jako rozpuszczalniki w SFE używane są konwencjonalne rozpuszczalniki organiczne i ich mieszaniny, a także niektóre gazy: ditlenek węgla, podtlenek azotu, etylen, 


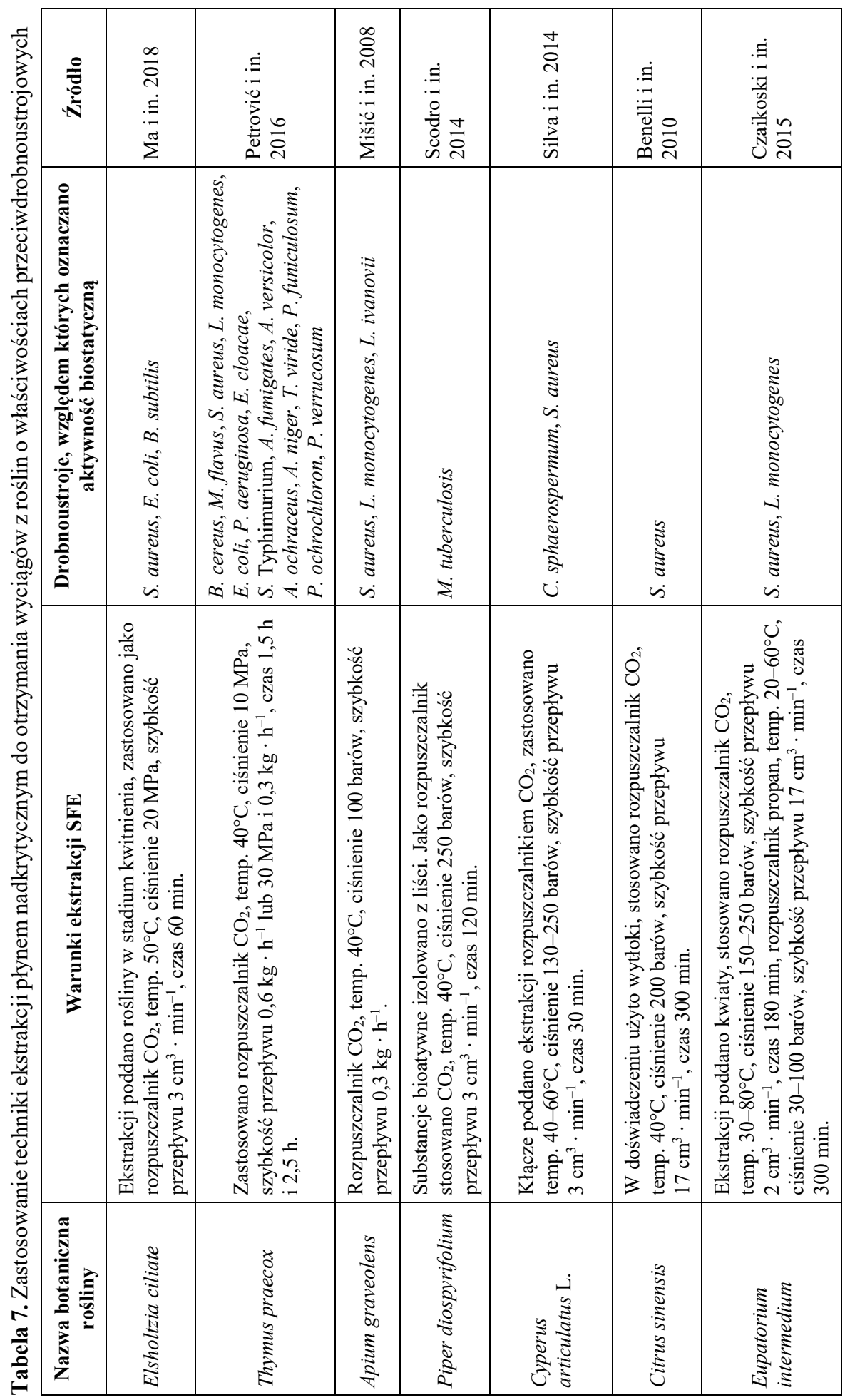




\begin{tabular}{|c|c|c|c|c|c|c|c|}
\hline \multicolumn{2}{|r|}{ ofpoxtz } & \multicolumn{3}{|c|}{ 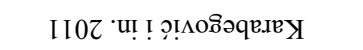 } & \multicolumn{3}{|c|}{ 乙I0乙 'U! ! врмовоәии } \\
\hline \multirow{5}{*}{ 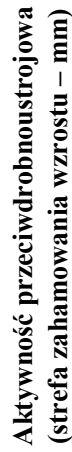 } & 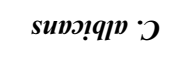 & $\stackrel{\Xi}{\sim}$ & $\stackrel{\sim}{i}$ & تُ & 迆 & تُ & تُ \\
\hline & snว.ın๊ $S$ & $\simeq$ & $\simeq$ & $\ddot{\dot{g}}$ & n & n & $n$ \\
\hline & $s ! l u q n s \cdot g$ & $\simeq$ & $\simeq$ & تُ & $\stackrel{n}{n}$ & $r$ & 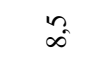 \\
\hline & psou!on.ıวp $\cdot d$ & $\simeq$ & $\simeq$ & نَّْ & 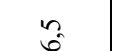 & $r$ & $a$ \\
\hline & $! 100 \cdot 3$ & $\simeq$ & $\simeq$ & تُ & $\approx$ & $r$ & $a$ \\
\hline \multirow{2}{*}{\multicolumn{2}{|c|}{ 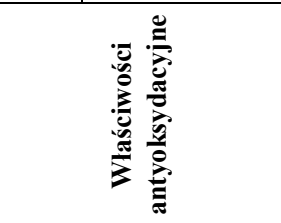 }} & ป & $\stackrel{\infty}{\sim}$ & $\stackrel{\sim}{\sim}$ & $\vec{m}$ & $\hat{i}$ & $\stackrel{m}{+}$ \\
\hline & & \multicolumn{3}{|c|}{ 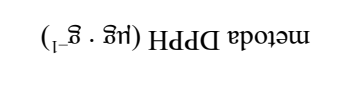 } & \multicolumn{3}{|c|}{ 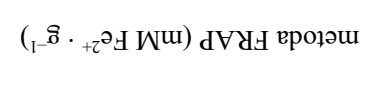 } \\
\hline & 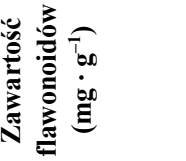 & $\stackrel{*}{\stackrel{*}{ٍ}}$ & 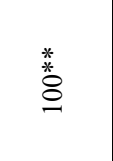 & 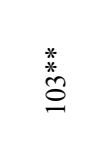 & $\stackrel{\stackrel{*}{*}}{\stackrel{*}{\sim}}$ & 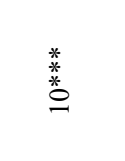 & 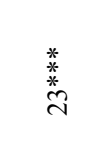 \\
\hline & 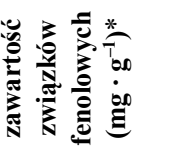 & 当 & $\vec{\beth}$ & $\cong$ & 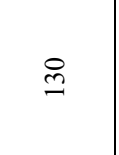 & $\Xi$ & 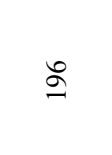 \\
\hline \multicolumn{2}{|c|}{ 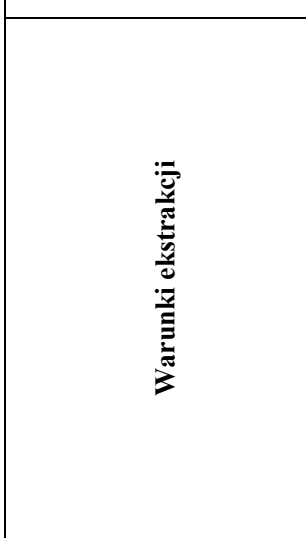 } & 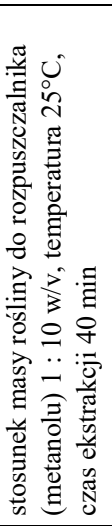 & 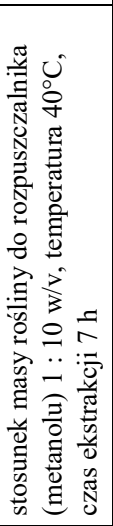 & 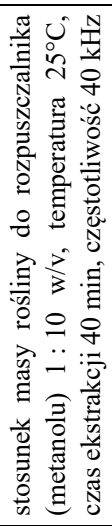 & 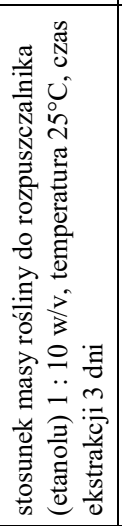 & 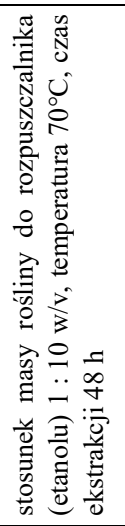 & 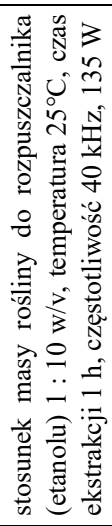 \\
\hline \multicolumn{2}{|r|}{ 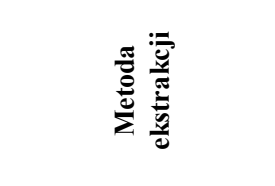 } & 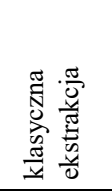 & 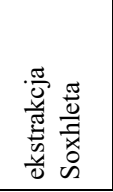 & 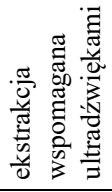 & 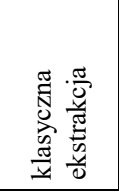 & 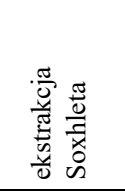 & 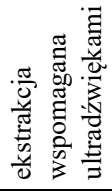 \\
\hline \multicolumn{2}{|r|}{ vu!!șoy } & \multicolumn{3}{|c|}{ 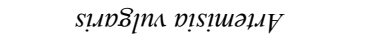 } & \multicolumn{3}{|c|}{${ }^{\top} \mathrm{T}$ pa.ındınd pı̣!чnpg } \\
\hline
\end{tabular}


etan, heksafluorek siarki, amoniak. Do ekstrakcji płynem w stanie nadkrytycznym najczęściej stosowany jest ditlenek węgla, charakteryzujący się niską temperaturę krytyczną $\left(31,1^{\circ} \mathrm{C}\right)$ oraz niskim ciśnieniem krytycznym $(73,8$ bar) [R.P. da Silva i in. 2016]. W celu poprawienia wydajności procesu do ekstrakcji związków polarnych i silnie związanych z matrycą używa się niewielkich ilości substancji polarnych jak metanol, etanol, aceton, acetonitryl oraz dichlorometan. Zmieniając paramety ekstrakcji, tj. temperaturę i ciśnienie, można selektywnie wydzielić różne anality. Gdy stosuje się ekstrakcję ditlenkiem węgla, obniżenie ciśnienia po zakończonym procesie pozwala na usunięcie gazu i zagęszczenie analitu. Jest to niewątpliwie zaletą SFE, gdyż można wyeliminować etap oczyszczania analitu i ryzyko utraty składników lotnych. SFE zazwyczaj wykonuje się w niskich temperaturach, dlatego często stosuje się ją do izolacji związków termolabilnych.

Ekstrakcja nadkrytyczna z matrycy roślinnej odbywa się zasadniczo w dwóch etapach: najpierw następuje rozpuszczenie związków chemicznych obecnych w strukturze tkanek roślinnych, a później ich rozdzielenie do cieczy nadkrytycznej. Matryca roślinna absorbuje nadkrytyczny rozpuszczalnik, struktury komórkowe pęcznieją, błony i kanały transbłonowe ułatwiają transfer analitu z matrycy wewnętrznej na powierzchnię matrycy. Rozpuszczone związki są następnie transportowane z powierzchni do nadkrytycznej cieczy i ostatecznie usunięte wraz $z$ rozpuszczalnikiem [R.P. da Silva $i$ in. 2016]. Proces wymaga kosztownej aparatury $i$ to ogranicza jego zastosowanie, zwłaszcza w skali laboratoryjnej [Khosravi-Darani 2010]. Na skalę przemysłową metoda SFE jest stosowana m.in. do ekstrakcji chmielu, kofeiny z kawy, obniżania stężenia alkoholu, usuwania $\beta$-karotenu, usuwaniu tłuszczu zwierzęcego z mleka, ekstrakcji aromatów [Janiszewska i Witrowa-Rajchert 2005]. SFE jest także stosowana do otrzymywania substancji o charakterze terapeutycznym, pozwala na izolację nowych nieznanych związków bioaktywnych [Sovilj i in. 2011].

W badaniach nad właściwościami przeciwdrobnoustrojowymi ekstraktów $\mathrm{z}$ roślin również stosowano tę metodę.

\section{Metody standaryzacji ekstraktów roślinnych stosowane w badaniach przeciwdrobnoustrojowych}

Jednym z podstawowych sposobów oceny procesu ekstrakcji jest obliczenie jej wydajności, która liczona jest jako ilość ekstraktu uzyskanego ze $100 \mathrm{~g}$ suszonego materiału roślinnego ( $\mathrm{g} \cdot 100 \mathrm{~g}^{-1}$ s.m.), może być także wyrażana w procentach. Wydajność ekstrakcji zależy od zastosowanej techniki. Zazwyczaj najwyższą wydajność ekstrakcji uzyskuje się w aparacie Soxhleta. Ekstrakcja Soxhleta z suchych tkanek Cissus quadrangularis jest bardziej wydajna $(3,6-5,9 \%)$ niż ze świeżych $(0,66-2,24 \%)$ [Murthy i in. 2003]. Na wydajność ekstrakcji wpływał także rodzaj stosowanego rozpuszczalnika, a także właściwości materiału biologicznego. Ekstrakcja suchego materiału roślinnego przebiegała $\mathrm{z}$ największą wydajnością $\mathrm{z}$ udziałem wody, w dalszej kolejności po zastosowaniu metanolu, octanu etylu 
i n-heksanu [Murthy i in. 2003]. Podczas otrzymywania olejków uzyskiwano podobną wydajność, stosując proces hydrodestylacji i destylacji suchej wspomaganej mikrofalami [Lucchesi i in. 2004], jak również proces nadkrytycznej ekstrakcji $\mathrm{CO}_{2}$ i hydrodestylacji [Conde-Hernández 2016].

Pomiar właściwości antyoksydacyjnych ekstraktów to kolejny sposób na porównywanie ich potencjalnej przeciwdrobnoustrojowej aktywności. Wiele związków o działaniu przeciwdrobnoustrojowym wykazuje właściwości antyoksydacyjne. W testach in vitro antyoksydanty zawarte w ekstraktach roślinnych dezaktywują wolne rodniki. Mechanizm tych reakcji polega na przeniesieniu atomu wodoru (HAT - hydrogen atom transfer), przeniesieniu pojedynczego elektronu (SET - single electron transfer) lub na kombinacji tych mechanizmów [Liang i Kitts 2014]. Z licznych metod pomiaru właściwości antyoksydacyjnych ekstraktów roślinnych często stosuje się metodę ABTS, DPPH, FRAP, ORAC (tab. 9).

Metody te mają specyficzne ograniczenia. Metody DPPH i ABTS są proste w wykonaniu i nie wymagają specjalnie przygotowanej próbki. Dodatkowo są to metody spektrofotometryczne, aparaturowo dostępne. Rodnik DPPH można zakupić komercyjnie, zaś rodnik ABTS trzeba wytwarzać z prekursora. W metodzie DPPH barwa roztworu po reakcji pomiędzy rodnikami a antyoksydantami jest żółta, co może wpływać na oznaczanie związków wykazujących absorbancję przy tym samym zakresie fal np. karetonoidów. Stosowany w metodzie FRAP kompleks $\mathrm{Fe}^{3+}-\mathrm{TPTZ}$ podlega redukcji przez związki, których potencjał redoks jest niższy od $0,70 \mathrm{~V}$, także te które nie są antyutleniaczami. Możliwe jest także ponowne utlenienie powstających jonów $\mathrm{Fe}^{2+} \mathrm{w}$ obecności $\mathrm{H}_{2} \mathrm{O}_{2}$ i tworzenie wtórnych rodników, co wpływa na jakość oznaczenia. Szczególnie problematyczne jest oznaczanie tą metodą próbek biologicznych, jak osocze krwi czy homogenaty zawierające białka, gdyż $\mathrm{pH}$ reakcji jest niskie i znacznie odbiega od $\mathrm{pH}$ fizjologicznego, a niektóre związki jak białka i tiole nie redukują kompleksu $\mathrm{Fe}^{3+}-\mathrm{TPTZ}$, co wpływa na zaniżenie pomiaru właściwości antyoksydacyjnych próbki. Metoda ORAC pozwala mierzyć właściwości przeciwutleniające związków hydrofilowych, jak i lipofilowych. Jest czuła i dokładna ze względu na stosowaną sondę fluorescencyjną. Oznaczanie aktywności antyutleniającej w modelowym układzie: kwas linolowy i $\beta$-karoten jest czasochłonne i wymaga przygotowania emulsji każdorazowo bezpośrednio przed oznaczeniem. Metody oznaczania właściwości antyoksydacyjnych mają względnie krótki czas wykonania i dają obiektywne rezultaty, jednak należy je stosować adekwatnie do specyfiki analizowanego produktu. Dodatkowo występują różne warianty danej metody i różne sposoby wyrażania aktywności antyoksydacyjnej, stosowane są różne wzorcowe antyoksydanty. Wszystko to komplikuje interpretację wyników. Brakuje norm wskazujących na użycie jednej uniwersalnej metody dla danego ekstraktu, dlatego też w wielu pracach potencjał antyoksydacyjny ekstraktów roślinnych oznacza się jednocześnie różnymi metodami.

Oprócz porównywania właściwości antyoksydacyjnych ekstraktów z roślin o potencjalnie przeciwdrobnoustrojowym działaniu w celu standaryzacji stosuje się 


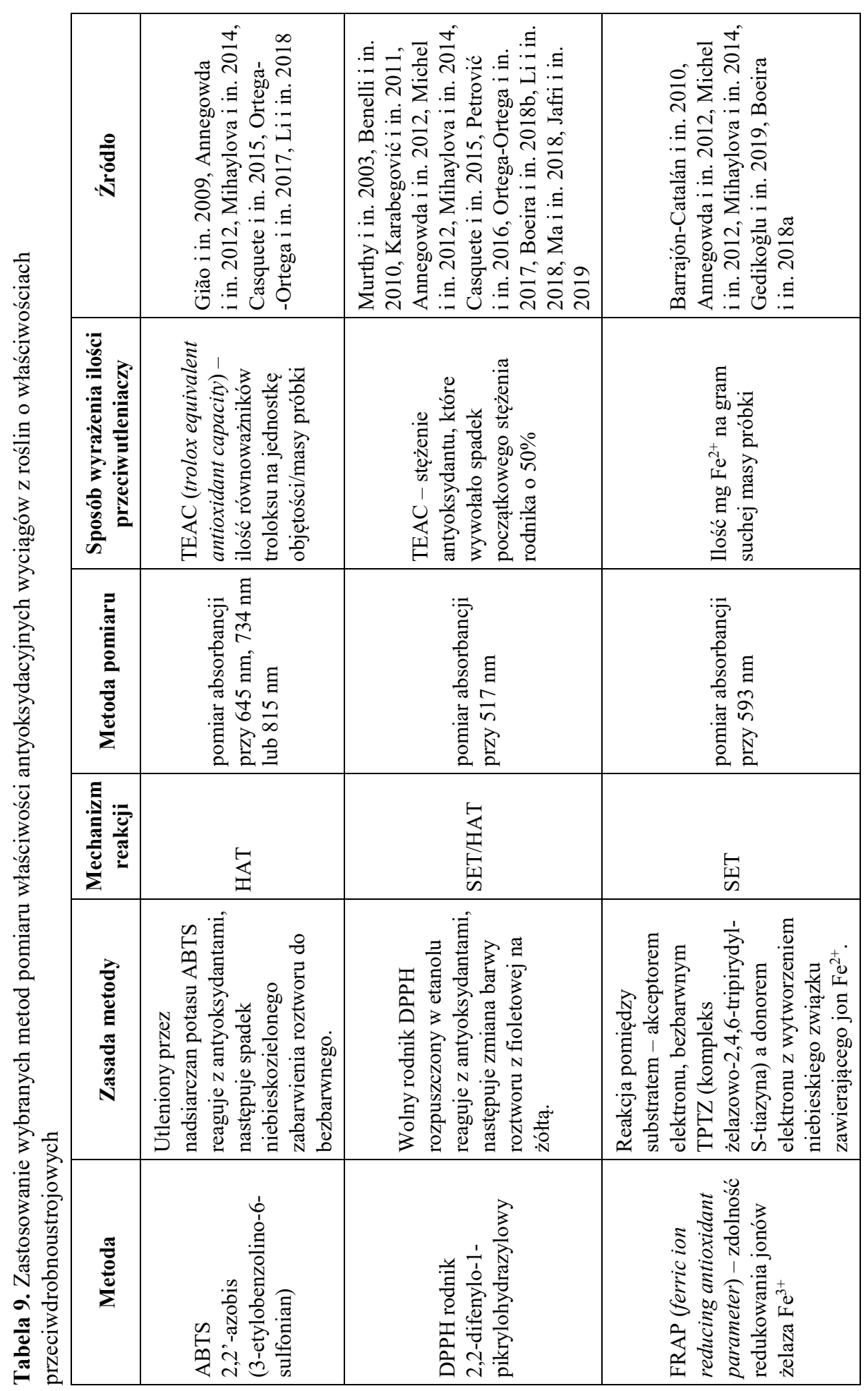




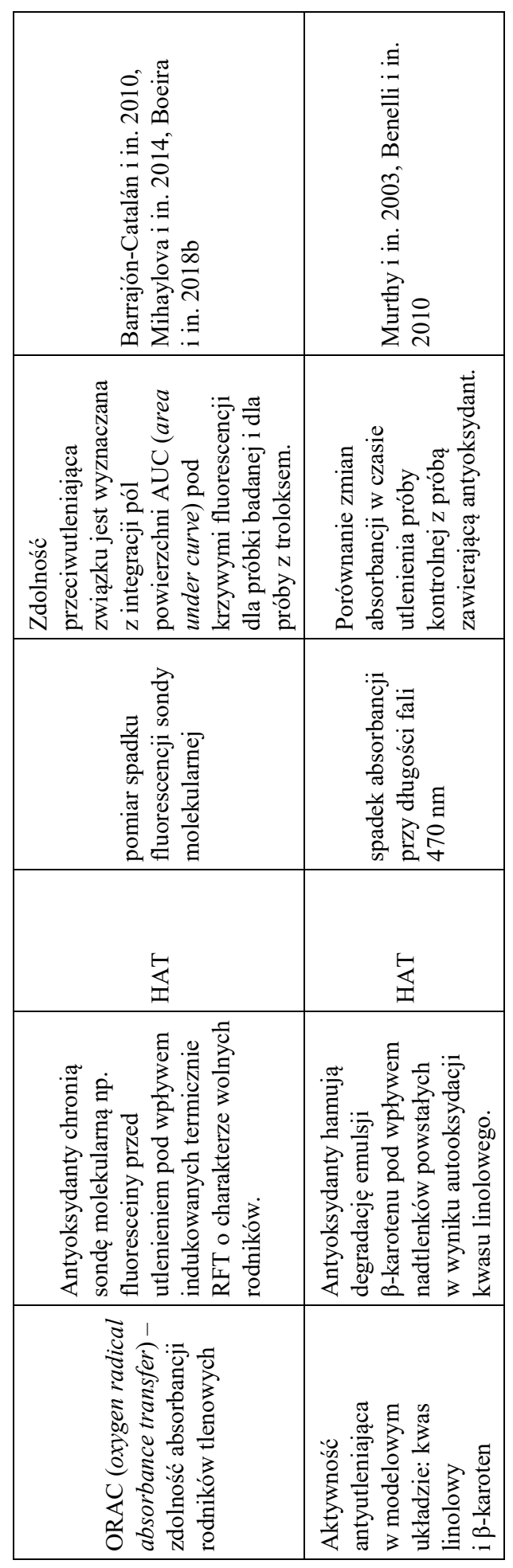


często oznaczanie stężenia substancji czynnych. Jednym z najczęściej stosowanych oznaczeń jest pomiar całkowitej zawartości związków fenolowych. Substancje zaliczane do tej grupy związków mają właściwości przeciwdrobnoustrojowe, mogą także hamować inne formy zagrożeń mikrobiologicznych jak czynniki wirulencji i tworzenie biofilmu. Metoda Folina-Ciocalteu [Lamuela-Raventós 2017] jest metodą spektrofotometryczną, opiera się na barwnej reakcji pomiędzy polifenolami a odczynnikiem zawierającym sole kwasów fosfowolframowego i fosfomolibdenowego [Everette i in. 2010]. W licznych publikacjach dotyczących przeciwdrobnoustrojowych właściwości ekstraktów przedstawiono oznaczenia tą metodą związków fenolowych [Michel i in. 2012, Mihaylova i in. 2014, Casquete $i$ in. 2015, Jafri $i$ in. 2019]. W zależności od rodzaju zawartych w ekstrakcie substancji aktywnych wykonywane są oznaczenia stężenia i profil chemiczny olejków eterycznych, alkaloidów, glikozydów, saponin, tanin [Jafri i in. 2019], często przy pomocy analizy instrumentalnej HPLC [Giao 2009, Michel i in. 2012, Gedikogu i in. 2015, Li i in. 2018]. Z wielu sposobów chemicznej charakterystyki ekstraktów stosowanych do badań przeciwdrobnoustrojowych jak do tej pory nie można wskazać grupy metod, które będą najbardziej adekwatne i pozwolą porównać wyniki uzyskiwane przez różne zespoły. Na aktywność przeciwdrobnoustrojową ekstraktów ma wpływ wiele czynników, poczynając od właściwości surowca, wybór techniki ekstrakcji, dobór odpowiednich metod analizy składu chemicznego. W publikacjach autorzy przedstawiają wyniki różnych testów i oznaczeń, aby ocenić właściwości antydrobnoustrojowe ekstraktów. 


\section{Substancje aktywne ekstraktów roślinnych i ich wpływ na drobnoustroje}

\section{Grupy metabolitów wtórnych o działaniu przeciwdrobnoustrojowym}

Oprócz tego, że rośliny wytwarzają podstawowe składniki odżywcze, takie jak białka, tłuszcze i węglowodany, potrzebne do podtrzymania funkcji życiowych, mogą też metabolizować inne związki, które są określane jako metabolity wtórne (MW). Pierwotnie uważano, że są to produkty uboczne metabolizmu roślin, które nie pełnią żadnej biologicznej funkcji. Obecnie wiadomo, że MW są to niskocząsteczkowe substancje, które służą roślinie do interakcji ze środowiskiem w adaptacji zarówno do warunków stresu biotycznego, jak i abiotycznego [Kusznierewicz 2017, Yang $i$ in. 2018]. Ze względu na to, że takie związki nie są kluczowe dla normalnego wzrostu, rozwoju i reprodukcji roślin, ale działają na nie ochronnie, zazwyczaj są syntetyzowane w roślinach ze względu na szczególne potrzeby, podczas gdy metabolity pierwotne spełniają ogólne biologiczne cele we wszystkich gatunkach. Każda z rodzin, rodzajów, a nawet gatunków roślin wytwarza charakterystyczną dla siebie mieszankę MW, które czasami są podstawą do taksonomicznego podziału roślin [Kabera i in. 2014]. Ze względu na biogenetyczną różnorodność i zróżnicowane struktury, istnieje kilka podziałów tych związków. Klasyfikacja ich może opierać się na strukturze chemicznej, obecności wybranych atomów lub rozpuszczalności w różnych substancjach oraz dróg biosyntezy [Adaszyńska i Swarcewicz 2013a, Kabera i in. 2014].

Jeden z podziałów metabolitów wtórnych zaproponował Croteau w 2000 r., dzieląc je na terpeny i terpenoidy, alkaloidy i związki fenolowe [Azmir i in. 2013]. Natomiast Kusznierewicz [2017] podaje podział ze względu na szlak biosyntezy, 
Tabela 10. Podział związków fenolowych i ich przykłady [opracowano na podstawie: Kusznierewicz 2017]

\begin{tabular}{|c|c|c|}
\hline \multicolumn{2}{|c|}{ Klasa } & Przyklady związków \\
\hline \multicolumn{2}{|c|}{$\begin{array}{l}\text { Kwasy hydroksybenzoesowe } \\
\text { i ich pochodne }\end{array}$} & $\begin{array}{l}\text { kwas galusowy, kwas protokatechowy, kwas rezorcynolowy, } \\
\text { kwas wanilinowy, kwas gentyzynowy, kwas elagowy }\end{array}$ \\
\hline \multicolumn{3}{|c|}{ Tyrosol i jego pochodne } \\
\hline \multicolumn{2}{|c|}{$\begin{array}{l}\text { Kwasy hydroksycynamonowe } \\
\text { i ich pochodne }\end{array}$} & $\begin{array}{l}\text { kwas kawowy, kwas p-kumarowy, kwas ferulowy, kwas } \\
\text { sinapinowy, kwasy chlorogenowe, kwasy szałwiowe }\end{array}$ \\
\hline \multicolumn{2}{|l|}{ Ksantony } & magniferyna \\
\hline \multicolumn{2}{|l|}{ Stilbeny } & $\begin{array}{l}\text { resweratrol, piceid, winiferyny, rapontygenina, piceatannol, } \\
\text { pterostilben }\end{array}$ \\
\hline \multirow{6}{*}{ Flawonoidy } & flawony & $\begin{array}{l}\text { apigenina, luteolina, diosmetyna, chryzyna, trycyna, synenstyna, } \\
\text { nobiletyna, bajkaleina, izoorientyna, witeksyna }\end{array}$ \\
\hline & flawonole & $\begin{array}{l}\text { kwercetyna, fizetyna, kempferol, moryna, herbacetyna, } \\
\text { robinetyna, mirycetyna, rutyna, izoramentyna }\end{array}$ \\
\hline & flawon-3-ole & $\begin{array}{l}(+) \text {-katechina, }(-) \text {-epikatechina, epigalokatechina, Galusa } \\
\text { epigalokatechiny, polimery flawon-3-oli }\end{array}$ \\
\hline & izoflawony & daidzeina, genisteina, glyciteina \\
\hline & flawanony & $\begin{array}{l}\text { naringenina, naringina, narirutyna, hesperytyna, hesperydyna, } \\
\text { taksifolina }\end{array}$ \\
\hline & antocyjanidyny & $\begin{array}{l}\text { cyjanidyna, pelargonidyna, delfinidyna, petunidyna, peonidyna, } \\
\text { malwidyna }\end{array}$ \\
\hline \multicolumn{2}{|l|}{ Lignany } & $\begin{array}{l}\text { sezamina, sezaminol, sezamolina, diglukozyd } \\
\text { sekoizolarycyrezynolu, pinorezynol, schizandryna }\end{array}$ \\
\hline \multicolumn{2}{|c|}{ Taniny hydrolizujące } & punikalagina, sangwina $\mathrm{H6}$, lambertianina $\mathrm{C}$, pedunkulagina \\
\hline \multicolumn{2}{|c|}{ Taniny skondensowane } & procyjanidyna $A_{1}$, procyjanidyna $B_{2}$, procyjanidyna $B_{6}$ \\
\hline
\end{tabular}

zawierający następujące grupy: związki fenolowe i polifenolowe, terpenoidy oraz niebiałkowe związki siarki i azotu [Kusznierewicz 2017]. W każdej z tych grup (tab. 10) są związki, wobec których udowodniono działanie przeciwdrobnoustrojowe. Inne, niezakwalifikowane powyżej, grupy związków o właściwościach przeciwdrobnoustrojowych to: kumaryny, fitosterole i glikozydy [Adaszyńska i Swarcewicz 2013b, Barbieri i in. 2017].

Niezależnym od powyższych podziałem roślinnych metabolitów wtórnych jest klasyfikowanie ich do fitoantycypin lub fitoaleksyn. Fitoantycypiny są to konstytutywne przeciwdrobnoustrojowe bariery chemiczne, natomiast fitoaleksyny są wytwarzane w wyniku ekspresji de novo enzymów wymaganych w ich szlakach metabolicznych [Jankowska i Swędrzyńska 2016]. Taki podział opiera się na dynamice syntezy cząsteczki przeciwdrobnoustrojowej i może być mylący 
Tabela 11. Podział terpenoidów i ich przykłady [opracowano na podstawie: Kabera i in. 2014]

\begin{tabular}{|l|l|}
\hline \multicolumn{1}{|c|}{ Terpeny/Terpenoidy } & \multicolumn{1}{c|}{ Przyklady związków } \\
\hline hemiterpeny & izopren, kwas izowalerianowy \\
\hline monoterpeny & limonen, eukaliptol, pinen \\
\hline seskwiterpeny & kwas abscysynowy \\
\hline diterpeny & gibereliny \\
\hline sesterpeny & \\
\hline triterpeny & lanosterol, skwalen, brassinosteroidy \\
\hline tetraterpeny & karotenoidy, likopen \\
\hline politerpeny & witamina E, cytokoniny \\
\hline
\end{tabular}

Tabela 12. Podział metabolitów wtórnych zawierających siarkę [opracowano na podstawie: Omar i Al-Wabel 2010, St-Gelais i in. 2015, Kusznierewicz 2017]

\begin{tabular}{|c|c|c|}
\hline \multicolumn{2}{|c|}{ Grupa metabolitów } & Przykłady związków \\
\hline \multirow{3}{*}{\multicolumn{2}{|c|}{ Glukozynolany }} & sinigryna \\
\hline & & glukonapina \\
\hline & & progoitryna \\
\hline \multirow{3}{*}{$\begin{array}{l}\text { Produkty rozkładu } \\
\text { glukozynolanów }\end{array}$} & \multirow{2}{*}{ izotiocyjaniany } & izotiocyjanian 3-metylotiopropylu \\
\hline & & izotiocyjanian 2-allilu \\
\hline & indole & indolo-3-karbinol \\
\hline \multirow{9}{*}{\multicolumn{2}{|c|}{ Związki zawierające grupę allilową }} & alliina \\
\hline & & allicyna \\
\hline & & metantiosulfinian allilu \\
\hline & & disiarczek diallilu \\
\hline & & trisiarczek diallilu \\
\hline & & trisiarczek allilometylowy \\
\hline & & S-allilomerkaptocysteina \\
\hline & & ajoen \\
\hline & & S-allilocysteina \\
\hline \multicolumn{2}{|l|}{ Dichromony } & paucinerwina \\
\hline
\end{tabular}


ze względu na to, że ta sama substancja może być fitoantycypiną w jednej roślinie i fitoaleksyną w drugiej. Może być również tak, że dana cząsteczka jest albo fitoantycypiną albo fitoaleksyną, w zależności od tego, w której części rośliny jest zlokalizowana [Grayer i Kokubun 2001].

Metabolity wtórne, charakteryzujące się właściwościami przeciwdrobnoustrojowymi, można dodatkowo podzielić na trzy grupy:

- związki chroniące powierzchnię rośliny przed infekcją (jest to pierwsza linia obrony),

- związki znajdujące się w wakuolach powiązane z systemem aktywacji hydrolitycznych enzymów (bardzo aktywne przy zranieniu tkanki, magazynowane są jako nieaktywne prekursory),

- fitoaleksyny - substancje obronne rośliny wytwarzane w odpowiedzi na atak (nie występują w roślinach o zdrowych, niezaatakowanych tkankach) [Meyer i in. 2002].

\section{Funkcje w roślinach oraz działanie przeciwdrobnoustrojowe wybranych grup metabolitów wtórnych}

Zakłada się, że rośliny ewoluowały razem z patogenami i dlatego wytworzyły skuteczne mechanizmy obronne. Metabolity wtórne w roślinie pełnią złożone, adaptacyjne i synergistyczne funkcje. Rośliny dzikie są bardziej odporne na szereg chorób wywołanych przez drobnoustroje niż rośliny uprawne. Takie przystosowanie się przypisywane jest synergistycznemu działaniu wielu łagodnie działających antybakteryjnych składników. Naturalnie rosnące rośliny wykazują umiarkowane działanie przeciwbakteryjne, nie niszczą patogenów całkowicie [Mundy i in. 2016]. Poniżej przedstawione są przykłady i niektóre mechanizmy działania przeciwdrobnoustrojowego różnych grup metabolitów wtórnych w roślinach.

\section{Związki fenolowe}

Związki fenolowe stanowią najważniejszą grupę fitochemikaliów. Zazwyczaj są odpowiedzialne za odcienie liści i kolory owoców [Bouyahya i in. 2017]. Substancje te odgrywają także kluczową rolę we wzroście roślin. Na przykład kaempferol lub kwercetyna ograniczają transfer polarnych związków auksynowych, hamując w ten sposób wzrost rośliny. Natomiast głównym zadaniem związków fenolowych, znajdujących się w zewnętrznych częściach roślin, jest ochrona przed szkodliwym działaniem promieniowania poprzez jego absorbowanie [Cheynier i in. 2013]. Wspólną cechą tych związków jest obecność w ich cząsteczce przynajmniej jednego pierścienia aromatycznego z 6 atomami węgla. Do tej grupy należą zarówno proste cząsteczki, jak np. kwasy fenolowe, jak i wysoko spolimeryzowane taniny [Bouyahya i in. 2017]. Przeciwbakteryjna aktywność związków fenolowych związana jest $z$ ich strukturą, a także rodzajem mikroorganizmu. Ze względu na duże zróżnicowanie 
w budowie tych związków ich działanie przeciwdrobnoustrojowe opiera się na różnych mechanizmach. Związki fenolowe mają zdolność do interakcji z błoną cytoplazmatyczną, ścianą komórkową, kwasami nukleinowymi oraz transportem energii, zmieniając lub hamując w ten sposób ich funkcje. Działają także poprzez denaturację enzymów bądź wiązanie witamin, minerałów czy węglowodanów, przez co te związki stają się niedostępne dla mikroorganizmów [Skroza i in. 2019].

\section{Kwasy fenolowe}

Kwasy fenolowe są bardzo rozpowszechnione w świecie roślinnym i występują m.in. w liściach, owocach, ziarniakach zbóż, oliwie z oliwek czy winie. Związki te w roślinach występują najczęściej w formie związanej. Na przykład kwasy hydroksycynamonowe często mają połączenia estrowe z kwasami hydroksylowymi lub glukozą, natomiast kwasy hydroksybenzoesowe najczęściej występują jako glikozydy [Gawlik-Dziki 2004]. Toksyczność kwasów fenolowych wobec drobnoustrojów ściśle powiązana jest z położeniem i ilością grup hydroksylowych w cząsteczce - im wyższa jest hydroksylacja, tym większa toksyczność [Bouyahya $i$ in. 2017]. Jest ona także zależna wprost proporcjonalnie od długości łańcucha alkilowego [Merkl i in. 2010]. Kolejną zależnością jest to, że oligomery wykazują większą aktywność przeciwdrobnoustrojową niż odpowiadające im monomery kwasu fenolowego [Elgir i in. 2008]. Mechanizmy odpowiedzialne za przeciwdrobnoustrojowe działanie kwasów fenolowych, takie jak hamowanie ich enzymów, mogą być wynikiem ich reakcji z grupami sulfhydrylowymi lub niespecyficznych interakcji z białkami [Bouyahya i in. 2017].

Chociaż poszczególne kwasy fenolowe wykazują pewne działanie przeciwdrobnoustrojowe, wielu naukowców dowiodło, że jest ono niższe niż np. flawonoidów. Jednym z możliwych wyjaśnień tego zjawiska jest niższa polarność kwasów fenolowych, przez co słabiej dyfundują do środowiska [Skroza i in. 2019].

\section{Stilbeny}

Najważniejszą funkcją stilbenów jest ich działanie przeciwdrobnoustrojowe, dlatego związki te zaliczane są do fitoaleksyn. Działają także odstraszająco na zwierzęta roślinożerne, mają właściwości allelopatyczne oraz antyoksydacyjne. Wytwarzane są w roślinie w niewielkich ilościach. Na aktywację ich biosyntezy mają wpływ infekcje, uszkodzenia tkanki, promieniowanie UV, ozon i jony glinu [Kozłowska i Czekała 2017].

Najszerzej przebadanym przedstawicielem tej grupy metabolitów wtórnych jest resweratrol - substancja powszechnie występująca m.in. w owocach winorośli czy orzeszkach ziemnych. Wyniki wielu badań udokumentowały przeciwdrobnoustrojowe działanie tego związku. W badaniach własnych Skroza i in. [2019] wykazali, że resweratrol działał silnie przeciwko bakteriom Gram-dodatnim (S. aureus i B. cereus) i nieco słabiej przeciwko bakteriom Gram-ujemnym (E. coli i $S$. Infantis), co potwierdziło wyniki innych badaczy [Skroza i in. 2019]. Resweratrol 
wpływa także na ograniczenie rozwoju $H$. pylori oraz wirusa $H$. simplex [MikułaPietrasik i in. 2015].

Pterostilben - eter metylowy resweratrolu - wykazuje działanie przeciwgrzybiczne i w porównaniu z resweratrolem silniej hamuje kiełkowanie sporangii mączniaka rzekomego winorośli. Lee i in. [2017] udowodnili, że pterostilben wykazuje działanie bakteriobójcze wobec bakterii $S$. aureus i E. coli, chociaż wcześniejsze publikacje informowały jedynie o działaniu bakteriostatycznym [Lee $i$ in. 2017]. Ren $i$ in. [2019] również wykazali w swoich badaniach przeciwbakteryjne działanie pterostilbenu wobec wskazanych bakterii, opisując jednocześnie jego mechanizm. Związek ten indukuje stres oksydacyjny, wytwarzając wolne rodniki tlenowe i wywołując depolaryzację błon i jej uszkodzenia. To prowadzi do naruszenia struktury bakterii i wycieku kwasów nukleinowych oraz białek. W ten sposób hamowany jest rozwój patogenów [Ren i in. 2019].

Innymi przykładami związków należących do stilbenów, o udokumentowanych właściwościach antybakteryjnych, są tetrastilbeny - kolofenol-A i -B, które działają wobec S. aureus [Shahidi i Yeo 2018].

\section{Flawonoidy}

Flawonoidy powszechnie występują w warzywach, owocach, orzechach, nasionach, łodygach i kwiatach roślin, herbacie, winie, propolisie i miodzie [Cushnie i Lamb 2005]. W roślinie najczęściej występują w formie aglikonów o charakterze hydrofobowym lub jako glikozydy (wówczas charakter związku zmienia się na bardziej hydrofilny). W glikozydach najczęściej występują glukoza, galaktoza, ramnoza, ksyloza i arabinoza [Makowska-Wąs i Janeczko 2004]. Rolą flawonoidów występujących w kwiatach jest zapewnienie im barwy przyciągającej owady zapylające. Natomiast tym znajdującym się w liściach przypisuje się funkcję ochronną przed grzybami chorobotwórczymi lub promieniowaniem UV-B. Dodatkowo poprzez działanie antyoksydacyjne ograniczają szkodliwość wolnych rodników powstających w trakcie fotosyntezy [Cushnie i Lamb 2005, Adaszyńska i Swarcewicz 2013b]. Inne funkcje flawonoidów $\mathrm{w}$ roślinach to udział w transferze energii, działaniu hormonów wzrostu, kontroli fotosyntezy i oddychania oraz determinacji płci. Są także częścią systemu ochronnego rośliny przed atakiem roślinożerców, gdyż nadają roślinom gorzki smak lub posiadają właściwości fotouczulające [Cushnie i Lamb 2005, Muth i Kachlicki 2009, Quinn i in. 2014].

Chociaż jest stosunkowo niewiele badań nad interakcją struktury flawonoidów i ich aktywnością przeciwbakteryjną, wyniki tych badań pozwoliły zidentyfikować wspólne cechy w budowie aktywnych związków. Antybakteryjny mechanizm działania oraz jego siła ściśle związane są z budową chemiczną oraz obecnością lub brakiem określonych grup funkcyjnych. Wykazano na przykład, że flawonoidy niezawierające grupy -OH w pierścieniu B (czyli cząsteczki mniej polarne) mają silniejsze działanie przeciwbakteryjne niż związki bez tej cechy w budowie [Cushnie i Lamb 2005, Adaszyńska i Swarcewicz 2013a, Skroza i in. 2019]. Naukowcy próbowali także ustalić, czy flawonoidy działają na bakterie statycznie czy bójczo. 
Na podstawie opublikowanych badań można wyciągnąć wniosek, że nie działają one bakteriobójczo, ale powodują tworzenie się agregatów bateryjnych, przez co zmniejsza się całkowita liczba kolonii bakteryjnych [Cushnie i Lamb 2005].

Jednym z mechanizmów działania przeciwdrobnoustrojowego flawonoidów jest hamowanie syntezy kwasów nukleinowych. Mori i in. w 1987 r., na podstawie wyników ze swoich badań z wykorzystaniem takich flawonoidów jak robinetyna, myricetyna i epigallokatechina, wyciągnęli wniosek, że pierścień B flawonoidów może wpływać na interkalację lub wiązania wodorowe łączące zasady azotowe w strukturze drugorzędowej kwasów nukleinowych, co może wyjaśniać hamujące działanie na syntezę DNA i RNA [Cushnie i Lamb 2005]. Inny wykryty mechanizm to hamowanie działania gyrazy DNA. Ohemeng i in. [1993] stwierdzili, że działanie inhibitorowe wobec tego enzymu wykazywały głównie flawonoidy, w których strukturze występowała hydroksylacja w pierścieniu B. Również Plaper $i$ in. [2003] doszli do wniosku, że przeciwbakteryjne działanie kwercetyny może być przynajmniej częściowo związane $z$ hamowaniem gyrazy DNA [Plaper i in. 2003].

Przykładem innego mechanizmu flawonoidów jest zaburzanie funkcji błony cytoplazmatycznej bakterii. Wykazano korelację pomiędzy przeciwbakteryjnym działaniem jednego z flawanonów (soforanoflawanonu $\mathrm{G}$ ) a obniżeniem płynności błony cytoplazmatycznej komórki bakteryjnej. Wyniki innych badań sugerują, że katechiny mogą wnikać przez podwójną warstwę lipidową błony i zaburzać jej funkcje barierowe. Związki z tej grupy słabiej działają na bakterie Gramdodatnie ze względu na różnice w budowie ściany komórkowej Gram-dodatnich i Gram-ujemnych bakterii. U Gram-ujemnych lipopolisacharyd ściany komórkowej stanowi bardziej skuteczną barierę i obserwowany efekt biologiczny jest mniejszy [Cushnie i Lamb 2005]. Oddziaływanie na błony komórkowe oraz ich niszczenie udowodnili także w swoich badaniach Stapleton i in. w 2004 r. [Cushnie i Lamb 2005]. Tagousop i in. [2018], badając przeciwdrobnoustrojowe działanie ekstraktów, zawierających glikozydy flawonoidowe z Graptophyluum grandulosum, wykazali, że uszkadzały one błonę cytoplazmatyczną bakterii i powodowały utratę wewnątrzkomórkowych składników [Tagousop i in. 2018].

Wykazano także, że flawonoidy mogą spowolnić metabolizm drobnoustrojów. Haraguchi i in. [1998], po przeprowadzeniu badań nad działaniem przeciwdrobnoustrojowycm likochalkonów A i C z korzeni rośliny Glycyrrhiza inflata, wysnuli hipotezę, że związki te mogą zakłócać metabolizm energetyczny podobnie jak antybiotyki hamujące oddychanie. Zaobserwowali oni, że badane ekstrakty w znacznym stopniu obniżyły zużycie tlenu przez komórki $M$. luteus i S. aureus, podczas gdy takie zjawisko nie wystąpiło w przypadku komórek bakterii E. coli, co było jednocześnie silnie skorelowane z działaniem przeciwbakteryjnym likochalkonów [Haraguchi i in. 1998].

\section{Terpenoidy}

Terpenoidy stanowią największą grupę biologicznie aktywnych substancji roślinnych. Należą do niej oligopolimery izopropenu. Funkcje tych związków 
w tkankach roślinnych związane są z adaptacją do warunków stresu abiotycznego oraz biotycznego (np. atak patogenów czy zwierząt roślinożernych) [Kabera i in. 2014]. Dodatkowo ze względu na wysoką lotność terpenoidów, rośliny mogą komunikować się poprzez nie z innymi organizmami, takimi jak sąsiednie rośliny, owady zapylające czy wrogowie roślinożerców [Maffei 2010]. Wiele z nich wykazuje właściwości przeciwdrobnoustrojowe i antywirusowe [Kabera i in. 2014].

\title{
Diterpeny
}

Związki należące do furanoditerpenów, wyizolowane z nasion Caesalpinia sappan, wykazywały antybakteryjne działanie wobec gatunku $S$. aureus, w tym szczepu opornego na metycylinę MRSA [Zhang i in. 2013]. Diterpeny o licznych właściwościach przeciwbakteryjnych są także głównymi składnikami aktywnymi roślin z rodzaju szałwia. Dang i in. [2018] wykazali antybakteryjną aktywność ekstraktów szałwii (Salvia pratii) wobec $S$. aureus, P. aeruginosa i A. baumannii.

\section{Karotenoidy}

Karotenoidy są to naturalne związki wytwarzane przez rośliny, niektóre bakterie i grzyby. Aby miały one kolor żółty, pomarańczowy czy czerwony w swojej strukturze muszą zawierać przynajmniej 7 sprzężonych wiązań podwójnych, w innych przypadkach są bezbarwne [Muszyńska i in. 2016]. Ekstrakty z papryki, zawierające kapsantynę i kapsorubinę (główne karotenoidy odpowiedzialne za barwę papryki), wykazywały działanie antybakteryjne, skuteczniejsze na bakterie Gram-dodatnie (S. aureus), chociaż Gram-ujemne (E. coli) też były w pewnym stopniu na nie wrażliwe. Obecność grup alkoholowych (-OH) w strukturze badanego pigmentu zwiększa aktywność przeciwdrobnoustrojową, ze względu na zmianę natury białka komórkowego i wzrost przepuszczalności błon komórkowych [Hussein 2016]. Ernawita i in. [2016] badali aktywność ekstraktów karotenoidowych z różnych owoców cytrusowych i wykazali ich działanie bakteriostatyczne wobec bakterii S. aureus (większe) i K. pneumoniae (mniejsze). Aktywność ekstraktów uzyskanych z miąższu owoców była większa niż tych ze skórki [Ernawita i in. 2016].

\begin{abstract}
Alkaloidy
Alkaloidy są zasadowymi związkami organicznymi o bardzo zróżnicowanej strukturze. Ich cechą wspólną jest obecność przynajmniej jednego atomu azotu, choć w niektórych związkach występuje nawet pięć takich atomów [Cushnie i in. 2014, Barbieri i in. 2017]. Główne funkcje alkaloidów w roślinach to odstraszanie zwierząt roślinożernych, ochrona przed toksycznymi produktami ubocznymi procesu fotosyntezy poprzez zdolność do wygaszania tlenu singletowego oraz ochrona przed infekcją (fitoantycypiny i fitoaleksyny) [González-Lamothe i in. 2009, Mithöfer i Boland 2012, Cushnie i in. 2014].

Alkaloidy wykazują działanie antybakteryjne oraz antywirusowe. Przykładem może być sanguinarina, izolowana z kłączy Sanguinaria canadensis. Wywiera ona działanie przeciwdrobnoustrojowe poprzez zakłócenia w tworzeniu głównego
\end{abstract}


białka zaangażowanego w proces podziału komórkowego (FtsZ) oraz hamowanie cytokinazy [Beuria i in. 2005, Croaker i in. 2016]. Cushnie i in. [2014] opisali kilka mechanizmów działania antybakteryjnego alkaloidów. Pergularinina i tyloforynidyna hamują syntezę kwasu nukleinowego poprzez blokowanie enzymu reduktazy dihydrofolianowej. Bardziej zróżnicowane działanie wykazują sanguinarina i berberyna, które wiążą się z FtsZ, hamują tworzenie pierścienia Z wokół bieguna komórki lub indukują wydłużenie komórek bez wpływu na replikację DNA, segregację nukleotydów czy strukturę błony komórkowej [Cushnie i in. 2014]. Avci i in. [2018] badali aktywność przeciwbakteryjną trzech roślinnych alkaloidów - boldyny, bulgokapniny i roemeryny - wobec komórek $B$. subtilis. Jedynie roemeryna wykazywała działanie antybakteryjne poprzez gromadzenie się w ścianie komórkowej bakterii i wywołanie stresu oksydacyjnego w wyniku tworzenia reaktywnych form tlenu, co deregulowało różne szlaki metaboliczne, w tym pobieranie jonów żelaza [Avci i in. 2018].

\section{Związki zawierające siarkę}

Związki organiczne zawierające siarkę, takie jak allicyna, ajoen czy izotiocyjaniany, wykazują działanie przeciwbakteryjne zarówno wobec bakterii Gram-dodatnich, jak i Gram-ujemnych.

Związki siarki stosunkowo rzadko występują wśród roślin wyższych. Rośliny z rodziny Alliaceae (czosnkowate) wytwarzają allilowe pochodne cysteiny, do których należy alliina. Natomiast u przedstawicieli należących zarówno do rzędu Brassicales (kapustowce), jak i do rodzin Pittosporaceae i Phytolaccaceae (szarłatowate), można spotkać glukozynolany. St-Gelais i in. [2015] wyizolowali z korzeni, kory i drewna drzewa Dira paluris kolejną grupę metabolitów wtórnych zawierających siarkę i nazwali ją dichromonami. Jest to pierwsza grupa takich związków w rodzinie Thymelaeaceae (wawrzynkowate).

Glukozynolany występują w takich warzywach jak: kapusta, brokuł, rukiew wodna, chrzan, brukselka i kalarepa. Nienaruszone glukozynolany nie mają właściwości przeciwdrobnoustrojowych, zyskują je dopiero po hydrolizie pod wpływem mirozynazy ( $\beta$-tioglukozydaza), przekształcone do izotiocyjanianów, nitryli, epitionitryli czy tiocyjanianów. Udowodniona jest przecidrobnoustrojowa aktywność tych związków wobec licznych gatunków, m.in. E. coli, C. albicans, B. subtilis, C. jejuni, H. pylori i V. parahaemoliticus [Borges i in. 2015]. Borges i in. [2015] na podstawie badań wykazali aktywność przeciwbakteryjną dwóch izotiocyjanianów - allylizotiocyjanianu i fenyletylizotiocyanianu wobec gatunków E. coli, P. aeruginosa, S. aureus i L. monocytogenes. Oceniali także wybrane wyróżniki fizjologiczne komórek bakteryjnych. Badane związki powodowały zmianę ładunku powierzchniowego błony komórkowej, co skutkowało przerwaniem jej integralności i wyciekiem cytoplazmy poza komórkę [Borges i in. 2015]. Hinds i in. [2017] badali aktywność przeciwbakteryjną pięciu glukozynolanów wyizolowanych z brokułów wobec kilku gatunków bakterii. Jedynie synigryna przejawiała silną aktywność antybakteryjną, w dodatku tylko względem bakterii 
Gram-dodatnich (S. aureus, MRSA i B. cereus), natomiast żaden z glukozynolanów nie wykazał aktywności wobec bakterii Gram-ujemnych [Hinds i in. 2017]. Obserwowano także zahamowanie wzrostu grzybów z gatunków G. graminis, $L$. maculans, $R$. solani, F. graminearum, B. sorokiniana i P. irregulare w obecności izotiocyjanianów [Smolinska i in. 2003].

Allicyna (związek powstający $\mathrm{z}$ alliiny $\mathrm{w}$ wyniku hydrolizy enzymatycznej w obecności alliinazy) jest to substancja występująca m.in. w czosnku. Ekstrakt czosnku $0,5 \%$ ma właściwości hamujące wzrost drobnoustrojów chorobotwórczych [Meyer i in. 2002].

Dichromony wykazywały działanie przeciwdrobnoustrojowe wobec bakterii $S$. aureus, natomiast nie działały na Gram-ujemne komórki E. coli i grzyby C. albicans [St-Gelais i in. 2015].

\section{Kumaryny}

Kumaryny są pochodnymi benzo- $\alpha$-pironu o budowie dwupierścieniowej [Adaszyńska i Swarcewicz 2013b]. Najczęściej spotykane są w nasionach (kawa, orzechy), owocach (głównie cytrusowych), warzywach (pomidory, brokuły, papryka) i korzeniach roślin [Bielawska i in. 2014]. Zazwyczaj w roślinie występują w formie glikozydów lub wchodzą w skład olejków eterycznych. Wykazują znaczące działanie przeciwdrobnoustrojowe. Jedna z najważniejszych izokumaryn marchwi, czyli 6-metylomeleina wykazała toksyczne działanie wobec grzybów i bakterii, przy czym Alternaria alternata była najbardziej na nią wrażliwa [De Girolamo i in. 2004]. Dentatyna i nordentatyna, wyizolowane z Clausena excavata, wykazywały działanie antybakteryjne wobec mykobakterii. W innych badanich udowodniono aktywność przeciwbakteryjną w stosunku do $S$. aureus, $P$. vulgaris, $P$. aeruginosa, $P$. mirabilis oraz E. cloacae grandiwtiny wyizolowanej z Ferulaga campestris [Adaszyńska i Swarcewicz 2013a, 2013b]. Długołańcuchowe alkilowe pochodne kumaryny (ammoresinol i ostrutyna) działały antybakteryjnie wobec B. megaterium, M. luteus i S. aureus. Natomiast imperatoryna z Angelica dahurica i Angelica archangelica wykazywała aktywność antybakteryjną wobec $S$. dysenteriae. Pirokumaryny wyizolowane z korzeni Ferulago campestris miały właściwości przeciwbakteryjne wobec $S$. aureus, S. Typhi, E. cloacae, E. aerogenes oraz H. pylori [Bielawska i in. 2014]. W badaniach przeprowadzonych przez Tamene i Endale [2019] wykazano znaczne zahamowanie wzrostu bakterii S. aureus i $B$. subtilis przez pochodne haptafiliny i imperatoryny, wyekstrahowane z korzeni Clausena anisata.

Kumaryny wykazują również działanie antywirusowe. Dentyna i nordentatyna (piranokumaryny), izolowane z Clausena excavata, hamowały działanie wirusa HIV-1. Natomiast kalanolid A (dipiranokumaryna) i B (piranokumaryna) uzyskane z Calophyllum lanigerum całkowicie blokują replikację tego wirusa. Znaczną aktywność anty-HIV wykazywały również inne piranokumaryny (ang. pseudocordatolide C i calanolide F), uzyskane z ekstraktów z Calophyllum lanigerum i Calophyllum teysmannii [Bielawska i in. 2014]. 


\section{Fitosterole}

Fitosterole, czyli sterole roślinne, spotykane są w jadalnych i leczniczych roślinach, w tym w nasionach i ich olejach. Do najbardziej aktywnych związków z tej grupy należą: kampesterol, stigmasterol i $\beta$-sitosterol [Toiu i in. 2019]. Związki te pod względem budowy i funkcji są roślinnym odpowiednikiem cholesterolu. Wchodzą one w skład błon komórkowych roślin, obniżając płynność, głównie powierzchniowej warstwy [Kopeć $\mathrm{i}$ in. 2011]. Wykazano pozytywny związek pomiędzy poziomem steroli roślinnych w olejach z orzechów laskowych (przede wszystkim $\beta$-sitosterolu, kampesterolu, avanasterolu i stigmasterolu) a aktywnością przeciwdrobnoustrojową [Veličkovska $\mathrm{i}$ in. 2018]. W badaniach nad ekstraktem z kory Neocarya macrophylla wykazano działanie przeciwdrobnoustrojowe stigmasterolu wobec S. pyogenes, B. subtilis, B. cereus, E. coli i C. albicans [Yusuf i in. 2018].

\section{Glikozydy}

Glikozydy to pochodne węglowodanów i związków niecukrowych: fenolowych, alkoholi lub zawierających siarkę. Wiele roślin magazynuje związki chemiczne w formie nieaktywnych glikozydów, które mogą być aktywowane w odpowiednim momencie przez enzymy hydrolityczne [Kabera i in. 2014].

Do glikozydów o bardziej złożonej strukturze należą saponiny. Są to glikozylowane antycypiny, spotykane w wielu gatunkach roślin i, w zależności od struktury ich aglikonów, mogą należeć do jednej z trzech głównych grup: triterpenoidów, steroidów i glikoalkaloidów steroidowych. Ze względu na ich aktywność przeciwdrobnoustrojową uważa się, że naturalną rolą tych cząsteczek w roślinie jest wspomaganie ochrony przeciwko potencjalnym patogenom. Najlepiej poznane są potencjalne mechanizmy obronne avenacyny i $\alpha$-tomatyny. Avenacyny są saponinami z korzeni owsa. Aktywność przeciwgrzybiczna tych związków jest związana $\mathrm{z}$ ich zdolnością do tworzenia kompleksów ze sterolami obecnymi w błonie grzybów, co prowadzi do powstawania w niej porów, a tym samym zaburzona jest ciągłość błony.

Natomiast $\alpha$-tomatyna jest główną saponiną w pomidorach. Jest ona gromadzona w zdrowych roślinach w biologicznie aktywnej formie. Zależność pomiędzy nagromadzeniem się tego związku w roślinie a jej odpornością na choroby nie była łatwa do udowodnienia. Spowodowane to było tym, że prowadzono badania z wykorzystaniem grzybów, które wytwarzały enzym rozkładający $\alpha$-tomatynę, a tym samym wykazywały na nią odporność. Kiedy zastosowano w badaniach zmutowane szczepy, pozbawione wspomnianego enzymu, nie były one w stanie porażać rośliny [Bouarab i in. 2002]. W innych badaniach wykazano, że produkty rozpadu $\alpha$-tomatyny są w stanie stłumić reakcję obronną organizmu. W związku z tym brak odporności rośliny na dany patogen nie może być wiązany jedynie ze zniknięciem przeciwdrobnoustrojowego związku, ale także ze zdolnością produktów jego rozkładu do obniżenia odpowiedzi obronnej organizmu [González-Lamothe i in. 2009]. 


\section{Wpływ ekstraktów roślinnych na chorobotwórcze grzyby drożdżoidalne}

Grzyby drożdżoidalne z rodzaju Candida uważane są za drobnoustroje komensalne, które mają również zdolność powodowania chorób, tzw. kandydoz, u ludzi o obniżonej odporności immunologicznej. Szacuje się, że infekcje powodowane przez Candida mogą powodować ok. 71\% przypadków zachorowań i 5\% przypadków śmiertelnych w środowisku szpitalnym. Przyczyna tego stanu leży w oporności grzybów drożdżoidalnych na dostępne środki farmaceutyczne oraz zdolności do tworzenia biofilmu na materiałach i wyposażeniu medycznym [Giongo i in. 2016].

Gatunkiem o najwyższym stopniu patogenności jest $C$. albicans, który charakteryzuje się dualnym cyklem rozwoju (komensalnym i chorobotwórczym) w organizmie człowieka. Candida albicans jest grzybem polimorficznym, u którego zmiany morfogenetyczne są częścią mechanizmu patogenezy w komórkach gospodarza. Forma drożdżowa jest związana z kolonizacją bezobjawową, transmisją i rozprzestrzenianiem szczególnie z krwią, natomiast forma mycelialna (przyjmuje postać nitkowatych strzępek) związana jest z adhezją i inwazją śluzówki charakterystyczną dla objawów chorobowych oraz produkcją czynników powodujących lizę makrofagów [Cauchie i in. 2017]. Gatunek ten jest główną przyczyną kandydoz pochwy i sromu (VVC - vulvovaginal candidiasis) u kobiet na całym świecie, a dokładne mechanizmy patogenezy tego grzyba zostały zaprezentowane w publikacji Pytki i in. [2019]. Cechy chorobotwórcze, m.in. zdolność do tworzenia biofilmu, wykryto również u innych grzybów drożdżoidalnych z rodzaju Candida: C. tropicalis, C. guilliermondii, C. krusei, C. parapsilosis, C. glabrata, C. dubliniensis i $C$. kefyr, które należą do naturalnej mikrobioty człowieka [Giongo i in. 2016]. Obserwuje się wzrost infekcji powodowanych przez grzyby drożdżoidalne inne niż albicans, ponieważ wykazują one dużą oporność na powszechnie stosowane czynniki antygrzybowe, np. flukonazol [Mandras i in. 2016, Bassyouni i in. 2019].

Odpowiedzią na ten problem są badania nad właściwościami antygrzybowymi ekstraktów pochodzenia roślinnego, które mogłyby uzupełnić rynek leków przeciw 
infekcjom wywoływanym drożdżakami. Jednocześnie z badaniami aktywności przeciwdrobnoustrojowej substancji roślinnych trwają prace nad tworzeniem różnych formuł preparatów o skutecznym działaniu, np. inkorporacji w nanostruktury [Giongo i in. 2015].

Li i in. [2016] oznaczyli aktywność przeciwdrobnoustrojową, kinetykę oraz mechanizm molekularny działania olejku czosnkowego na C. albicans. MIC oznaczono metodą płytkową w podłożu uzupełnionym różnymi stężeniami olejku i wyniósł on $0,35 \mu \mathrm{g} \cdot \mathrm{cm}^{-3}$. Badania kinetyki wskazały, że jego efekt bójczy na grzyby drożdżoidalne zależał od czasu działania oraz dawki. Obserwacje w mikroskopie elektronowym wskazały, że olejek może penetrować zarówno błonę komórkową, jak i błony organelli, powodując ich destrukcję i w konsekwencji śmierć komórki. Natomiast analiza sekwencji RNA wykazała ekspresję różnych, krytycznych genów, m.in. związanych z reakcjami utleniania i redukcji w komórce, patogenezą i odpowiedzią komórkową na związki toksyczne i głodzenie [Li i in. 2016].

W badaniach Giongo i in. [2016] grzyby drożdżoidalne C. albicans, C. tropicalis, C. glabrata i C. krusei były poddane działaniu olejku z geranium Pelargonium graveolens, który znany jest z działania terapeutycznego w różnych schorzeniach, np. biegunce, chorobach skóry, wrzodach żołądka i innych, dzięki takim składnikom jak citronellol i geraniol [Shawl i in. 2006]. Badanie aktywności antygrzybowej metodą mikrorozcieńczeń wykazało, że grzyby drożdżoidalne C. albicans, C. tropicalis i C. krusei były wrażliwe na olejek (MIC wynosił 1,82-3,64 $\mu \mathrm{g} \cdot \mathrm{cm}^{-3}$ ), zaś $C$. glabrata były dużo bardziej oporne $\left(\mathrm{MIC}=14,6 \mu \mathrm{g} \cdot \mathrm{cm}^{-3}\right)$. Olejek w postaci nanoemulsji działał słabiej. Obie formy olejku hamowały w różnym stopniu tworzenie biofilmu przez badane grzyby drożdżoidalne na płytkach polietylenowych i cewnikach poliuretanowych, co daje szanse na wykorzystanie ich w celach medycznych [Giongo i in. 2016]. Z kolei Mandras i in. [2016] wykazali wrażliwość 46 izolatów klinicznych grzybów drożdżoidalnych C. albicans, C. tropicalis i C. glabrata na olejki eteryczne z tymianku (Thymus vulgaris), kopru włoskiego (Foeniculum vulgarae), goździka (Eugenia caryophyllata), sosny (Pinus silvestris), szałwii (Salvia officinalis), melisy (Melissa officinalis) i lawendy (Lavandula vera). Badacze potwierdzili działanie wszystkich olejków, a najbardziej skuteczne okazały się olejki tymiankowy i sosnowy, które najmocniej działały na C. albicans - MIC90 (zahamowanie 90\% komórek) wynosił odpowiednio $0,125 \%$ i $0,06 \% \mathrm{v} \cdot \mathrm{v}^{-1}$. W olejkach tych dominowały odpowiednio tymol i $\alpha$-pinen [Mandras i in. 2016]. W badaniach Piekut [2017] nad wpływem ekstraktów roślin przyprawowych (imbiru, kopru, lubczyku, tymianku, kwiatu nagietka) wykazano skuteczne działanie hamujące w $90 \%$ rozwój C. albicans przez dodatek do hodowli mikroorganizmu ekstraktu etanolowego z lubczyku, bogatego w związki fenolowe [Piekut 2017]. Khan [2017] sprawdził działanie ekstraktu wodnego i metanolowego nasion kopru włoskiego metodą krążkowo-dyfuzyjną na potencjalnie chorobotwórcze grzyby drożdżoidalne z rodzaju Candida i stwierdził efekt hamowania wzrostu C. albicans, C. glabrata i C. tropicalis. Bassyouni i in. [2019] badali 
Tabela 13. Przykłady substancji i związków roślinnych działających na chorobotwórcze grzyby drożdżoidalne

\begin{tabular}{|c|c|c|c|}
\hline $\begin{array}{l}\text { Substancja } \\
\text { aktywna }\end{array}$ & Grzyby drożdżoidalne & \begin{tabular}{|c|} 
Efekt \\
przeciwdrobnoustrojowy
\end{tabular} & Źródło \\
\hline $\begin{array}{l}\text { Olejek } \\
\text { czosnkowy }\end{array}$ & C. albicans ATCC 10231 & $\mathrm{MIC}=0,35 \mu \mathrm{g} \cdot \mathrm{cm}^{-3}$ & Li i in. 2016 \\
\hline $\begin{array}{l}\text { Olejek } \\
\text { geraniowy } \\
\text { z Pelargonium } \\
\text { graveolens }\end{array}$ & $\begin{array}{l}\text { C. albicans ATCC } 14053 \text {, } \\
\text { C. tropicalis ATCC } 66029 \text {, } \\
\text { C. glabrata ATCC } 66032 \text {, } \\
\text { C. krusei ATCC } 6258\end{array}$ & $\begin{array}{l}\text { MIC }=1,82 \mu \mathrm{g} \cdot \mathrm{cm}^{-3} \\
\text { MIC }=1,82 \mu \mathrm{g} \cdot \mathrm{cm}^{-3} \\
\text { MIC }=14,6 \mu \mathrm{g} \cdot \mathrm{cm}^{-3} \\
\text { MIC }=3,64 \mu \mathrm{g} \cdot \mathrm{cm}^{-3}\end{array}$ & $\begin{array}{l}\text { Giongo i in. } \\
2016\end{array}$ \\
\hline $\begin{array}{l}\text { Olejek } \\
\text { eteryczny } \\
\text { z tymianku }\end{array}$ & $\begin{array}{l}\text { C. albicans, } \\
\text { C. glabrata, } \\
\text { C. tropicalis }\end{array}$ & $\begin{array}{l}\text { MIC90 }=0,125 \% \mathrm{v} \cdot \mathrm{w}^{-1} \\
\text { MIC90 }=0,125 \% \mathrm{v} \cdot \mathrm{w}^{-1} \\
\text { MIC90 }=0,250 \% \mathrm{v} \cdot \mathrm{w}^{-1}\end{array}$ & $\begin{array}{l}\text { Mandras } i \text { in. } \\
2016\end{array}$ \\
\hline $\begin{array}{l}\text { Olejek } \\
\text { eteryczny } \\
\text { z sosny }\end{array}$ & $\begin{array}{l}\text { C. albicans, } \\
\text { C. glabrata, } \\
\text { C. tropicalis }\end{array}$ & $\begin{array}{l}\text { MIC90 }=0,06 \% \mathrm{v} \cdot \mathrm{w}^{-1} \\
\text { MIC90 }=0,25 \% \mathrm{v} \cdot \mathrm{w}^{-1} \\
\text { MIC90 }=0,50 \% \mathrm{v} \cdot \mathrm{w}^{-1}\end{array}$ & $\begin{array}{l}\text { Mandras i in. } \\
2016\end{array}$ \\
\hline $\begin{array}{l}\text { Ekstrakt } \\
\text { etanolowy } \\
\text { z lubczyku }\end{array}$ & C. albicans PKM PAN & $\begin{array}{l}\text { hamowanie wzrostu } \\
\text { o } 90 \% \mathrm{v} \cdot \mathrm{w}^{-1}\end{array}$ & Piekut 2017 \\
\hline $\begin{array}{l}\text { Ekstrakt wodny } \\
\text { i metanolowy } \\
\text { z kopru } \\
\text { włoskiego }\end{array}$ & $\begin{array}{l}\text { C. albicans, } \\
\text { C. tropicalis, } \\
\text { C. glabrata }\end{array}$ & $\begin{array}{l}\text { obecność stref } \\
\text { zahamowania wzrostu }\end{array}$ & Khan 2017 \\
\hline $\begin{array}{l}\text { Olejek z kopru } \\
\text { włoskiego }\end{array}$ & $\begin{array}{l}\text { C. albicans ATCC } 10231 \text {, } \\
\text { izolaty C. albicans od kobiet } \\
\text { chorych na VVC }\end{array}$ & $\begin{array}{l}\text { MIC }=0,78 \% \mathrm{v} \cdot \mathrm{w}^{-1} \\
\mathrm{MIC}=0,78-6,25 \% \mathrm{v} \cdot \mathrm{w}^{-1}\end{array}$ & $\begin{array}{l}\text { Bassyouni i in. } \\
2019\end{array}$ \\
\hline $\begin{array}{l}\text { Olejek } \\
\text { eteryczny } \\
\text { z Clausena } \\
\text { lansium }\end{array}$ & $\begin{array}{l}\text { C. albicans ATCC } 10231 \text {, } \\
\text { C. tropicalis CMCCF c2f, } \\
\text { C. glabrata CMCCF c6e, } \\
\text { C. krusei ATCC } 6258, \\
\text { C. parapsilosis ATCC } 22019 \text {, } \\
\text { izolaty kliniczne C. albicans }\end{array}$ & $\begin{array}{l}\text { strefy inhibicji: } \\
8,0-13,5 \mathrm{~mm} \\
6,5-15,5 \mathrm{~mm} \\
20,0-23,1 \mathrm{~mm} \\
11,2-19,3 \mathrm{~mm} \\
7,9-12,1 \mathrm{~mm} \\
8,1-15,3 \mathrm{~mm} \\
\end{array}$ & He i in. 2019 \\
\hline $\begin{array}{l}\text { Ekstrakty } \\
\text { z tymianku } \\
\text { surowe } \\
\text { i w nośnikach }\end{array}$ & C. albicans ATCC 10231 & $\begin{array}{l}\text { strefa inhibicji } \\
0,0-12,0 \mathrm{~mm} \\
\text { MIC } 0,25->2,5 \mathrm{mg} \cdot \mathrm{cm}^{-3}\end{array}$ & Pinna i in. 2019 \\
\hline
\end{tabular}

działanie olejków: z rumianu rzymskiego (Anthemis nobile), z kopru włoskiego (Foeniculum vulgare), jojoba (Simmondsia chinensis), czarnuszki siewnej (Nigella sativa), kozieradki (Trigonella foenum-graecum), czapetki pachnącej (Syzygium aromaticum) i imbiru (Zingiber officinale) na izolaty C. albicans pozyskane od 
kobiet chorych na kandydozę oraz na C. albicans ATCC 10231 i stwierdzili najwyższą aktywność antygrzybową olejku z kopru włoskiego. MIC tego olejku dla wszystkich badanych szczepów mieścił się w zakresie 0,78-6,25\%. Preparat roślinny działał również biobójczo na komórki tworzące biofilm, gdzie MIC50 wynosił 3,12\%, a MIC $90-6,25 \%$ [Bassyouni i in. 2019]. He i in. [2019] sprawdzili działanie olejku eterycznego z liści lub owocni Clausena lansium na grzyby drożdżoidalne C. albicans, C. parapsilosis, C. krusei, C. tropicalis, C. glabrata metodą krążkowo-dyfuzyjną i otrzymali strefy zahamowania wzrostu wszystkich szczepów w zakresie 6,5-23,1 mm. Najbardziej wrażliwa okazała się C. glabrata, dając strefy inhibicji powyżej $20 \mathrm{~mm}$. Z kolei wyższą aktywność grzybobójczą wykazały olejki z owocni, bogate w $\beta$-fellandren i $\beta$-seskwifellandren [He i in. 2019]. Pinna i in. [2019] badali wpływ surowych ekstraktów z tymianku i cytryny oraz ekstraktów pakowanych w nanocząsteczki, np. liposomy lub glycerosomy, na C. albicans. Wykazali skuteczne działanie przeciwdrobnoustrojowe ekstraktu z tymianku, w metodzie krążkowo-dyfuzyjnej strefa inhibicji wynosiła $12 \mathrm{~mm}$ dla surowego ekstraktu i ok. $12 \mathrm{~mm}$ dla glycerosomów. MIC surowego ekstraktu wynosił $0,25 \mathrm{mg} \cdot \mathrm{cm}^{-3}$, ale nanocząsteczki działały znacznie słabiej, dając MIC $>2,5 \mathrm{mg} \cdot \mathrm{cm}^{-3}$. W teście time-kill grzyby drożdżoidalne po $3 \mathrm{~h}$ ekspozycji na surowy ekstrakt tymiankowy wykazały 30 procentowy spadek żywotności. Badacze nie wykazali działania ekstraktu z cytryny na C. albicans. Zestawienie badań nad działaniem substancji roślinnych na grzyby drożdżoidalne przedstawia tabela 13 . 


\section{Wpływ ekstraktów roślinnych na chorobotwórcze grzyby pleśniowe}

Grzyby pleśniowe, znane przede wszystkim jako środowiskowe saprofity rozkładające szczątki organiczne, mogą być przyczyną poważnych schorzeń u ludzi. Grzyby z rodzaju Aspergillus występują na całej kuli ziemskiej i spośród ponad 185 gatunków $20 \mathrm{z}$ nich są to gatunki chorobotwórcze. Wśród nich A. flavus powoduje bezpośrednie infekcje i choroby systemiczne u ludzi i razem z A. fumigatus, A. terreus, A. nidulans, A. clavatus i A. niger są przyczyną inwazyjnych aspergiloz, które występują rzadko u osób z prawidłową odpornością, ale dają wysoki wskaźnik zachorowalności i śmiertelności u pacjentów z obniżoną odpornością [Wierzbicka 2001, Tian i in. 2012]. Wykazano, że konidia A. fumigatus łatwo docierają do płuc wraz z powietrzem i u osób z upośledzonym układem immunologicznym nie są właściwie neutralizowane, zaczynają kiełkować, a młode strzępki wnikają w miąższ płucny, powodując uszkodzenie tkanki i są przyczyną inwazyjnego lub przewlekłego zakażenia dróg oddechowych. Objawy chronicznej aspergilozy płuc mogą prowadzić do systemicznego zakażenia i pogorszenia funkcjonowania płuc [Zacharias i Sheppard 2019]. Postać przewlekła, martwicza aspergilozy zwykle z czasem prowadzi do obumierania tkanki płucnej. Z kolei alergiczna aspergiloza oskrzelowo-płucna spowodowana jest miejscową reakcją immunologiczną na kolonizację drzewa oskrzelowego przez grzyby [Wierzbicka 2001].

Innym ważnym problemem są schorzenia różnych narządów człowieka pojawiające się po spożyciu skażonych produktów żywnościowych grzybami pleśniowymi zdolnymi do syntezy i wydzielania mikotoksyn. Duża grupa grzybów wytwarza w sumie ponad 400 mikotoksyn [Libudzisz i in. 2008]. Aspergillus flavus jest jednym z głównych grzybów wytwarzających aflatoksyny - powszechnie występujące i niebezpieczne metabolity wtórne o silnym działaniu hepatotoksycznym. Około 4,5 miliarda ludzi narażonych jest na kontakt $\mathrm{z}$ tą mikotoksyną w ilościach niekontrolowanych, a aflatoksykoza zajmuje szóste miejsce wśród 10 najważniejszych zagrożeń dla zdrowia [Williams i in. 2004]. Wykazano, że aflatoksyny mają też 
działanie rakotwórcze, teratogenne, immunosupresyjne, a największe ryzyko stanowi aflatoksyna $\mathrm{B}_{1}$ umieszczona $\mathrm{w}$ grupie pierwszej kancerogenów ludzkich [Bluma i Etcheverry 2008]. Do innych, groźnych mikotoksyn należą m.in. fumonizyny o działaniu kancerogennym, uszkadzające nerki ochratoksyny, a także trichoteceny wywołujące toksyczną aleukemię żywieniową [Dec i in. 2017]. Ochratoksyna A wytwarzana jest głównie przez grzyby z gatunków: $A$. ochraceus, $A$. carbonarius, A. westerdijkiae, A. niger, $P$. nordicum i $P$. verrucosum rozwijających się na ziarnach zbóż, kawy, w napojach, winogronach i winach. Ochratoksyna A oprócz działania nefrotoksycznego jest teratogenna, embriotoksyczna, genotoksyczna, immunosupresyjna i immunotoksyczna z natury. Europejska Agencja Badań nad Rakiem sklasyfikowała ją jako potencjalnie kancerogenną (grupa 2A), a dopuszczalna jej ilość wynosi $5 \mu \mathrm{g} \cdot \mathrm{kg}^{-1} \mathrm{w}$ ziarnach zbóż [Hua i in. 2014]. Inne mikotoksyny o potencjalnym działaniu rakotwórczym to sterigmatocystyna, aflatoksyna $\mathrm{M}_{1}$, gryzeofulwina, fumonizyna $\mathrm{B}_{1}$, wytwarzane przez grzyby $A$. versicolor, A. nidulans, A. parasiticus, A. nomius, $P$. giseofulvum, F. moniliforme, $F$. verticillioides, F. poliferatum, również umieszczone są w grupie 2A [Libudzisz i in. 2008]. $\mathrm{Z}$ uwagi na środowisko wytwarzania mikotoksyn jakim jest żywność, istnieje pilna potrzeba poszukiwania alternatywnych do substancji chemicznych metod zapobiegających rozwojowi grzybów w surowcach i produktach spożywczych. Takim rozwiązaniem są ekstrakty roślinne lub ich składniki o silnym działaniu przeciwdrobnoustrojowym, które mogą stanowić naturalne konserwanty żywości.

\section{Przykłady działania ekstraktów roślinnych i olejków eterycznych na grzyby chorobotwórcze i toksynotwórcze}

Tian $\mathrm{i}$ in. [2011, 2012] badali wpływ olejku z kopru ogrodowego, zawierającego karwon, limonen i apiol na A. flavus i stwierdzili pozytywny wpływ na hamowanie grzyba z wartością MIC na poziomie $2 \mu \mathrm{l} \cdot \mathrm{cm}^{-3}$. Następnie wykazali metodą cytometrii przepływowej, że wraz ze wzrostem stężeń olejku dodawanego do hodowli w zakresie $0,25-2 \mu \mathrm{l} \cdot \mathrm{cm}^{-3}$ liczba uszkodzonych komórek grzyba sukcesywnie zwiększała się, jednocześnie zawartość ergosterolu w błonach komórkowych malała, osiągając przy dodatku $1 \mu \mathrm{l} \cdot \mathrm{cm}^{-3}$ olejku obniżenie zawartości o blisko 80\%. Zmniejszał się również mitochondrialny potencjał błonowy oraz aktywność mitochondrialnej ATP-azy i dehydrogenazy wraz ze wzrostem stężeń olejku koprowego. Autorzy wykazali również, że wzrost reaktywnych form tlenu wpływa krytycznie na przeżywalność komórek grzyba A. flavus [Tian i in. 2012].

W badaniach Dec i in. [2017] chorobotwórcze grzyby z rodzaju Aspergillus: A. flavus, A. fumigatus, A. ochraceus, A. parasiticus, A. niger i A. versicolor poddano działaniu metanolowych ekstraktów z różnych organów następujących roślin: melisy (Melisa officinalis L.), lubczyku ogrodowego (Levisticum officinale L.), rozmarynu lekarskiego (Rosmarinus officinalis L.), majeranku (Organum majorana L.), bylicy draganka (Artemisia dracunculus L.), szałwii lekarskiej (Salvia officinalis L.), imbiru (Zingiber officinale), leszczyny pospolitej (Corrylus avellana L.), pieprzu czarnego (Piper nigrum L.) i papryki (Capsicum L.). Dla większości 
ekstraktów MIC wyniósł $50 \mathrm{mg} \cdot \mathrm{cm}^{-3}$, za wyjątkiem szałwii $\left(250 \mathrm{mg} \cdot \mathrm{cm}^{-3}\right)$ oraz imbiru i leszczyny $\left(100 \mathrm{mg} \cdot \mathrm{cm}^{-3}\right)$. W metodzie studzienkowej wykazano skuteczne działanie ekstraktów z pieprzu i papryki wobec wszystkich gatunków, za wyjątkiem $A$. fumigatus. Ten gatunek był natomiast skutecznie hamowany przez działanie ekstraktów z lubczyku, rozmarynu i estragonu [Dec i in. 2017]. Aspergillus flavus i A. niger poddano również działaniu ekstraktów metanolowych i wodnych $\mathrm{z}$ maku kolczastego (Argemone mexicana L.), rośliny stosowanej w niektórych krajach do leczenia infekcji zębów lub chorób skórnych, brodawek, opryszczki, a nawet żółtaczki. Wykazano wysoką skuteczność obu rodzajów ekstraktów, szczególnie tych otrzymanych z łodyg, która była wyższa 1,5-1,8 razy od amfoterycyny B [More i Karat 2016].

Bluma i Etcheverry [2008] przetestowali 41 wodnych i etanolowych ekstraktów oraz 22 różne olejki eteryczne względem szczepów grzybów Aspergillus sekcji Flavi metodą in vitro i stwierdzili potencjał antygrzybowy olejków z boldo (Peunus boldus Mol), poleo (Lippia turbinate var. integrifolia), goździków (Syzygium aromaticum L.), anyżu (Pimpinella anisum L.) i tymianku górskiego (Thymus vulgaris), które wpływały na fazę lag i szybkość wzrostu grzybów w ziarnie kukurydzy oraz na hamowanie akumulacji aflatoksyny $\mathrm{B}_{1}$, osiągając wartość maksymalną przy stężeniu olejków 2-3 $\mathrm{mg} \cdot \mathrm{g}^{-1}$ [Bluma i Etcheverry 2008]. Okazało się, że olejki te mogły oddziaływać hamująco na wzrost $A$. niger i $A$. carbonarius w pożywce na bazie orzeszków ziemnych. Najbardziej skuteczny był olejek z boldo w stężeniu 1500 $\mu 1 \cdot 1^{-1}$ i $2000 \mu 1 \cdot 1^{-1}$, podawany odpowiednio drogą kontaktową i lotną. Nieco słabiej działały olejki z poleo i goździkowy. Autorzy dowiedli, że wywierały one wpływ hamujący na szlak syntezy ochratoksyny A [Passone i in. 2012].

Również olejki eteryczne z gwiazdnicy (Ageratum conyzoides) i oregano (Origanum vulgare), zawierające jako główne składniki odpowiednio prekocen i 4-terpineol, działały hamująco na wzrost A. flavus in vitro i in vivo oraz na produkcję aflatoksyny $\mathrm{B}_{1}$. Olejek z gwiazdnicy skuteczniej hamował produkcję aflatoksyny w hodowli grzyba na ziarnie soi, natomiast olejek z oregano działał skuteczniej w podłożu zawierającym ziarno kukurydzy [Esper i in. 2014].

Przeciwdrobnoustrojowe działanie olejków eterycznych: cynamonowego (85\% aldehydu cynamonowego), naturalnego i syntetycznego aldehydu cynamonowego (95- i 99-procentowego), olejku z Litsea citrate (85\% cytralu), cytralu (96\%), eugenolu (99\%), eukaliptusa ( $80 \%$ cyneolu), anyżu ( $92 \%$ anetolu), mięty pieprzowej ( $50 \%$ mentolu) i kamfory (55\% bomeolu) badano wobec $A$. ochraceus zdolnego do produkcji ochratoksyny A, stosując fumigację lub kontakt bezpośredni. Najbardziej efektywny okazał się naturalny aldehyd cynamonowy, dając całkowite zahamowanie wzrostu grzyba w stężeniach $150-250 \mu 1 \cdot 1^{-1}$ stosowanych poprzez fumigację lub w stężeniach $250-500 \mu l \cdot 1^{-1}$ podczas działania kontaktowego. Natomiast wartości MIC wynosiły dla prób z aldehydem cynamonowym $500 \mu \mathrm{l} \cdot \mathrm{l}^{-1}$. Przeciwdrobnoustrojowe działanie olejków potwierdziły zmiany morfologiczne strzępek. Wykazano negatywny wpływ olejków, zwłaszcza naturalnego aldehydu cynamonowego, na biosyntezę ergosterolu oraz produkcję ochratoksyny A związaną z ograniczeniem wzrostu grzybni [Hua i in. 2014]. 


\section{Ekstrakty roślinne w zakażeniach bakteryjnych}

Ekstrakty roślinne mają duży potencjał $\mathrm{w}$ walce $\mathrm{z}$ chorobotwórczymi mikroorganizmami. Ich najcenniejsze właściwości polegają na hamowaniu aktywności i wzrostu chorobotwórczych szczepów wywołujących zaburzenia równowagi mikrobiologicznej w organizmie człowieka. Działają zarówno na drobnoustroje powodujące zakażenia typu endogennego, jak i egzogennego. W grupie pierwszej występują m.in.: pałeczki E. coli, H. pylori, K. pneumoniae, ziarniaki S. aureus i Enterococcus spp. Wśród mikrobioty egzogennej pochodzącej ze środowiska zewnętrznego i wywołujacej zakażenia znajdują się m.in. pałeczki Salmonella, Shigella czy enteropatogenne szczepy E. coli. Zaliczamy tu także bakterie L. monocytogenes, $Y$. enterocolitica czy laseczki $B$. cereus. Szczególną grupę stanowią bakterie wywołujace choroby przenoszone drogą płciową takie jak: $N$. gonorrhoeae (rzeżączka), H. ducreyi (wrzód weneryczny miękki), M. hominis i $U$. urealyticum. Wiele $\mathrm{z}$ tych mikroorganizmów jest opornych na atybiotyki i w związku z tym zastosowanie ekstraktów roślinnych o działaniu bakteriobójczym czy bakteriostatycznym wydaje się być dobrą, alternatywną metodą leczenia zakażeń bakteryjnych.

Wśród ekstraktów wodnych o efektywnym działaniu bakteriobójczym, szczególnie wobec bakterii Gram-dodatnich, należy wymienić wyciągi z szałwii, rozmarynu i oregano. Ekstrakt z szałwii może być dodatkowo skutecznym środkiem konserwującym w przemyśle spożywczym ze względu na swoją wysoką antybakteryjną aktywność [Hać-Szymańczuk 2015a]. Ekstrakty etanolowe z rozmarynu i szałwii o stężeniu $40 \%$ również charakteryzowały się silnym działaniem bakteriobójczym wobec B. subtilis ATCC 6633, S. aureus ATTC 25923, E. coli ATTCC 25922, K. pneumoniae 196 czy S. Enteritidis ATTCC 13076. Powodem był skład chemiczny ekstraktów, zawierających kwas rozmarynowy, chlorogenowy, kawowy i rutozyd. Uzyskane wyniki badań wskazują na skuteczność zastosowania ekstraktów jako naturalnych konserwantów żywności [Hać-Szymańczuk 2015b]. 
Preparaty pozyskane z mięty pieprzowej odmiany „ASIA” również miały działanie bakteriobójcze. Wykazano, że olejek eteryczny, w którego składzie zidentyfikowano aż 45 substancji chemicznych, był skuteczniejszy w swoim bakteriobójczym działaniu od ekstraktu, który zawierał 15 substancji. Olejek eteryczny hamował wzrost szczepów chorobotwórczych $S$. aureus PCM 2054, S. aureus - szczep wieloantybiotykooporny i E. coli. Inni autorzy dowodzili, że działa on również na bakterie $P$. aeruginosa, ale nie wszystkie publikacje to potwierdziły [Kizil i in. 2010, Saković i in. 2010]. Jego skuteczność wobec badanych szczepów bakterii była również zauważalna, gdy stosowano olejek w stężeniu do 5-30\% [Jeyakumar i in. 2011]. Obserwowano także różnice w jego bakteriobójczym działaniu, które mogły być wynikiem odmiennego pochodzeniem surowca roślinnego i w związku z tym zróżnicowanego składu biochemicznego olejku z mięty pieprzowej.

Wyniki badań dotyczące wyciągów z czosnku są również obiecujące. Wskazują one na aktywność ekstraktu czosnkowego wobec bakterii Gram-dodatnich oraz Gram-ujemnych, w tym wielu szczepów chorobotwórczych. W tej grupie są również gronkowce enterotoksyczne (wytwarzające enterotoksyny A, B, C), szczepy antybiotykooporne, np. metycylinooporne bakterie S. aureus [Kędzia 2010]. Głównym składnikiem aktywnym w wyciągu czosnkowym jest allicyna, która jest skuteczna w walce $\mathrm{z}$ enterokokami opornymi na wankomycynę. W związku z tym obserwowano synergistyczne, przeciwdrobnoustrojowe działanie zarówno ekstraktu z czosnku, alliicyny i wankomycyny [Arora i Kaur 1999]. Podobne zjawisko potwierdził Ward i współpracownicy, którzy badali antybiotykooporne szczepy $S$. aureus, poddawane skutecznemu działaniu wyciągu z czosnku oraz antybiotyków takich jak ampicylina czy norfloksacyna. Stwierdzili, że ekstrakt czosnkowy w połączeniu z wybranym antybiotykiem działał synergistycznie, obniżając odporność szczepów na antybiotyk [Ward i in. 2002].

Ekstrakt z gorzkiego melona również wykazywał dużą aktywność antybakteryjną wobec wielu gatunków chorobotwórczych. Jednak większą aktywnością charakteryzował się ekstrakt otrzymany z owoców niedojrzałych niż z dojrzałych. Również dowiedziono, że etanolowe ekstrakty z owoców, nasion i oleju melona mają właściwości przeciwbakteryjne [Kulczyński i in. 2017].

Opisano również bakteriobójcze działanie ekstraktów z liści i korzeni mniszka lekarskiego. Najbardziej skuteczne były ekstrakty etanolowe, etanolo-octanowe i metanolowe w rozpuszczalnikach: chlorku metylenu, octanu etylu i octanu butylu z liści tej rośliny oraz etanolowe i metanolowe ekstrakty z korzeni. Wyciągi korzenne wykazywały silne bakteriobójcze działanie wobec Gram-dodatnich bakterii $S$. aureus czy B. cereus, natomiast były nieaktywne wobec Gram-ujemnych bakterii E. coli i S. Typhi. Natomiast ekstrakty wodne z liści mniszka lekarskiego nie hamowały skutecznie wzrostu większości bakterii z wyjątkiem E. coli i B. subtilis. Bardziej efektywnie działał wodny ekstrakt z korzeni tej rośliny [Lis i Grabek-Lejko 2016].

Wśród ekstraktów etanolowych z imbiru, kopru, tymianku, lubczyku, pietruszki i kwiatu nagietka najbardziej bakteriobójczy okazał się ten otrzymany z lubczyku. Hamował wzrost czterech szczepów chorobotwórczych S. aureus, E. coli, 


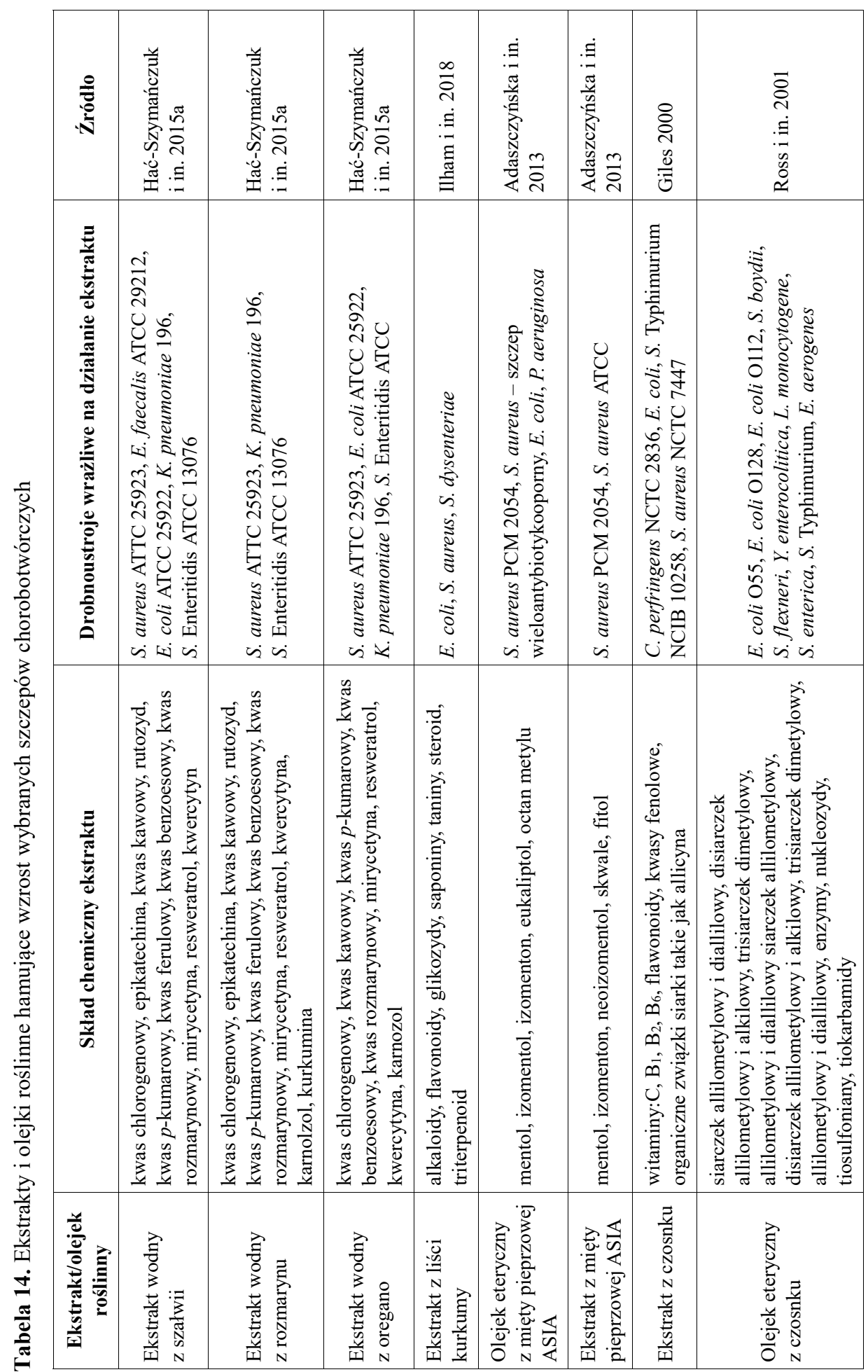




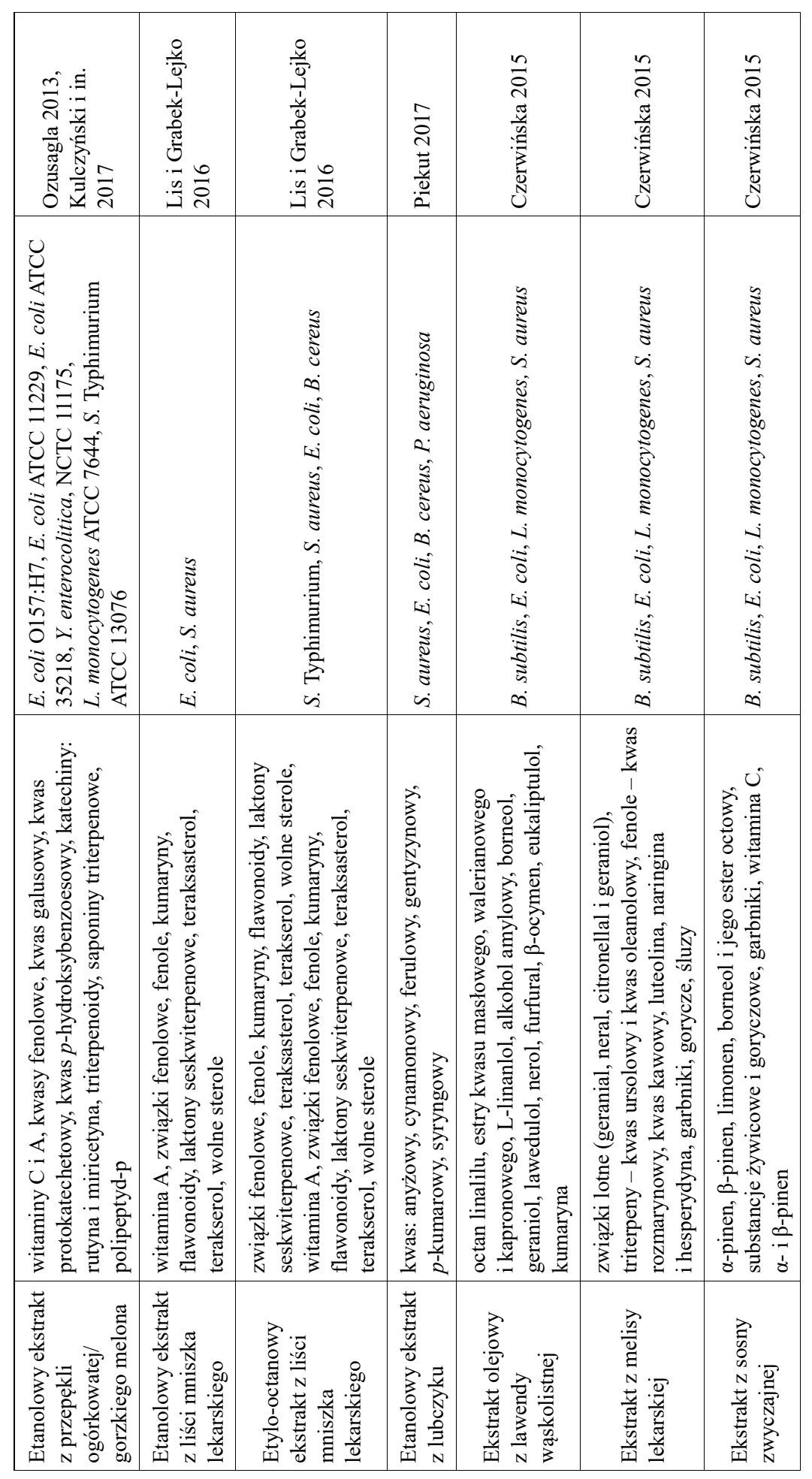


B. cereus i P. aeruginosa. Drugim z kolei, o podobnych właściwościach, był ekstrakt otrzymany z tymianku. Miał porównywalną zawartość kwasów fenolowych jak ekstrakt z lubczyku i wykazywał wysoką aktywność bakteriobójczą w stosunku do komórek E. coli i S. aureus [Piekut 2017].

Uważa się, że dotychczas najlepsze właściwości przeciwdrobnoustrojowe wykazują olejki eteryczne oraz wyciągi etanolowe z roślin przyprawowych [Suhaj 2006, Djeddi i in. 2007]. Część z nich jest nawet stosowana jako konserwanty, np. wyciągi z bazylii, pieprzu, lebiodki, goździków i szałwii. Pozostałe mogą w przyszłości stać się naturalnymi i bezpiecznymi konserwantami lub stabilizatorami żywności o bakteriobójczych lub bakteriostatycznych właściwościach.

Na szczególną uwagę zasługuje zastosowanie preparatów roślinnych w trudnych do wyleczenia zakażeniach $H$. pylori. Dotychczasowe leczenie tych zakażeń opierało się na stosowaniu inhibitorów pompy protonowej zmniejszających wydzielanie soków żołądkowych w połączeniu z antybiotykami: amoksycyliną, klarytromycyną, teracykliną oraz chemioterapeutykami: metronidazolem i tynidazolem. Niestety u 10-20\% pacjentów nie obserwowano pozytywnych skutków leczenia z powodu oporności szczepów na stosowane leki. Badania wykazują jednak skuteczność hamowania wzrostu $H$. pylori w wyniku użycia różnych wyciągów roślinnych. Wśród nich wymienia się te otrzymane z czosnku, żurawiny, oregano, brokułu, zielonej herbaty chińskiej, kurkumy, cynamonowca wonnego, akacji, zielonych skórek winogron, soku z jabłek i piwonii chińskiej [Takeuchi i in. 2014].

Ponadto dowiedziono, że Citrosept w stężeniu $0,1 \mathrm{mg}$ i roztwór witaminy $\mathrm{C}-$ $1 \mathrm{mg}$ hamowały wzrost szczepu $H$. pylori. Zastosowanie Citroseptu w ilości 0,1 mg lub $1 \mathrm{mg}$ oraz $50 \mu \mathrm{g} \cdot \mathrm{cm}^{-3}$ sorbinianu potasu powodowało takie same pozytywne efekty. Alliofil w stężeniu $100 \mu \mathrm{g} \cdot \mathrm{cm}^{-3}$ całkowicie ograniczał wzrost $H$. pylori, to samo zjawisko obserwowano przy stężeniu Alliofilu $1 \mathrm{mg} \cdot \mathrm{cm}^{-3} \mathrm{~W}$ mieszaninie z sorbinianem potasu $0,5 \mathrm{mg} \cdot \mathrm{cm}^{-3}$ [Maćkiw i in. 2012]. Ekstrakt z cynamonowca wonnego zawierający aldehyd cynamonowy w stężeniu $\geq 500 \mu \mathrm{g} \cdot \mathrm{cm}^{-3}$ również hamował wzrost chorobotwórczego szczepu [Muhammad i in. 2015]. Bardzo dobre wyniki otrzymywano, stosując 0,5\% i 1\% ekstrakt z herbaty chińskiej, który dodawano przed rozpoczęciem hodowli H. pylori, jak i po jej zakończeniu. W obu przypadkach obserwowano strefy zahamowania wzrostu chorobotwórczej bakterii [Stoicov i in. 2009]. Przykłady (tab. 15) dowodzą, że istnieją alternatywne sposoby leczenia H. pylori poza obowiązującymi antybiotykami i chemioterapeutykami.

Inną grupą preparatów roślinnych są wyciągi charakteryzujące się wysoką aktywnością wobec szczepów wywołujących choroby bakteryjne przenoszone drogą płciową. Wśród tych drobnoustrojów należy wymienić $N$. gonorrhoeae (rzeżączka), H. ducreyi (wrzód weneryczny miękki), M. hominis, U. urealyticum (zapalenie cewki moczowej).

Jadhav i in. [2014] stosowali dwie metody badania aktywności antybakteryjnej ekstraktów roślinnych z migdałecznika. Oznaczali strefy inhibicji metodą dyfuzji krążków agarowych $(\mathrm{mm})$ oraz badali najniższe stężenie wyciągu roślinnego 


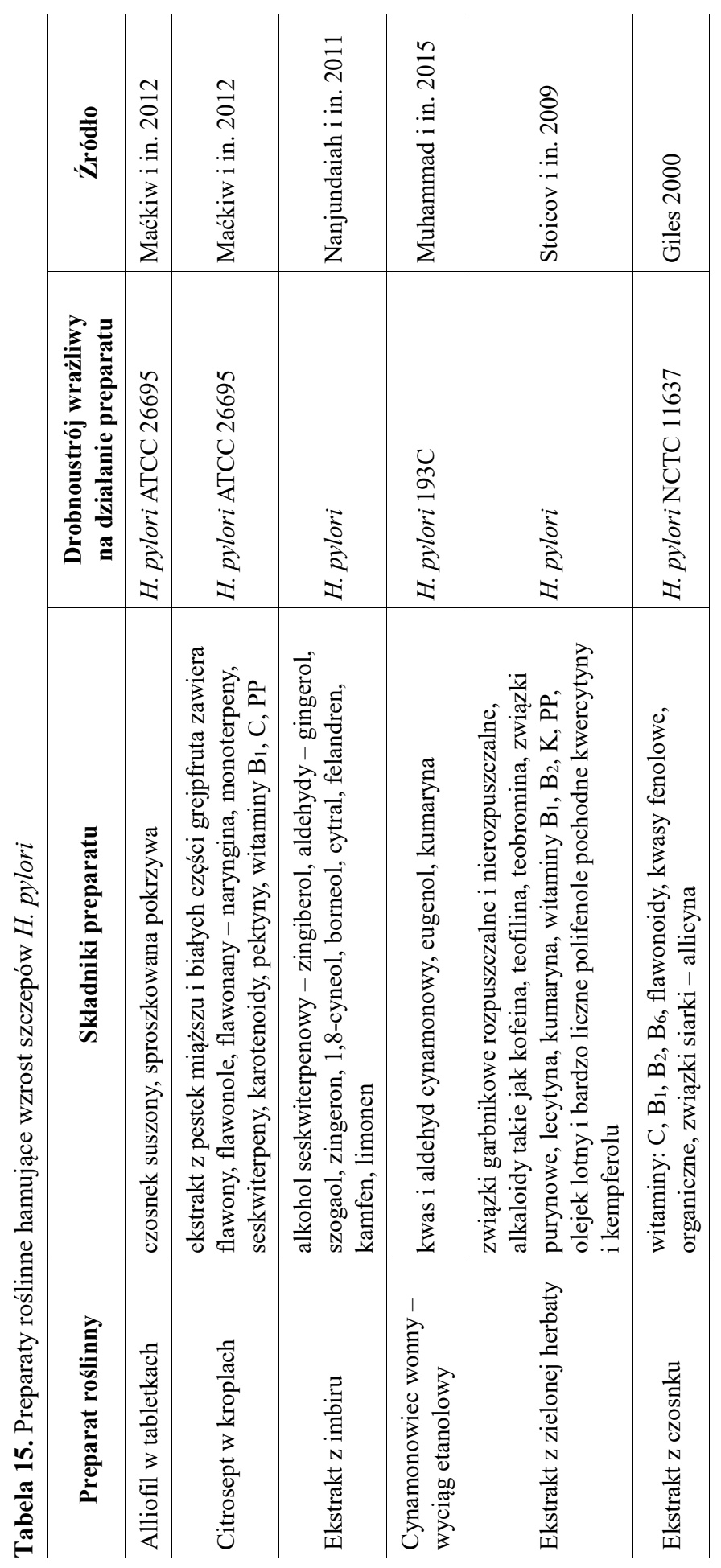


Tabela 16. Aktywność przeciwdrobnoustrojowa ekstraktów z roślin przeciw patogenom przenoszonym drogą płciową

\begin{tabular}{|c|c|c|c|}
\hline $\begin{array}{l}\text { Nazwa botaniczna } \\
\text { rośliny }\end{array}$ & $\begin{array}{l}\text { Część rośliny użyta do } \\
\text { przygotowania ekstraktu }\end{array}$ & $\begin{array}{c}\text { Drobnoustrój wrażliwy } \\
\text { na działanie ekstaktu }\end{array}$ & Źródlo \\
\hline $\begin{array}{l}\text { Terminalia } \\
\text { paniculat/ } \\
\text { migdałecznik }\end{array}$ & owoce & $\begin{array}{l}\text { N. gonorrhoeae ATCC, } \\
\text { N. gonorrhoeae (szczep } \\
\text { laboratoryjny), H. ducreyi } \\
\text { ATCC }\end{array}$ & $\begin{array}{l}\text { Jadhav } \mathrm{i} \text { in. } \\
2014\end{array}$ \\
\hline $\begin{array}{l}\text { Terminalia } \\
\text { crenulatal } \\
\text { migdałecznik }\end{array}$ & owoce & $\begin{array}{l}\text { N. gonorrhoeae ATCC, } \\
\text { N. gonorrhoeae (szczep } \\
\text { laboratoryjny) }\end{array}$ & $\begin{array}{l}\text { Jadhav } \mathrm{i} \text { in. } \\
2014\end{array}$ \\
\hline $\begin{array}{l}\text { Cuscuta reflexal } \\
\text { kanianka }\end{array}$ & kora & $\begin{array}{l}\text { N. gonorrhoeae ATCC, } \\
\text { N. gonorrhoeae (szczep } \\
\text { laboratoryjny), H. ducreyi } \\
\text { ATCC }\end{array}$ & $\begin{array}{l}\text { Jadhav } \mathrm{i} \text { in. } \\
2014\end{array}$ \\
\hline Bridelia retusa & kora & $\begin{array}{l}\text { N. gonorrhoeae ATCC, } \\
\text { N. gonorrhoeae (szczep } \\
\text { laboratoryjny), H. ducreyi } \\
\text { ATCC }\end{array}$ & $\begin{array}{l}\text { Jadhav } \mathrm{i} \text { in. } \\
2014\end{array}$ \\
\hline $\begin{array}{l}\text { Syzygium cumini/ } \\
\text { czapetka kuminowa }\end{array}$ & liście & $\begin{array}{l}\text { N. gonorrhoeae ATCC, } \\
\text { N. gonorrhoeae (szczep } \\
\text { laboratoryjny), H. ducreyi } \\
\text { ATCC }\end{array}$ & $\begin{array}{l}\text { Jadhav } \mathrm{i} \text { in. } \\
2014\end{array}$ \\
\hline $\begin{array}{l}\text { Calendula } \\
\text { officinalis/ nagietek } \\
\text { lekarski }\end{array}$ & kwiat & $\begin{array}{l}\text { U. urealyticum, } \\
\text { M. hominis }\end{array}$ & $\begin{array}{l}\text { Oreščanin i in. } \\
2015\end{array}$ \\
\hline Vitis/ winorośl & $\begin{array}{l}\text { owoce (ciemne, skórki) } \\
\text { resweratrol }\end{array}$ & H. ducreyi & $\begin{array}{l}\text { Nawrocki i in. } \\
2013\end{array}$ \\
\hline $\begin{array}{l}\text { Allium sativum/ } \\
\text { czosnek }\end{array}$ & cebula & N. gonorrhoeae & Kędzia 2010 \\
\hline $\begin{array}{l}\text { Distemonanthus } \\
\text { benthamianus }\end{array}$ & kora & N. gonorrhoeae & $\begin{array}{l}\text { Obiang } \mathrm{i} \text { in. } \\
2019\end{array}$ \\
\hline Solanum torvu & owoce & N. gonorrhoeae & $\begin{array}{l}\text { Obiang } \mathrm{i} \text { in. } \\
2019\end{array}$ \\
\hline
\end{tabular}

( $\mathrm{MCC}$ - minimum chlamycidum concentration) hamujące rozwój Chlamydia ( $\mu \mathrm{m}$. $\mathrm{cm}^{-3}$ ). W zależności od zastosowanych szczepów: $H$. ducreyi ATCC, $N$. gonorrhoeae ATCC czy N. gonorrhoeae (szczep laboratoryjny) oraz wykorzystanej metody osiągano różne wyniki świadczące o braku działania lub efektywnym działaniu 
ekstraktów roślinnych. Większość zastosowanych ekstraktów z migdałecznika była skuteczna i hamowała wzrost badanych bakterii chorobotwórczych [Jadhav i in. 2014].

Ruddock i in. [2005] oznaczyli skład 19 naturalnych preparatów z czosnku i 5 ekstraktów ze świeżego czosnku, a także ich działanie przeciwbakteryjne. Preparaty ekstrahowano przez 5,10 lub 15 min w wodzie i rozcieńczano do stężenia $200 \mathrm{mg} \cdot \mathrm{cm}^{-3}$. Minimalne stężenia hamujące ekstraktu (MIC) i minimalne stężenia bakteriobójcze (MBC) badano wobec trzech wskaźnikowych mikroorganizmów: $N$. gonorrhoeae, S. aureus i E. faecalis. Podczas gdy 47\% wodnych ekstraktów czosnkowych wykazywało aktywność przeciwko $N$. gonorrhoeae, tylko $16 \%$ hamowało $S$. aureus lub E. faecalis. Zasadniczo produkty o wysokiej aktywności przeciwdrobnoustrojowej zawierały więcej składników czosnku o działaniu porównywalnym do wyciągów ze świeżego czosnku, podczas gdy produkty o marginalnej aktywności przeciwbakteryjnej często zawierały niższe stężenia składników niż wskazano na etykietach produktów. Różne czasy ekstrakcji wpływały na działanie przeciwbakteryjne tylko przeciwko N. gonorrhoeae i miały tendencję do korelacji z poziomem allicyny. Wiele ekstraktów wykazywało rozbieżności zarówno w składzie, stosunku allicyny do alliiny, jak i działaniu przeciwdrobnoustrojowym, co budzi obawy co do standardów przygotowania i kontroli jakości tych produktów [Ruddock i in. 2005].

Badano również ekstrakty wodne, wodno-etanolowe i wodno-acetonowe pozyskane z kory drzewa Distemonanthus benthamianus i owoców Solanum torvu, roślin rosnących w Gabonie. Testy wrażliwości bakterii $N$. gonorrhoeae przeprowadzono odpowiednio na podłożu Muellera Hintona i stałym Sabouraud, stosując metodę dyfuzyjną i minimalnych stężeń hamujących. We wszystkich testach szczep $N$. gonorrhoeae wykazywał wrażliwość na zastosowane ekstrakty. Jednak najskuteczniejsze działanie bakteriobójcze osiągano, wykorzystując ekstrakty wodno-etanolowe i wodno-acetonowe z wyżej wymienionych części roślin [Obiang i in. 2019].

Dotychczasowe standardowe leczenie zakażeń bakteryjnych antybiotykami i chemiofarmaceutykami bywa zawodne. Wiąże się to z obecnością szczepów antybiotykoopornych i powstawaniem efektów ubocznych w postaci nietolerancji składników leków u niektórych pacjentów. Powoduje to zmniejszenie efektywności terapii i szybki nawrót choroby. Dlatego terapia alternatywna związkami z ekstraktów pochodzenia roślinnego może się stać nową formą leczenia wspomagającego dla obecnie istniejącej wielolekowej terapii zakażeń bakteryjnych. 


\section{Oddziaływania ekstraktów roślinnych na drobnoustroje probiotyczne}

\section{Drobnoustroje probiotyczne}

W ostatnich latach wzrosło zainteresowanie preparatami probiotycznymi, które zawierają drobnoustroje o właściwościach prozdrowotnych. Najczęściej są stosowane $\mathrm{w}$ antybiotykoterapii lub $\mathrm{w}$ dysbiozach jelitowych. Wpływają pozytywnie na homeostazę przewodu pokarmowego.

Termin „probiotyk”, z języka greckiego pro bios, oznacza „dla życia”. W 1965 r. po raz pierwszy zaproponowano (Daniel Lilly i Rosalie Stillwell) tak ą nazwę dla szeregu mikroorganizmów, które korzystnie oddziałują na wzrost innych gatunków bakterii wpływających pozytywnie na zdrowie gospodarza [Markowiak i Śliżewska 2017]. Według Międzynarodowego Towarzystwa Naukowego ds. Probiotyków i Prebiotyków (ISAPP) oraz WHO drobnoustroje probiotyczne to „żywe drobnoustroje, które podawane w odpowiednich ilościach wywołują korzystny skutek zdrowotny u gospodarza" [Hill i in. 2014]. Należy jednak zaznaczyć, że właściwości probiotyczne są cechą szczepową, a nie rodzajową czy gatunkową. Ilja Miecznikow jako pierwszy rozpoczął badania nad kulturami probiotycznymi. Stwierdził, że spożycie kwaśnego mleka obfitującego w bakterie kwasu mlekowego sprzyjało zdrowiu i zachowaniu równowagi mikrobiologicznej jelit, a także zaobserwował, że poszczególne gatunki bakterii hamowały bądź stymulowały wzrost innych gatunków [Kubiszewska i in. 2014].

Pierwszym, który prowadził w Polsce badania nad zastosowaniem bakterii kwasu mlekowego w chorobach jelit u niemowląt, był pediatra i neurolog Józef Brudziński. Inni badacze, Zychowicz i Cieplińska, w 1972 r. prowadzili obserwacje dotyczące wpływu fermentowanego preparatu mlecznego na ustąpienie objawów jelitowych spowodowanych przez epidemię czerwonki u dzieci. Po raz pierwszy 
zastosowali fermentowany preparat mleczny, który zawierał bakterie L. acidophilus, nazwany potem mlekiem acidofilnym. Pod wpływem zastosowanego leczenia u dzieci nastąpiła znaczna poprawa apetytu oraz większa odporność na infekcje dróg oddechowych [Zychowicz i Cieplińska 2002]. Podawanie probiotyków stało się więc nową metodą terapeutyczną w leczeniu i profilaktyce chorób u dzieci i dorosłych [Plaza-Díaz i in. 2018].

Najczęściej u ludzi stosuje się jako probiotyki bakterie fermentacji mlekowej (tab. 17) z rodzaju Lactobacillus (tj.: L. acidophilus, L. amylovorus, L. plantarum, L. casei, L. paracasei, L. gasseri, L. johnsoni, L. reuteri, L. rhamnosus) i Bifidobacterium (tj.: B. adolescentis, B. animalis, B. bifidum, B. breve, B. longum, $B$. infantis) oraz $S$. salivarius ssp. thermophilus, L. lactis [Gawęcki i Libudzisz 2006]. Wśród drożdży probiotycznych wykorzystuje się najczęściej $S$. cerevisiae (boulardii). Probiotyki w Polsce występują w postaci leków OTC (bez recepty), suplementów diety lub dodatków do żywności. Ponadto, aby mogły być stosowane, muszą posiadać tzw. status GRAS (generally regarded as safe) [Klaenhammer 2000].

Każdy probiotyk, który jest dopuszczony do spożycia, musi spełniać określone wymagania. Powinien:

- być wyizolowany z przewodu pokarmowego człowieka,

- mieć ustaloną metodami genetycznymi przynależność rodzajową i gatunkową oraz być zdeponowany w renomowanej kolekcji szczepów,

- posiadać dokumentację naukową i wyniki badań klinicznych w renomowanych czasopismach,

- być niechorobotwórczy, nieinwazyjny oraz niekarcynogenny,

- posiadać odporność na niskie pH soku żołądkowego oraz działanie enzymów trawiennych i żółci po podaniu doustnym,

- mieć zdolność adhezji do komórek nabłonka jelitowego i kolonizacji jelita człowieka,

- mieć wysoką żywotność i zdolność do szybkiego namnażania w jelitach,

- wykazywać antagonistyczną aktywność wobec typowych patogenów przewodu pokarmowego,

- mieć wysoką skuteczność w oddziaływaniu na organizm człowieka i bezpieczeństwo potwierdzone in vitro i w badaniach klinicznych z zastosowaniem placebo, randomizacji i podwójnie ślepej próby,

- charakteryzować się aktywnością probiotyczną po procesie technologicznym i w czasie przechowywania [Jach i in. 2013]. 
Tabela 17. Lista szczepów bakterii fermentacji mlekowej o udokumentowanych właściwościach probiotycznych [opracowano na podstawie: Gawęcki i Libudzisz 2006, Nowak i in. 2010]

\begin{tabular}{|c|c|c|}
\hline $\begin{array}{c}\text { Gatunek i rodzaj } \\
\text { szczepu probiotycznego }\end{array}$ & Numer szczepu & Firma będąca właścicielem szczepu \\
\hline L. acidophilus & $N C F M^{R}$ & Rhodia, Inc. (Medioson, WI) \\
\hline L. acidophilus & DDS-1 & Nebraska Cultures, Inc. (Lincoln, NE) \\
\hline L. acidophilus & SBT-2062 & $\begin{array}{l}\text { Snow Brand Milk Production Co., Ltd. (Tokyo, } \\
\text { Japan) }\end{array}$ \\
\hline L. acidophilus & R0011 & Institut Rosell (Montreal, Canada) \\
\hline L. acidophilus & LA-1 & Chr. Hansen (Hørsholm, Denmark) \\
\hline L. acidophilus & LB & Lacteol Laboratory (Houdan, France) \\
\hline L. casei & Shirota & Yakult (Tokyo, Japan) \\
\hline L. casei & DN-114001 & Danone (Paris, France) \\
\hline L. fermentum & RC-14 & Urex Biotech (London, Ontario, Canada) \\
\hline L. johnsonii & La1 (Lj1) & Nestlé (Lausanne, Switzerland) \\
\hline L. plantarum & $299 \mathrm{~V}$ & Probi AB (Lund, Sweden) \\
\hline L. paracasei & CRL-431 & Chr. Hansen (Hørsholm, Denmark) \\
\hline L. paracasei & F19 & Arla Dairy (Stockholm, Sweden) \\
\hline L. reuteri & SD2112 & Biogaia (RALEIGH, NC) \\
\hline L. rhamnosus & R0052 & Institut Rosell (Montreal, Canada) \\
\hline L. rhamnosus & GR-1 & Urex Biotech (London, Ontario, Canada) \\
\hline L. rhamnosus & 271 & Probi AB (Lund, Sweden) \\
\hline L. rhamnosus & GG & Valio Dairy (Helsinki, Finland) \\
\hline L. rhamnosus & LB21 & Essum AB (Umea, Sweden) \\
\hline L. salivarius & UCC118 & University College (Cork, Ireland) \\
\hline L. lactis & L1A & Essum AB (Umea, Sweden) \\
\hline B. animalis & DN-173 010 & Danone (Paris, France) \\
\hline B. animalis & HN019(DR 10) & New Zealand Dairy Board \\
\hline B. breve & Yakult & Yakult (Tokyo, Japan) \\
\hline B. longum & BB536 & $\begin{array}{l}\text { Morinaga Milk Industry Co., Ltd. (Zama-City, } \\
\text { Japan) }\end{array}$ \\
\hline B. longum & SBT-2928 & $\begin{array}{l}\text { Snow Brand Milk Production Co., Ltd. (Tokyo, } \\
\text { Japan) }\end{array}$ \\
\hline S. cerevisiae (boulardii) & $\begin{array}{l}\text { lyo (DiarSafe, } \\
\text { Ultravure i in.) }\end{array}$ & Biocodex (Creswell OR) \\
\hline S. cerevisiae (boulardii) & $\begin{array}{l}\text { (Florastor) } \\
\text { Biocodex (Creswell } \\
\text { OR) }\end{array}$ & Biocodex (Creswell OR) \\
\hline
\end{tabular}




\section{Dzialanie preparatów roślinnych na probiotyczne kultury bakterii fermentacji mlekowej}

Dotychczas prowadzono badania głównie dotyczące bakteriobójczego lub grzybobójczego zastosowania ekstraktów roślinnych na chorobotwórcze grzyby i bakterie występujące w organizmie człowieka jako alternatywy dla antybiotykoterapii. Jednak interesujące jest również ich oddziaływanie na pożyteczną florę bakteryjną przewodu pokarmowego człowieka, przede wszystkim drobnoustrojów fermentacji mlekowej z rodzajów Lactobacillus, Bifidobacterium i Streptococcus. W tym celu zbadano stosowanie preparatów roślinnych równocześnie z probiotykami, aby sprawdzić czy nie istnieją między nimi interakcje o charakterze antagonistycznym, co mogłoby być przeciwwskazaniem do ich wspólnego stosowania. W sumie przebadano 35 handlowych preparatów roślinnych i suplementów diety o przeciwdrobnoustrojowym działaniu oraz sześć szczepów wzorcowych bakterii mlekowych pochodzących z kolekcji ATCC, tj.: L. acidophilus ATCC 4356, L. casei ATCC 393, L. rhamnosus Hansen 1968, B. bifidum ATCC 35914, S. salivarius ssp. thermophilus ATCC 14485 [Kędzia 2012]. Zastosowane substancje roślinne występowały w postaci kapsułek, past, tabletek, drażetek, pastylek, kropli, płynu oraz syropu. W celu przeprowadzenia badań, preparaty odważano w ilości $2 \mathrm{~g}$ i zawieszano w $20 \mathrm{~cm}^{3}$ podłoża płynnego RCM (Reinforced Clostridial Medium), a następnie wprowadzano wybraną hodowlę wzorcowych drobnoustrojów w ilości $10^{5}-10^{6}$ komórek $\cdot \mathrm{cm}^{-3}$. Pobrano próbki kontrolne, a pozostałą część hodowli inkubowano $\mathrm{w}$ temperaturze pokojowej przez $60 \mathrm{~min}$. Po tym czasie ponownie pobrano próbki hodowli z probiotykami i wykonano posiewy drobnoustrojów na płytki Petriego z próby kontrolnej i po 60 min na następujące podłoża: MRS dla Lactobacillus i Streptococcus, BHB dla drożdży i BSM dla Bifidobacterium. Płytki inkubowano w warunkach beztlenowych w temperaturze $37^{\circ} \mathrm{C}$ przez 3-5 dni. Potem oznaczano liczbę kolonii mikroorganizmów probiotycznych wyrosłych na podłożach z kontrolą i po 60 min hodowli. W ten sposób wyznaczono wpływ badanego preparatu na drobnoustroje probiotyczne.

Przebadane preparaty farmaceutyczne sklasyfikowano w trzech grupach:

- preparaty, które działały jak prebiotyki i wzmagały namnażanie probiotycznych bakterii mlekowych (tab. 18),

- preparaty obojętne dla badanych bakterii (tab. 19)

- preparaty, które hamowały rozwój bakterii fermentacji mlekowej, tj.: Lactobacillus, Bifidobacterium i Streptococcus (tab. 20).

Wymienione preparaty roślinne (tab. 18) oddziaływują prebiotycznie, stymujlując do wzrostu szczepy: L. acidophilu ATCC 4356, L. casei ATCC 393, L. rhamnosus Hansen 1968, B. bifidum ATCC i S. salivarius ssp. thermophilus ATCC 14485. W związku z tym korzystnie jest stosować je szczególnie w połączeniu z tymi probiotykami. 
Tabela 18. Farmaceutyczne preparaty roślinne wzmagające namnażanie wybranych szczepów bakterii z rodzaju Lactobacillus, Bifidobacterium i Streptococcus [opracowano na podstawie: Hołderna-Kędzia i Kędzia 2012]

\begin{tabular}{|c|c|c|}
\hline $\begin{array}{l}\text { Preparat pochodzenia } \\
\text { roślinnego }\end{array}$ & Składniki biologicznie aktywne & $\begin{array}{l}\text { Szczep bakterii } \\
\text { probiotycznych }\end{array}$ \\
\hline Ginjal - kapsułki & $\begin{array}{l}\text { wyciąg z konika morskiego Hippocampus } \\
\text { coronatus, korzenia żeń-szenia oraz liści } \\
\text { mlecza, liści ortosyfonu, liści Strobilanthes }\end{array}$ & $\begin{array}{l}\text { L. acidophilus ATCC } \\
4356\end{array}$ \\
\hline Septolete - drażetki & chlorek benzalkoniowy, mentol, tymol & $\begin{array}{l}\text { L. acidophilus ATCC } \\
4356\end{array}$ \\
\hline Olbas - pastylki & $\begin{array}{l}\text { olejki eteryczne: eukaliptusowy, goździkowy, } \\
\text { kajeputowy, jałowcowy, miętowy, brzozowy, } \\
\text { mentol }\end{array}$ & $\begin{array}{l}\text { L. acidophilus ATCC } \\
4356\end{array}$ \\
\hline Pollen - kapsułki & pyłek kwiatowy sproszkowany & $\begin{array}{l}\text { L. acidophilus ATCC } \\
4356\end{array}$ \\
\hline $\begin{array}{l}\text { Apigardin Forte - } \\
\text { pastylki }\end{array}$ & wyciąg z propolisu, macerat z prawoślazu & $\begin{array}{l}\text { L. acidophilus ATCC } \\
4356\end{array}$ \\
\hline Propolis Plus - kapsułki & wyciąg z propolisu, pyłek kwiatowy & $\begin{array}{l}\text { B. bifidum ATCC } \\
35914\end{array}$ \\
\hline Alliofil - drażetki & $\begin{array}{l}\text { czosnek suszony, liść pokrzywy } \\
\text { sproszkowany }\end{array}$ & $\begin{array}{l}\text { L. rhamnosus Hansen } \\
\text { 1968, B. bifidum } \\
\text { ATCC } 35914\end{array}$ \\
\hline Alax - drażetki & $\begin{array}{l}\text { alona - zagęszczony sok z liści aloesu, } \\
\text { wyciąg z kory kruszyny }\end{array}$ & $\begin{array}{l}\text { L. casei } \mathrm{ATCC} 393 \text {, } \\
\text { L. rhamnosus Hansen } \\
1968\end{array}$ \\
\hline Nursea - tabletki & $\begin{array}{l}\text { wyciąg z kłącza ostryża długiego i ziela } \\
\text { karczocha }\end{array}$ & $\begin{array}{l}\text { S. salivarius } \text { ssp. } \\
\text { thermophilus ATCC } \\
14485, \text { L. casei } \\
\text { ATCC } 393\end{array}$ \\
\hline Terpichol & $\begin{array}{l}\text { mentol, menton, } \alpha \text {-pinen, cyneol, } \\
\text { kamfenmentol, menton, } \alpha \text {-pinen, cyneol, } \\
\text { kamfen }\end{array}$ & $\begin{array}{l}\text { S. salivarius ssp. } \\
\text { thermophilus ATCC } \\
14485\end{array}$ \\
\hline Uroval manosa & wyciąg z wielkoowocowej żurawiny & $\begin{array}{l}\text { S. salivarius ssp. } \\
\text { thermophilus ATCC } \\
14485\end{array}$ \\
\hline
\end{tabular}


Tabela 19. Farmaceutyczne preparaty roślinne obojętne wobec szczepów bakterii z rodzaju Lactobacillus, Bifidobacterium i Streptococcus [opracowano na podstawie: Hołderna-Kędzia i Kędzia 2012]

\begin{tabular}{|c|c|c|}
\hline $\begin{array}{l}\text { Preparat pochodzenia } \\
\text { roślinnego }\end{array}$ & Składniki biologicznie obojętne & $\begin{array}{l}\text { Szczep bakterii } \\
\text { probiotycznych }\end{array}$ \\
\hline Amol - płyn & $\begin{array}{l}\text { olejki eteryczne: cytrynowy, } \\
\text { goździkowy, cynamonowy, } \\
\text { cytronelowy, z mięty pieprzowej, } \\
\text { lawendowy, mentol }\end{array}$ & L. acidophilus ATCC 4356 \\
\hline Azulan - płyn & wyciąg z koszyczków rumianku & L. acidophilus ATCC 4356 \\
\hline Alliofil - drażetki & $\begin{array}{l}\text { czosnek suszony, sproszkowany liść } \\
\text { pokrzywy }\end{array}$ & L. casei ATCC 393 \\
\hline Solaren - płyn & wyciąg z kłącza kurkumy & L. acidophilus ATCC 4356 \\
\hline Nefrol - płyn & $\begin{array}{l}\text { wyciąg z korzenia marzanny } \\
\text { barwierskiej, owocu aminku } \\
\text { egipskiego, ziela nawłoci, mniszka, } \\
\text { pietruszki, fasoli, jeżówki }\end{array}$ & L. acidophilus ATCC 4356 \\
\hline $\begin{array}{l}\text { Nursea trawienie - } \\
\text { tabletki }\end{array}$ & $\begin{array}{l}\text { wyciąg z kłącza ostryża długiego } \\
\text { i ziela karczocha }\end{array}$ & L. rhamnosus Hansen 1968 \\
\hline Fitolizyna - pasta & $\begin{array}{l}\text { wyciąg z kłącza perzu, łusek czosnku, } \\
\text { liści brzozy, nasion kozieradki, korzeni } \\
\text { pietruszki, lubczyku, ziela nawłoci, } \\
\text { skrzypu i rdestu ptasiego }\end{array}$ & L. acidophilus ATCC 4356 \\
\hline Persen Forte - kapsułki & $\begin{array}{l}\text { wyciąg z korzenia kozłka, szyszek } \\
\text { chmielu, ziela melisy }\end{array}$ & L. acidophilus ATCC 4356 \\
\hline Urinal - kapsułki & wyciąg z owoców żurawiny błotnej & L. acidophilus ATCC 4356 \\
\hline Urosept - drażetki & $\begin{array}{l}\text { wyciąg z korzenia pietruszki, naowocni } \\
\text { fasoli, liści brzozy, borówki brusznicy, } \\
\text { koszyczków rumianku }\end{array}$ & $\begin{array}{l}\text { L. casei ATCC } 393 \text {, } \\
\text { L. rhamnosus Hansen } 1968 \text {, } \\
\text { S. salivarius ssp. } \\
\text { thermophilus ATCC } 14485 \text {, } \\
\text { B. bifidum ATCC } 14485\end{array}$ \\
\hline $\begin{array}{l}\text { Uroval manosa - } \\
\text { kapsułki }\end{array}$ & wyciąg z żurawiny wielkoowocowej & $\begin{array}{l}\text { L. casei ATCC 393, } \\
\text { L. rhamnosus Hansen } 1968\end{array}$ \\
\hline Xenna - tabletki & wyciąg z listków senesu & L. acidophilus ATCC 4356 \\
\hline Venescin - drażetki & eskulina, rutyna, wyciąg z kasztanowca & L. acidophilus ATCC 4356 \\
\hline Boldaloin - tabletki & alkaloid z liści boldo, wyciąg z aloesu & L. acidophilus ATCC 4356 \\
\hline Raphacholin C - drażetki & $\begin{array}{l}\text { wyciąg z korzenia czarnej rzodkwi } \\
\text { i ziela karczocha, kwas } \\
\text { dehydrocholowy, olejek z mięty } \\
\text { pieprzowej }\end{array}$ & L. acidophilus ATCC 4356 \\
\hline Radirex - tabletki & korzeń rzewienia sproszkowany & L. acidophilus ATCC 4356 \\
\hline
\end{tabular}




\begin{tabular}{|c|c|c|}
\hline $\begin{array}{l}\text { Sirupus Thymi comp. - } \\
\text { syrop }\end{array}$ & wyciąg z tymianku, tymol & L. acidophilus ATCC 4356 \\
\hline Propolki - pastylki & $\begin{array}{l}\text { wyciąg z propolisu, olejek z trawy } \\
\text { cytrynowej, wyciąg z aloesu i imbiru, } \\
\text { mentol }\end{array}$ & L. acidophilus ATCC 4356 \\
\hline Borówka - kapsułki & sproszkowany owoc borówki czernicy & L. acidophilus ATCC 4356 \\
\hline $\begin{array}{l}\text { Wierzbownica } \\
\text { drobnokwiatowa- } \\
\text { tabletki }\end{array}$ & $\begin{array}{l}\text { ziele wierzbownicy, wyciąg z ziela } \\
\text { wierzbownicy }\end{array}$ & L. acidophilus ATCC 4356 \\
\hline Oliwka - kapsułki & wyciąg z liści oliwki & L. acidophilus ATCC 4356 \\
\hline $\begin{array}{l}\text { Tymianek z podbiałem - } \\
\text { pastylki }\end{array}$ & $\begin{array}{l}\text { wyciąg z ziela tymianku i liści } \\
\text { podbiału }\end{array}$ & L. acidophilus ATCC 4356 \\
\hline Akron Sept - tabletki & $\begin{array}{l}\text { olej z owoców rokitnika, wyciąg } \\
\text { z prawoślazu i aloesu, bioflawonoidy } \\
\text { cytrusowe }\end{array}$ & L. acidophilus ATCC 4356 \\
\hline Terpichol - kapsułki & $\begin{array}{l}\text { mentol, menton, } \alpha \text {-pinen, cyneol, } \\
\text { kamfen }\end{array}$ & $\begin{array}{l}\text { L. casei ATCC } 393 \text {, } \\
\text { L. acidophilus ATCC 393, } \\
\text { L. rhamnosus Hansen } 1968\end{array}$ \\
\hline Propolis Plus - tabletki & wyciąg z propolisu, pyłek kwiatowy & $\begin{array}{l}\text { L. casei ATCC } 393 \text {, } \\
\text { L. acidophilus ATCC } 393 \text {, } \\
\text { L rhamnosus Hansen 1968, } \\
\text { S salivarius } \text { ssp. } \\
\text { thermophilus ATCC } 14485\end{array}$ \\
\hline
\end{tabular}

Z przeprowadzonych badań wynika, że wszystkie wymienione w tabeli 19 preparaty są obojętne w stosunku do szczepów: L. acidophilus ATCC 4356, L. casei ATCC 393, L. rhamnosus Hansen 1968, B. bifidum ATCC i S. salivarius ssp. thermophilus ATCC 14485, co pokazuje, że nie ma żadnych przeciwskazań $\mathrm{w}$ ich stosowaniu razem z wyżej wymienionymi kulturami pobiotycznymi.

Jedynie preparaty rośline Pectosol krople i Tinctura Salviae płyn (tab. 20) zdecydowanie hamowały wzrost probiotycznych bakterii: L. acidophilus ATCC 4356, L. casei ATCC 393, L. rhamnosus Hansen 1968, B. bifidum ATCC i S. salivarius ssp. thermophilus ATCC 14485. W związku z tym nie należy zalecać ich stosowania razem z wyżej wymienionymi probiotykami.

\section{Działanie preparatów roślinnych na probiotyczne drożdże $S$. cerevisiae (boulardii)}

Obecnie w leczeniu osób dorosłych i dzieci oprócz bakterii fermentacji mlekowej stosuje się szczepy drożdży probiotycznych: $S$. cerevisiae (boulardii) lyophylized, S. cerevisiae (boulardii) biocodex czy $S$. cerevisiae (boulardii) CNCM I-745. Występują one w postaci doustnych leków przeciwbiegunkowych z grupy 
probiotyków. W jelitach wykazują działanie o charakterze przeciwzapalnym i przeciwdrobnoustrojowym. Przykładem jest S. cerevisiae (boulardii) CNCM I-745 występujący w preparacie Enterol, który cechuje się aktywnością przeciwzapalną wobec enterokrwotocznego szczepu E. coli oraz przeciwdrobnoustrojową w stosunku do bakterii z gatunków E. coli, C. difficile, S. Typhimurium, Y. enterolitica i grzybów drożdżoidalnych C. albicans, C. krusei, C. pseudotropicalis. Szczep wykazuje również aktywność neutralizacji toksyn bakteryjnych, takich jak toksyna A-C. difficile i toksyna cholery. Inne działania probiotyku to immunostymulujące wydzielanie przeciwciał klasy IgA i innych immunoglobulin, co zwiększa wydzielanie poliamin (sperminy, spermidyny) oraz zwiększa stężenie sekrecyjnych immunoglobulin IgA. U tego szczepu obserwuje się również aktywność enzymów $\mathrm{z}$ grupy disacharydaz S. cerevisiae (boulardii), wytwarza on także witaminy $\mathrm{z}$ grupy $\mathrm{B}$ : $\left(\mathrm{B}_{1}, \mathrm{~B}_{2}, \mathrm{~B}_{6}\right.$, kwas pantotenowy i nikotynowy).

Tabela 20. Preparaty roślinne hamujące wzrost szczepów bakterii z rodzaju Lactobacillus, Bifidobacterium i Streptococcus [opracowano na podstawie: Hołderna-Kędzia i Kędzia 2012]

\begin{tabular}{|c|c|c|}
\hline $\begin{array}{c}\text { Preparat pochodzenia } \\
\text { roślinnego }\end{array}$ & $\begin{array}{c}\text { Składniki biologiczne } \\
\text { hamujące namnażanie szczepów }\end{array}$ & Szczep probiotyczny \\
\hline Terpichol - kapsułki & $\begin{array}{l}\text { mentol, menton, } \alpha \text {-pinen, cyneol, } \\
\text { kamfen }\end{array}$ & $\begin{array}{l}\text { B. bifidum ATCC } 14485 \text {, } \\
\text { L. acidophilus ATCC } 4356\end{array}$ \\
\hline Alliofil - drażetki & $\begin{array}{l}\text { czosnek suszony, sproszkowany liść } \\
\text { pokrzywy }\end{array}$ & $\begin{array}{l}\text { S. salivarius ssp. thermophilus } \\
\text { ATCC } 14485, \text { L. acidophilus } \\
\text { ATCC } 4356\end{array}$ \\
\hline Urosept - drażetki & $\begin{array}{l}\text { wyciąg z korzenia pietruszki, } \\
\text { naowocni fasoli, liści brzozy, } \\
\text { borówki brusznicy, koszyczków } \\
\text { rumianku }\end{array}$ & L. acidophilus ATCC 4356 \\
\hline Alax - drażetki & $\begin{array}{l}\text { alona - zagęszczony sok z liści } \\
\text { aloesu, wyciąg z kory kruszyny }\end{array}$ & L. acidophilus ATCC 4356 \\
\hline $\begin{array}{l}\text { Nursea trawienie - } \\
\text { tabletki }\end{array}$ & $\begin{array}{l}\text { wyciąg z kłącza ostryża długiego } \\
\text { i ziela karczocha }\end{array}$ & $\begin{array}{l}\text { B. bifidum ATCC } 14485 \text {, } \\
\text { L. acidophilus ATCC } 4356\end{array}$ \\
\hline Tinctura Salviae - płyn & wyciąg z liści szałwii & $\begin{array}{l}\text { L. casei ATCC } 393 \text {, } \\
\text { L. rhamnosus Hansen } 1968 \text {, } \\
\text { S. salivarius ssp. thermophilus } \\
\text { ATCC } 14485, \text { B. bifidum ATCC } \\
14485 \text {, L. acidophilus ATCC } \\
4356\end{array}$ \\
\hline Pectosol - krople & $\begin{array}{l}\text { wyciąg z korzeni omanu wielkiego } \\
\text { i mydlnicy, porostu islandzkiego, } \\
\text { ziela hyzopu i macierzanki }\end{array}$ & $\begin{array}{l}\text { L. acidophilus ATCC } 4356 \text {, } \\
\text { L. casei ATCC } 393 \text {, } \\
\text { L. rhamnosus Hansen } 1968 \text {, } \\
\text { B. bifidum ATCC } 14485\end{array}$ \\
\hline $\begin{array}{l}\text { Uroval manosa - } \\
\text { kapsułki }\end{array}$ & wyciąg z żurawiny wielkoowocowej & $\begin{array}{l}\text { B. bifidum ATCC } 14485 \text {, } \\
\text { L. acidophilus ATCC } 4356\end{array}$ \\
\hline
\end{tabular}


Tabela 21. Preparaty roślinne obojętne $(0)$, hamujące $(-)$ lub aktywujące $(+)$ wzrost szczepu drożdży probiotycznych $S$. cerevisiae (boulardii) SB48-MYA-796 [opracowano na podstawie: Hołderna-Kędzia i Kędzia 2012]

\begin{tabular}{|c|c|c|}
\hline $\begin{array}{l}\text { Preparat pochodzenia } \\
\text { roślinnego }\end{array}$ & $\begin{array}{c}\text { Skladniki } \\
\text { biologicznie aktywne }\end{array}$ & $\begin{array}{c}\text { Dzialanie preparatu na szczep } \\
\text { S. cerevisiae (boulardii) } \\
\text { SB48-MYA-796 }\end{array}$ \\
\hline Terpichol - kapsułki & $\begin{array}{l}\text { mentol, menton, } \alpha \text {-pinen, cyneol, } \\
\text { kamfen }\end{array}$ & 0 \\
\hline Urosept - drażetki & $\begin{array}{l}\text { wyciąg z korzenia pietruszki, } \\
\text { naowocni fasoli, liści brzozy, } \\
\text { borówki brusznicy, koszyczków } \\
\text { rumianku }\end{array}$ & 0 \\
\hline $\begin{array}{l}\text { Uroval manosa - } \\
\text { kapsułki }\end{array}$ & $\begin{array}{l}\text { wyciąg z żurawiny } \\
\text { wielkoowocowej }\end{array}$ & 0 \\
\hline Alliofil - drażetki & $\begin{array}{l}\text { czosnek suszony, sproszkowany } \\
\text { liść pokrzywy }\end{array}$ & - \\
\hline Tinctura Salviae - płyn & wyciąg z liści szałwii & - \\
\hline Alax - drażetki & $\begin{array}{l}\text { alona - zagęszczony sok z liści } \\
\text { aloesu, wyciąg z kory kruszyny }\end{array}$ & $?$ \\
\hline Pectosol - krople & $\begin{array}{l}\text { wyciąg z korzeni omanu wielkiego } \\
\text { i mydlnicy, porostu islandzkiego, } \\
\text { ziela hyzopu i macierzanki }\end{array}$ & - \\
\hline Alax - drażetki & $\begin{array}{l}\text { alona - zagęszczony sok z liści } \\
\text { aloesu, wyciąg z kory kruszyny }\end{array}$ & + \\
\hline $\begin{array}{l}\text { Nursea trawienie - } \\
\text { tabletki }\end{array}$ & $\begin{array}{l}\text { wyciąg z kłącza ostryża długiego } \\
\text { i ziela karczocha }\end{array}$ & + \\
\hline
\end{tabular}

Badania kliniczne wykazują, że zastosowanie szczepu S. cerevisiae (boulardii) skraca czas trwania ostrych biegunek infekcyjnych u dzieci o około jeden dzień [Nowak i in. 2010]. Potwierdzają to badania Kotowskiej i współpracowników, w czasie których podawano doustnie probiotyk z S. cerevisiae (boulardii) w dawce $250 \mathrm{mg}$ dwa razy dziennie, gdzie obserwowano rzadsze występowanie biegunek u 7,5\% dzieci niż w grupie placebo, w której biegunki pojawiły się u $23 \%$ dzieci. Równocześnie nie obserwowano negatywnych efektów działania tej terapii [Kotowska i in. 2005]. S. cerevisiae (boulardii) jest też skuteczny w leczeniu biegunek poantybiotykowych spowodowanych działaniem $C$. difficile u dzieci oraz osób dorosłych. Polecana dawka probiotyku wynosi $2,5 \cdot 10^{10} \mathrm{j}$. na dzień przez okres 6 tygodni, zaś w biegunkach o zaostrzonym przebiegu zaleca się dawkę $1,2 \cdot 10^{10}$ j. na dzień przez 5 dni [Steinka 2011, Salazar-Lindo i in. 2004]. Ponadto efektyw- 
ność działania szczepu obserwowano u 71\% pacjentów z remisją wrzodziejącego zapalenia jelita grubego (colitis ulcerosa) [Guslandi 2003].

Sprawdzono wpływ preparatów roślinnych na aktywność szczepu S. cerevisiae (boulardii) SB48-MYA-796 [Hołderna-Kędzia i Kędzia 2012]. Ma to znaczenie w przypadku, kiedy pacjent oprócz probiotyku stosuje inny lek pochodzenia roślinnego. Ważne jest sprawdzienie, czy między nimi nie dochodzi do interakcji i czy nie ma przeciwskazań do ich równoczesnego stosowania (tab. 21).

Analiza otrzymanych wyników pokazuje, że preparaty roślinne wykazują zróżnicowaną aktywność wobec drożdży probiotycznych $S$. cerevisiae (boulardii) SB48-MYA-796. Z pewnością nie należy ich stosować wspólnie z preparatami hamującymi namnażanie drożdży. Jednak ciekawe wydaje się przeprowadzenie dalszych badań w kierunku oznaczenia pojedynczych substancji, które bezpośrednio hamują namnażanie tych mikroorganizmów, gdyż farmaceutyczne preparaty roślinne są zwykle mieszaniną wielu związków bioaktywnych. 


\section{Zastosowanie ekstraktów roślinnych w ochronie roślin przed chorobotwórczymi grzybami i bakteriami}

Ekstrakty roślinne mają zastosowanie w ochronie roślin uprawnych i ozdobnych przed patogenami pochodzenia grzybowego i bakteryjnego. Badania nad biologicznymi środkami ochrony roślin w krajach Unii Europejskiej w ostatnich latach bardzo zyskały na znaczeniu. Wynika to z wymagań stawianych rolnictwu ekologicznemu i zintegrowanemu ujętych w Dyrektywie Parlamentu Europejskiego i Rady 2009/128/WE z 21 października 2009 r., ustanawiającej ramy wspólnotowego działania na rzecz zrównoważonego stosowania pestycydów [Dz. Urz. UE L 309/71 z 24.11.2009, art. 14, załącznik nr III], które całkowicie lub częściowo eliminują powszechne, chemiczne środki ochrony roślin. W Polsce uprawy organiczne rozwijały się prężenie od końca lat 90. XX w. i w 2015 r. stanowiły 674694 ha. Natomiast w całej Unii Europejskiej w 2016 r. było to $12 \mathrm{mln}$ ha [Pylak i in. 2019]. Również w innych regionach świata (np. w Azji) obserwuje się wzmożone zainteresowanie użyciem naturalnych preparatów do ochrony roślin uprawnych zamiast pestycydów, co wynika z obserwacji danych dostępnych w literaturze z ostatnich lat. Wzrastająca świadomość konsumentów dotycząca zdrowej żywności także pozytywnie wpływa na rozwój badań i komercjalizację naturalnych preparatów roślinnych.

Ekstrakty roślinne są ekologicznie przyjazne i biodegradowalne, często również są tańsze niż konwencjonalne pestycydy. Poprawiają produkcję rolniczą poprzez zwiększenie potencjału antyoksydacyjnego, wyzwalanie mechanizmów odporności systemicznej roślin na choroby, wzmacnianie poboru wody i składników odżywczych i zwiększenie fotosyntezy u roślin uprawnych [Ganie i in. 2013]. Jednym z najważniejszych etapów w przygotowaniu ekstraktu jest wybór odpowiedniego materiału roślinnego i metody ekstrakcji. Wybór właściwego rozpuszczalnika decyduje o ekstrakcji największej ilości substancji aktywnej, więc istotna jest standaryzacja warunków ekstrakcji [Gurjar i in. 2012, Pylak 
i in. 2019]. Gatunki roślin wybierane do badań zależą zwykle od dostępności $\mathrm{w}$ danym regionie świata, od prowadzonych tam upraw oraz lokalizacji ośrodków zajmujących się badaniem właściwości różnych części roślin i opracowywaniem nowych, naturalnych preparatów ochronnych. Do popularnych ekstraktów roślinnych, które można zastosować do produkcji biopreparatów wykorzystywanych w zapobieganiu chorobom roślin i zwalczaniu ich, należą m.in. ekstrakty $\mathrm{z}$ miodli indyjskiej (Azadirachta indica A. Juss), czosnku (Allium sativum Linn.), eukaliptusa (Eucalyptus globulus), ostryża długiego (kurkumy - Curcuma longa Linn.) oraz imbiru (Zingiber officinale Rosc.) i tytoniu (Nicotiana tabacum Linn.). Natomiast popularne olejki eteryczne wykorzystywane w ochronie roślin to: olejek pokrzywowy (Urtica spp.), tymiankowy (Thymus vulgaris Linn.), eukaliptusowy, rutowy (Ruta graveolens Linn.), herbaciany (Melaleuca alternifolia) oraz z trawy cytrynowej (Cymbopogon flexuosus Wats.) [Gurjar i in. 2012].

Pomimo wielu niewątpliwych zalet, preparaty roślinne mają ograniczenia, do których należą: trudności w standaryzacji metod ekstrakcji, szybka degradacja, dobra skuteczność w badaniach in vitro, a ograniczona w stosowaniu polowym, potrzeba tworzenia formuł użytkowych preparatów, szkodliwość niektórych składników roślinnych dla ludzi i roślin [Gurjar i in. 2012].

Ekstrakty i substancje izolowane z czosnku (Allium sativum) charakteryzują się szerokim spektrum działania na grzyby fitopatogenne takie jak: Fusarium sp., Alternaria sp., Botrytis sp., Phytophtora sp. i inne. Substancją szczególnie działającą biobójczo jest allicyna powstająca $\mathrm{z}$ alliiny po mechanicznym uszkodzeniu tkanek i uwolnieniu enzymu - liazy alliiny [Curtis i in. 2004]. Mechanizm działania allicyny jest oparty na jej aktywności inhibitora syntetazy acetylokoenzymu A i blokowania syntezy kwasów tłuszczowych, steroli i innych. Drugą czynną substancją jest ajoen, który powstaje z allicyny [Saniewska 1996]. Na rynku są dostępne preparaty na bazie czosnku takie jak Bioczos BR i Bioczos płynny, przeznaczone do ochrony roślin warzywnych i ozdobnych. Badania skuteczności Bioczosu wobec szarej pleśni na uprawie truskawki prowadziły Marjańską-Cichoń i Sapiehę-Waszkiewicz [2011], które stwierdziły podobne działanie preparatu przeciwgrzybowego do rutynowo stosowanego pestycydu Switch 62,5 WG. Ponadto nie wpływał on negatywnie na cechy jakościowe truskawek [Marjańska -Cichoń i Sapieha-Waszkiewicz 2011]. Daniel i in. [2015] potwierdzili działanie hamujące ekstraktów z czosnku, otrzymując w wyniku działania 40-procentowym wodnym roztworem czosnku hamowanie $B$. cinerea w $92 \%$, a roztwory 60- i 80-procentowe wykazały 100\% skuteczności hamującej [Daniel i in. 2015]. Wykazano też efektywne działanie ekstraktu z czosnku oraz allicyny na P. infestans i Alternaria spp. in vitro i w badaniach polowych na marchwi, pomidorach, ziemniakach [Slusarenko i in. 2008]. Ekstrakty wodne z czosnku o stężeniach 1,$25 ; 2,5$ i $5 \%$ w pełni hamowały in vitro wzrost grzybni patogenu $L$. theobromae powodującego gnicie końców łodyg drzew owocowych, np. cytrusowych lub pestkowych, natomiast wzrost $L$. pseudotheobromae był ograniczony w $81,17 \%$ działaniem 5-procentowego ekstraktu [Bui i in. 2018]. 
Wyciągi z nasion i miąższu grejpfruta (Citrus paradise) działają grzyboi bakteriobójczo, a ponadto wzmacniają system odporności roślin. Wśród wielu związków antygrzybowych występujących w wyciągu z grejpfruta dominują alifatyczne aldehydy, monoterpeny (limonem) i nutkaton, które mogą działać synergistycznie w hamowaniu wzrostu i rozwoju fitopatogenów [Kurzawińska 2016]. Stwierdzono, że wyciąg z grejpfruta redukuje liczbę grzybów patogennych: $F$. oxysporum, A. alternata, $B$. cinerea rozwijających się na grochu lub fasoli [Patkowska 2006]. Może też być stosowany in vitro do hamowania kiełkowania zarodników B. cinerea - wykiełkowało tylko 14\% zarodników na winogronach, po spryskaniu tylko 17,2\% owoców posiadało objawy infekcji [Xu i in. 2007]. $\mathrm{Na}$ rynku są dostępne wyciągi z grejpfruta pod nazwą Biosept Active (dawniej Biosept 33SL) i Septovital 200 SL (dawniej Grevit 200 SL) zalecane do ochrony roślin przed zgorzelą siewek, fuzariozą, fytoftorozą, mączniakami, rdzami i innymi chorobami grzybowymi.

Wodne i wodno-acetonowe wyciągi z roślin z rodziny baldaszkowatych: kopru ogrodowego (Antheum graveolens), pasternaku (Pastinacia sativa), pietruszki (Petroselium hortens v. crispum) istotnie hamują wzrost kolonii następujących grzybów: $R$. solani, F. solani, B. cinerea dzięki działaniu kumaryny i furanokumaryny. Ekstrakt z pietruszki działa fungistatycznie na $S$. nodorum - patogen pszenicy, podobnie jak metanolowe wyciągi z pietruszki i kopru [Moliszewska i Burgieł 1998]. Również wyciąg z ziela barszczu Sosnowskiego (Heracleum sosnowskyi) okazał się działać hamująco w $90 \%$ na kiełkowanie zarodników F. culmorum, zaś słabiej na B. cinerea [Piotrowski i in. 1995].

Kolejną rośliną, której ekstrakty wykorzystuje się do hamowania wzrostu grzybów chorobotwórczych jest koper włoski (Foeniculum vulgare) należący do rodziny selerowatych (Apiaceae), występujący na południu Europy, zwłaszcza w rejonie śródziemnomorskim oraz w wielu rejonach tropikalnych na świecie [Khan 2017]. Wykazano, że ekstrakty z nasion i skórki hamują kiełkowanie zarodników S. sclerotiorum [Soylu i in. 2007]. Ekstrakty wodne działają hamująco na wzrost A. alternata w metodzie krążkowo-dyfuzyjnej. Za działanie ekstraktów z nasion odpowiadają obecne w nich flawonoidy, fenole, aglikony, glikozydy, pochodne kwasu hydroksycynamonowego i anetol. Efekt toksyczności oparty jest na inhibicji białek poprzez oksydację grup sulfhydrylowych lub poprzez interakcje niespecyficzne. Metanolowe ekstrakty nie wykazywały istotnego działania na grzyby, co tłumaczy się spadkiem rozpuszczalności i lotności składników chemicznych podczas ekstrakcji rozpuszczalnikiem organicznym [Khan 2017].

Obiecujące wyniki dotyczące hamującego wpływu różnych ekstraktów z korzeni i kłączy bergenii (Bergenia stracheyi) na grzyby fitopatogenne uzyskali Kumar i Tyagi [2013]. Stosowali oni ekstrakty etanolowe, octanowe, chloroformowe, eterowe na: A. alternata, $C$. gloeosporioides, F. oxysporium i $R$. solani. Etanolowy ekstrakt w stężeniu 3,5\% hamował in vitro całkowicie wzrost grzybni Alternaria i Rhizoctonia, w $87 \%$ hamował wzrost Colletotrichum i w 79\% Fusarium. Działanie pozostałych rodzajów ekstraktów było znacznie słabsze. Za właściwości 
przeciwdrobnoustrojowe bergenii odpowiadają bergenina, arbutyna, hydrochinon, $\beta$-sitosterol, arbutyna metylu. Jednak ekstrakty mogą działać toksycznie, więc ich zastosowanie jest mimo wszystko ograniczone w praktyce [Kumar i Tyagi 2013].

Działanie pięciu etanolowych ekstraktów roślinnych uzyskanych z bylicy piołunu (Artemisia absinthium L.), datury (Datura stramonium L.), pokrzywy zwyczajnej (Urtica dioica L.), orzecha włoskiego (Juglans regia L.) i mięty polnej (Mentha arvensis L.) przebadano in vitro wobec $A$. solani. Wszystkie ekstrakty działały przeciwgrzybowo. Ekstrakt z $D$. stramonium był najskuteczniejszy w hamowaniu wzrostu patogenu, wykazał średnią inhibicję wzrostu $A$. solani w $61,12 \%$. Drugi pod tym względem był ekstrakt z A. absinthium w 58,54\%. Najmniej skuteczny okazał się ekstrakt z pokrzywy, który ograniczał grzybnię średnio w 37,34\%. Pod względem stężenia ekstraktów najskuteczniejsze były roztwory 60-procentowe, dając średni stopień inhibicji patogenu w 57,37\%, natomiast roztwór ekstraktu z datury hamował mycelium nawet w 71,57\%. Z drugiej strony, spośród roztworów 20-procentowych ekstrakty $z$ datury i bylicy hamowały patogen $w$ ponad 50\% [Ganie i in. 2013].

Do hamowania $S$. rolfsii - patogenu glebowego, powodującego choroby ponad 500 gatunków roślin, użyto wodnych ekstraktów z liści rośliny Moringa oleifera (zwanej drzewem chrzanowym). Badania na płytkach Petriego wykazały wysokie działanie hamujące ekstraktów sporządzonych z 15 i 20 g liści w $10 \mathrm{~cm}^{3}$ wody. W doświadczeniach szklarniowych i polowych ekstrakty z 15 i $20 \mathrm{~kg}$ liści na 101 . wody ograniczały w ok. $30 \%$ objawy choroby grochu południowego ( $\mathrm{Vi}$ gna unguiculata): zamieranie siewek i zgniliznę łodyg [Adandonon i in. 2006]. $\mathrm{W}$ innych badaniach sprawdzono przeciwdrobnoustrojowe działanie ekstraktów uzyskanych z kwiatów aksamitki (Tagetes erecta), gailardii (Gaillardia aristata), chryzantemy (Chrysanthemum indicum) i mleczary (Calotropis gigantea) na S. rolfsii. Wykazano najwyższą skuteczność wodnych ekstraktów zarówno w podłożu płynnym z dodatkami różnych stężeń ekstraktów, jak i na płytkach Petriego. Obserwacje pokazały, że najskuteczniejsze były ekstrakty o stężeniu $100 \mathrm{mg} \cdot \mathrm{cm}^{-3}$ z kwiatów aksamitki, następnie mleczary i chryzantemy, dając strefy inhibicji odpowiednio $19,7 \mathrm{~mm}, 18,3 \mathrm{~mm}$ i $18,0 \mathrm{~mm}$. Badania in vivo na ciecierzycy wykazały, że ekstrakty z kwiatów aksamitki hamowały kiełkowanie zarodników patogenu w ok. 30\% i ograniczały wystąpienie objawów gnicia w ok. 40-50\%, w zależności od użytych stężeń [Wavare i in. 2017].

Badano również działanie ekstraktów roślinnych na ograniczanie wzrostu bakterii z rodzaju Xanthomonas powodujących choroby roślin uprawnych na całym świecie. Bakterie te infekują 124 gatunki roślin jednoliściennych i 268 gatunków roślin dwuliściennych, dając m.in. objawy zarazy bakteryjnej ryżu, czarnej zgnilizny kapusty i zarazy cytrusowej. Deivamani i Muthamilan [2015] sprawdzali wpływ wodnych ekstraktów z roślin: Abutilon indicum L., Acalypha indica L., Aegle marmelos L., Azadirachta indica A., Calotropis gigantea L., Coleus forskohlii, Datura stramonium L., Neerium oleander L., Ocimum basilicum L., Ocimum sanctum L., Parthenium hysterophorus L., Phyllanthus niruri L., Polyalthia longifolia L., 
Prosopis juliflora L. i Vitex negundo L. na izolaty $X$. campestris pv. campestris $\mathrm{z}$ kapusty. Badacze zaobserwowali w metodzie in vitro najlepsze działanie hamujące wzrost bakterii 10-procentowych ekstraktów z datury Datura stramonium L., Phyllanthus niruri L. i Polyalthia longifolia L. [Deivamani i Muthamilan 2015]. Xanthomonas axonopodis pv. citri jest bakterią powodującą zmiany martwicze na różnych częściach roślin cytrusowych. Tahir i in. [2016] przetestowali, jak działa na nią 10 wodnych ekstraktów z różnych części następujących roślin: czosnku (Allium sativum L.), cebuli (Allium cepa L.), miodli indyjskiej (Azadirachta indica), chilli (Capsicum annum), Calotropis gigantea, Dalbrgia sissoo, eukaliptusa (Eucalyptus camelduensis), gardenii (Gardenia florida), melii pospolitej (Melia azedarach) oraz imbiru (Zingiber officinalis), stosując metodę studzienkową. Najskuteczniejsze było antybakteryjne działanie czosnku i miodli indyjskiej, chociaż w metodzie in vivo ekstrakty te samodzielnie w niewielkim stopniu ograniczały występowanie zmian chorobowych na roślinach cytrusowych [Tahir i in. 2016].

Olejki eteryczne pozyskiwane z roślin są mieszaninami lotnych związków organicznych, zawierającymi składniki utlenione i węglowodory: seskwiterpeny i monoterpeny. Składniki te odpowiadają za właściwości przeciwdrobnoustrojowe olejków, a mechanizm ich działania związany jest z ich naturą lipofilową, dzięki której mogą wchodzić w reakcje z błonami komórkowymi grzybów (wiązanie ergosteroli, inhibicja biosyntezy błony), powodując destrukcję błony i wyciek składników komórkowych. Ponadto olejki powodują utratę energii przez komórki na skutek hamowania łańcucha oddechowego w błonach mitochondrialnych, inhibicji pomp protonowych i spadku produkcji ATP [Nazzaro $\mathrm{i}$ in. 2017, Tomazoni i in. 2017]. Wykazano również działanie inhibicyjne na polimeryzację chityny, co ma wpływ na dojrzewanie ściany komórkowej grzybów, tworzenie sept, zakłócenia podziału komórkowego i wzrostu komórek [Nazzaro i in. 2017]. Wyczerpujące informacje dotyczące mechanizmów działania olejków eterycznych i ich głównych składników wraz z przykładami znajdują się w opracowaniu Nazzaro i in. [2017]. Olejki eteryczne otrzymywane z wielu roślin działają hamująco na rozmnażanie i rozwój mikroorganizmów chorobotwórczych dla roślin, wykazują działanie biobójcze przede wszystkim przy zwalczaniu grzybów: Penicillium sp., Alternaria sp., F. oxysporum, P. cryptogea, S. vesicarium, S. fuliginea, wykazują także właściwości zapobiegania kiełkowaniu zarodników i grzybni [Ciesielska i in. 2011]. Spośród olejków eterycznych na uwagę zasługują: olejek miętowy, tymiankowy i kminkowy, które hamowały w badaniach in vitro wzrost grzybów Pytium sp. i F. sulphurenum oraz olejki: eukaliptusowy, rozmarynowy, lawendowy hamujące Fusarium spp. i inne grzyby [Bartyńska i Budzikur-Ramza 2001]. Olejek miętowy uzyskuje się z liści i kwitnących wierzchołków Mentha piperita L. W jego składzie występują: mentol, menton, różne estry, pinen, tymol, karwon, aldehyd octowy i izowalerianowy, octan i izowalerianian metylu oraz substancje taninowe i żywiczne [Ciesielska i in. 2011]. Olejek kminkowy jest lotnym olejem roślinnym uzyskiwanym z Carum carvi L., rośliny z rodziny baldaszkowatych występującej w Europie i Azji środkowej i zachodniej, obecnie uprawianej w Wielkiej Brytanii, Rosji i Ameryce. W skład olejku kminkowego wchodzi karwon (53-63\%) oraz $d$-limonen [Ciesielska i in. 2011]. 
Tabela 22. Wykaz najbardziej znanych patogenów grzybowych roślin i preparatów produkowanych $\mathrm{z}$ roślin, których działanie przeciwdrobnoustrojowe zostało przebadane

\begin{tabular}{|c|c|c|c|c|}
\hline Patogen & Roślina & Preparat & Metoda & Źródło \\
\hline $\begin{array}{l}\text { Alternaria } \mathrm{sp} . \\
\text { A. alternata } \\
\text { A. alternata } \\
\text { A. solani } \\
\end{array}$ & $\begin{array}{l}\text { czosnek } \\
\text { grejpfrut } \\
\text { koper włoski } \\
\text { bergenia } \\
\text { bylica piołun, } \\
\text { datura, } \\
\text { pokrzywa zw., } \\
\text { orzech włoski } \\
\text { mięta polna, } \\
\text { eukaliptus, } \\
\text { kamforowiec }\end{array}$ & $\begin{array}{l}\text { ekstrakt, allicyna } \\
\text { ekstrakt } \\
\text { ekstrakt } \\
\text { ekstrakt } \\
\text { ekstrakt } \\
\text { ekstrakt } \\
\text { ekstrakt } \\
\text { ekstrakt } \\
\text { ekstrakt } \\
\text { olejki eteryczne }\end{array}$ & $\begin{array}{l}\text { in vitro, polowa } \\
\text { in vivo } \\
\text { in vitro } \\
\text { in vitro } \\
\text { in vitro } \\
\text { in vitro } \\
\text { in vitro } \\
\text { in vitro } \\
\text { in vitro } \\
\text { in vitro, in vivo }\end{array}$ & $\begin{array}{l}\text { Slusarenko i in. } 2008 \\
\text { Patkowska } 2006 \\
\text { Khan } 2017 \\
\text { Kumar i Tyagi } 2013 \\
\text { Ganie i in. } 2013 \\
\text { Ganie i in. } 2013 \\
\text { Ganie i in. } 2013 \\
\text { Ganie i in. } 2013 \\
\text { Ganie i in. } 2013 \\
\text { Tomazoni i in. } 2017\end{array}$ \\
\hline A. oryzae & $\begin{array}{l}\text { oleander, } \\
\text { Pithecolobium } \\
\text { dulce }\end{array}$ & olejki eteryczne & & Harish i in. 2008 \\
\hline $\begin{array}{l}\text { B. cinerea } \\
\text { B. cinerea } \\
\text { B. cinerea } \\
\text { B. cinerea } \\
\text { B. cinerea }\end{array}$ & \begin{tabular}{|l|} 
czosnek \\
\\
czosnek \\
grejpfrut \\
grejpfrut \\
pietruszka, \\
koper ogrodowy, \\
pasternak
\end{tabular} & $\begin{array}{l}\text { ekstrakt } \\
\\
\text { ekstrakt } \\
\text { ekstrakt } \\
\text { ekstrakt } \\
\text { ekstrakty }\end{array}$ & \begin{tabular}{|l} 
polowa \\
in vivo \\
in vitro, in vivo
\end{tabular} & $\begin{array}{l}\text { Marjańska-Cichoń } \\
\text { i Sapieha- } \\
\text {-Waszkiewicz } 2011 \\
\text { Daniel i in. } 2015 \\
\text { Patkowska } 2006 \\
\text { Xu i in. 2007 } \\
\text { Moliszewska i Burgieł } \\
1998\end{array}$ \\
\hline C. gloeosporioides & bergenia & ekstrakty & in vitro & Kumar i Tyagi 2013 \\
\hline $\begin{array}{l}\text { F. culmorum } \\
\text { F. oxysporum } \\
\text { F. oxysporum } \\
\text { F. solani } \\
\text { F. sulphurenum } \\
\text { Fusarium spp. } \\
\text { F. poae }\end{array}$ & \begin{tabular}{|l|} 
barszcz \\
sosnowskiego \\
grejpfrut \\
bergenia \\
pietruszka, \\
koper ogrodowy, \\
pasternak \\
mięta, tymianek, \\
koper \\
eukaliptus, \\
rozmaryn, \\
lawenda \\
lawenda, melisa
\end{tabular} & \begin{tabular}{|l|} 
ekstrakt \\
ekstrakt \\
ekstrakt \\
ekstrakty \\
olejki eteryczne \\
olejki eteryczne \\
ekstrakty, olejki \\
eteryczne
\end{tabular} & $\begin{array}{l}\text { in vivo } \\
\text { in vitro } \\
\text { in vitro } \\
\text { in vitro } \\
\text { in vitro }\end{array}$ & $\begin{array}{l}\text { Piotrowski i in. } 1995 \\
\text { Patkowska } 2006 \\
\text { Kumar i Tyagi } 2013 \\
\text { Moliszewska i Burgieł } \\
1998 \\
\\
\text { Bartyńska i Budzikur- } \\
\text {-Ramza } 2001 \\
\text { Bartyńska i Budzikur- } \\
\text {-Ramza 2001 } \\
\\
\text { Czerwińska i Szparaga } \\
\text { 2015 }\end{array}$ \\
\hline $\begin{array}{l}\text { L. theobromae } \\
\text { L. pseudotheobromae }\end{array}$ & czosnek & ekstrakty & in vitro & Bui $i$ in. 2018 \\
\hline \begin{tabular}{|l} 
P. infestans \\
P. nicotianae \\
P. capsicum
\end{tabular} & $\begin{array}{l}\text { czosnek } \\
\text { lilak wczesny } \\
\text { trawa } \\
\text { cytrynowa, } \\
\text { bazylia }\end{array}$ & $\begin{array}{l}\text { ekstrakt, allicyna } \\
\text { olejek eteryczny } \\
\text { olejki eteryczne }\end{array}$ & $\begin{array}{l}\text { in vitro, polowa } \\
\text { in vitro, in vivo }\end{array}$ & $\begin{array}{l}\text { Slusarenko i in. } 2008 \\
\text { Jing i in. } 2017 \\
\text { Amini i in. } 2016\end{array}$ \\
\hline
\end{tabular}




\begin{tabular}{|c|c|c|c|c|}
\hline $\begin{array}{l}\text { P. drechslei } \\
\text { P. melonis }\end{array}$ & $\begin{array}{l}\text { trawa } \\
\text { cytrynowa, } \\
\text { bazylia } \\
\text { trawa } \\
\text { cytrynowa, } \\
\text { bazylia }\end{array}$ & $\begin{array}{l}\text { olejki eteryczne } \\
\text { olejki eteryczne }\end{array}$ & & $\begin{array}{l}\text { Amini i in. } 2016 \\
\text { Amini i in. } 2016\end{array}$ \\
\hline Pytium sp. & $\begin{array}{l}\text { mięta, tymianek, } \\
\text { koper }\end{array}$ & olejki eteryczne & in vitro & $\begin{array}{l}\text { Bartyńska i Budzikur- } \\
\text {-Ramza } 2001\end{array}$ \\
\hline $\begin{array}{l}\text { R. solani } \\
\text { R. solani }\end{array}$ & $\begin{array}{l}\text { pietruszka, } \\
\text { koper ogrodowy, } \\
\text { pasternak } \\
\text { bergenia }\end{array}$ & $\begin{array}{l}\text { ekstrakty } \\
\text { ekstrakty }\end{array}$ & $\begin{array}{l}\text { in vitro } \\
\text { in vitro }\end{array}$ & $\begin{array}{l}\text { Moliszewska i Burgieł } \\
1998 \\
\text { Kumar i Tyagi } 2013\end{array}$ \\
\hline $\begin{array}{l}\text { S. sclerotiorum } \\
\text { S. sclerotiorum } \\
\text { S. sclerotiorum }\end{array}$ & $\begin{array}{l}\text { koper włoski } \\
\text { sosna zwyczajna } \\
\text { lawenda, melisa }\end{array}$ & $\begin{array}{l}\text { ekstrakt } \\
\text { ekstrakt } \\
\text { ekstrakty, olejki } \\
\text { eteryczne }\end{array}$ & $\begin{array}{l}\text { in vitro } \\
\text { in vitro } \\
\text { in vitro }\end{array}$ & $\begin{array}{l}\text { Soylu i in. } 2007 \\
\text { Czerwińska i Szparaga } \\
2015 \\
\text { Czerwińska i Szparaga } \\
2015\end{array}$ \\
\hline $\begin{array}{l}\text { S. rolfsii } \\
\text { S. rolfsii }\end{array}$ & $\begin{array}{l}\text { Moringa } \\
\text { oleifera } \\
\text { aksamitka, } \\
\text { chryzantema, } \\
\text { mleczara, } \\
\text { gailardia }\end{array}$ & $\begin{array}{l}\text { ekstrakty } \\
\text { ekstrakty } \\
\text { ekstrakty } \\
\text { ekstrakty } \\
\text { ekstrakty }\end{array}$ & $\begin{array}{l}\text { in vitro, in vivo, } \\
\text { polowa } \\
\text { in vitro, in vivo } \\
\text { in vitro } \\
\text { in vitro } \\
\text { in vitro }\end{array}$ & $\begin{array}{l}\text { Adanonon i in. } 2006 \\
\text { Wavare i in. } 2017 \\
\text { Wavare i in. } 2017 \\
\text { Wavare i in. } 2017 \\
\text { Wavare i in. } 2017\end{array}$ \\
\hline S. nodorum & $\begin{array}{l}\text { pietruszka, } \\
\text { koper }\end{array}$ & ekstrakty & in vitro & $\begin{array}{l}\text { Moliszewska i Burgieł } \\
1998\end{array}$ \\
\hline
\end{tabular}

Olejek sosnowy uzyskuje się z odpadów ścieru drzewnego Pinus palustris Mill. i innych gatunków sosen, np. Pinus sylvestris. W jego skład wchodzą przede wszystkim alkohole drugorzędowe i trzeciorzędowe oraz monoterpeny [Ciesielska i in. 2011]. Olejki eteryczne $\mathrm{z}$ igieł sosnowych stosowane są w medycynie ludowej w leczeniu zaburzeń oddechowych. W badaniach Czerwińskiej i Szparagi [2015] wodny wyciąg z sosny zwyczajnej skutecznie hamował wzrost grzyba S. sclerotiorum w metodzie krążkowo-dyfuzyjnej, dając strefę zahamowania wzrostu o średnicy $26,33 \mathrm{~mm}$.

Badania prowadzone nad działaniem roztworów olejków eterycznych ekstrahowanych z roślin eukaliptusa (Eucalyptus globulus i Eucalyptus staigeriana) oraz z kamforowca (Cinnamomum camphora) na patogen pomidorów $A$. solani wykazały dobrą skuteczność in vitro i in vivo. Charakterystyka chromatograficzna wykazała, że głównymi składnikami wyżej wymienionych olejków były odpowiednio: 1,8-cineol, cytral i linalol. Minimalne stężenia hamujące dla poszczególnych olejków wynosiły odpowiednio: $10 \mu \mathrm{l} \cdot \mathrm{cm}^{-3}, 1 \mu \mathrm{l} \cdot \mathrm{cm}^{-3}$ i $1-1,5 \mu 1 \cdot \mathrm{cm}^{-3}$. Najskuteczniej hamowały kiełkowanie zarodników również olejki z Eucalyptus staigeriana i Cinnamomum camphora. Wszystkie olejki były efektywne w kontrolowaniu objawów wczesnej zarazy pomidora, podobnie jak stosowany fungicyd Azoxy- 
strobin, więc mogą być potencjalnie wykorzystane w kontrolowaniu tej choroby pomidora [Tomazoni $\mathrm{i}$ in. 2017].

Rodzina roślin jasnotowatych (Lamiaceae) znana jest ze stosowania jej w kuchni oraz jako czynniki zapobiegające chorobom. Najbardziej znane i wykorzystywane są lawenda (Lavandula angustifolia), melisa (Melissa officinalis), szałwia (Salvia officinalis) oraz paczulka wonna (Pogostemon cablin). Olejki i ekstrakty z tych roślin posiadają właściwości antyseptyczne, przeciwzapalne i przeciwdrobnoustrojowe [Hussain i in. 2011]. Właściwości antygrzybowe wodnych ekstraktów i olejków eterycznych z lawendy i melisy badały Czerwińska i Szparaga [2015] metodą krążkowo-dyfuzyjną. Autorki wykazały największą skuteczność olejków eterycznych na S. sclerotiorum i F. poae, natomiast słabszą na B. cinerea, F. sambucinum i F. solani. [Czerwińska i Szparaga 2015].

Innym ciekawym przykładem rośliny jest lilak wczesny (Syringa oblata), z którego ekstraktów otrzymuje m.in. terpen - eugenol, odpowiedzialny za działanie antygrzybowe. Jing i in. [2017] zastosowali olejek eteryczny z pączków kwiatowych lilaka oraz roztwory eugenolu do hamowania wzrostu grzyba $P$. nicotianae, powodującego chorobę tytoniu, tzw. czarny trzon tytoniowy. Autorzy stwierdzili hamujące działanie eugenolu na badany patogen $\mathrm{z}$ wartością MIC wynoszącą $200 \mu \mathrm{g} \cdot \mathrm{cm}^{-3}$. Eugenol powodował wyciek protoplazmy, wskazując na uszkodzenie błony komórkowej mycelium. Emulsje eugenolu działały ochronnie na tytoń w warunkach testów polowych, co stwarza możliwości praktycznego zastosowania ich w biokontroli P. nicotianae [Jing i in. 2017]. 


\section{Literatura}

Adandonon A., Aveling T.A.S., Labuschagne N., Tamo M., 2006. Biocontrol agents in combination with Moringa oleifera extract for integrated control of Sclerotium-caused cowpea damping-off and stem rot. Europ. J. Plant Pathol. 115, 409-418. DOI: 10.1007/s10658-006-9031-6

Adaszczyńska M., Swarcewicz M., Markowska-Szczupak A., Jadczak D., 2013. Skład chemiczny $i$ wlaściwości przeciwdrobnoustrojowe olejku eterycznego i ekstraktu z mięty pieprzowej odmiana 'ASIA'. Żywn. Nauka Technol. Jakość 2(87), 116-125.

Adaszyńska M., Swarcewicz M., 2013a. Antimicrobial properties of selected secondary plant metabolites and their application in medicine. Med. Biol. Sci. 27(1), 5-11. DOI: 10.12775/ mbs-2013-0001

Adaszyńska M., Swarcewicz M., 2013b. Wybrane wtórne metabolity roślinne jako środki przeciwdrobnoustrojowe. Wiad. Chem. 67(3-4), 303-319.

Adigüzel A., Güllüce M., Şengül M., 2005. Antimicrobial effects of ocimum basilicum (Labiatae) extract. Turk. J. Biol. 29, 155-160.

Alavijeh P.K., Alavijeh P.K., Sharma D., 2012. A study of antimicrobial activity few medicinal herbs. Asian J. Plant Sci. Res. 2, 496-502.

Alfaro M.J., Belanger J.M., Padilla F.C., Pare J.J., 2003. Influence of solvent, matrix dielectric properties, and applied power on the liquid-phase microwave-assisted processes (MAP) extraction of ginger (Zingiber officinale). Food Res. Int. 36(5), 499-504. DOI: 10.1016/S0963-9969(02)00198-9

Alupului A., Calinescu I., Lavric V., 2009. Ultrasonic vs. microwave extraction intensification of active principles from medicinal plants. Chem. Eng. Trans. 17, 1023-1028. DOI: 10.3303/CET0917171

Amini J., Farhang V., Javadi T., Nazemi J., 2016. Antifungal effect of plant essential oils on controlling Phytophthora species. Plant Pathol. J. 32, 16-24. DOI: 10.5423/PPJ.OA.05.2015.0091

Annegowda H.V., Mordi M.N., Ramanathan S., Hamdan M.R., Mansor S.M., 2012. Effect of extraction techniques on phenolic content, antioxidant and antimicrobial activity of Bauhinia purpurea, HPTLC determination of antioxidants. Food Anal. Methods. 5, 226-233. DOI: 10.1007/ s12161-011-9228-y

Ansari M.A., Fatima Z., Hameed S., 2016a. Anticandidal effect and mechanisms of monoterpenoid, perillyl alcohol against Candida albicans. Plos One 11, e0162465. DOI: 10.1371/journal. pone. 0162465

Ansari M.A., Fatima Z., Hameed S., 2016b. Mechanistic insights into the mode of action of anticandidal sesamol. Microb. Pathog. 98, 140-148. DOI: 10.1016/j.micpath.2016.07.004

Arora D.S., Kaur J., 1999. Antimicrobial activity of spices. J. Appl. Bacteriol. 12, 257-262. 
Asan Ozusaglam M., Karakoca K., 2013. Antimicrobial and antioxidant activities of Momordica charanta from Turkey. Afr. J. Biotechnol. 12(13), 1548-1558.

Avci F.G., Sayar N.A., Akbulut B.S., 2018. An OMIC approach to elaborate the antibacterial mechanisms of different alkaloids. Phytochemistry 149, 123-131. DOI: 10.1016/j.phytochem.2017.12.023

Azmir J., Zaidul I.S.M., Rahman M.M., Sharif K.M., Mohamed A., Sahena F., Jahurul M.H.A., Ghafoor K., Norulaini N.A.N., Omar A.K.M., 2013. Techniques for extraction of bioactive compounds from plant materials: A review. J. Food Eng. 117, 426-436. DOI: 10.1016/j.jfoodeng.2013.01.014

Balouiri M., Sadiki M., Ibnsouda S.K., 2016. Methods for in vitro evaluating antimicrobial activity: A review. J. Pharm. Anal. 6, 71-79. DOI: 10.1016/j.jpha.2015.11.005

Baran J., 2008. Nowa epoka cytometrii przeptywowej - przewodnik po wspótczesnych cytometrach i ich zastosowanie. Post. Biol. Kom. 24, 3-15.

Barbieri R., Coppo E., Marchese A., Daglia M., Sobarzo-Sánchez E., Nabavi S.F., Nabavi S.M., 2017. Phytochemicals for human disease: An update on plant-derived compounds antibacterial activity. Microbiol. Res. 196, 44-68. DOI: 10.1016/j.micres.2016.12.003

Barbour E.K., Sharif M.A., Sagherian V.K., Habre A.N., Talhouk R.S., Talhouk S.N., 2004. Screening of selected indigenous plants of Lebanon for antimicrobial activity. J. Ethnopharmacol. 93, 1-7. DOI: $10.1016 /$ j.jep.2004.02.027

Barrajón-Catalán E., Fernández-Arroyo S., Saura D., Guillén E., Fernández-Gutiérrez E., Segura-Carretero E., Micola V., 2010. Cistaceae aqueous extracts containing ellagitannins show antioxidant and antimicrobial capacity, and cytotoxic activity against human cancer cells. Food Chem. Toxicol. 48(8-9), 2273-2282. DOI: 10.1016/j.fct.2010.05.060

Bartyńska M., Budzikur-Ramza E., 2001. The action of some essential oils on fungi. Bull. Pol. Ac. Sci. Biolog. Sci. 49(4), 327-331.

Bassyouni R.H., Wali I.E., Kamel Z., Kassim M.F., 2019. Fennel oil: A promising antifungal agent against biofilm forming fluconazole resistant Candida albicans causing vulvovaginal candidiasis. J. Herbal Med. 15, 100227.

Benelli P., Riehl C.A.S., Smânia A., Smânia E.F.A., Ferreira S.R.S., 2010. Bioactive extracts of orange (Citrus sinensis L. Osbeck) pomace obtained by SFE and low pressure techniques: mathematical modeling and extract composition. J. Supercrit. Fluids 55(1), 132-141. DOI: 10.1016/j.supflu.2010.08.015

Beuria T.K., Santra M.K., Panda D., 2005. Sanguinarine blocks cytokinesis in bacteria byinhibiting Fts Z assembly and bundling. Biochemistry 44, 16584-16593. DOI: 10.1021/bi050767

Bielawska K., Malinowska M., Cyuńczyk M., 2014. Wpływ kumaryn na organizm człowieka. Bromat. Chem. Toksykol. XLVII(2), 213-221.

Bilgin M., Sahin S., 2013. Effects of geographical origin and extraction methods on total phenolic yield of olive tree (Olea europaea) leaves. J. Taiwan Inst. Chem. Eng. 44, 8-12. DOI: 10.1016/j. jtice.2012.08.008

Bluma R.V., Etcheverry M.G., 2008. Application of essential oils in maize grain: Impact on Aspergillus section Flavi growth parameters and aflatoxin accumulation. Food Microbiol. 25, 324-334. DOI: $10.1016 /$ j.fm.2007.10.004

Boeira C.P., Piovesan N., Soquetta M.B., Flores D.C., Lucas B.N., Barin J.S., Rosa C.S., Terra N.N., 2018a. Ultrasonic assisted extraction to obtain bioactive, antioxidant and antimicrobial compounds from marcela. Ciência Rural 48(6). DOI: 10.1590/0103-8478cr20170772

Boeira C.P., Piovesan N., Soquetta M.B., Flores D.C., Lucas B.N., Barin J.S., Rosa C.S., Terra N.N., 2018b. Extraction of bioactive compounds of lemongrass, antioxidant activity and evaluation of antimicrobial activity in fresh chicken sausage. Ciência Rural 48(11). DOI: 10.1590/0103$8478 \mathrm{cr} 20180477$

Borges A., Abreu A.C., Ferreira C., Saavedra M.J., Simões L.C., Simões M., 2015. Antibacterial activity and mode of action of selected glucosinolate hydrolysis products against bacterial pathogens. J. Food Sci. Technol. 52(8), 4737-4748. DOI: 10.1007/s13197-014-1533-1 
Borhan M.Z., Ahmad R., Rusop M., Abdullah S., 2013. Impact of nanopowders on extraction yield of Centella asiatica. Adv. Mater. Res. 667, 246-250. DOI: 10.4028/www.scientific.net/AMR.667.246

Bouarab K., Melton R., Peart J., Baulcombe D., Osbourn A., 2002. A saponin-detoxifying enzyme mediates suppression of plant defences. Nature 418(6900), 889-892. DOI: 10.1038/nature00950

Bouyahya A., Dakka N., Et-Touys A., Abrini J., Bakri Y., 2017. Medicinal plant products targeting quorum sensing for combating bacterial infections. Asian Pac. J. Trop. Med. 10(8), 729-743. DOI: 10.1016/j.apjtm.2017.07.021

Bui R., Sinha B., Devi S., Salam R., Dinesh K., Chakma T., 2018. In vitro studies on efficacy of some plant extracts and biocontrol agents against Lasiodiplodia theobromae and Lasiodiplodia pseudotheobromae. Int. J. Curr. Microbiol. App. Sci. 7(7), 448-457. DOI: 10.20546/ijcmas.2018.707.054

Caputo L., Quintieri L., Cavalluzzi M.M., Lentini L., Habtemariam S., 2018. Antimicrobial and antibiofilm activities of citrus water-extracts obtained by microwave-assisted and conventional methods. Biomedicines 6(2), 70, 1-14. DOI: 10.3390/biomedicines6020070

Carabias-Martinez R., Rodriguez-Gonzalo E., Revilla-Ruiz P., Hernández-Méndez J., 2005. Pressurized liquid extraction in the analysis of food and biological samples. J. Chromatogr. A 1089(1), 1-17. DOI: 10.1016/j.chroma.2005.06.072

Casquete R., Castro M., Martín A., Ruiz-Moyano S., Saraiva J.A., Córdoba M.G., Teixeira P., 2015. Evaluation of the effect of high pressure on total phenolic content, antioxidant and antimicrobial activity of citrus peels. Innov. Food Sci. Emerg. Technol. 31, 37-44. DOI: 10.1177/1082013218768997

Cauchie M., Desmet S., Lagrou K., 2017. Candida and its dual lifestyle as a commensal and a pathogen. Res. Microbiol. 168, 802-810. DOI: 10.1016/j.resmic.2017.02.005

Chan C.-H., Yusoff R., Ngoh G.-C., Kung F., 2011. Microwave-assisted extractions of active ingredients from plants. J. Chromatogr. A. 1218(37), 6213-6225. DOI: 10.1016/j.chroma.2011.07.040

Chandini S.K., Rao L.J., Gowthaman M., Haware D., Subramanian R., 2011. Enzymatic treatment to improve the quality of black tea extracts. Food Chem. 127(3), 1039-1045. DOI: 10.1016/j. foodchem.2011.01.078

Chang W., Zhang M., Li Y., Lou H., 2015. Flow cytometry-based method to detect persisters in Candida albicans. Antimicrob. Agents Chemother. 58, 5044-5048. DOI: 10.1128/AAC.00255-15

Chemat F., Fabiano-Tixier A.S., Vian A.M., Allaf T., Vorobiev E., 2015. Solvent-free extraction of food and natural products. Trends Anal. Chem. 71, 157-168. DOI: 10.1016/j.trac.2015.02.021

Chemat F., Zill-e-Huma, Khan M.K., 2011. Applications of ultrasound in food technology Processing, preservation and extraction. Ultrason. Sonochem. 18, 813-835.

Chen S., Xing X.H., Huang J.J., Xu M.S., 2010. Enzyme-assisted extraction of flavonoids from Ginkgo biloba leaves: improvement effect of flavonol transglycosylation catalyzed by Penicillium decumbens cellulase. Enzyme Microb. Technol. 48(1), 100-105. DOI: 10.1016/j.enzmictec.2010.09.017

Chen S.S., Spiro M., 1994. Study of microwave extraction of essential oil constituents from plant materials. J. Microwave Power E. E. 29, 231-241. DOI: 10.1080/08327823.1994.11688251

Cheynier V., Comte G., Davies K.M., Lattanzio V., Martens S., 2013. Plant phenolics: Recent advances on their biosynthesis, genetics and ecophysiology. Plant Physiol. Biochem. 72, 1-20. DOI: 10.1016/j.plaphy.2013.05.009

Cho J., Choi H., Lee J., Kim M.S., Sohn H.Y., Lee D.G., 2013. The antifungal activity and membrane-disruptive action of dioscin extracted from Dioscorea nipponica. Biochim. Biophys. Acta. 1828, 1153-1158. DOI: 10.1016/j.bbamem.2012.12.010

Choma I., Grzelak E., 2011. Bioautography detection in thin-layer chromatography. J. Chromatogr. A. 1280, 2684-2691. DOI: 10.1016/j.chroma.2010.12.069

Chong Y.M., How K.Y., Yin W.F., Chan K.G., 2018. The effects of chinese herbal medicines on the quorum sensing-regulated virulence in Pseudomonas aeruginosa PAO1. Molecules 23, 972. DOI: $10.3390 /$ molecules 23040972

Chouhan S., Sharma K., Guleria S., 2017. Antimicrobial activity of some essential oils - present status and future perspectives. Medicines 4(3), 58. DOI: 10.3390/medicines4030058

Ciesielska J., Malusa E., Sas Paszt L., 2011. Środki ochrony roślin stosowane w rolnictwie ekologicznym. Skierniewice, s. 11-12. 
Clinical and Laboratory Standards Institute, 2012. Performers standards for antimicrobial disk susceptibility tests, approved standard, 7th ed., CLSI Document M02-A11. Pensylvania, USA.

Conde-Hernández L., Espinosa-Victoria J.R., Trejo A., Guerrero-Beltrán J., 2017. CO _-supercritical extraction, hydrodistillation and steam distillation of essential oil of rosemary (Rosmarinus officinalis). J. Food Engin. 200, 81-86. DOI: 10.1016/j.jfoodeng.2016.12.022

Cosa P., Vlietinck A.J., Berghe D.V., Maes L., 2006. Anti-infective potential of natural products: How to develop a stronger in vitro 'proof-of-concept'. J. Ethnopharmacol. 106, 290-302. DOI: 10.1016/j.jep.2006.04.003

Croaker A., King G.J., Pyne J.H., Anoopkumar-Dukie S., Liu L., 2016. Sanguinaria canadensis. Traditional medicine, phytochemical composition, biological activities and current uses. Int. J. Mol. Sci. 17(9), 1414. DOI: 10.3390/ijms17091414

Curtis H., Noll U., Stormann J., Slusarenko A.J., 2004. Broad-spectrum activity of the volatile phytoanticipins allicin in extracts of garlic (Allium sativum L.) against plant pathogenic bacteria, fungi and Oomycetes. Physiol. Mol. Plant Pathol. 65, 79-89. DOI: 10.1016/j.pmpp.2004.11.006

Cushnie T.P.T., Cushnie B., Lamb A.J., 2014. Alkaloids: an overview of their antibacterial, antibiotic-enhancing and antivirulence activities. Int. J. Antimicrob. Agents 44, 377-386. DOI: 10.1016/j.ijantimicag.2014.06.001

Cushnie T.P.T., Lamb A.J., 2005. Antimicrobial activity of flavonoids. Int. J. Antimicrob. Agents 26, 343-356. DOI: 10.1016/j.ijantimicag.2005.09.002

Czaikoski K., Mesomo M.C., Paula Scheer A. de, Dalla Santa O.R., Queiroga C.L., Corazza M.L., 2015. Kinetics, composition and biological activity of Eupatorium intermedium flower extracts obtained from $\mathrm{ScCO}_{2}$ and compressed propane. J. Supercrit. Fluids 97, 145-153.

Czerwińska E., Szparaga A., 2015. Antibacterial and antifungal activity of plant extracts. Annu. Set Environ. Protect. 17, 209-229.

Dang J., Cui Y., Pei J., Yue H., Liu Z., Wang W., Jiao L., Mei L., Wang Q., Tao Y., Shao Y., 2018. Efficient separation of four antibacterial diterpenes from roots of Salvia pratii using non-aqueous hydrophilic solid-phase extraction followed by preparative high-performance liquid chromatography. Molecules 23, 623. DOI: 10.3390/molecules23030623

Daniel C.K., Lennox C.L., Vries F.A., 2015. In vitro effects of garlic extracts on pathogenic fungi Botrytis cinerea, Penicillium expansum and Neofabraea alba. S. Afr. J. Sci. 111, 1-8. DOI: 10.17159/SAJS.2015/20140240

De Girolamo A., Solfrizzo M., Vitti C., Visconti A., 2004. Occurence of 6-methoxymellein in fresh and processed carrots and relevant effect of storage and processing. J. Agr. Food Chem. 52, 6478-6484. DOI: 10.1021/jf0491660

Dec D., Joka M., Kowalczyk-Sadowy M., 2017. Aktywność przeciwgrzybiczna wybranych ekstraktów roślinnych na szczepy Aspergillusa. Post. Tech. Przetw. Spoż. 1, 15-17.

Deivamani M., Muthamilan M., 2015. Efficacy of biocontrol agents, plant extracts and organic amendments against black rot of cabbage caused by Xanthomonas campestris pv. campestris. J. Innov. Agric. 2(4), 1-9.

Delazar A., Nahar L., Hamedeyazdan S., Sarker S.D., 2012. Microwave-assisted extraction in natural products isolation. Methods Mol. Biol. 864(23), 89-115. DOI: 10.1007/978-1-61779-624-1 5

Dewanjee S., Gangopadhyay M., Bhattabharya N., Khanra R., Dua T.K., 2015. Bioautography and its scope in the field of natural product chemistry. J. Pharm. Anal. 5, 75-84. DOI: 10.1016/j. jpha.2014.06.002

Djeddi S., Bouchenah N., Settar I., Skaltsa H.D., 2007. Composition and antimicrobial activity of the esential oil Rosmarinus officinalis L. from Algieria. Chem. Nat. Compd. 43(4), 487-490. DOI: $10.1007 / \mathrm{s} 10600-007-0172-4$

Duraipandiyan V., Ayyanar M., Ignacimuthu S., 2006. Antimicrobial activity of some ethnomedicinal plants used by Paliyar tribe from Tamil Nadu, India. BMC Complement. Altern. Med. 6, 35. DOI: 10.1186/1472-6882-6-35 Dz. Urz. UE L 309/71 z 24.11.2009. Dyrektywa Parlamentu Europejskiego i Rady 2009/128/WE z dn. 21 października 2009 roku ustanawiająca ramy wspólnotowego działania na rzecz zrównoważonego stosowania pestycydów. 
Elegir G., Kindl A., Sadocco P., Orlandi M., 2008. Development of antimicrobial cellulose packing through laccase-mediated grafting of phenolic compounds. Enzyme Microb. Technol. 43, 84-92. DOI: 10.1016/j.enzmictec.2007.10.003

Eloff J.N., 1998. Which extractant should be used for the screening and isolation of antimicrobial components from plants? J. Ethnopharmacol. 60, 1-8. DOI: 10.1016/s0378-8741(97)00123-2

Elsom G.K., 2000. An antibacterial assay of aqueous extract of garlic against anaerobic/microaerophilic and anaerobic bacteria. Microb. Ecol. Health Dis. 12(2), 81-84. DOI: 10.1080/089106000435464

Ernawita, Wahyuono R.A., Hesse J., Hipler U.-C., Elsner P., Böhm V., 2016. Carotenoids of indigenous citrus species from Aceh and its in vitro antioxidant, antidiabetic and antibacterial activities. Eur. Food Res. Technol. 242, 1869-1881. DOI: 10.1007/s00217-016-2686-0

Eskilsson C.S., Björklund E., 2000. Analytical-scale microwave-assisted extraction. J. Chromatogr. A. 902(1), 227-250. DOI: 10.1016/s0021-9673(00)00921-3

Esper R.H., Gonçalez E., Marques M.O.M., Felicio R.C., Felicio R.D., 2014. Potential of essential oils for protection of grains contaminated by aflatoxin produced by Aspergillus flavus. Frontiers Microbiol. 5, 269. DOI: 10.3389/fmicb.2014.00269

Everette J.D., Bryant Q.M., Green A.M., Abbey Y.A., Wangila G.W., Walker R.B., 2010. Thorough study of reactivity of various compound classes toward the Folin-Ciocalteu reagent. J. Agric. Food Chem. 58(14), 8139-8144.

Farag M.A., Ali S.E., Hodaya R.H., El-Seedi H.R., Sultani H.N., Laub A., Eissa T.F., Abou-Zaid F.O.F., Wessjohann L.A., 2017. Phytochemical profiles and antimicrobial activities of Allium cepa red cv. and A. sativum subjected to different drying methods: a comparative ms-based metabolomics. Molecules 22(5), 761. DOI: 10.3390/molecules22050761

Farnsworth N.R., Akerele O., Bingel A.S., Soejarto D.D., Guo Z., 1985. Medicinal plants in therapy. Bull. World Health Organ. 63, 965-981.

Fischer R., Lautner H., 1961. On the paper chromatographic detection of penicillin preparations. Arch. Pharm. 294, 1-7.

Foo L.W., Salleh E., Mamat S.N., 2015. Extraction and qualitative analysis of piper betle leaves for antimicrobial activities. Int. J. Innov. Res. Sci. Eng. Technol. 2, 1-8.

Ganie S.A., Ghani M.Y., Nissar Q., Rehman S., 2013. Bioefficacy of plant extracts and biocontrol agents against Alternaria solani. Af. J. Microbiol. Res. 7(34), 4397-4402. DOI: 10.5897/ AJMR2013.5901

Gao M., Song B., Lin C., 2006. Dynamic microwave assisted extraction of flavonoids from Maxim. cultured cells. Biochem. Eng. J. 332, 79-83. DOI: 10.1016/j.bej.2006.09.004

Gawęcki J., Libudzisz Z., 2006. Mikroorganizmy w żywności i żywieniu. Wydawnictwo Akademii Rolniczej w Poznaniu, Poznań, 31-40.

Gawlik-Dziki U., 2004. Fenolokwasy jako bioaktywne składniki żywności. Żywn. Nauka. Technol. Jakość. 4(41), 29-40.

Gedikoğlu A., Sökmen M., Çivit A., 2019. Evaluation of Thymus vulgaris and Thymbra spicata essential oils and plant extracts for chemical composition, antioxidant, and antimicrobial properties. Food Sci. Nutr. 7(5), 1704-1714. DOI: 10.1002/fsn3.1007

Gemeda N., Woldeamanuel Y., Asrat D., Debella A., 2014. Effect of essential oils on Aspergillus spore germination, growth and mycotoxin production: a potential source of botanical food preservative. Asian Pac. J. Trop. Biomed. 4, 373-381. DOI: 10.12980/APJTB.4.2014C857

Gião M., Pereira C., Fonseca S., Pintado M., Malcata X., 2009. Effect of particle size upon the extent of extraction of antioxidant power from the plants Agrimonia eupatoria, Salvia sp. and Satureja montana. Food Chem. 117(3), 412-416. DOI: 10.1016/j.foodchem.2009.04.020

Giongo J.L., Voucher R.D.A., Borin D., Correa M.S., Dos Santos V.B., Santos R.C., Boligon A.A., Athayde M., Bonez P.C., Rossi G.G., De Campus M.M.A., Gomes P., Steppe M., 2015. Antimycobacterial, antimicrobial and antifungal activities of geranium oil loaded nanocapsules. Int. J. Pharm. Pharm. Sci. 7, 414-419. https://innovareacademics.org/journals/index.php/ijpps/ article/view/5971 
Giongo J.L., Almeida Voucher R. de, Fausto V.P., Quatrin P.M., Soares Lopes L.Q., Santos R.C.V., Gundel A., Gomes P., Steppe M., 2016. Anti-Candida activity assessment of Pelargonium graveolens oil free and nanoemulsion in biofilm formation in hospital medical supplies. Microbial Pathog. 100, 170-178. DOI: 10.1016/j.micpath.2016.08.013

Gómez-García R., Martínez-Ávila G.C., Aguilar C.N., 2012. Enzyme-assisted extraction of antioxidative phenolics from grape (Vitis vinifera L.) residues. 3 Biotech. 2, 297-300. DOI: 10.1007/ s13205-012-0055-7

Gomez-Lopez A., Aberkane A., Petrikkou E., Mellado E., Rodriguez-Tudela J.L., Cuenca-Estrella M., 2005. Analysis of the influence of Tween concentration, inoculum size, assay medium, and reading time on susceptibility testing of Aspergillus spp. J. Clin. Microbiol. 43, 1251-1255. DOI: 10.1128/JCM.43.3.1251-1255.2005

Gonelimali F.D., Lin J., Miao W., 2018. Antimicrobial properties and mechanism of action of some plant extracts against food pathogens and spoilage microorganisms. Front Microbiol. 9, 1639. DOI: $10.3389 /$ fmicb.2018.01639

González-Lamothe R., Mitchell G., Gatusso M., Diarra M.S., Malouin F., Bouarab K., 2009. Plant antimicrobial agents and their effects on plant and human pathogens. Int. J. Mol. Sci. 10, 3400-3419. DOI: 10.3390/ijms10083400

Grayer R.J., Kokubun T., 2001. The search for phytoalexins and other antifungal compounds from higher plants. Phytochemistry 56, 253-263. DOI: 10.1016/s0031-9422(00)00450-7

Gumusay O.A., Borazan A.A., Ercal N., Demirkol O., 2015. Drying effects on the antioxidant properties of tomatoes and ginger. Food Chem. 173, 156-162. DOI: 10.1016/j.foodchem.2014.09.162

Guo Z., Jin Q., Fan G., Duan Y., Qin C., Wen M., 2001. Microwave-assisted extraction of effective constituents from a Chinese herbal medicine Radix puerariae. Anal. Chim. Acta 436, 41-47.

Gurjar M.S., Ali S., Akhtar M., Singh K.S., 2012. Efficacy of plant extracts in plant disease management. Agric. Sci. 3, 425-433. DOI: 10.4236/as.2012.33050

Guslandi M., Giollo P., Testoni P.A., 2003. A pilot trial of Saccharomyces boulardii in ulcerative colitis. Eur. J. Gastroenterol. Hepatol., 15, 697-698. DOI: 10.1097/00042737-200306000-00017

Gutarowska B., Piotrowska M., Żakowska Z., Gwoździński K., 2012. Analiza przydatności metod oznaczania adenozynotrifosforanu (ATP) oraz mikroskopii fluorescencyjnej do oceny żywotności i adhezji bakterii na powierzchni bioaktywnych polimerów. Polimery 57, 236-245. DOI: 10.14314/polimery.2012.236

Hać-Szymańczuk E., Cegiełka A., Lipińska E., Czapska S., 2015a. Analiza składu chemicznego i aktywności przeciwdrobnoustrojowej ekstraktów wodnych z wybranych roślin przyprawowych. Zesz. Prob. Post. Nauk Rol. 582, 3-11.

Hać-Szymańczuk E., Lipińska E., Piwowarek K., Filipecka M., 2015b. Aktywność przeciwbakteryjna ekstraktów etanolowych z szałwii i rozmarynu. [W:] Stadnik J., Jackowska I. (red.), Bezpieczeństwo zdrowotne żywności. Aspekty mikrobiologiczne, chemiczne i ocena towaroznawcza. Wydawnictwo Naukowe PTTŻ, Kraków, 47-56.

Hanmoungjai P., Pyle L., Niranjan K., 2000. Extraction of rice bran oil using aqueous media. J. Chem. Technol. Biotechnol. 75(5), 348-352. DOI: 10.1002/(SICI)1097-4660(200005)75:5<348::AIDJCTB233>3.0.CO;2-P

Hao J., Han W., Huang S., Xue D. Deng X., 2002. Microwave assisted extraction of artemisnin from Artemisia annua L. Sep. Purif. Technol. 28, 191-196. DOI: 10.1016/S1383-5866(02)00043-6

Haraguchi H., Tanimoto K., Tamura Y., Mizutani K., Kinoshita T., 1998. Mode of antibacterial action of retrochalcones from Glycyrrhiza inflata. Phytochemistry 48, 125-129. DOI: 10.1016/ s0031-9422(97)01105-9

Harish S., Saravanakumar D., Radjacommare R., Ebenezar E.G., Seetharaman K., 2008. Use of plant extracts and biocontrol agents for the management of brown spot disease in rice. BioControl 53, 555-567. DOI: 10.1007/s10526-007-9098-9

Hayat K., Hussain S., Abbas S., Farooq U., Ding B., Xia S., Jia C., Zhang X., Xia W., 2009. Optimized microwave-assisted extraction of phenolic acids from citrus mandarin peels and evaluation of antioxidant activity in vitro. Sep. Purif. Technol. 70, 63-70. 
He X., Zhang L., Chen J., Sui J., Yi G., Wu J., Ma Y., 2019. Correlation between chemical composition and antifungal activity of Clausena lansium essential oil against Candida spp. Molecules 24(7), E1394. DOI: 10.3390/molecules24071394

Herrero M., Ibáñez E., Cifuentes A., Reglero G., Santoyo S., 2006. Microalga Dunaliella salina pressurized liquid extracts as potential antimicrobials. J. Food Prot. 69(10), 2471-2477. DOI: 10.4315/0362-028x-69.10.2471

Hill C., Guarner F., Reid G., Gibson G.R., Merenstein D.J., Pot B., Morelli L., Canani R.B., Flint H.J., Salminen S., Colder P.C., Sanders M.E., 2014. The international scientific association for probiotics and prebiotics consensus statement on the scope and appropriate use of the term probiotic. Nat. Rev. Gastroenterol. Hepatol. 11, 506-514

Hinds L., Kenny O., Hossain M.B., Walsh D., Sheehy E., Evans P., Gaffney M., Rai D.K., 2017. Evaluating the antibacterial properties of polyacetylene and glucosinolate compounds with further identification of their presence within various carrot (Daucus carota) and broccoli (Brassica oleracea) cultivars using High-Performance Liquid Chromatography with a diode array detector and Ultra Performance Liquid Chromatography - Tandem Mass Spectrometry Analyses. J. Agric. Food Chem. 65(33), 7186-7191. DOI: 10.1021/acs.jafc.7b02029

Hołderna-Kędzia E., Kędzia B., 2012. Działanie preparatów pochodzenia roślinnego na drobnoustroje probiotyczne. Post. Fitoter. 2, 72-77.

Horita C.N., Farías-Campomanes A.M., Barbosa T.S., EsmerinoE.A., Gomes da Cruz A., Bolini H.M.A., Meireles M.A.A., Pollonio M.A.R., 2016. The antimicrobial, antioxidant and sensory properties of garlic and its derivatives in Brazilian low-sodium frankfurters along shelf-life. Food Res. Int. 84, 1-8. DOI: 10.1016/j.foodres.2016.02.006

Horvath G., Jambor N., Vegh A., Böszörmenyi A., Lemberkovics E., Hethelyi E., Kovacsc K., Kocsisc B., 2010. Antimicrobial activity of essential oils: the possibilities of TLC-bioautography. Flavour Fragr. J. 25, 178-182. DOI: 10.1002/ffj.1993

Hsieh P.-C., Mau J.-L., Huang S.-H., 2001. Antimicrobial effect of various combinations of plant extracts. Food Microbiol. 18, 35-43. DOI: 10.1006/fmic.2000.0376

Hua H., Xing F., Selvaraj J.N., Wang Y., Zhao Y., Zhou L., Liu X., 2014. Inhibitory effect of essential oils on Aspergillus ochraceus growth and ochratoxin A production. Plos One 9, 9, e108285. DOI: 10.1371/journal.pone.0108285

Hussain A.I., Anwar F., Rao J.R., Mazumdar A., 2011. Antibacterial activity of some Lamiaceae essential oils using resazurin as an indicator of cell growth. LWT - Food Sci. Technol. 44(4), 1199-1206. DOI: 10.1016/j.1wt.2010.10.005

Hussein R.A., 2016. Isolation and characterization of carotenoid pigment from red pepper fruits (Capsicum annuum L.) and studying its antibacterial activity. Al.-Kufa Univ. J. Biol. 8(3), 515-523. http://www.journals.uokufa.edu.iq/index.php/ajb/article/download/6507/5581

Ilham L.A, Herla R., Suryanto Dwi S., Restuana S.D., 2018. Antimicrobial activity of turmeric leaf extract against Escherichia coli, S. aureus, Shigella dysenteriae and Lactobacillus acidophilus. IOP Conference Series: Earth and Environmental Science, Vol. 205. International Conference on Agribussines, Food and Agro-Technology 19-21 September 2018, Medan, Indonesia.

Issa RA., Talib WH., Habash M., 2016. Phytochemical investigation and antimicrobial activities of Jordanian Psidium guajava raw fruit peel extract using Soxhlet and microwave extraction methods. Res. J. Med. Plants 10, 443-449. DOI: 10.3923/rjmp.2016.443.449

Jach M., Łoś R., Maj M., Malm A., 2013. Probiotyki-aspekty funkcjonalne i technologiczne. Post. Mikrob. 52(2), 161-170.

Jadhav N., Kulkarni S., Mane A., Kulkarni R., Palshetkar A., Kamalinder S., Joshi S., Risbud A., Kalkarni S., 2014. Antibacterial activity of plant extracts against sexually transmitted pathogens. Nat. Prod. Res. 29(16), 1562-1566. DOI: 10.1080/14786419.2014.983919

Jafri A., Bano S., Rais J., Khan F., Shivnath N., Sharma A.K., Arshad M., 2019. Phytochemical screening of Sterculia foetida seed extract for antioxidant, anti-microbial activity, and detection of apoptosis through reactive oxygen species (ROS) generation, mitochondrial membrane poten- 
tial (MMP) decrease, and nuclear fragmentation in human osteosarcoma cells. J. Histotechnol. 42(2), 68-79. DOI: 10.1080/01478885.2019.1592832

Janiszewska E., Witrowa-Rajchert D., 2005. Ekstrakcja nadkrytyczna w przemyśle spożywczym. Żywn. Nauka Technol. Jakość. 4(45), 5-16.

Jankowska M., Swędrzyńska D., 2016. Analiza oddziatywań wybranych drobnoustrojów w środowisku glebowym. Kosmos 65(1), 49-55.

Jeyakumar E., Lawrence R., Pal T., 2011. Comparative evaluation in the efficacy of peppermint oil with standards antibiotics against selected bacterial pathogens. Asian Pacific J. T. Biomed., 253-257.

Jing C., Gou J., Han X., Wu Q., Zhang C., 2017. In vitro and in vivo activities of eugenol against tobacco black shank caused by Phytophthora nicotianae. Pest. Biochem. Physiol. 142, 148-154. DOI: 10.1016/j.pestbp.2017.07.001

Jorgensen J.H., Ferraro M.J., 2009. Antimicrobial susceptibility testing: a review of general principles and practices. Clin. Infect. Dis. 49, 1749-1755. DOI: 10.1086/647952

Ju Z.Y., Howard L.R., 2003. Effects of solvent and temperature on pressurized liquid extraction of anthocyanins and total phenolics from dried red grape skin. J. Agric. Food Chem. 51(18), 5207-5213. DOI: 10.1021/jf0302106

Kabera J.N., Semana E., Mussa A.R., He X., 2014. Plant secondary metabolites: biosynthesis, classification, function and pharmacological properties. J. Pharm. Pharmacol. 2(7), 377-392. DOI: $10.12691 /$ jaem-5-1-4

Karabegović I., Nikolova M., Veličković D., Stojicevic S., Veljkovic V., Lazic M., 2011. Comparison of antioxidant and antimicrobial activities of methanolic extracts of the Artemisia sp. recovered by different extraction techniques. Chin. J. Chem. Eng. 19(3), 504-511. DOI: 10.1016/S10049541(11)60013-X

Kędzia A., 2010. Przeciwdrobnoustrojowe działanie czosnku (Allium sativum L.). Post. Fitoter. 1, 46-52.

Khan N.T., 2017. Antifungal potency of Foeniculum vulgare seed extract. J. Tissue Sci. Engin. 8(3), 1000207. DOI: $10.4172 / 2157-7552.1000207$

Khangholi S., Rezaeizadeh A., 2008. Effect of drying temperature on essential oil content and composition of sweet wormwood (Artemisia annua) growing wild in Iran. Pak. J. Biol. Sci. 11(6), 934-937. DOI: $10.3923 /$ pjbs.2008.934.937

Khosravi-Darani K., 2010. Research activities on supercritical fluid science in food biotechnology. Crit. Rev. Food Sci. Nutr. 50(6), 479-488. DOI: 10.1080/10408390802248759

Kizil S., Hasimi N., Tolan V., Kilinc E., 2010. Mineral content, essential oil components and biological activity of two mentha species (M. piperita L., M. spicata L.). Turkish J. Field Crops 2, 148-153.

Kopeć A., Nowacka E., Leszczyńska T., 2011. Charakterystyka i prozdrowotne właściwości steroli roślinnych. Żywn. Nauka. Technol. Jakość 3(76), 5-14.

Kotowska M., Albrecht P., Szajewska H., 2005. Saccharomyces boulardii in the prevention of antibiotic-associated diarrhoea in children: a randomized double-blind placebo-controlled trial. Aliment. Pharmacol. Ther. 21, 583-590. DOI: 10.1111/j.1365-2036.2005.02356.x

Kozłowska M., Czekała Ł., 2017. Stilbenes and their role in disease resistance. Prog. Plant Prot. 57(1), 27-35. DOI: 10.14199/ppp-2017-004

Kraśniewska K., Gniewosz M., Bączek K., Kosakowska O., 2011. Przeciwdrobnoustrojowa aktywność ekstraktu z ktączy bergenii grubolistnej (Bergenia crassifolia (L.) Fritsch). Bromat. Chem. Toksykol. 3, 662-666.

Kratchanova M., Pavlova E., Panchev I., 2004. The effect of microwave heating of fresh orange peels on the fruit tissue and quality of extracted pectin. Carbohydr. Polym. 56, 181-86. DOI: 10.1016/j.carbpol.2004.01.009

Krishnaveni T., Valliappan R., Selvaraju R., Prasad P.N., 2016. Preliminary phytochemical, physicochemical and antimicrobial studies of Loranthus elasticus of Loranthaceae family. J. Pharmacogn. Phytochem. 5(6), 7-11.

Kubiszewska I., Januszewska M., Rybka J., Gackowska L., 2014. Bakterie kwasu mlekowego: czy probiotyki sa bezpieczne dla czlowieka?. Post. Hig. 68, 1325-1334. 
Kulczyński B., Gramza-Michałowska A., Kmiecik D., Kobus-Cisowska J., 2017. Właściwości prozdrowotne gorzkiego melona. Probl. Hig. Epidemiol. 98(3), 233-239.

Kumar V., Tyagi D., 2013. Antifungal activity evaluation of different extracts of Bergenia stracheyi. Int. J. Curr. Microbiol. App. Sci. 2(7), 69-78.

Kurzawińska H., 2016. Preparaty naturalne $w$ ochronie ziemniaka przed alternarioza. Farmer 4, $156-162$.

Kusznierewicz B., 2017. Nieodżywcze substancje prozdrowotne pochodzenia roślinnego. [W:] Sikorski Z.E., Staroszczyk H. (red.), Chemia żywności 2. Biologiczne właściwości składników żywności. Wydawnictwo WNT, Warszawa, 65-121.

Lamuela-Raventós R.M., 2017. Folin-Ciocalteu method for the measurement of total phenolic content and antioxidant capacity. [In:] Apak R., Capanoglu E., Shahidi F. (eds.), Measurement of Antioxidant Activity and Capacit. John Wiley \& Sons, Hoboken, 107-115. DOI: 10.1002/9781119135388. ch6

Lang Q., Wai C.M., 2001. Supercritical fluid extraction in herbal and natural product studies a practical review. Talanta 53, 771-782. DOI: 10.1016/s0039-9140(00)00557-9

Latif S., Anwar F., 2011. Aqueous enzymatic sesame oil and protein extraction. Food Chem. 125(2), 679-684. DOI: 10.1016/j.foodchem.2010.09.064

Lee W., Lee D.G., 2014. An antifungal mechanism of curcumin lies in membrane-targeted action within Candida albicans. IUBMB Life 66, 780-785. DOI: 10.1002/iub.1326

Lee W.X., Basri D.F., Ghazali A.R., 2017. Bactericidal effect of pterostilbene alone and in combination with gentamicin against human pathogenic bacteria. Molecules 22(3), E463. DOI: 10.3390/molecules22030463

Lemus-Mondaca R., Ah-Hen K., Vega-Gálvez A., Honores K., Moraga N., 2016. Stevia rebaudiana leaves: effect of drying process temperature on bioactive components, antioxidant capacity and natural sweeteners. Plant Food. Hum. Nutr. 71, 49-56. DOI: 10.1007/s11130-015-0524-3

Leng L.Y., Nadzri N., Shaari A.R., Norawanis A.R., Khor C.Y., 2017. Antioxidant capacity and total phenolic content of fresh, oven-dried and stir-fried tamarind leaves. Curr. Res. Nutr. Food Sci. 5(3), 282-287.

Li B.B., Smitha B., Hossain M., 2006. Extraction of phenolics from citrus peels : solvent extraction method. Sep. Purif. Technol. 48(2), 182-188. DOI: 10.1016/j.seppur.2005.07.005

Li H., Chen B., Zhang Z., Yao S., 2004a. Focused microwave assisted solvent extraction and HPLC determination of effective constituents in Eucommia ulmoides Oliv. Talanta 63, 659-665. DOI: 10.1016/j.talanta.2003.12.028

Li H., Pordesimo L., Weiss J., 2004b. High intensity ultrasoundassisted extraction of oil from soybeans. Food Res. Intern. 37, 731-738. DOI: 10.1016/j.foodres.2004.02.016

Li W.-R., Shi Q.-S., Dai H.-Q., Liang Q., Xie X.-B., Huang X.-M., Zhao G.-Z., Zhang L.-X., 2016. Antifungal activity, kinetics and molecular mechanism of action of garlic oil against Candida albicans. Sci. Rep. 6, 1-9. DOI: 10.1038/srep22805

Li Y., Fabiano-Tixier A.S., Vian M.A., Chemat F., 2013. Solvent-free microwave extraction of bioactive compounds provides a tool for green analytical chemistry. Trends Anal. Chem. 47, 1-11. DOI: $10.1016 /$ j.trac.2013.02.007

Li Y., Skouroumounis G.K., Elsey G.M., Taylor D.K., 2011. Microwave-assistance provides very rapid and efficient extraction of grape seed polyphenols. Food Chem. 129, 570-576. DOI: 10.1016/j.foodchem.2011.04.068

Li Y., Ye Z., Wang W., Yang C., Liu J., Zhou L., Shen Y., Wang Z., Chen J., Wu S., Zhang L., 2018. Composition analysis of essential oil from Melaleuca bracteata leaves using ultrasound-assisted extraction and its antioxidative and antimicrobial activities. BioResources 13(4), 8488-8504.

Liang N., Kitts D., 2014. Antioxidant property of coffee components: assessment of methods that define mechanisms of action. Molecules 19(11), 19180-19208. DOI: 10.3390/molecules 191119180

Libudzisz Z., Kowal K., Żakowska Z. (red.), 2008. Mikrobiologia techniczna, t. 2. Wyd. Nauk. PWN, Warszawa. 
Lis B., Grabek-Lejko D., 2016. Mniszek lekarski (Taraxacum officinale) - potencjalne właściwosci prozdrowotne. Nauka Przyr. Technol. 10(3), 1-15. DOI: 10.17306/J.NPT.2016.3.37

Liu J., Sandahl M., Sjoberg P.J., Turner C., 2013. Pressurised hot water extraction in continuous flow mode for thermolabile compounds: extraction of polyphenols in red onions. Anal. Bioanal. Chem. 406(2), 441-445. DOI: 10.1007/s00216-013-7370-7

Liu W., Li L.P., Zhang J.D., 2014. Synergistic antifungal effect of glabridin and fluconazole. Plos One 9, e103442. DOI: 10.1371/journal.pone.0103442

Louli V., Folas G., Voutsas E., Magoulas K., 2004. Extraction of parsley seed oil by supercritical $\mathrm{CO}_{2}$ J. Supercrit. Fluid. 30, 163-174. DOI: 10.1016/j.supflu.2003.07.003

Lucchesi M.E., Chemat F., Smadja J., 2004. Solvent-free microwave extraction of essential oil from aromatic herbs: comparison with conventional hydro-distillation. J. Chromatograp. A. 1043(2), 323-327. DOI: 10.1016/j.supflu.2003.07.003

Luque de Castro M.D., Garcia-Ayuso L.E., 1998. Soxhlet extraction of solid materials: An outdated technique with a promising innovative future. Anal. Chim. Acta 369, 1-10.

Ma J., Xu R.R., Lu Y., Ren D.F., Lu J., 2018. Composition, antimicrobial and antioxidant activity of supercritical fluid extract of Elsholtzia ciliate. J. Essent. Oil Bear. Pl. 21(2), 556-562. DOI: 10.1080/0972060X.2017.1409657

Maćkiw E., Tomczuk K., Rzewuska K., 2012. Badanie możliwości hamowania wzrostu Helicobacter pylorii przez substancje niestosowane standardowo w terapii eradykacyjnej. Post. Fitoter. 2, 119-123.

Maffei M., 2010. Sites of synthesis, biochemistry and functional role of plant volatiles. S. Afr. J. Bot. 28(8), 612-631. DOI: 10.1016/j.sajb.2010.03.003

Mahesh B., Satish S., 2008. Antimicrobial activity of some important medicinal plant against plant and human pathogens. World J. Agric.Sci. 4(S), 839-843.

Makowska-Wąs J., Janeczko Z., 2004. Biodostępność polifenoli roślinnych. Post. Fitoter. 3, 126-137.

Mamidipally P.K., Liu S.X., 2004. First approach on rice bran oil extraction using limonene. Eur. J. Lipid Sci. Tech. 106, 122-125. DOI: 10.1002/ej1t.200300891

Mandras N., Nostro A., Roana J., Scalas D., Banche G., Ghisetti V., Del Re S., Fucale G., Cuffini A.M., Tullio V., 2016. Liquid and vapour-phase antifungal activities of essential oils against Candida albicans and non-albicans Candida. BMC Compl. Altern. Med. 16, 330. DOI: 10.1186/ s12906-016-1316-5

Marjańska-Cichoń B., Sapieha-Waszkiewicz A., 2011. Skuteczność wyciagów z czosnku w zwalczaniu szarej pleśni truskawki. Prog. Plant Prot. 51(1), 413-420.

Markowiak P., Śliżewska K., 2017. Effects of probiotics, prebiotics, and synbiotics on human health. Nutrients 9(9), 10-21. DOI: 10.3390/nu9091021

Marston A., 2013. Thin-layer chromatography with biological detection in phytochemistry. J. Chromatogr. A. 1218, 2676-2683. DOI: 10.1016/j.chroma.2010.12.068

Martinelli L., Rosa J.M., Ferreira C.S.B., Nascimento G.M.L., Freitas M.S., Pizato L.C., Santos W.O., Pires R.F., Okura M.H., Malpass G., Granato A.C., 2017. Antimicrobial activity and chemical constituents of essential oils and oleoresins extracted from eight pepper species. Ciência Rural 47(5), e20160899. DOI: 10.1590/0103-8478cr20160899

Martucci J.F., Gende L.B., Neira L.M., Ruseckaite R.A., 2015. Oregano and lavender essential oils as antioxidant and antimicrobial additives of biogenic gelatin films. Ind. Crop. Prod. 71, 205-213.

Mašković P., Veličković V., Mitić M., Đurović S., Zekovićb Z., Radojković M., Cvetanović A., Švarc-Gajićb J., Vujić J., 2017. Summer savory extracts prepared by novel extraction methods resulted in enhanced biological activity. Ind. Crop. Prod. 109, 875-881.

Melo M.M.R. de, Silvestre A.J.D., Silva C.M., 2014. Supercritical fluid extraction of vegetable matrices: applications, trends and future perspectives of a convincing green technology. J. Supercrit. Fluids. 92, 11-176.

Merkl R., Hrádková I., Filip V., Šmidrkal J., 2010. Antimicrobial and antioxidant properties of phenolic acids alkyl esters. Czech. J. Food Sci. 28, 275-279. DOI: 10.17221/132/2010-CJFS 
Meyer A.S., Suhr K.I., Nielsen P., 2002. Natural food preservatives. [In:] Ohlsson T., Bengtsson N. (eds.), Minimally processing in the food industry. Woodhead Publishing, Cambridge.

Michel T., Destandau E., Le Floch G., Lucchesi M.E., Elfakir C., 2012. Antimicrobial, antioxidant and phytochemical investigations of sea buckthorn (Hippophaë rhamnoides L.) leaf, stem, root and seed. Food Chem. 131(3), 754-760. DOI: 10.1016/j.foodchem.2011.09.029

Mihaylova D., Lante A., Tinello F., Krastanov A.I., 2014. Study on the antioxidant and antimicrobial activities of Allium ursinum L. pressurised-liquid extract. Nat. Prod. Res. 28(22), 2000-2005. DOI: $10.1080 / 14786419.2014 .923422$

Mikuła-Pietrasik J., Kuczmarska A., Książek K., 2015. Biologiczna wielofunkcyjność resweratrolu i jego pochodnych. Post. Bioch. 61(4), 336-343.

Mišić D., Zizovic I., Stamenić M., Ašanin R., Ristić M., Petrović S.D., Skala D., 2008. Antimicrobial activity of celery fruit isolates and SFE process modeling. Biochem. Eng. J. 42(2), 148-152. DOI: $10.1016 /$ j.bej.2008.06.008

Mithöfer A., Boland W., 2012. Plant defense against herbivores: chemical aspects. Annu. Rev. Plant. Biol. 63, 431-450. DOI: 10.1146/annurev-arplant-042110-103854

Moliszewska E.B., Burgieł Z.J., 1998. Wpływ wyciagów roślinnych na rozwój grzybów patogenicznych. Chem. Inz. Ekol. 5(7), 603-612.

More N.V., Kharat A.S., 2016. Antifungal and anticancer potential of Argemone mexicana L. Medicines 3(4), E28. DOI: 10.3390/medicines3040028

Moreno S., Scheyer T., Romano C.S., Vojnov A.A., 2006. Antioxidant and antimicrobial activities of rosemary extracts linked to their polyphenol composition. Free Radic. Res. 40, 223-231. DOI: 10.1080/10715760500473834

Mostafa A.A., Al-Askar A.A., Almaary K.S., Dawoud T.M., Sholkamy E.N., Bakri M.M., 2018. Antimicrobial activity of some plant extracts against bacterial strains causing food poisoning diseases. Saudi J. Biol. Sci. 25, 361-366. DOI: 10.1016/j.sjbs.2017.02.004

Muhammad J.S., Zaidi S.F., Shaharyar S., Refaat A., Usmanghani K., Saiki I., Sugiyama T., 2015. Anti-inflammatory effect of cinnamaldehyde in Helicobacter pylori induced gastric inflammation. Biol Pharm Bull. 38(1), 109-115. DOI: 10.1248/bpb.b14-00609

Mundy L., Pendry B., Rahman M., 2016. Antimicrobial resistance and synergy in herbal medicine. J. Herb. Med. 6, 53-58. DOI: 10.1186/s12906-018-2264-Z

Murthy CH.K.N, Vanitha A., Swamy M., Ravishankar G.A., 2003. Antioxidant and antimicrobial activity of Cissus quadrangularis L. J. Med. Food. 6(2), 99-105. DOI: 10.1089/109662003322233495

Mustafa A., Turner C., 2011. Pressurized liquid extraction as a green approach in food and herbal plants extraction: A review. Anal. Chim. Acta 703(3), 8-18. DOI: 10.1016/j.aca.2011.07.018

Muszyńska B., Mastej M., Sułkowska-Ziaja K., 2016. Biological function of carotenoids and their occurrence in the fruiting bodies of mushrooms. Med. Int. Rev. 107(2), 113-122.

Muth D., Kachlicki P., 2009. Metody analizy flawonoidów w materiale roślinnym. Biotechnologia 2(85), 65-80.

Nanjundaiah S.M., Annaiah H.N.M., Dharmesh S.M., 2011. Gastroprotective effect of ginger rhizome (Zingiber officinale) extract: role of gallic acid and cinnamic acid in $\mathrm{H}^{+}, \mathrm{K}^{+}-$ATPase/H. pylori inhibition and anti-oxidative mechanism. Evid. Based Complement. Altern. Med. 2, 249427. DOI: $10.1093 /$ ecam/nep060

Nawrocki E.M., Bedell H.W., Humphreys T.L., 2013. Resveratrol is cidal to both classes of Haemophilus ducreyi. Int. J. Antymicrob. Agents 41, 477-479. DOI: 10.1016/j.ijantimicag.2013.02.008

Nazzaro F., Fratianni F., Coppola R., De Feo V., 2017. Essential oils and antifungal activity. Pharmaceuticals 10(4), 86. DOI: 10.3390/ph10040086

Ncube N., Afolayan S.A.J., Okoh A.I., 2008. Assessment techniques of antimicrobial properties of natural compounds of plant origin: Current methods and future trends. Afr. J. Biotechn. 7, 1797-1806.

Ngouana T.K., Mbouna C.D.J., Kuipou R.M.T., Tchuenmogne M.A.T., Zekuo’o E.M., Ngouana V., Mallié M., Bertout S., Boyom F.F., 2015. Potent and synergistic extract combinations from 
Terminalia catappa, Terminalia mantaly and Monodora tenuifolia against pathogenic yeasts. Medicines 2, 220-235. DOI: 10.3390/medicines2030220

Nieto A., Borrull F., Pocurull E., Marcé R.M., 2010. Pressurized liquid extraction: a useful technique to extract pharmaceuticals and personal-care products from sewage sludge. Trends Anal. Chem. 29(7), 752-764.

Nowak A., Śliżewska K., Libudzisz Z., Socha J., 2010. Probiotyki - efekty zdrowotne. Żywn. Nauka. Technol. Jakość. 4(71), 20-36.

Nurzyńska-Wierdak R., Bogucka-Kocka A., Kowalski R., Borowski B., 2012. Changes in the chemical composition of the essential oil of sweet basil (Ocimum basilicum L.) depending on the plant growth stage. Chemija 23(3), 216-222.

Nybond S., Karp M., Ysjönen T., Tammela P., 2015. Bioluminescent whole-cell reporter gene assays as screening tools in the identification of antimicrobial natural product extracts. J. Microbiol. Met. 114, 54-56. DOI: 10.1016/j.mimet.2015.04.014

Obiang C.S., Ngoua Meye Misso R.L., Ndong Atome G.R., Ondo J.P., Obame Engonga L.C., Emvo E.N., 2019. Phytochemical analyses, antimicrobial and antioxidant activities of stem bark extracts of Distemonanthus benthamianus H. Baill. and fruit extracts of Solanum torvum Sw. from Gabon. Asian Pac. J. Trop. Biomed. 9, 209-216. DOI: 10.4103/2221-1691.259001

Ohemeng K.A., Schwender C.F., Fu K.P., Barrett J.F., 1993. DNA gyrase inhibitory and antibacterial activity of some flavones (1). Bioorg. Med. Chem. Lett. 3(2), 225-230. DOI: 10.1016/ S0960-894X(01)80881-7

Olszewska M., Kocot A., Łaniewska-Trokenheim Ł., 2016. Analiza cytometryczna w mikrobiologicznych badaniach żywności. Med. Weter. 72, 162-167.

Omar S.H., Al-Wabel N.A., 2010. Organosulfur compounds and possible mechanism of garlic in cancer. Saudi. Pharm. J. 18, 51-58. DOI: 10.1016/j.jsps.2009.12.007

Oreščanin V., Findri-Guštek S., Hunjak B., 2015. Application of new herbal pessaries for the treatment of the lower genital tract infections. Int. J. Appl. Res. 5(6), 510-514.

Ortega-Ortega M.A., Cruz-Cansino N.S., Alanís-García E., Delgado-Olivares L., Ariza-Ortega J.A., Ramírez-Moreno E., Manríquez-Torres J.J., 2017. Optimization of ultrasound extraction of cactus pear (Opuntia ficus indica) seed oil based on antioxidant activity and evaluation of its antimicrobial activity. J. Food Quality 71, 1-9. DOI: 10.1155/2017/9315360

Pajor K., Sypniewski D., Bednarek I., 2017. Bioluminescencja jako narzędzie w biologii molekularnej. Postępy Hig. Med. Dosw. 71, 1033-1049.

Pan X., Niu G., Liu H., 2001. Microwave assisted extraction of tanshinones from Salvia miltiorrhiza bunge with analysis by high performance liquid chromatography. J. Chromatogr. A. 922, 371-75. DOI: 10.1016/s0021-9673(01)00949-9

Pan X., Niu G., Liu H., 2003. Microwave assisted extraction of tea polyphenols and tea caffeine from green tea leaves. Chem. Eng. Process. 42, 129-133. DOI: 10.1016/S0255-2701(02)00037-5

Pan X.J., Liu H.Z., Jia G.H., Shu Y.Y., 2000. Microwave-assisted extraction of glycyrrhizic acid from licorice root. Biochem. Eng. J. 5, 173-177. DOI: 10.1016/s1369-703x(00)00057-7

Pandya M.P., Sameja K.D., Patel D.N., Bhatt K.D., 2017. Antimicrobial activity and phytochemical analysis of medicinal plant Cassia tora. Int. J. Pharm. Chem. 3(4), 56-61.

Paparella A., Taccogna L., Aguzzi I., Chaves-Lopez C., Serio A., Marsilio F., Suzzi G., 2008. Flow cytometric assessment of the antimicrobial activity of essential oils against Listeria monocytogenes. Food Control. 19, 1174-1182.

Parekh J., Jadeja D., Chanda S., 2005. Efficacy of aqueous and methanol extracts of some medicinal plants for potential antibacterial activity. Turk. J. Biol. 29, 203-210.

Passone M.A., Girardi N.S., Etcheverry M., 2012. Evaluation of the control ability of five essential oils against Aspergillus section Nigri growth and ochratoxin A accumulation in peanut meal extract agar conditioned at different water activities levels. Int. J. Food Microbiol. 159, 198-206. DOI: 10.1016/j.ijfoodmicro.2012.08.019

Patkowska E., 2006. Effectiveness of grejpfrut extract and Pythium oligandrum in the control of bean and peas pathogens. J. Plant Prot. Res. 46, 15-28. 
Périno S., Pierson J.T., Ruiz K., Cravotto G., Chemat F., 2016. Laboratory to pilot scale: Microwave extraction for polyphenols lettuce. Food Chem. 204, 108-114. DOI: 10.1016/j.foodchem.2016.02.088

Petrović N., Petrović S.S., Džamić A.M., Ćirić A.D., Ristić M.S., Milovanović S., Petrović S., 2016. Chemical composition, antioxidant and antimicrobial activity of Thymus praecox supercritical extracts. J. Supercritical Fluids 110, 117-125. DOI: 10.1016/j.supflu.2016.01.001

Piekut J., 2017. Ocena wybranych ekstraktów roślin przyprawowych pod względem ich właściwości przeciwdrobnoustrojowych oraz zawartości fenolokwasów. Zesz. Problem. Post. Nauk Rol. 588, $103-111$.

Pingret D., Fabiano-Tixier A.-S., Chemat F., 2014. An improved ultrasound Clevenger for extraction of essential oils. Food Anal. Methods 7(1), 9-12. DOI: 10.1007/s12161-013-9581-0

Pingret D., Fabiano-Tixier A.-S., Le Bourvellec C., Renard C.M., Chemat F., 2012. Lab and pilot-scale ultrasound-assisted water extraction of polyphenols from apple pomace. J. Food Eng. 111(1), 73-81. DOI: 10.1016/j.jfoodeng.2012.01.026

Pinna R., Filigheddu E., Juliano C., Palmieri A., Manconi M., D'hallewin G., Petretto G., Maioli M., Caddeo C., Manca M.L., Solinas G., Bortone A., Campanella V., Milia E., 2019. Antimicrobial effect of Thymus capitatus and Citrus limon var. pompia as raw extracts and nanovesicles. Phaurmaceutics 11(5), 234. DOI: 10.3390/pharmaceutics11050234

Piotrowski W., Sas-Piotrowska B., Wyrostkiewicz K., Czajkowski P., 1995. Wpływ wyciagów roślinnych na kiełkowanie zarodników niektórych gatunków grzybów patogenicznych dla roślin. Zesz. Nauk. ATR Bydgoszcz 190, Rol. 36, 139-145.

Plaper A., Golob M., Hafner I., Oblak M., Solmajer T., Jerala R., 2003. Characterization of quercetin binding site on DNA gyrase. Biochem. Biophys. Res. Commun. 306, 530-536. DOI: 10.1016/ s0006-291x(03)01006-4

Plaza-Díaz J., Ruiz-Ojeda F.J., Gil-Campos M., Gil A., 2018. Immune-mediated mechanisms of action of probiotics and synbiotics in treating pediatric intestinal diseases. Nutrients 10(1), 42. DOI: 10.3390/nu10010042

Putnik P., Kovačević D.B., Penić M., Fegeš M., Dragović-Uzelac V., 2016. Microwave-assisted extraction (MAE) of dalmatian sage leaves for the optimal yield of polyphenols, HPLC-DAD identification and quantification. Food Anal. Method. 9, 2385-2394. DOI: 10.1007/s12161016-0428-3

Puupponen-Pimiä R., Nohynek L., Meier C., Kähkönen M., Heinonen M., Hopia A., Oksman-Caldentey K.-M., 2001. Antimicrobial properties of phenolic compounds from berries. J. Appl. Microbiol. 90, 494-507. DOI: 10.1046/j.1365-2672.2001.01271.x

Pylak M., Oszust K., Frąc M., 2019. Review report on the role of bioproducts, biopreparations, biostimulants and microbial inoculants in organic production of fruit. Rev. Environ. Sci. Biotechnol. 18, 597-616. DOI: 10.1007/s11157-019-09500-5

Pytka M., Kordowska-Wiater M., Jarocki P., 2019. Mikrobiom uktadu ptciowego kobiet. Post. Mikrobiol. 58(3), 227-236. DOI: 10.21307/PM-2019.58.3.227

Quinn J.C., Kessell A., Weston L.A., 2014. Secondary plant products causing photosensitization in grazing herbivores: Their structure, activity and regulation. Int. J. Mol. Sci. 15, 1441-1465. DOI: $10.3390 / \mathrm{ijms} 15011441$

Rajabi H.R., Naghiha R., Kheirizadeh M., Sadatfaraji H., Mirzaei A., Alvand Z.M., 2017. Microwave assisted extraction as an efficient approach for biosynthesis of zinc oxide nanoparticles: synthesis, characterization, and biological properties. Mater. Sci. Eng. C. 78, 1109-1118. DOI: 10.1016/j.msec.2017.03.090

Ramani R., Chaturvedi V., 2000. Flow cytometry antifungal susceptibility testing of pathogenic yeasts other than Candida albicans and comparison with the NCCLS broth microdilution test. Antimicrob. Agents Chemother. 44, 2752-2758. DOI: 10.1128/aac.44.10.2752-2758.2000

Redfern J., Kinninmonth M., Burdass D., Verran J., 2014. Using soxhlet ethanol extraction to produce and test plant material (essential oils) for their antimicrobial properties. J. Microbiol. Biol Educ. 15(1), 45-46. DOI: 10.1128/jmbe.v15i1.656 
Ren X., An P., Zhai X., Wang S., Kong Q., 2019. The antibacterial mechanism of pterostilbene derived from xinjiang wine grape: A novel apoptosis inducer in Staphyloccocus aureus and Escherichia coli. LWT - Food Sci. Technol. 101, 100-106. DOI: 10.1016/j.lwt.2018.11.038

Rodríguez-Meizoso I., Jaime L., Santoyo S., Cifuentes A., García-Blairsy Reina G., Señoráns F.J, Ibáñez E., 2008. Pressurized fluid extraction of bioactive compounds from phormidium species. J. Agric. Food Chem. 56, 3517-3523. DOI: 10.1021/jf703719p

Rosenthal A., Pyle D.L., Niranjan K., 1996. Aqueous and enzymatic processes for edible oil extraction. Enzyme Microb. Tech. 19(6), 402-420. DOI: 10.1016/S0141-0229(96)80004-F

Ross Z.M., O'Gara E.A., Hill D.J., Sleightholme H.V., Maslin D.J., 2001. Antimicrobial properties of garlic oil against human enteric bacteria: evaluation of methodologies and comparisons with garlic oil sulfides and garlic powder. Appl. Environ. Microbiol. 67, 475-480. DOI: 10.1128/ AEM.67.1.475-480.2001

Ruddock P.S., Liao M., Foster B.C., Lawson L., Arnason J.T., Dillon J.A., 2005. Garlic natural health products exhibit variable constituent levels and antimicrobial activity against Neisseria gonorrhoeae, Staphylococcus aureus and Enterococcus faecalis. Phytother. Res. 19(4), 327-334. DOI: $10.1002 /$ ptr.1667

Sagar K., Vidyasagar G.M., 2013. Anti-dermeatophytic activity of some traditionally used medicinal plants of north Karnataka region. J. Appl. Pharm. Sci. 3, 77-83. DOI: 10.7324/JAPS.2013.30213

Şahin S., Samli R., Tan A.S., Barba F.J., Chemat F., Cravotto G., Lorenzo J.M., 2017. Solvent-free microwave-assisted extraction of polyphenols from olive tree leaves: antioxidant and antimicrobial properties. Molecules 22(7), E1056. DOI: 10.3390/molecules22071056

Saibabu V., Fatima Z., Hameid S., 2018. Revising the in vitro assays for antifungal evaluation of natural products. Cur. Pharmacogen. Pers. Med. 16, 69-74. DOI: 10.2174/187569211666618 0405144630

Saković M., Glamoclija J., Marin P.D., Brikić D., Griensven L.J.L.D. van, 2010. Antibacterial effects of the essential oils of commonly consumed medicinal herbs using an in vitro model. Molecules 15, 7532-7546. DOI: 10.3390/molecules 15117532

Salar-Bashi D., Bazzaz B., Sahebkar A., Karimkhani M., Ahmadi A., 2012. Investigation of optimal extraction, antioxidant, and antimicrobial activities of Achillea biebersteinii and A. wilhelmsii. Pharm. Biol. 50(9), 1168-1176. DOI: 10.3109/13880209.2012.662235

Salazar-Lindo E., Miranda-Langschwager P., Campos-Sanchez M., Chea-Woo E., Sack R.B., 2004. Lactobacillus casei strain $G G$ in the treatment of infants with acute watery diarrhea: a randomized, double-blind, placebo controlled clinical trial. BMC Pediatr. 4(18). DOI: 10.1186/1471-2431-4-18

Saniewska A., 1996. Potential use of garlic compounds and fungicides in the control of fungion seeds of some ornamental plants. VII Conf. Pol. Phytopat. Soc. Res. Ins. Pom. Floricul., Skierniewice 18-19 kwietnia 1996, 141-147.

Santoyo S., Herrero M., Señorans F.J., Cifuentes A., Ibáñez E., Jaime L., 2006. Functional characterization of pressurized liquid extracts of Spirulina platensis. Eur. Food Res. Technol. 224, 75-81. DOI: 10.1007/s00217-006-0291-3

Sasidharan S., Chen Y., Saravanan D., Sundram K.M., Yoga-Latha L., 2011. Extraction, isolation and characterization of bioactive compounds from plants' extracts. Afr. J. Tradit. Complement. Altern. Med. 8(1), 1-10.

Scodro R.B., Espelho S.C., Agostinho Pires C.T., Garcia V.A., Cardozo-Filho L., Cortez L.E., 2014. A new benzoic acid derivative from Piper diospyrifolium and its anti-Mycobacterium tuberculosis activity. Phytochem. Lett. 11, 18-23. DOI 10.1016/j.phytol.2014.10.015

Sellami I.H., Wannes W.A., Bettaieb I., Berrima S., Chahed T., Marzouk B., Limam F., 2011. Qualitative and quantitative changes in the essential oil of Laurus nobilis L. leaves as affected by different drying methods. Food Chem. 126, 691-697. DOI: 10.1016/j.foodchem.2010.11.022

Shahat A., El-Barouty G., Hassan R., Hammouda F.M., Abdel-Raman F.H., Saleh M.A., 2008. Chemical composition and antimicrobial activities of the essential oil from the seeds of Enterolobium contortisiliquum (leguminosae). J. Environ. Sci. Health 43, 519-525. DOI: 10.1080/03601230802174714 
Shahhoseini R., Estaji A., Hosseini N., Ghorbanpour M., Omidbaigi R., 2013. The effect of different drying methods on the content and chemical composition of essential oil of lemon verbena (Lippia citriodora). J. Essent. Oil Bear. P1. 16(4), 474-481. DOI 10.1080/0972060X.2013.813270

Shahidi F., Yeo J.D., 2018. Bioactivities of phenolics by focusing on suppression of chronić diseases: A review. J. Mol. Sci. 19, 1573. DOI: 10.3390/ijms19061573

Shama G., Malik D.J., 2013. The uses and abuses of rapid bioluminescence-based ATP assays. Int. J. Hyg. Environ. Health 216, 115-125.

Sharif K.M., Rahman M.M., Azmir J., Mohamed A., Jahurul M.H.A., Sahena F., Zaidul I.S.M., 2014. Experimental design of supercritical fluid extraction-A review. J. Food Engin. 124, 105-116. DOI: $10.1016 /$ j.jfoodeng.2013.10.003

Sharma A., Khare S.K., Gupta M.N., 2002. Enzyme-assisted aqueous extraction of peanut oil. J. Am. Oil Chem. Soc. 79(3), 215-218. DOI: 10.1007/s11746-002-0463-0

Sharma C., Malgaonkar M., Sangvikar S.G., 2016. In vitro evaluation of antimicrobial and antioxidant profile of Grewia L root extracts. J. Appl. Life Sci. Int. 7, 1-9. DOI: 10.9734/JALSI/2016/26748

Shawl A.S., Kumar T., Chishi N., 2006. Cultivation of rose scented Geranium (Pelargonium sp.) as a cash crop in Kashmir Valley. Asian J. Plant Sci. 5, 673-675. DOI: 10.3923/ajps.2006.673.675

Shu Y.Y., Ko M.Y., Chang Y.S., 2003. Microwave assisted extraction of ginsenosides from ginseng root. Microchem. J. 74, 131-139. DOI: 10.1016/S0026-265X(02)00180-7

Silva A.R. da, Andrade Neto J.B., Silva C.R. da, Souosa Campos R., Silva R., Freitas D.D., Nascimentos F.B., Andrade L.N.D., Sampaio L.S., Trangeiro T., Ferreira Magalhaes H.I., Cavalcanti B.C., Moraes M.O., Nobre Junior H.V., 2016. Berberine antifungal activity in fluconazole-resistant pathogenic yeasts: action mechanism evaluated by flow cytometry and biofilm growth inhibition in Candida spp. Antimicrob. Agents Chemother. 60, 3551-3557. DOI: 10.1128/AAC.01846-15

Silva I.C.M. da, Santos W.L. dos, Leal I.C.R., Zoghbi M.D., Feirhmann A.C., Cabral V.F., 2014. Extraction of essential oil from Cyperus articulatus $L$. var. articulates (priprioca) with pressurized $\mathrm{CO}_{2}$ J. Supercrit. Fluids 88, 134-141. DOI: 10.1016/j.supflu.2014.02.001

Silva R.P. da, Rocha-Santos T.A., Duarte A.C., 2016. Supercritical fluid extraction of bioactive compounds. Trends Analyt. Chem. 76, 40-51. DOI: 10.3390/molecules22071186

Skotny A., Pucińska J., 2013. Współczesna cytometria przeptywowa. Inż. Biomed. 19, 3-10.

Skroza D., Šimat V., Možina S.S., Katalinić V., Boban N., Mekinić I.G., 2019. Interactions of resveratrol with other phenolics and activity against food-borne pathogens. Food Sci Nutr. 7, 2312-2318. DOI: 10.1002/fsn3.1073

Slusarenko A.J., Patel A., Portz D., 2008. Control of plant diseases by natural products: allicin from garlic as a case study. [In:] SlusarenkoA.J.,PatelA.,PortzD., Sustainable diseasemamagementin a European context. DOI: $10.1007 / 978-1-4020-8780-610$

Smolinska U., Morra M.J., Knudsen G.R., James R.L., 2003. Isothiocyanates produced by Brassicaceae species as inhibitors of Fusarium oxysporum. Plant Dis. 87(4), 407-412. DOI: 10.1094/ PDIS.2003.87.4.407

Soetan O., Oyekunle M.A., Aiyelaagbe O., Fafunso M.A., 2006. Evaluation of the antimicrobial activity of saponins extract of Sorghum Bicolor L. Moench. Afr. J. Biotechnol. 5(23), 2405-2407.

Soria A.C., Villamiel M., 2010. Effect of ultrasound on the technological properties and bioactivity of food, a review. Trends Food Sci. Technol. 21(7), 323-331. DOI: 10.1016/j.tifs.2010.04.003

Sovilj M.N., Nikolovski B.G., Spasojevic M.D., 2011. Critical review of supercritical fluid extraction of selected spice plant materials. Maced. J. Chem. Chem. Eng. 30, 197-220.

Soylu S., Yigitbas H., Soylu E.M., Kurt S., 2007. Antifungal effects of essentials oils from oregano and hennel on Sclerotinia sclerotiorum. J. Appl. 103, 1021-1030. DOI: 10.1007/s11046-005-0206-Z

Steinka I., 2011. Wybrane aspekty stosowania probiotyków. Ann. Acad. Med. Gedan. 41, 97-108.

Stepnowski P., Synak E., Szafranek B., Kaczyński Z., 2010. Techniki separacyjne. Wyd. Uniwersytetu Gdańskiego, Gdańsk.

St-Gelais A., Legault J., Mshvildadze V., Pichette A., 2015. Dichromones: cytotoxic organic sulfur compounds isolated from Dirca palustris. J. Nat. Prod. 78, 1904-1909. DOI: 10.1021/asc. jnatprod.5b00227 
Stobnicka A., Gniewosz M., Miętuszewska A., 2011. Przeciwbakteryjne działanie soków owocowych z żurawiny, rokitnika, noni i goji. Bromat. Chem. Toksyk. 44(3), 650-655.

Stoicov C., Saffari R., Foughton J.M., 2009. Green tea inhibits Helicobacter growth in vivo in vitro. Int. J. Antimicrob. Agents. 33(5), 473-478. DOI: 10.1016/j.ijantimicag.2008.10.032

Suhaj M., 2006. Spice antioxidants isolation and their antiradical activity: a reviews. J. Food Comp. Anal. 19, 531-537. DOI: 10.1016/j.jfca.2004.11.005

Suleiman M., McGaw L., Naidoo V., Eloff J.N., 2010. Detection of antimicrobial compounds by bioautography of different extracts of leaves of selected South African tree species. Afr. J. Tradit. Complement. Altern. Med. 7, 64-78. DOI: 10.4314/ajtcam.v7i1.57269

Synowiec A., Gniewosz M., Bączek K., Węglarz Z., 2011. Przeciwdrobnoustrojowe działanie wodno-etanolowego ekstraktu z liści borówki czernicy (Vaccinium myrtillus L.). Bromat. Chem. Toksykol. 44(3), 656-661.

Szosland-Fałtyn A., Królasik J., 2014. Metoda bioluminescencyjna oznaczania ATP jako alternatywna metoda detekcji drobnoustrojów w przemyśle spożywczym. Postęp. Nauk. Technol. Przem. $69,37-43$.

Tagousop C.N., Tamokou J.-de-D., Ekom S.E., Ngnokam D., Voutquenne-Nazabadioko, 2018. Antimicrobial activities of flavonoid glycosides from Graptophyllum grandulosum and their mechanism of antibacterial action. BMC Complem. Altern. Med. 18, 252. DOI: 10.1186/s12906-018-2321-7

Tahir H.A.S., Sahi S.T., Habib A., Haq I.U., Ahmad A., Ashraf W., 2016. Evaluation of plant extracts as biocontrol agents against Xanthomonas axonopodis pv. citri the cause of citrus canker. Pak. J. Phytopathol. 28(01), 35-43.

Takeuchi H., Trang V.T., Morimoto N., Nishida Y., Matsumura Y., Sugiura T., 2014. Natural products and food components with anti-Helicobacter pylori activities. World J. Gastroenterol. 20(27), 8971-8978. DOI: 10.3748/wjg.v20.i27.8971

Talebi M., Ghassempour A., Talebpour Z., Rassouli A., Dolatyari L., 2004. Optimization of the extraction of paclitaxel from Taxus baccata L. by the use of microwave energy. J. Sep. Sci. 27, 1130-1136. DOI: $10.1002 /$ jssc.200401754

Tamene D., Endale M., 2019. Antibacterial activity of coumarins and carbazole alkaloid from roots of clausena anisata. Adv. Pharmacol. Sci. 3, e5419854. DOI: 10.1155/2019/5419854

Tian J., Ban X., Zeng H., He J., Chen Y., Wang Y., 2012. The mechanism of antifungal action of essential oil from dill (Anethum graveolens L.) on Aspergillus flavus. Plos One 7, e30147. DOI: 10.1371/journal.pone.0030147

Tian J., Ban X.Q., Zeng H., Huang B., He J.S., 2011. In vitro and in vivo activity of essential oil from dill (Anethum graveolens L.) against fungal spoilage of cherry tomatoes. Food Control. 22, 1992-1999.

Tiwari R.K.S., Chandravanshi S.S., Ojha B.M., 2005. Efficacy of extracts of medicinal plant species on growth of Sclerotium rolfsii root rot in tomato. Indian J. Mycol. Pl. Pathol. 3, 461-464.

Toiu A., Mocan A., Vlase L., Pârvu A.E., Bodnar D.C., Gheldiu A.-M., Moldovan C., Oniga I., 2019. Comparative phytochemical profile, antioxidant and in vivo anti-inflammatory activity of different extracts of traditionally used Romanian Jurga genevensis L. and A. repans L.(Lamiaceae). Molecules 24, 1597. DOI: 10.3390/molecules24081597

Tomazoni E.Z., Pauletti G.F., Silva Ribeiro R.T. da, Moura S., Schwambach J., 2017. In vitro and in vivo activity of essential oils extracted from Eucalyptus staigeriana, Eucalyptus globules and Cinnamonum camphora against Alternaria solani Sorauer causing early blight in tomato. Sci. Hortic. 223, 72-77.

Tsubaki S., Sakamoto M., Azuma J., 2010. Microwave-assisted extraction of phenolic compounds from tea residues under autohydrolytic conditions. Food Chem. 123, 1255-1258. DOI: 10.1016/j. foodchem.2010.05.088

Vediyappan G., Dumontet V., Pelissier F., d'Enfert C., 2013. Gymnemic acids inhibit hyphal growth and virulence in Candida albicans. Plos One 8, e74189. DOI: 10.1371/journal.pone.0074189 
Veličkovska S.K., Letia G.N., Čočevska M., Brühl L., Dumitrescu R.S., Mirhosseini H., Ilieva F., Mihajlov L., Dimovska V., Kovacevič B., Gulaboski R., Matthäus B., 2018. Effect of bioactive compounds on antiradical and antimicrobial activity of extracts and cold-pressed edible oils from nutty fruits from Macedonia. J. Food Meas. Charact. 12, 2545-2552. DOI: 10.1007/ s11694-018-9871-8

Vieitez I., Maceiras L., Jachmanián I., Alborés S., 2018. Antioxidant and antibacterial activity of different extracts from herbs obtained by maceration or supercritical technology. J. Supercrit. Fluid. 133, 58-64.

Vongsak B., Sithisarn P., Mangmool S., Thongpraditchote S., Wongkrajang Y., 2013. Maximizing total phenolics, total flavonoids contents and antioxidant activity of Moringa oleifera leaf extract by the appropriate extraction method. Ind. Crops Prod. 44, 566-571. DOI: 10.1016/j. indcrop.2012.09.021

Wang L., Weller C.L., 2006. Recent advances in extraction of nutraceuticals from plants. Trends Food. Sci. Tech. 17(6), 300-312. DOI: 10.1016/j.tifs.2005.12.004

Wang S., Chan F., Wu J., Wang Z., Liao X., Ha X., 2007. Optimization of pectin extraction assisted by microwave from apple pomance using response surface methodology. J. Food Eng. 78(2), 693-700.

Wang T., Jonsdottir R., Kristinsson H.G., Hreggvidsson G.O., Jonsson J.O., Thorkelsson G., Olafsdottir G., 2010. Enzyme-enhanced extraction of antioxidant ingredients from red algae Palmaria palmata. LWT - Food Sci. Technol. 43(9), 1387-1393. DOI: 10.1016/j.lwt.2010.05.010

Ward P.M., Fajitsas S., Katz M., 2002. Inhibition, resistance development, and increased antibiotic and antimicrobial resistance by nutraceuticals. J. Food. Prot 65, 528-533.

Wavare S.H., Gade R.M., Shitole V., 2017. Effect of plant extracts, bio agents and fungicides against Sclerotium rolfsii causing collar rot in chickpea. Indian J. Pharm. Sci. 79(4), 513-520. DOI: 10.4172/pharmaceutical-sciences. 1000257

Wierzbicka M., 2001. Grzybica kropidlakowa phuc (aspergiloza). Post. Nauk Med. 1, 36-41.

Williams J.H., Phillips T., Jolly P.E., Stiles J.K., Jolly C.M., 2004. Human aflatoxicosis in developing countries: a review of toxicology, exposure, potential health consequences, and interventions. Am. J. Clin. Nutr. 80, 1106-1122. DOI: 10.1093/ajen/80.5.1106

Wrzeciono U., Zapruto L., 2001. Chemia związków naturalnych. Akademia Medyczna im. Karola Marcinkowskiego, Poznań.

Xie J.-H., Shena M.Y., Xiea M.Y., Nie S.P., Chena Y., Li C., Huanga D.F., Wang Y.X., 2012. Ultrasonic-assisted extraction, antimicrobial and antioxidant activities of Cyclocarya paliurus (Batal.) Iljinskaja polysaccharides. Carbohydr. Polym. 89(1), 177-184. DOI: 10.1016/j.carbpol.2012.02.068

Xu W.T., Huang K.I., Guo F., Qu W., Yang J.J., Liang Z.H., Luo Y.B., 2007. Postharvest grejpfrut seed extract and chitosan treatments of table grapes to control Botrytis cinerea. Postharvest Biol. Technol. 46, 86-94. DOI: 10.1016/j.postharvbio.2007.03.019

Yang L., Wen K.-S., Ruan X., Zhao Y.-X., Wei F., Wang Q., 2018. Response of plant secondary metabolites to environmental factors. Molecules 23, 762. DOI: 10.3390/molecules23040762

Yusuf A.J., Abdullahi M.I., Aleku G.A., Ibrahim I.A.A., Alebiosu C.O., Yahaya M., Adamu H.W., Sanusi A., Mailafiya M., Abubakar H., 2018. Antimicrobial activity of stigmasterol from the steam bark of Neocarya macrophylla. J. Med. Plants Econ. Dev. 2(1), 1-5. DOI: 10.4102/jomped.v2i1.38

Zacharias C.A., Sheppard D.C., 2019. The role of Aspergillus fumigatus polysaccharides in host-pathogen interactions. Cur. Opin. Microbiol. 52, 22-26. DOI: 10.1016/j.mib.2019.04.006

Zarnowski R., Suzuki Y., 2004. Expedient Soxhlet extraction of resorcinolic lipids from wheat grains. J. Food Compos. Anal. 1, 649-664.

Zhang J., Abel-Mageed W.M., Liu M., Huang P., He W., Li L., Song F., Dai H., Liu X., Liang J., Zhang L., 2013. Caesanines A-D, New cassane diterpenes with unprecedented bridze from Caesalpinia sappan. Org. Lett. 15(18), 4726-4729. DOI: 10.1021/ol402058z

Zhou H., Liu C., 2006. Microwave assisted extraction of solanesol from tobacco leaves. J. Chromatogr. A. 1129, 135-139. DOI: 10.1016/j.chroma.2006.07.083

Zychowicz C., Cieplińska T., 2002. Czy polskie probiotyki wywodza się z Olsztyna?. Pediatr. Współcz. 4(1), 89. 


\section{Spis tabel}

Tabela 1. Schemat kolejności badań nad roślinami leczniczymi [opracowano na podstawie: Farnsworth i in. 1985].

Tabela 2. Rozpuszczalniki stosowane do procesu ekstrakcji związków bioaktywnych [opracowano na podstawie: Azmir i in. 2013].

Tabela 3. Zastosowanie techniki ekstrakcji w aparacie Soxhleta do otrzymania wyciągów o właściwościach przeciwdrobnoustrojowych

Tabela 4. Wykorzystanie ekstrakcji wspomaganej ultradźwiękami do otrzymania wyciągów o przeciwdrobnoustrojowych właściwościach.

Tabela 5. Wykorzystanie ekstrakcji wspomaganej mikrofalami do otrzymania wyciągów o przeciwdrobnoustrojowych właściwościach.

Tabela 6. Zastosowanie techniki ekstrakcji cieczą pod ciśnieniem do otrzymania wyciągów o właściwościach przeciwdrobnoustrojowych...

Tabela 7. Zastosowanie techniki ekstrakcji płynem nadkrytycznym do otrzymania wyciągów z roślin o właściwościach przeciwdrobnoustrojowych.

Tabela 8. Porównanie wydajności różnych technik ekstrakcji.

Tabela 9. Zastosowanie wybranych metod pomiaru właściwości antyoksydacyjnych wyciągów z roślin o właściwościach przeciwdrobnoustrojowych

Tabela 10. Podział związków fenolowych i ich przykłady [opracowano na podstawie: Kusznierewicz 2017].

Tabela 11. Podział terpenoidów i ich przykłady [opracowano na podstawie:

Kabera i in. 2014].

Tabela 12. Podział metabolitów wtórnych zawierających siarkę [opracowano nanpodstawie:

Omar i Al-Wabel 2010, St-Gelais i in. 2015, Kusznierewicz 2017].

Tabela 13. Przykłady substancji i związków roślinnych działających na chorobotwórcze grzyby drożdżoidalne.

Tabela 14. Ekstrakty i olejki roślinne hamujące wzrost wybranych szczepów chorobotwórczych

Tabela 15. Preparaty roślinne hamujące wzrost szczepów H. pylori. .73 
Tabela 16. Aktywność przeciwdrobnoustrojowa ekstraktów z roślin przeciw patogenom przenoszonym drogą płciową.

Tabela 17. Lista szczepów bakterii fermentacji mlekowej o udokumentowanych właściwościach probiotycznych [opracowano na podstawie: Gawęcki i Libudzisz 2006, Nowak i in. 2010].

Tabela 18. Farmaceutyczne preparaty roślinne wzmagające namnażanie wybra nych szczepów bakterii z rodzaju Lactobacillus, Bifidobacterium i Streptococcus [opracowano na podstawie: Hołderna-Kędzia i Kędzia 2012].

Tabela 19. Farmaceutyczne preparaty roślinne obojętne wobec szczepów bakterii z rodzaju Lactobacillus, Bifidobacterium i Streptococcus [opracowano na podstawie: Hołderna-Kędzia i Kędzia 2012]

Tabela 20. Preparaty roślinne hamujące wzrost szczepów bakterii z rodzaju Lactobacillus, Bifidobacterium i Streptococcus [opracowano na podstawie: Hołderna-Kędzia i Kędzia 2012]

Tabela 21. Preparaty roślinne obojętne (0), hamujące (-) lub aktywujące $(+)$ wzrost szczepu drożdży probiotycznych S. cerevisiae (boulardii) SB 48-MYA-796 [opracowano na podstawie: Hołderna-Kędzia i Kędzia 2012]

Tabela 22. Wykaz najbardziej znanych patogenów grzybowych roślin i preparatów produkowanych z roślin, których działanie przeciwdrobnoustrojowe zostało przebadane. 